\author{
UNIVERSIDADE DE SÃO PAULO \\ FACULDADE DE ECONOMIA, ADMINSTRAÇÃO E \\ CONTABILIDADE \\ DEPARTAMENTO DE ECONOMIA \\ PROGRAMA DE PÓS-GRADUAÇÃO EM ECONOMIA
}

ENSAIOS EM POLÍTICA FISCAL PARA PAÍSES

EMERGENTES

Raí da Silva Chicoli

Orientador: Prof. Dr. Siegfried Bender

São Paulo

2020 
Prof. Dr. Vahan Agopyan

Reitor da Universidade de São Paulo

Prof. Dr. Fábio Frezatti

Diretor da Faculdade de Economia, Administração e Contabilidade

Prof. Dr. José Carlos de Souza Santos

Chefe do Departamento de Economia

Prof. Dr. Ariaster Baumgratz Chimeli

Coordenador do Programa de Pós-Graduação em Economia 
Raí da Silva Chicoli

\section{ENSAIOS EM POLIITICA FISCAL PARA PAÍSES EMERGENTES}

Tese apresentada ao Programa de PósGraduação em Economia do Departamento de Economia da Faculdade de Economia, Administração e Contabilidade da Universidade de São Paulo, como requisito parcial para obtenção do título de Doutor em Ciências.

Área de Concentração: Teoria Econômica

Orientador: Prof. Dr. Siegfried Bender

Versão Corrigida

São Paulo

2020 


\section{FICHA CATALOGRÁFICA}

Elaborada pela Seção de Processamento Técnico do SBD/FEA/USP

Chicoli, Raí da Silva.

Ensaios em Política Fiscal para Países Emergentes / Raí da Silva Chicoli. - São Paulo, 2020. $179 \mathrm{p}$.

Tese (Doutorado) - Universidade de São Paulo, 2020.

Orientador: Siegfried Bender.

1. Finanças públicas. 2. Política fiscal. 3. Dívida Pública. I. Universidade de São Paulo. Faculdade de Economia, Administração e Contabilidade. II. Título. 
Aos meus pais, Vicente e Leila, por todo apoio e auxílio que sempre me deram e por terem sido os melhores pais que um filho poderia ter. 



\section{AGRADECIMENTOS}

Aos meus pais, Vicente e Leila, por terem sido sempre presentes em minha vida e terem me dado todo o apoio para a conclusão desta tese.

Aos meus familiares queridos, Rafael, Juliana, Bianca e Milka por toda a companhia.

À Ariane Kotarski pelo apoio, paciência, incentivo, inspiração e, principalmente, por ter tornado uma pessoa melhor e mais feliz.

À Faculdade de Economia e Administração da Universidade de São Paulo por todo conhecimento transmitido.

Ao Conselho Nacional de Desenvolvimento Científico e Tecnológico (CNPq), pela concessão de bolsa de doutorado e pelo apoio financeiro para a realização desta pesquisa.

Ao coordenador do curso de pós-graduação em Ciências Econômicas.

Aos meus professores de graduação, mestrado e doutorado por todo 0 conhecimento compartilhado.

Ao Prof. Dr. Siegfried Bender, por sua orientação, paciência, incentivo que elevaram o nível de qualidade e tornaram possível a conclusão desta tese.

Aos Profs. Drs. Fabiana Fontes Rocha e Marcos Yamada Nakaguma pelas críticas e sugestões feitas ao longo de todo processo de construção deste trabalho, sendo primordiais para a construção desta tese.

Ao Prof. Dr Alexandre Schwartsman pela participação na banca de defesa e pelas sugestões de melhorias neste trabalho.

Ao PAPO Tesouro, em especial a Maurício Leister, Daniel Cunha e Lucas Leite pelo auxílio e discussões que tornaram este trabalho melhor.

À turma do mestrado no IPE-USP de 2013, em especial a Antônio Neto, Daniel Dantas, Pedro Schneider, Matheus Rosignoli e Fábio Serrano.

Aos amigos de longa data, Bruno Palialol, Danilo Paula, Lucas Simon e Vitor Camargo.

A todos aqueles que participaram direta e indiretamente na realização desta dissertação. 



\section{RESUMO}

Nesta tese buscamos abordar distintos assuntos sobre política fiscal, sempre tendo como foco o Brasil ou o grupo de países emergentes. No primeiro ensaio, medimos o impulso fiscal do Brasil para o período de 2002 a 2018 por diferentes metodologias. Como resultado, encontramos que os resultados pouco variam entre as distintas métricas encontradas na literatura; entretanto há uma diferença significativa para alguns anos dependendo da forma de medir 0 produto potencial. Além disso, observamos que a deterioração recente das contas públicas brasileira está associada à uma política fiscal expansionista, sendo que, nos últimos dois anos de análise (2017 e 2018), houve uma aparente mudança com impulsos fiscais contracionistas. No segundo ensaio, abordamos o tema de fadiga fiscal e limite de endividamento para um conjunto de 19 países emergentes para o período de 2003 a 2016 utilizando um modelo teórico desenvolvido por Ghosh et al. (2013). Como resultado, encontramos que a hipótese de fadiga fiscal foi confirmada e corroborada por diversos testes de robustez. Para o limite de endividamento, combinamos o resultado estimado para a função de reação fiscal e o diferencial entre taxa de juros e crescimento econômico. Para o caso determinista, os resultados indicaram níveis de endividamento máximo inferiores aos observados para países desenvolvidos, mas com um espaço fiscal elevado para todos os países. Entretanto, para o caso estocástico, os resultados de Brasil e Croácia indicaram um espaço fiscal baixo, mostrando a necessidade destes países realizarem ajustes nos próximos anos que possibilitem a redução no seu nível de endividamento. No terceiro ensaio, procuramos medir o efeito do endividamento público sobre o crescimento econômico partindo de regressões com variáveis instrumentais via a metodologia de Métodos Generalizados de Momento para 36 países emergentes no período de 1990 a 2017. Como resultado, encontramos evidências de não linearidade entre crescimento e endividamento no formato de $U$ invertido, sendo que o ponto de inversão fica entre $40-60 \%$ do PIB. Os resultados são válidos para os crescimentos de um e cinco anos à frente e se mostraram robustos a uma série de testes de robustez realizados. Além disso, observamos que países com maior nível de democracia possuem ponto de reversão em níveis superiores de endividamento em comparação a países com menor nível de democracia. Já em outro exercício, encontramos que quando o investimento público é baixo, os resultados de não linearidade e do ponto de reversão se mantiveram, mas para os casos em que o investimento público é alto, um maior endividamento leva a maior crescimento.

Palavras-chave: Finanças Públicas, Política Fiscal, Dívida Pública. 



\begin{abstract}
In this doctoral dissertation we seek to address different fiscal policy issues, always focusing on Brazil or the group of emerging countries. In the first essay, we measured Brazil's fiscal impulse over the 2002-2018 period through different methodologies. As a result, we found that results had little changes among the different metrics found in the literature; however, there is a significant difference for some years depending on how to measure potential output. Moreover, we noted that the recent deterioration of the Brazilian public accounts was associated with an expansionary fiscal policy, and in the last two years of analysis (2017 and 2018) there has been an apparent change with contractionary fiscal impulses. In the second essay, we addressed the topic of fiscal fatigue and debt limit for a set of 19 emerging countries over the period 2003-2016 using a theoretical model developed by Ghosh et al. (2013). As a result, we found that the hypothesis of fiscal fatigue was confirmed and corroborated by several robustness tests. For the debt limit, we combined the estimated result for the fiscal reaction function and the differential between interest rate and economic growth. For the deterministic case, the results indicated maximum debt levels below those observed for developed countries, but with a high fiscal space for all countries. However, for the stochastic case, the results from Brazil and Croatia indicated a low fiscal space, showing that these countries must make fiscal adjustments in the coming years to reduce their debt levels. In the third essay, we sought to measure the effect of public debt on economic growth from regressions with instrumental variables via the Generalized Momentum Methods methodology for 36 emerging countries from 1990 to 2017. As a result, we found evidence of nonlinearity between growth and debt as a U-shaped relation, with the reversion point being between $40-60 \%$ of GDP. The results were valid for growth one and five years ahead and proved robust to a series of robustness tests performed. In addition, we note that countries with a higher level of democracy have a reversal point in higher levels of debt compared to countries with a lower level of democracy. In another exercise, we found that when public investment is low, the nonlinearity and reversal point results were maintained, but for cases where public investment is high, higher indebtedness leads to higher growth.
\end{abstract}

Keywords: Public Finance, Fiscal Policy, Public Debt. 



\section{ÍNDICE DE GRÁFICOS}

Figura 1: Superávit primário do setor público consolidado acumulado em 12 meses (em \% do PIB).................................................................. 18

Figura 2: Dívida Bruta do Governo Geral (em \% do PIB) ............................... 19

Figura 3: Média e mediana de endividamento bruto de países emergentes (em $\%$ do PIB) .................................................................................. 20

Figura 4: Resultado primário oficial e primário excluindo as operações one-off e temporárias (em \% do PIB) ............................................................... 41

Figura 5: Hiato do Produto pelo filtro HP e pela função de produção...............42 42

Figura 6: Resultados primários por diferentes métricas (em \% do PIB) .......... 47

Figura 7: Determinação do Limite de dívida ............................................6 66

Figura 10: Função de reação fiscal e diferenciais de juros para o caso brasileiro 


\section{ÍNDICE DE TABELAS}

Tabela 1: Elasticidade da Arrecadação em relação ao PIB............................... 44

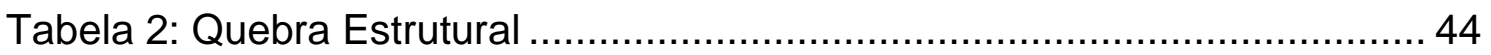

Tabela 3: Resultado da elasticidade entre quebras estruturais ....................... 45

Tabela 4: Elasticidade do Grupo de Impostos e Contribuições em relação ao

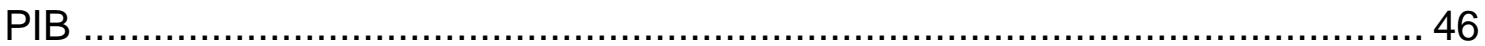

Tabela 5: Resultado de Impulso Fiscal para filtro HP (em \% do PIB) .............. 48

Tabela 6: Resultado de Impulso Fiscal para Função de Produção (em \% do

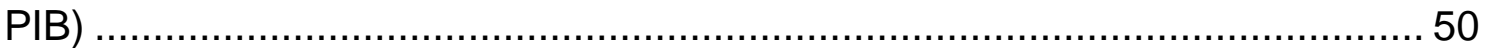

Tabela 7: Decomposição da diferença entre o impulso fiscal pela métrica do primário oficial e a diferença entre a média das métricas obtidos por meio do

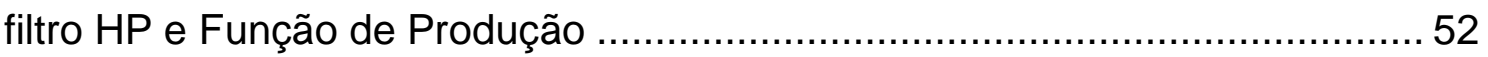

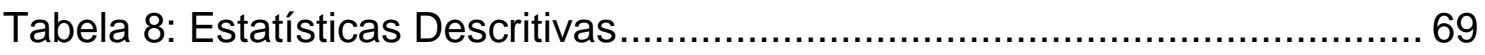

Tabela 9: Estimação da Função de Reação Fiscal ....................................... 72

Tabela 10: Testes de robustez para a estimação da função de reação fiscal .. 75

Tabela 11: Estimação da função de reação fiscal com o resultado primário

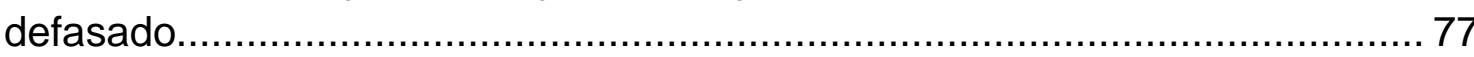

Tabela 12: Estimação da Função de Reação Fiscal para endividamento baixo-

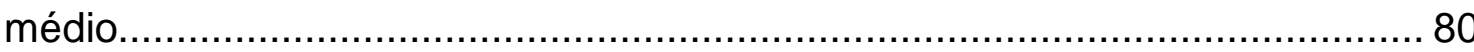

Tabela 13: Estimação da Função de Reação Fiscal para endividamento médio-

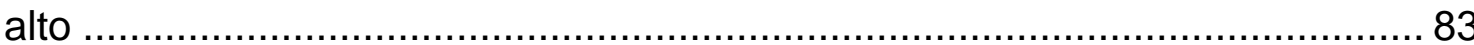

Tabela 14: Estimação da função de reação fiscal por variáveis instrumentais via

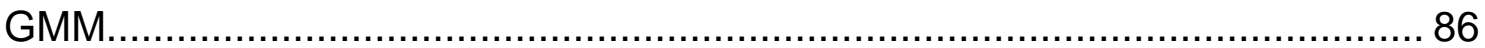

Tabela 15: Diferencial entre taxa de juros e crescimento econômico (em \%)

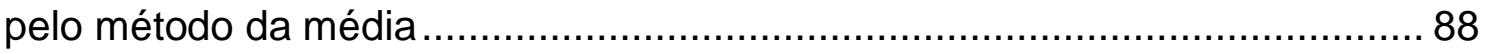

Tabela 16: Espaço Fiscal e Limite de Endividamento para o caso determinista para o diferencial pela média (em \% do PIB) …......................................... 90 Tabela 17: Espaço Fiscal e Limite de Endividamento para o caso estocástico para o diferencial pela média (em \% do PIB) ……...................................... 92 Tabela 18: Diferencial entre taxa de juros e crescimento econômico (em \%) pelo método do juros estrutural e do crescimento potencial............................. 94 Tabela 19: Espaço Fiscal e Limite de Endividamento para o caso determinista pelo método do juros estrutural e do crescimento potencial (em \% do PIB) .... 95 Tabela 20: Espaço Fiscal e Limite de Endividamento para o caso estocástico pelo método do juro estrutural e do crescimento potencial (em \% do PIB) ...... 96 Tabela 21: Estimação da taxa de crescimento para o ano seguinte por efeitos fixos

Tabela 22: Estimação da taxa de crescimento para o ano seguinte por variáveis instrumentais via GMM.

Tabela 23: Estimação da taxa de crescimento para o ano seguinte por variáveis instrumentais via GMM. 120

Tabela 24: Estimação da taxa de crescimento para cinco anos por efeitos fixos 
Tabela 25: Estimação da taxa de crescimento para cinco anos por variáveis instrumentais via GMM...

Tabela 26: Estimação da taxa de crescimento para cinco anos por variáveis

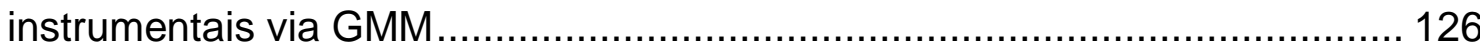

Tabela 27: Estimação com democracia.................................................. 128

Tabela 28: Estimação com crédito privado como variável de controle ........... 130

Tabela 29: Estimação com interação de dummy de investimentos................. 133

Tabela 30: Estimação excluindo os outliers para crescimento anual .............. 136

Tabela 31: Estimação excluindo os outliers para crescimento de cinco anos 138

Tabela 32: Estimação com persistência no crescimento............................... 142

Tabela 33: Diferencial entre taxa de juros básica e crescimento econômico pelo

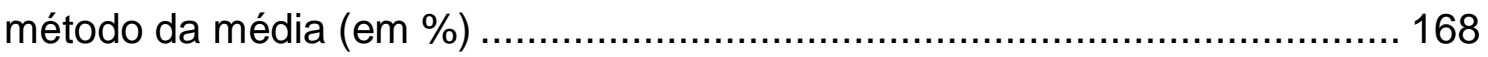

Tabela 34: Espaço Fiscal e Limite de Endividamento para o caso determinista pelo método da média (em \% do PIB) ......................................................... 169

Tabela 35: Espaço Fiscal e Limite de Endividamento para o caso estocástico pelo método da média (em \% do PIB) .................................................. 170

Tabela 36: Diferencial entre taxa de juros básica e crescimento econômico pelo método de juros estrutural e crescimento potencial (em \%) ........................... 171 Tabela 37: Espaço Fiscal e Limite de Endividamento para o caso determinista pelo método de juros estrutural e crescimento potencial (em \% do PIB) ....... 172 Tabela 38: Espaço Fiscal e Limite de Endividamento para o caso estocástico pelo método de juros estrutural e crescimento potencial (em \% do PIB) ....... 173 Tabela 39: Estimação da taxa de crescimento anual para o endividamento externo

Tabela 40: Estimação da taxa de crescimento de cinco anos para o endividamento externo 


\section{Sumário}

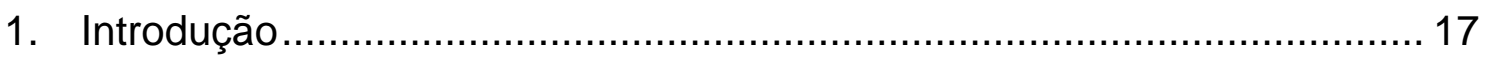

2. Cálculo do Impulso Fiscal da Economia Brasileira sob Diferentes

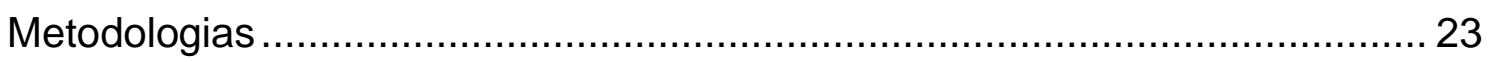

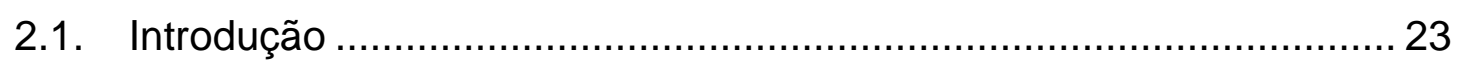

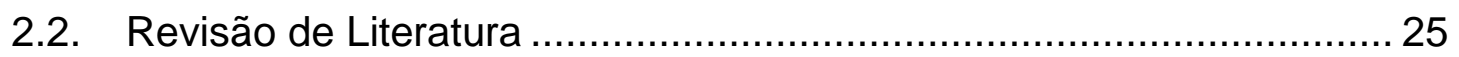

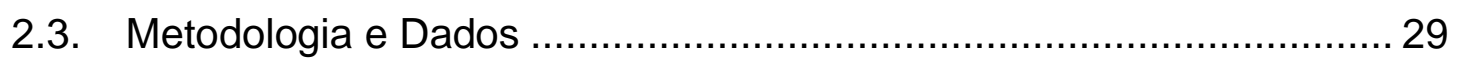

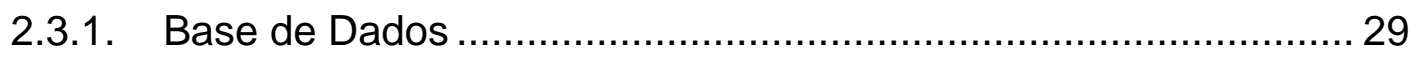

2.3.2. Metodologia para cálculo de impulso fiscal............................... 30

2.3.2.1. Metodologia mais antigas para cálculo de impulso fiscal ........... 31

2.3.2.2. Metodologia mais novas para cálculo de impulso fiscal ............ 32

2.3.3. Cálculo para retirada dos efeitos de outros ciclos e fatores.......... 39

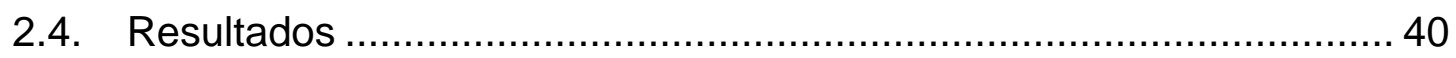

2.4.1. Retirada das operações one-off e temporárias.............................. 40

2.4.2. Cálculo do produto potencial .................................................. 42

2.4.3. Resultados da Elasticidade ..................................................... 43

2.4.4. Resultado Primário Estrutural .................................................. 46

2.4.5. Resultados do Impulso Fiscal .................................................. 47

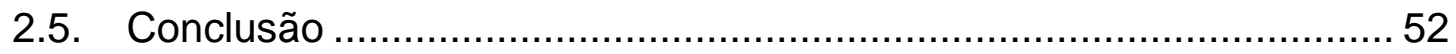

3. Estimação do nível máximo de endividamento para países emergentes .. 55

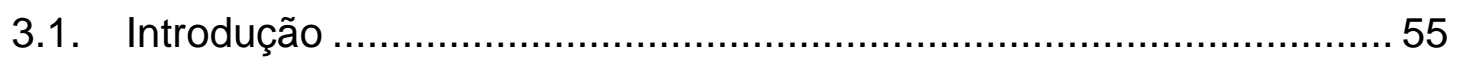

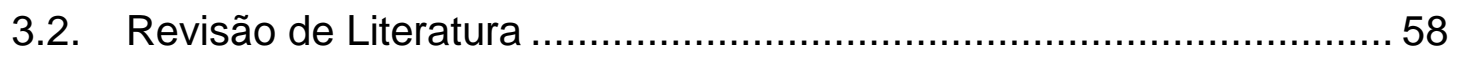

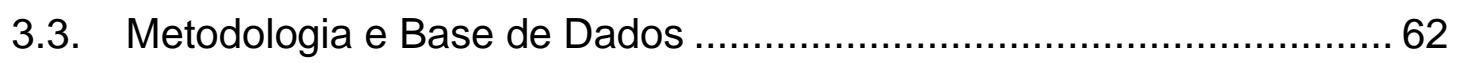

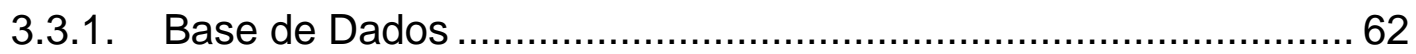

3.3.2. Arcabouço Teórico e Metodologia Empírica ................................. 63

3.3.3. Cálculo do Diferencial entre Juros e Crescimento Econômico ..... 69

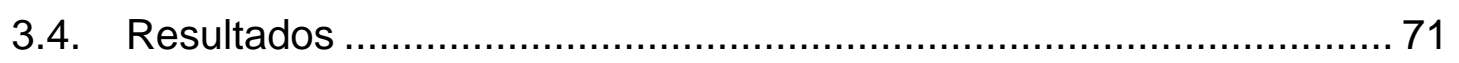

3.4.1. Estimação da Função de Reação Fiscal ................................... 71

3.4.2. Robustez da função de reação fiscal, da hipótese de homogeneidade e problema de causalidade reversa ............................... 74

3.4.3. Intervalo de Confiança da redução na resposta marginal e do ponto

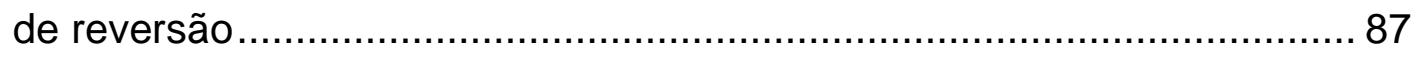

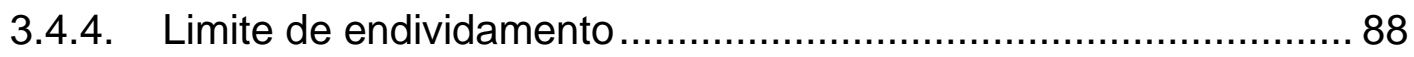


3.5. Conclusão

4. Efeito não linear do endividamento público sobre o crescimento econômico: Uma análise para países emergentes ............................................................ 99

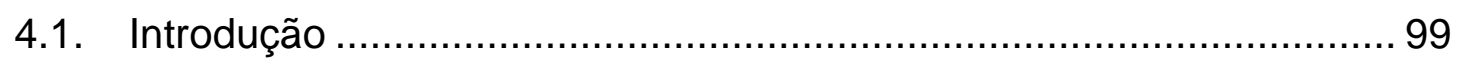

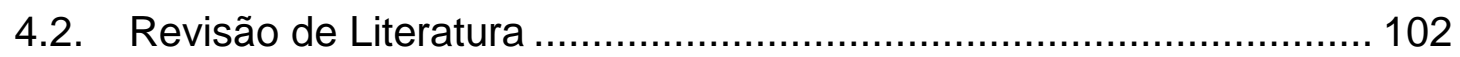

4.3. Metodologia e Base de Dados ......................................................... 108

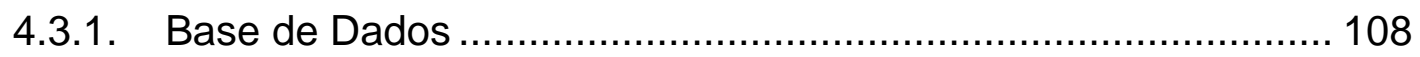

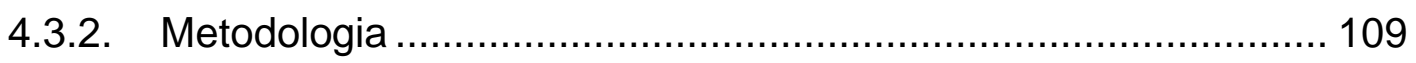

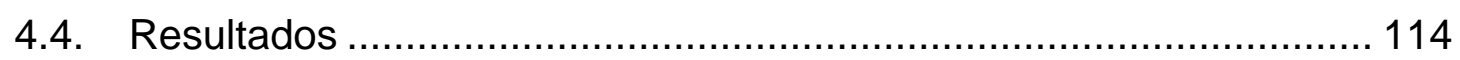

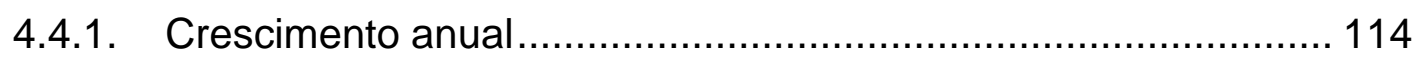

4.4.2. Crescimento de cinco anos................................................. 122

4.4.3. Possíveis variáveis relevantes omitidas .................................. 127

4.4.4. Endividamento e investimento público.................................... 131

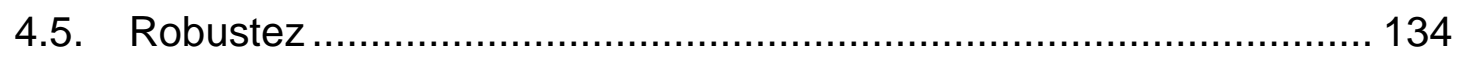

4.5.1. Remoção de outliers da amostra ............................................ 134

4.5.2. Forma polinomial da função de endividamento ......................... 139

4.5.3. Crescimento de 10 anos e crescimento de 5 anos sem

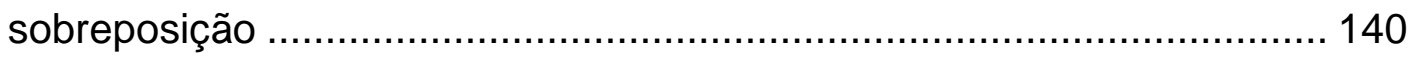

4.5.4. Persistência do crescimento e variação da dívida ...................... 140

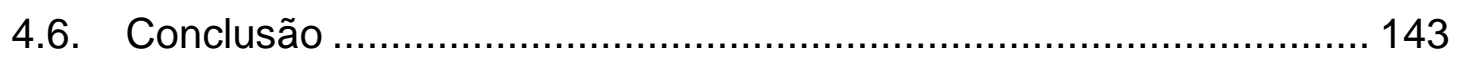

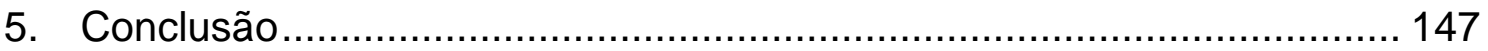

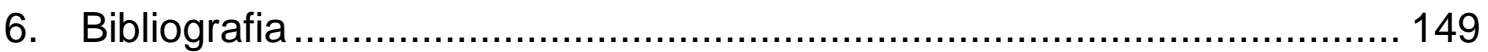

ANEXO

A.1. Derivação do Limite de dívida para o caso estocástico ........................ 163

A.2. Limite de endividamento com juros de mercado................................ 167

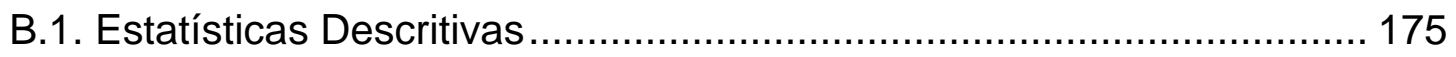

B.2. Regressão para o endividamento externo ………............................. 177 


\section{Introdução}

A adoção, em janeiro de 1999, do regime de câmbio flutuante, aliado ao regime de metas de inflação, adotado em junho do mesmo ano e, por fim, com a sanção, em maio de 2000, da Lei de Responsabilidade Fiscal, formaram o tripé de política monetária e fiscal que guiou a política macroeconômica do país nos últimos anos.

No campo fiscal, a adoção da Lei de Responsabilidade Fiscal (LRF) foi de suma importância para a recuperação da credibilidade da política fiscal no Brasil com a maior previsibilidade orçamentária, o planejamento de longo prazo e, principalmente, com a adoção de superávits primários que auxiliaram no controle do endividamento público do país.

Neste ínterim, a política fiscal passou por diversos solavancos e problemas em sua condução que levaram a atual situação fiscal observada no país. O primeiro grande desafio fiscal enfrentado pelo país pós LRF foi a eleição presidencial de 2002. Com o risco Lula, que era, na época, um candidato com postura econômica radical e favorito na corrida presidencial, houve uma forte desvalorização do dólar em um curto espaço de tempo e, como grande parte da dívida nacional estava indexada ao dólar, houve um grande aumento no endividamento do país.

Entretanto, com a carta ao povo brasileiro, ainda na corrida presidencial, e adoção de uma política econômica similar ao de seu antecessor, com uma política ainda mais ortodoxa no campo fiscal com aumento nas metas de superávits primários, o presidente eleito conseguiu reverter o aumento na aversão ao risco no país e aumentar a credibilidade fiscal.

Nos anos seguintes, o país obteve elevados resultados primários e foram realizadas alterações na composição da dívida pública que propiciaram uma redução consistente do endividamento do país que culminaram com a obtenção do grau de investimento pelas agências de risco.

Esse cenário perdurou até a crise de 2008, quando o governo decidiu, por meio de uma política fiscal anticíclica, retirar o país da recessão econômica 
de 2009. Com a eleição da presidente Dilma em 2010 e o crescimento econômico modesto nos anos posteriores, o governo decidiu reforçar a aposta na política fiscal adotada na crise que consistia de: desonerações tributárias, ampliação nos empréstimos de bancos oficiais, capitalizados por aportes do Tesouro Nacional, adoção de operações fiscais pouco usuais (como as operações de contabilidade criativa) sucessivos parcelamentos de débitos de empresas com a Receita Federal, aumento na dependência de receitas extraordinárias como concessões e dividendos de estatais para o cumprimento da meta fiscal, as pedaladas fiscais e o aumento contínuo dos gastos públicos. Todos estes fatores levaram a uma grande deterioração da política fiscal no país, chegando à situação de insustentabilidade da dívida pública brasileira ${ }^{1}$, como apresentado por Chicoli (2015).

Figura 1: Superávit primário do setor público consolidado acumulado em 12 meses (em \% do PIB)

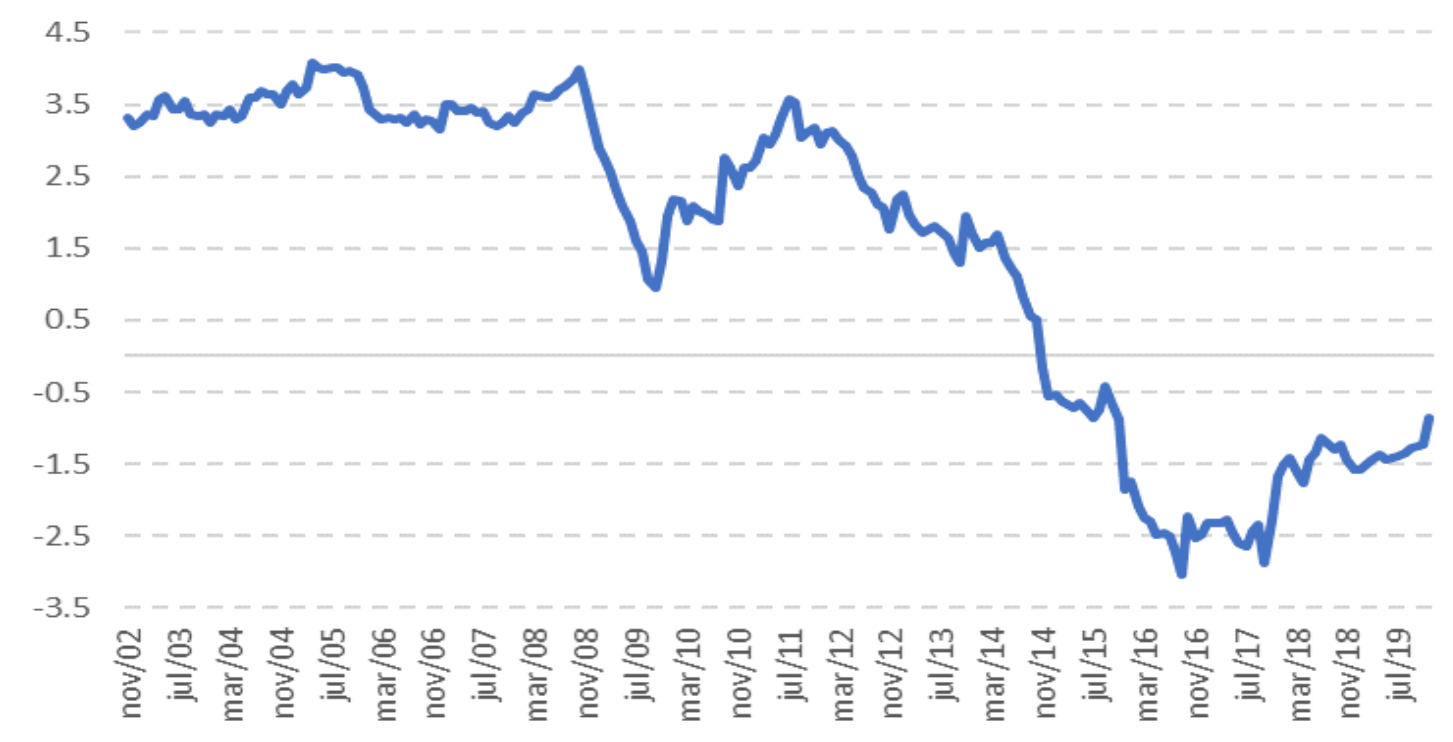

Fonte: Banco Central do Brasil

A Figura 1 representa bem o período descrito anteriormente. Após um longo período de elevados superávits primários, houve uma redução no ano de 2009, associado à recessão econômica deste ano e posterior recuperação em 2010. Entretanto, com diversas alterações do lado das receitas e com o constante aumento de gastos, observou-se uma contínua deterioração nas

\footnotetext{
${ }^{1}$ Neste conceito de insustentabilidade, assume-se que na atual trajetória do superávit primário, a dívida do país se tornará insustentável.
} 
contas públicas a partir de 2012, fato este corroborado pelos seguidos impulsos fiscais positivos após este período, fazendo com que o país apresentasse 0 primeiro déficit primário da série histórica em 2014. Deste ano em diante, o país não conseguiu apresentar superávits primários, o que acabou piorando muito a dinâmica da dívida pública, como é possível observar na Figura 2.

Figura 2: Dívida Bruta do Governo Geral (em \% do PIB)

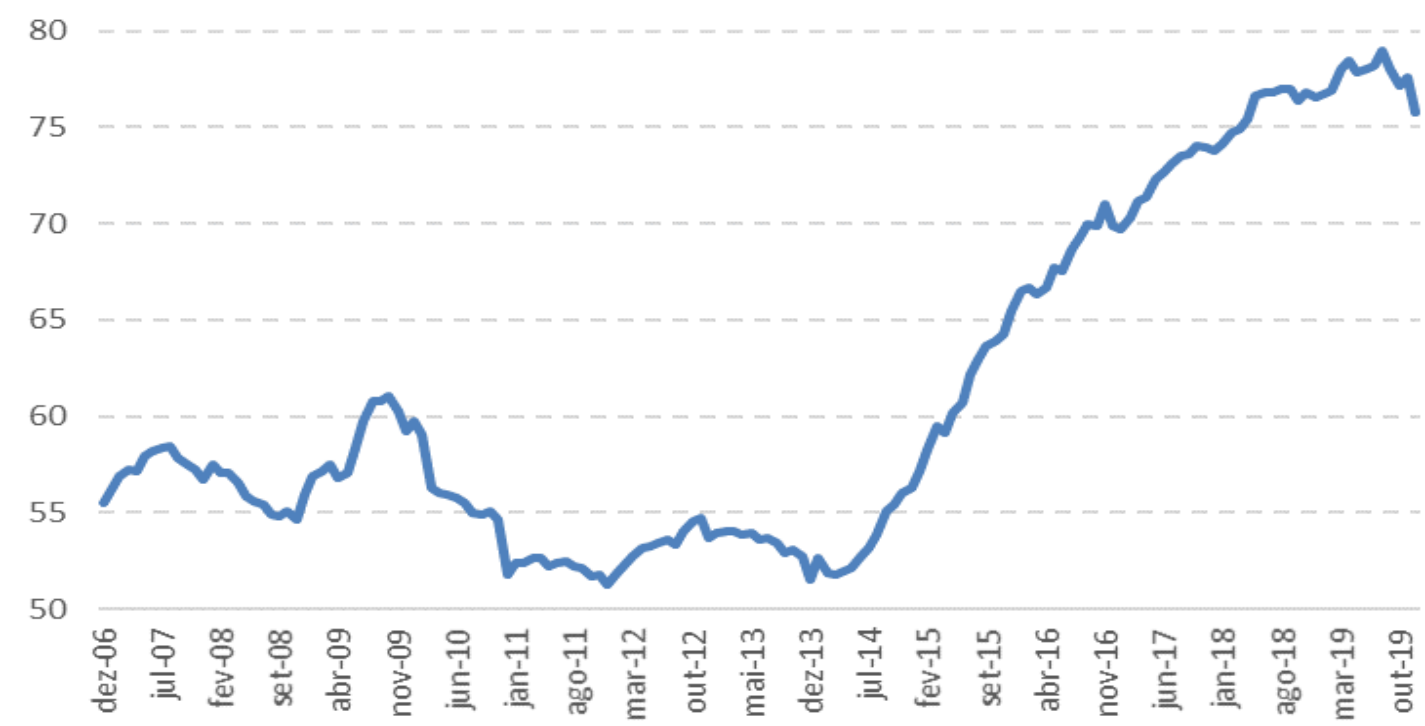

Fonte: Banco Central do Brasil

A piora nos resultados primários, associado à taxa de juros real superior ao crescimento real do PIB por todo período analisado ${ }^{2}$, foram os principais responsáveis pela alteração na dinâmica do endividamento bruto do país, como pode ser observado no gráfico acima ${ }^{3}$. Com isso, o Brasil começou a apresentar níveis de endividamento que podem ter impactos negativos sobre o crescimento econômico como apresentado por Reinhart e Rogoff (2010), Kumar e Woo (2010), Cecchetti et al. (2011b) e Baum et al. (2013). Além disso, a trajetória atual do endividamento e seu nível elevado faz com que haja uma probabilidade elevada do endividamento não ser sustentável. Com isso, os investidores não comprarão mais títulos, tornando inviável a emissão de dívida, obrigando o

\footnotetext{
${ }^{2}$ Nesta análise, seguimos a dinâmica da dívida pública dada por Carvalho et al. (2009): $\Delta B=$ $D_{t}+\frac{r_{t}-\gamma_{t}}{1+\gamma_{t}} B_{t}$, em que $B_{t}$ é estoque de dívida, $r_{t}$ é o juros real, $\gamma_{t}$ é o crescimento real do produto e $D_{t}$ é o déficit primário.

${ }^{3}$ Auxiliou, também, na deterioração da dívida bruta, os empréstimos do Tesouro Nacional ao BNDES que apesar de não afetarem a dívida líquida, tiveram importante impacto na dívida bruta.
} 
governo a se financiar via emissão de moeda. Todo este processo pode levar a pressões inflacionárias, conforme apresentado por Sargent e Wallace (1981).

Portanto, a atual trajetória de endividamento leva ao questionamento de qual será o nível máximo de razão dívida/PIB que o país pode alcançar mantendo a hipótese de sustentabilidade. Ghosh et al. (2013) e Fournier e Fall (2015a) buscam encontrar este nível para países desenvolvidos.

Entretanto, é importante notar que a deterioração fiscal recente não é uma exclusividade do Brasil. Após a crise de 2008, diversos países emergentes apresentaram aumento no seu nível de endividamento bruto como é possível observar na Figura 3:

Figura 3: Média e mediana de endividamento bruto de países emergentes (em \% do PIB)

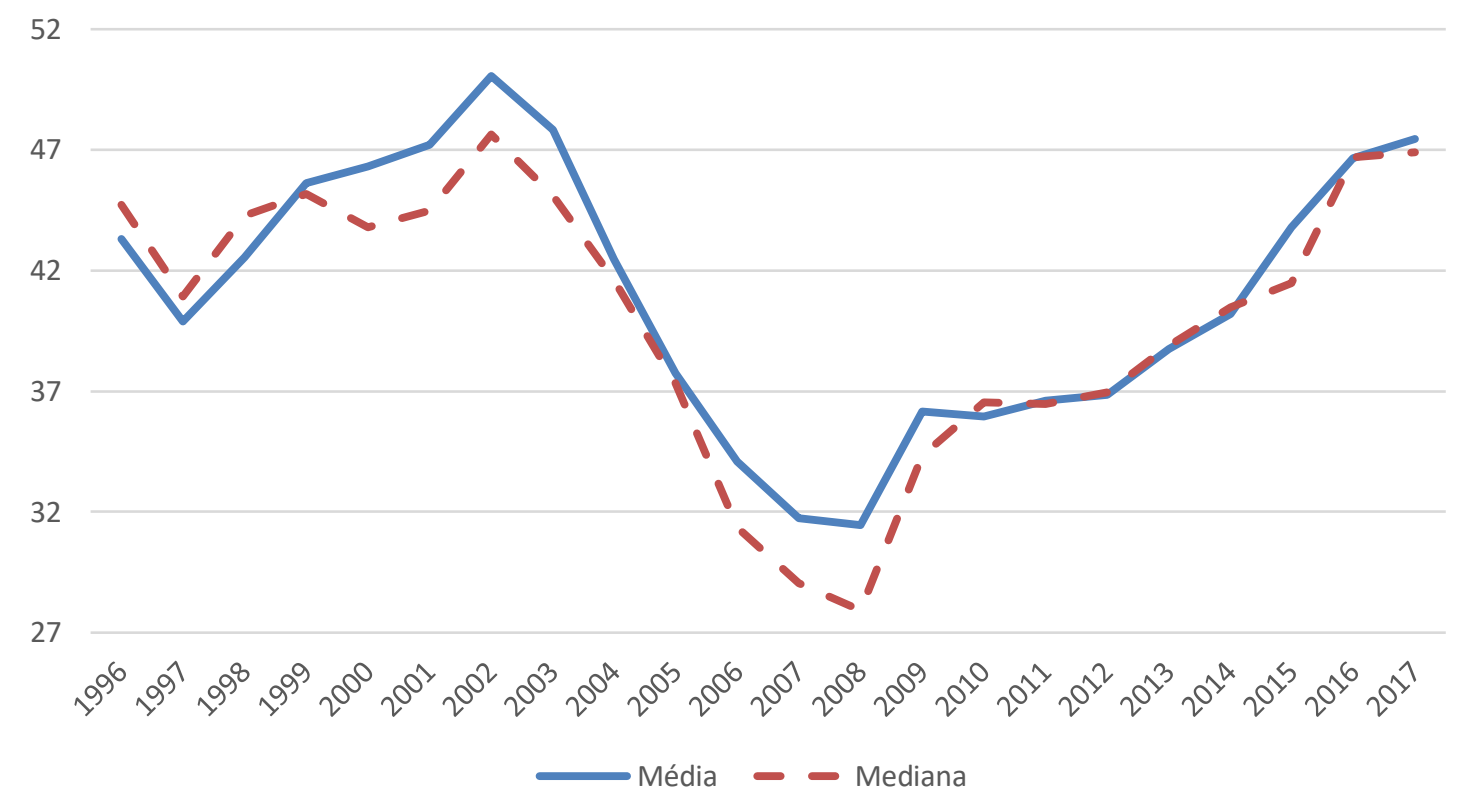

Fonte: Fundo Monetário Internacional

Para o grupo de 38 países emergentes selecionados de acordo com o Fiscal Monitor do FMI (2017), observamos que há movimentos na tendência claros. De 1996 a 2002 há um aumento no nível de endividamento dos países e, de 2002 a 2008 há uma redução contínua do nível endividamento deste grupo de países, sendo que a média do endividamento chegou a níveis próximos a $31 \%$ do PIB. Entretanto, com o advento da crise financeira, houve uma redução na taxa de crescimento desse grupo de países e uma deterioração nas finanças públicas, fazendo com que o endividamento apresentasse um crescimento 
quase contínuo até 2017, quando média e mediana alcançaram valores superiores aos do início dos anos 2000.

Portanto, dada a atual situação fiscal do Brasil e dos países emergentes, esta tese terá como objetivo analisar o impulso fiscal no Brasil por meio de diversas metodologias e verificar se seus resultados diferem muito; estimar 0 nível máximo de endividamento do Brasil e de outros emergentes por meio do modelo de Ghosh et al (2013) e, por fim, analisar se o endividamento possui efeito sobre a taxa de crescimento e se este efeito é não linear para um grupo de países emergentes.

Outra contribuição que esta tese busca obter é auxiliar na discussão de regras fiscais que poderiam ser adotadas pelos países. Em cada capítulo desta tese algum tipo de regra fiscal está diretamente ou indiretamente associada. No capítulo 2 tratamos sobre o assunto de primário estrutural para o Brasil, que já uma métrica utilizada em outros países. No capítulo 3, tratamos sobre limite de endividamento para países emergentes, que dá parâmetros para países definirem suas regras de limite de dívida. Por fim, no capítulo 4 tratamos sobre o efeito do endividamento sobre o crescimento e como essa relação muda quando há investimento público, o que auxilia na discussão de como realizar ajustes que comprometam, o mínimo possível, investimentos.

Esta tese está dividida em cinco capítulos. Este primeiro capítulo introdutório. No segundo, é realizada uma análise da situação fiscal do Brasil por meio do cálculo do impulso fiscal dos últimos anos por diferentes metodologias, verificando seus diferentes resultados. No terceiro capítulo, utilizando o modelo de Ghosh et al. (2013), estimamos qual o nível máximo de endividamento do Brasil e de outros países emergentes. No quarto capítulo, verificamos se o endividamento possui efeito sobre a taxa de crescimento econômico e se este efeito é não linear para um grupo de países emergentes. Por fim, no quinto capítulo, apresentaremos uma conclusão com todos os resultados obtidos na tese. 


\section{Cálculo do Impulso Fiscal da Economia Brasileira sob Diferentes Metodologias}

\subsection{Introdução}

A métrica de impulso fiscal é comumente utilizada em diversos países para analisar como a política fiscal está atuando sobre a demanda agregada da economia. Esta métrica se mostra mais adequada do que a simples variação do resultado primário dos países pois ajusta o resultado primário ao ciclo da economia, como nas métricas mais antigas de impulso fiscal, e retira efeitos de outros fatores, como ciclos de commodities que afetam o resultado fiscal, igual a métricas mais recentes.

Como apresentado em Schinasi e Lutz (1991), as métricas de impulso fiscal são úteis por ao menos dois propósitos: i. Além de permitirem analisar a política fiscal do governo, são úteis para monitorar a performance das autoridades fiscais; ii. São úteis para comparações internacionais de mudanças na política fiscal, permitindo, por exemplo, verificar como a política fiscal se altera ao longo do tempo para países com acordos com organismos internacionais.

Philip e Janssen (2002) colocam o impulso fiscal como um componente muito útil no arcabouço de métricas que mensuram a posição fiscal estrutural, análises de tendências de impostos e gastos, e projeções de longo prazo para variáveis de inflação e crescimento do PIB. Vdovychenko (2018) ressalta a importância do impulso fiscal para projeções e análises do endividamento público. Além disso, o impulso fiscal permite verificar o impacto de ações discricionárias do governo, quantificando ações pró-cíclicas ou anticíclicas que não estão relacionadas ao desempenho da economia, se mostrando um importante subsídio à política monetária, como apresentado por Banco Central do Brasil (2011).

Entretanto, para o caso brasileiro, diferentes órgãos governamentais, como Secretaria de Política Econômica (SPE), Instituição Fiscal Independente (IFI), estudos do Instituto de Pesquisa Econômica Aplicada (IPEA) e Banco Central (2011), utilizam distintas metodologias, inclusive de produto potencial, 
para estimar o impulso fiscal, chegando a resultados diferentes, que, em alguns casos, podem levar a conclusões distintas sobre a posição fiscal do país em um determinado período.

Tendo isto em mente, buscaremos neste ensaio estimar o impulso fiscal na economia brasileira por meio de diferentes metodologias existentes na literatura. Desta forma, o ensaio contribui ao verificar se há uma diferença significativa no resultado para as diferentes métricas de impulso fiscal existentes e na forma de estimar o hiato do produto, via filtro HP e função de produção. Além disso, é realizada uma análise da política fiscal do governo federal desde 2002 que nos possibilita analisar os impulsos fiscais ao longo dos últimos anos.

Para verificarmos o impulso fiscal, iremos, primeiramente, realizar um ajuste nas receitas e despesas do governo, com base no ajuste realizado em Chicoli $(2015)^{4}$. Após este ajuste na série de dados, utilizaremos seis metodologias distintas que cobrem desde os métodos mais antigos utilizados pelo FMI e OCDE até os mais recentes, com algumas adaptações, destes mesmos organismos. Cada metodologia realizará ajustes no resultado primário pelo ciclo econômico e outros ciclos e, com isso, nos permitirá obter o resultado do impulso fiscal para o governo central ${ }^{5}$.

Para complementarmos a análise, além das diferentes metodologias para estimar o impulso fiscal, faremos uso de duas metodologias para o cálculo do produto potencial. A primeira segue a estimação por meio do filtro HP, que é uma metodologia mais simples e amplamente utilizada na literatura internacional. Entretanto, como há uma série de críticas com relação ao seu uso, dentre elas, revisões retroativas significativas com a adição de novos dados e falta de estrutura teórica. Para contornarmos estes problemas, utilizamos uma segunda metodologia por meio da função produção que possui maior estrutura econômica e é a mais recomendada na literatura internacional. Para o caso brasileiro, utilizamos as adaptações propostas por Souza-Junior e Caetano (2013) e Souza-Junior (2015).

\footnotetext{
${ }^{4}$ Serão realizados outros ajustes na série que serão melhor descritos na seção de metodologia. ${ }^{5}$ Para as métricas mais antigas, não haverá a obtenção do resultado estrutural, mas, diretamente, o impulso fiscal.
} 
Como resultado verificamos que, independente da metodologia de impulso fiscal adotada, os resultados obtidos são muito semelhantes, porém apresentam maior variação dependendo da metodologia utilizada para estimar o hiato do produto. A avaliação do impulso fiscal, por meio das metodologias apresentadas, se mostrou muito distinta em comparação à avaliação da diferença do resultado primário oficial, mostrando a importância destas métricas como um subsídio na avaliação correta da política fiscal. Além disso, parte importante do ajuste para alcançar o impulso fiscal está na retirada das operações one-off e temporárias.

Por fim, obtivemos evidências de que a partir de 2012 a 2016 o governo fez sucessivos impulsos fiscais positivos, com exceção do resultado negativo em 2015, fator este que auxiliou na deterioração recente das finanças públicas. E, nos anos de 2017 e 2018, o impulso fiscal foi negativo, indicando que, recentemente, pode ter ocorrido uma alteração na postura fiscal do governo federal.

A fim de sintetizar os objetivos e resultados deste estudo, o texto está dividido em cinco seções, contando esta breve introdução. Na seção 2, faremos uma revisão de literatura sobre impulsos fiscais. Na seção 3, apresentaremos as metodologias para o cálculo do impulso fiscal, a metodologia para o cálculo da elasticidade e os ajustes realizados nas séries de dados. Na seção 4 serão apresentados os resultados deste estudo. Por fim, será apresentada a conclusão na seção 5 .

\subsection{Revisão de Literatura}

Segundo Costantini (2015), a análise de orçamento ajustado ao ciclo se iniciou com programa orçamentário sueco de 1933, quando Gunnar Myrdal criou uma regra que permitia ao governo ajustar seu orçamento de acordo com o ciclo econômico.

Na década de 60, com o balanço de pleno emprego para a política fiscal americana, o superávit ou déficit de pleno emprego procurava mostrar qual seria a situação orçamentária do governo caso a economia estivesse operando sem a ociosidade dos fatores de produção. De Leeuw e Holloway (1982) 
apresentaram o resultado para a economia americana com base nesta metodologia no período de 1955 a 1981.

Na década de 80, o FMI adotou a medida do balanço ajustado neutro ao ciclo, em que é definido um ano base no qual o produto efetivo continua próximo ao seu nível potencial. Nesta metodologia, admite-se elasticidade unitária das receitas em relação ao produto efetivo e elasticidade unitária das despesas em relação ao produto potencial. Apesar da sua aparente simplicidade, esta técnica continua sendo utilizada em diversos trabalhos.

A OCDE também criou sua própria metodologia de balanço ciclicamente ajustado durante a década de 80 . Nesta metodologia, procura-se computar as elasticidades para receita e despesa e, com isso, obter os resultados de impulso fiscal.

Heller et al. (1986) realiza uma análise mais pormenorizada destas duas metodologias, mas não chega a nenhuma conclusão sobre qual metodologia é melhor, já que ambas possuem vantagens e desvantagens.

Blanchard (1990) realiza o ajuste com base em um conjunto mais amplo de variáveis. Com isso, estima as relações entre receita e despesa com o produto e outras variáveis que afetam o orçamento público.

Fedelino et al. (2009) e Escolano (2010) desenvolveram as metodologias mais comumente utilizadas na atualidade para ajustar o orçamento público ao nível de atividade, sendo que estas metodologias são, também, utilizadas por FMI e OCDE. Nestas metodologias, as despesas são ajustadas, unicamente, para os gastos relacionados ao desemprego, sendo que para o FMI a taxa de referência é aquela que não acelera a inflação (NAIRU) e para a OCDE, o nível de desemprego estrutural. Para as receitas, parte-se da proporcionalidade entre o quociente de receitas observadas e estruturais e, de outro, o produto efetivo e tendencial elevado pela elasticidade da receita. A diferença entre as metodologias utilizadas é que, na do FMI, utiliza-se a receita total e a elasticidade total, enquanto na metodologia da OCDE utiliza-se a decomposição das receitas e as elasticidades de cada uma delas. 
Chand (1993) busca abordar algumas métricas existentes na literatura apontando os pontos positivos que estas possuem e as críticas existentes. O autor conclui que, apesar das críticas existentes sobre estas métricas, as medidas de impulso fiscal são muito úteis para dar uma direção aproximada dos impactos da política fiscal.

Para o caso brasileiro existem diversos estudos que buscam analisar o impulso fiscal.

Bevilaqua e Werneck (1997) utilizam a metodologia de Blanchard (1990) para analisar o impulso fiscal no Brasil no período de hiperinflação. Nesta mesma linha, Pereira (1999), por meio da mesma metodologia, construiu uma série de gastos ciclicamente ajustado, mostrando que a parte endógena dos gastos tem forte relação negativa com a inflação, sendo esta uma clara evidência do efeito Bacha. É importante notar que a utilização da metodologia de Blanchard (1990) foi importante no Brasil para lidar com o período da hiperinflação, pois a estimação levava em consideração a inflação como uma das variáveis importantes para o ciclo. Entretanto, com o fim da hiperinflação, esta metodologia entrou em desuso para os dados do país.

Maciel (2006) estima o resultado orçamentário estrutural com base na metodologia proposta por $\mathrm{FMl}$, que faz a separação de componentes permanentes e cíclicos do balanço orçamentário. Pelos resultados observados, o ano que apresentou o maior fator cíclico foi 2003, enquanto aquele que apresentou o menor foi 2000.

Gobetti et al. (2010) estimam o resultado primário estrutural com base na metodologia de balanço neutro ao ciclo da OCDE e do FMI para o governo central e as administrações públicas. Como resultado, os autores encontram dois grandes ciclos de política fiscal: um primeiro de contração fiscal, que se iniciou em 1997 e foi até 2005, e outro expansão fiscal, de 2006 até 2010, último ano da análise.

Gobetti et al. (2011) analisam o resultado primário estrutural e o impulso fiscal das administrações públicas brasileiras de 1997 a 2010. Para isso, os autores criaram um primário recorrente e depois ajustaram as receitas para 0 efeito cíclico do produto e do preço do petróleo (neste caso, para ajustar receitas 
royalties e participação especial) por meio da metodologia de Escolano (2010). Ao final, os autores concluem sobre a relevância do resultado estrutural no contexto do debate sobre credibilidade e rigidez nas regras fiscais.

Daude et al. (2011) calcula as receitas ajustadas ao ciclo para o Brasil e outros países da América Latina utilizando a metodologia da OCDE, além de controlar para os preços de algumas commodities relevantes para os países em questão. Com base nestas estimativas, os autores calculam os estabilizadores automáticos e a ciclicalidade da política fiscal discricionária.

Banco Central do Brasil (2011) utiliza as metodologias do balanço ajustado neutro ao ciclo do FMI e OCDE e o método holandês, replicando um estudo realizado por Sidaoui (2003) para o caso mexicano, a fim de analisar o impulso fiscal no governo central. Como conclusão, observa-se que de 2001 a 2011 o governo central vem adotando ações discricionárias para adequar a postura fiscal aos ciclos econômicos.

Fernandes (2015) utiliza o modelo de componentes não observáveis que, por meio de um filtro de Kalman, requer que modelo seja representado na forma de estado de espaço, para com isso estimar o saldo fiscal estrutural com base na tendência obtida para a série do saldo primário.

IFI (2017) analisa o resultado primário estrutural do Brasil por meio da metodologia de balanço neutro ao ciclo utilizado pelo FMI. Primeiramente, foi calculado o superávit primário recorrente, depois foi utilizada a metodologia do FMI para obter o impulso fiscal. Como resultado, os autores obtêm que desde que haja um contingenciamento anunciado e executado em 2017, haverá um efeito importante da nova política fiscal sobre o primário do governo e, consequentemente, sobre o impulso fiscal.

Gobetti et al. (2017) estimam o primário estrutural para o Brasil com uma série de modificações em relação às metodologias usuais. Primeiro, se baseiam na metodologia de cálculo do PIB potencial proposta pela Comissão Europeia. Em seguida, realizam correções nas séries de receitas do governo, tornando possível diminuir o número de quebras estruturais derivadas de majoração de alíquotas ou desonerações fiscais, e estimam as elasticidades por meio do modelo de correção de erros. Por fim, os autores demonstram que a recessão 
deteriorou cerca de 4,8 pontos percentuais do PIB o resultado fiscal estrutural entre 2008 e 2016. 40\% desta deterioração é explicada pela expansão fiscal e $51 \%$ está relacionada à quebra estrutural na tendência do PIB.

SPE (2018) analisa o primário estrutural do Brasil com base em conceitos da atual metodologia idealizada por Fedelino et al. (2009) calculando a desagregação das receitas para encontrar a elasticidade de cada item para, posteriormente, realizar uma reagregação, encontrando a receita ajustada pelo ciclo, como a metodologia mais recente da OCDE faz uso.

Portanto, há uma série de métodos existentes na literatura que permitem obter o impulso fiscal, sem que haja uma metodologia que seja, efetivamente, superior à outra. É possível observar que para alguns órgãos governamentais brasileiros (IFI, SPE e IPEA) se faz uso de diferentes metodologias e técnicas que acabam apontando resultados diferentes. Com isso, buscaremos utilizar estas mais diferentes metodologias de forma a prover mais robustez e verificar se há diferenças significativas entre elas para o caso brasileiro, além de utilizarmos distintas métricas de produto potencial e verificar como influenciam o resultado final. Por fim, buscaremos mostrar como os resultados obtidos via nossos cálculos de impulso fiscal diferem daquele que seria obtido apenas com o resultado primário e se, nos últimos anos, houve alguma alteração nos resultados de impulso fiscal em comparação aos anos anteriores.

\subsection{Metodologia e Dados}

Nesta seção será apresentada a base de dados e as diferentes metodologias para o cálculo do impulso fiscal.

\subsubsection{Base de Dados}

Para criação do resultado primário, utilizamos dados mensais de receita líquida e despesa total do Tesouro Nacional, enquanto que para o Produto Interno Bruto utilizamos os resultados trimestrais divulgados pelo IBGE. Nossa amostra de dados compreende o período de 2000 a 2018. A opção por uma análise mais curta dos dados se deve ao fato de não querermos utilizar regimes distintos que poderiam apresentar quebras estruturais, como a passagem do 
câmbio fixo para o flutuante. Para o cálculo da elasticidade, iremos utilizar os dados trimestrais do PIB e da arrecadação deflacionados pelo deflator do PIB.

Optamos por calcular o impulso fiscal apenas para o Governo Central, ao contrário dos trabalhos de Gobetti et al. (2011 e 2017) e SPE (2018) que calculam o impulso para os Estados e municípios, além da União. Como apresentado nestes trabalhos, o impulso fiscal destes entes é pequeno em comparação ao Governo Central e, como precisamos retirar as operações oneoff e temporárias e há uma grande dificuldade em obter receitas e despesas extraordinárias para Estados e municípios, preferimos utilizar somente 0 resultado para o Governo Central.

Portanto, um primeiro ajuste necessário na base de dados é retirar as operações one-off e temporárias para, posteriormente, aplicarmos todas as metodologias. Para isso, identificamos e removemos as operações fiscais que possuem impacto em apenas um período, dado que estas operações grandes e não recorrentes podem distorcer a análise da situação fiscal e distorcer os ajustes realizados em cada metodologia. Para remover estas operações, atualizamos a base de dados presente em Chicoli (2015) que segue, em linhas gerais, o método de Joumard et al. (2008) utilizado para outros países levando em consideração: i. A recorrência da operação apresentada; ii. O tamanho do impacto (seguiremos a regra apresentada em Bornhorst et al. (2011) de um impacto no ano acima de $0,1 \%$ do PIB); iii. O efeito sobre o patrimônio líquido do governo geral.

\subsubsection{Metodologia para cálculo de impulso fiscal}

Após termos apresentado a base de dados do Governo Central e mostrarmos como procederemos para retirar as operações one-off e temporárias, vamos apresentar as metodologias que serão utilizadas, apresentando inicialmente as metodologias mais antigas e, posteriormente, as metodologias mais recentes. 


\subsubsection{Metodologia mais antigas para cálculo de impulso fiscal}

As metodologias mais antigas para cálculo do impulso fiscal realizam o ajuste da receita e da despesa ao ciclo econômico, chegando ao primário ciclicamente ajustado que é definido pelo Fundo Monetário Internacional no Fiscal Monitor (2017, p. 63) como o resultado fiscal que seria obtido sob as políticas correntes caso o produto fosse igual ao produto potencial. Abaixo, apresentamos como cada uma destas metodologias realiza este ajuste e obtêm, diretamente, o impulso fiscal.

Primeiramente, temos a metodologia do Fundo Monetário Internacional (FMI), desenvolvida por Dernburg (1975). Para fins de notação, definiremos esta métrica como FMI antigo:

$$
F M I=\left(\Delta G-\left(\frac{G_{o}}{Y_{o}^{P}}\right) * \Delta Y^{P}\right)-\left(\Delta T-\left(\frac{T_{0}}{Y_{0}}\right) * \Delta Y\right)
$$

Em que:

$\mathrm{G}=$ despesa do governo;

$T=$ receitas do governo;

$Y$ e $Y^{P}=$ PIB efetivo e PIB potencial, respectivamente;

$\Delta=$ Variação entre o ano atual e o ano anterior.

O subscrito 0 indica o período base, que seria um ano em que o produto efetivo se aproxima do produto potencial. Portanto, para este método, o impulso fiscal é obtido para o ajuste realizado nas receitas e despesas do governo em relação a este ano base.

Na equação (2), abaixo, apresentamos o método holandês, desenvolvido por Chand (1977):

$$
\text { Holandês }=\left(\Delta G-\left(\frac{G_{-1}}{Y_{-1}^{P}}\right) * \Delta Y^{P}\right)-\left(\Delta T-\left(\frac{T_{-1}}{Y_{-1}}\right) * \Delta Y\right)
$$

O subscrito -1 indica o período defasada em 12 meses. Portanto, sua única distinção em relação ao método do FMI antigo é que enquanto este realiza 
o ajuste no ano base, o método holandês utiliza o ano base sempre como o ano anterior para realizar o ajuste nas receitas e nas despesas.

$\mathrm{Na}$ equação (3), abaixo, apresentamos a metodologia da Organização para Cooperação e Desenvolvimento Econômico (OCDE) apresentada em OCDE (1983). Para fins de notação, definiremos esta metodologia como OCDE antigo:

$$
O C D E=\Delta\left(G-\rho_{G} *\left(\frac{G_{-1}}{Y_{-1}}\right) *\left(Y-Y^{P}\right)\right)-\Delta\left(T-\rho_{T}\left(\frac{T_{-1}}{Y_{-1}}\right) *\left(Y-Y^{P}\right)\right)
$$

Em que:

$\rho_{T}$ e $\rho_{G}=$ elasticidade da receita e da despesa do governo em relação ao PIB, respectivamente

Neste método, são calculadas elasticidades tanto das receitas quanto das despesas, diferindo, assim, dos métodos anteriores que assumem que as elasticidades das receitas e das despesas são iguais a um.

Desta forma, no método do FMI antigo e holandês, as receitas e despesas são consideradas ciclicamente neutras se variam na mesma proporção do produto nominal e potencial. Já no cálculo da OCDE antigo, as receitas e despesas são ciclicamente neutras se variam de acordo com as elasticidades estimadas.

Entretanto, surgiram diversas críticas a estes métodos, sendo uma delas que não fazia sentido ajustar toda a despesa do governo ao ciclo econômico, pois grande parte desta despesa não possui relação com o ciclo. Para o caso brasileiro, esta crítica é mais evidente ainda, pois a maior parte das despesas do governo federal são obrigatórias e determinadas independente da variação do PIB (Tesouro, 2018).

\subsubsection{Metodologia mais novas para cálculo de impulso fiscal}

Para lidar com os problemas das metodologias anteriores, surgiram as metodologias mais recentes que partem do primário estrutural. Para isso, seguiremos o passo a passo descrito por Bornhorst et al. (2011) que nos 
permitirão obter o resultado primário estrutural ${ }^{6}$ e, posteriormente, o resultado para o impulso fiscal:

1. Identificar e remover as operações fiscais que possuem impacto em apenas um período, dado que estas operações grandes e não recorrentes podem distorcer a análise da situação fiscal;

2. Retirar o impacto do ciclo econômico sobre as variáveis de arrecadação e despesa;

3. Retirar os efeitos de outros ciclos econômicos ou fatores, como aqueles relacionados a ativos e preços de commodities;

Portanto, em relação aos ajustes realizados nas metodologias anteriores, o primário estrutural é uma versão mais completa, pois realiza o passo 3 que retira o efeito de outros ciclos econômicos ou fatores. Sendo que o primeiro passo já foi realizado na base de dados e é aplicado em todas metodologias apresentadas, e o segundo passo é feito de forma distinta em cada metodologia.

Para estas novas metodologias, apresentamos, primeiramente, a metodologia do Fundo Monetário Internacional que utilizou como base o trabalho de Escolano (2010), que propõe um pequeno ajuste nas despesas e um ajuste nas receitas. Para fins de notação, definiremos este método como FMI novo.

Inicialmente, as despesas são ajustadas apenas para os gastos relacionados ao desemprego:

$$
G_{t}^{*}=G_{t}\left(\frac{\text { Desemprego }_{t}^{*}}{\text { Desemprego }_{t}}\right)^{\gamma}
$$

Em que:

$G_{t}^{*}$ é a despesa ajustada ao ciclo para o gasto com seguro desemprego em t

$G_{t}$ é a despesa com seguro desemprego

Desemprego $o_{t}^{*}$ é a taxa de desemprego pela NAIRU

Desemprego ${ }_{t}$ é a taxa de desemprego da economia em $\mathrm{t}$

\footnotetext{
${ }^{6}$ É importante notar que o cálculo do primário estrutural não é apenas utilizado como um passo intermediário para cálculo do impulso fiscal, mas também é a métrica utilizada como regra fiscal para verificação do resultado primário em países da União Europeia, Peru, Colômbia e Chile
} 
Para finalizar o ajuste pelo lado da despesa, após realizar esta alteração para o seguro desemprego, este é somado às outras despesas do governo do governo federal.

Pelo lado da receita, realiza-se o ajuste partindo-se de uma relação de proporcionalidade entre, de um lado, o quociente entre receitas observadas e ajustadas e, de outro, o produto efetivo e potencial.

$$
T_{t}^{*}=T_{t}\left(\frac{Y_{t}^{P}}{Y_{t}}\right)^{\rho_{G}}
$$

Em que:

$T_{t}^{*}$ é a receita ajustada em $\mathrm{t}$

Como é possível observar, parte importante do resultado obtido na metodologia apresentada acima dependerá do valor da elasticidade $\left(\rho_{G}\right)$. Para fins de notação, chamaremos esta métrica de FMI novo com quebras.

Entretanto, como a elasticidade pode apresentar algumas quebras estruturais, apresentamos abaixo uma nova métrica que nos permite realizar o ajuste pela receita levando em consideração possíveis quebras estruturais na elasticidade:

$$
T_{t}^{*}=\sum_{i=1}^{n} T_{t}\left(\frac{Y_{t}^{P}}{Y_{t}}\right)^{\rho_{G_{i}}}
$$

Em que $\mathrm{n}$ é o número de quebras estruturais apresentadas pela elasticidade da receita ao PIB

Portanto, nesta outra metodologia a elasticidade será alterada conforme forem encontradas quebras estruturais na série de dados. Para fins de notação, chamaremos esta métrica de FMI novo com quebras estruturais.

Por fim, seguiremos, em parte, o trabalho realizado por Fedelino et al. (2009) que é atualmente utilizado pela OCDE. Neste método, calcula-se a despesa tal qual a metodologia de FMI novo. Entretanto, para a receita calcularemos tal qual (5), mas para cada grupo de imposto individualmente. Posteriormente, somaremos os resultados obtidos para cada imposto chegando ao resultado ajustado para a receita. Para fins de notação, definiremos este método como OCDE novo. 
Abaixo, apresentamos as categorias de receita criadas inspiradas na agregação realizada por SPE (2017):

- Tributos sobre renda do trabalho (TRT): Imposto de Renda de Pessoa Física e Imposto de Renda Retido na Fonte - Rendimentos do Trabalho;

- Tributos sobre a folha de pagamento (TFP): Receita do Regime Geral de Previdência Social e Salário Educação;

- Tributos sobre a renda corporativa (TRC): Imposto de Renda Pessoa Jurídica e Contribuição Social sobre Lucro Líquido;

- Tributos indiretos (TI): Impostos sobre Produtos Industrializados, exceto importação, PIS/PASEP e Cofins;

- Tributos sobre importação (TM): Imposto de Importação e Imposto sobre Produtos Industrializados - importação;

- $\quad$ Tributos sobre ganhos de capital (TGC): Imposto de Renda Retido na Fonte - Rendimentos do Capital

Como apresentado em Bornhorst et al. (2011), os métodos novos do FMI e da OCDE, são classificados como agregado e desagregado, respectivamente, e possuem algumas diferenças que fazem sentido utilizar um método ou outro, como:

- O método desagregado, geralmente, oferece mais vantagens em relação ao agregado em termos de estabilidade e uma melhor relação do efeito do ciclo econômico sobre os mais variados tipos de impostos

- Já o método agregado é superior ao desagregado quando há poucas aberturas de impostos nos dados e sua desvantagem em relação ao método desagregado diminui nos casos em que a composição das receitas e gastos e a elasticidade estes itens se mantêm, em grande parte do tempo, constantes.

Portanto, tendo realizado os três passos descritos em Bornhorst et al. (2011), obtemos o primário estrutural. Para chegarmos ao impulso fiscal, devemos fazer a diferença do resultado entre os anos, como apresentado abaixo: 


$$
I F=\Delta G^{*}-\Delta T^{*}
$$

Por fim, como há uma série de passos intermediários para obter o impulso fiscal, apresentamos, nas próximas subseções, as metodologias que nos permitem realizar o cálculo do produto potencial, das elasticidades, e como retirar o efeito de outros fatores e ciclos.

\subsubsection{Metodologia para cálculo do produto potencial}

Como apresentado nas metodologias anteriores, há um processo de ajuste nas receitas e despesas que busca retirar a influência dos ciclos econômicos. Para realizar este ajuste, é necessário determinar uma metodologia que possibilite realizar o cálculo do produto potencial.

Uma das metodologias mais clássicas para o cálculo do produto potencial é por meio do filtro HP, que se tornou muito popular devido a facilidade do seu cálculo em comparação às outras metodologias existentes.

Entretanto, como apontado por Gobetti et al. (2017), há uma série de problemas relacionados ao uso do filtro HP como mecanismo para obtenção do PIB potencial. Dentre estas críticas estão as revisões retroativas significativas com a adição de novos dados, a falta de estrutura teórica e o viés de final da amostra. Na tentativa de minimizarmos a última crítica, utilizaremos dados projetados até 2022 obtidos do Sistema Focus, como divulgado pelo BCB.

Na tentativa de contornar estes problemas apresentados para o cálculo do filtro HP, utilizaremos, também, outra metodologia de cálculo do produto potencial por meio da função de produção, seguindo, para o caso brasileiro, a metodologia adotada por Souza-Junior e Caetano (2013) e as adaptações feitas por Souza-Junior (2015) que buscam minimizar o viés de fim de amostra do filtro HP para a obtenção da tendência das variáveis intermediárias da função de produção. 
Portanto, utilizaremos duas metodologias distintas para o cálculo do produto potencial com o objetivo de verificarmos se a alteração deste método leva a grandes alterações no resultado final da nossa métrica de impulso fiscal ${ }^{7}$.

\subsubsection{Cálculo da Elasticidade}

Como apresentado anteriormente, para a obtenção do impulso fiscal, para algumas metodologias, é necessário o cálculo da elasticidade da receita e dos impostos do governo.

Para o cálculo da elasticidade, após já termos excluído as operações temporárias na série de receita, ainda precisamos utilizar o método de tax correction adotada por Gobetti et al. (2017) que busca realizar uma harmonização das séries da receita supondo que não houve alterações significativas na legislação tributária que tendem a causar quebras estruturais nas séries de alguns impostos e, em alguns casos, na receita como um todo.

Seguiremos a estratégia parcimoniosa dos autores que utilizamos como referência, pois não é simples captar todas as alterações tributárias do país. Com isso, faremos dois ajustes principais: corrigiremos as onerações que serão acrescidas ou subtraídas nas séries passadas e as desonerações que serão acrescidas no período posterior a sua adoção.

Quanto às onerações, serão consideradas as cinco medidas abaixo:

1. Aumento da alíquota da Cofins de $2 \%$ para $3 \%$ e início do pagamento para entidades financeiras em março de 1999;

2. Alteração no regime de PIS/Cofins do regime cumulativo para o regime não-cumulativo em dezembro de 2002

3. Aumento da alíquota da Cofins das instituições financeiras de $3 \%$ para $4 \%$ em outubro de 2003;

4. Instituição da cobrança de PIS/Cofins sobre produtos importados a partir de maio de 2004;

\footnotetext{
${ }^{7} \mathrm{O}$ impulso calculado pelo método do FMI antigo tem como referência um ano base onde 0 produto efetivo se aproxima do produto potencial. Para o caso do filtro HP, a base é o ano de 2011, enquanto para a função produção, o ano base é de 2002.
} 
5. Majoração das alíquotas de CSLL nas instituições financeiras de $9 \%$ para $15 \%$ em junho de 2008 e de $15 \%$ para $20 \%$ em outubro de 2015 ;

6. Extinção da CPMF em janeiro de 2008.

Para as desonerações, há uma série de medidas adotadas ao longo do tempo ${ }^{8}$. Focaremos naquelas que tem maior representatividade na receita e que possuem seus valores calculados pela Secretaria da Receita Federal em seus relatórios mensais. Estes dados começarão na nossa série a partir de janeiro de 2012, período em que a Receita Federal disponibiliza em seu site os valores e as respectivas desonerações.

Portanto, tendo apresentado o ajuste quanto as onerações $e$ desonerações, temos que todos os dados de arrecadação terão ajuste sazonal pelo método ARIMA X-12, enquanto para o PIB utilizaremos o dado já dessazonalizado e divulgado pelo IBGE.

A metodologia de estimação da elasticidade seguirá Ribeiro (2016) que analisa a elasticidade da arrecadação ao PIB por meio de metodologia de Dynamic Ordinary Least Square (DOLS) utilizando diversos parâmetros para medir o crescimento econômico e a arrecadação.

Inicialmente, são realizados diversos testes de raiz unitária para verificar se as séries são estacionárias. Para estimação da elasticidade, como há uma relação de longo prazo entre as variáveis, o ideal seria utilizarmos o modelo de Vetor de Correção de Erros (VEC). Entretanto, como apontado por Banerjee et al (1993), quando a amostra é pequena, que é o nosso caso, essa metodologia não é muito adequada. Portanto, deve-se procurar outra metodologia que se adeque à amostra pequena que possuímos.

Dentre as diversas metodologias possíveis de serem utilizadas, optamos pela estimação por meio do Dynamic Ordinary Least Squares (DOLS) desenvolvida por Stock e Watson (1993), que foi a mesma utilizada por Ribeiro (2016). Esse método, além de ser superconsistente, ainda resolve os problemas

\footnotetext{
${ }^{8}$ Gobetti et al. (2017) calcularam mais de 380 medidas entre 2007 e 2016.
} 
de autocorrelação dos resíduos, endogeneidade e simultaneidade presentes na estimação por OLS.

Com isso, a equação a ser estimada é dada por:

$$
\log \left(T_{t}\right)=\beta_{0}+\beta_{1} \log \left(Y_{t}\right)+\alpha \Delta \log \left(Y_{t}\right)+\sum_{j=1} \gamma_{j} \Delta \log \left(\mathrm{Y}_{-\mathrm{j}}\right)+\sum_{j=1} \psi_{j} \Delta \log \left(Y_{j}\right)+u_{t}
$$

Em que: $T_{t}$ é a variável de receita no período t e $Y_{t}$ é o PIB no período e os somatórios são os lags e leads que serão definidos de acordo com o critério de informação de Akaike.

Para verificar a existência de possíveis quebras estruturais nos dados, utilizaremos a metodologia de Bai e Perron (1998) que analisa quebras estruturais endógenas no modelo.

Com isso, temos a metodologia que será utilizada para obter as elasticidades cobertas neste trabalho.

\subsubsection{Cálculo para retirada dos efeitos de outros ciclos e fatores}

Por fim, tendo apresentado as metodologias que retiram a influência do ciclo, suas principais diferenças e características e os passos intermediários que levam ao seu cálculo, falta a última parte que nos levará ao resultado estrutural que é retirar outros fatores que influenciam o resultado, mas não estão relacionados ao ciclo econômico. Para o caso brasileiro, o único fator que possui influência sobre as finanças públicas dentre aqueles apresentados em Bornhorst et al. (2011) é o efeito do preço do petróleo, que se reflete na arrecadação dos royalties e participação especial.

Para calcularmos as receitas do petróleo, iremos utilizar o resultado líquido das transferências para os entes subnacionais. Como parte relevante ${ }^{9}$ destas receitas é repassada aos Estados e municípios, a variação do preço do

\footnotetext{
${ }^{9}$ Segundo a lei oㅜ 12.734 , para os contratos em vigor até 2013 a União teria direito a $30 \%$ do total arrecadado com royalties e $50 \%$ da receita com participação especial, o restante é divido entre estados e municípios. Para os contratos após 2013, a União tem direito a $20 \%$ do total arrecadado com royalties e $43 \%$ da receita com participação especial, o restante é divido entre estados e municípios. Dado o efeito desta divisão e o total arrecadado, acaba não sendo muito significativo, em termos totais, o efeito da variação do petróleo nas receitas da União.
} 
petróleo terá pouco efeito sobre os nossos resultados. Para seu cálculo, utilizaremos a metodologia tradicional de acumularmos em 12 meses a receita líquida do petróleo e utilizaremos o filtro HP que nos dará qual seria a tendência. Logo, a diferença entre o valor observado e a tendência seria a receita extraordinária oriunda dos movimentos no preço do petróleo.

Com isso, tendo apresentado todas as metodologias necessárias para obtenção do impulso fiscal, na próxima seção serão apresentados os resultados destas metodologias e do ajuste na base de dados.

\subsection{Resultados}

Nesta seção, serão apresentados os resultados do resultado primário estrutural e, posteriormente, do impulso fiscal. Primeiramente, será apresentado o resultado primário após a retirada das operações one-off e temporárias na receita e despesa. Depois, serão apresentados os resultados do produto potencial para as metodologias do filtro HP e da função de produção. Posteriormente, apresentamos o resultado obtido para o cálculo das elasticidades. Por fim, utilizaremos as diversas metodologias para o cálculo do impulso fiscal e aplicaremos as diferentes métricas de produto potencial, apresentando os resultados para o filtro HP e para o produto potencial.

\subsubsection{Retirada das operações one-off e temporárias}

Como apresentado na parte de base de dados, o primeiro passo para a obtenção dos impulsos fiscais é a retirada das operações que possuem impacto temporário e que podem acabar distorcendo a análise da situação fiscal e o cálculo das elasticidades.

Para isso, seguindo a metodologia de Joumard et al. (2008) como utilizada para o caso brasileiro por Chicoli (2015), retiramos as receitas advindas da contabilidade criativa, receitas e despesas extraordinárias, tais como: receitas com outorgas por assinatura de contratos de concessão, descontar receitas de dividendos que diferem da relação dividendo/lucro no período pré e pós crise e 
pagamentos à vista no Refis ${ }^{10}$. Além destes ajustes, iremos redistribuir as despesas do governo central devido aos atrasos ocorridos pelas pedaladas fiscais e ajustadas por Banco Central (2016), a realocação de parte do pagamento de restos a pagar no fim de dezembro de 2016 para o início de janeiro de 2017, a repatriação de recursos, as despesas com as eleições de 2018 e o subsídio ao diesel após a greve dos caminhoneiros de 2018.

Abaixo, apresentamos o gráfico com o resultado primário oficial divulgado pelo Tesouro Nacional e o resultado primário após a retirada destas operações one-off e temporárias.

Figura 4: Resultado primário oficial e primário excluindo as operações one-off e temporárias (em \% do PIB)

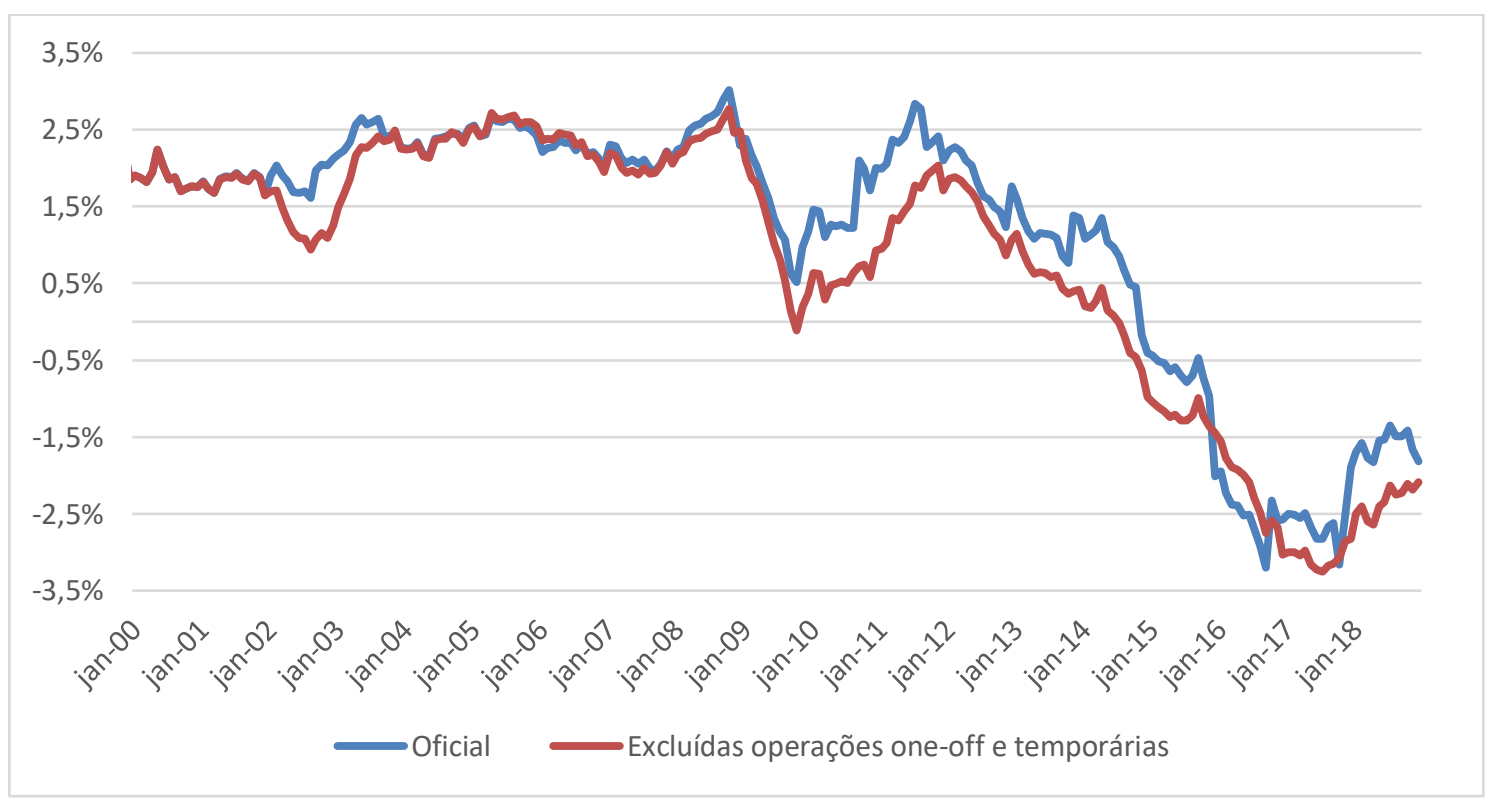

Fonte: IBGE e Tesouro Nacional

Como pode ser observado acima, a partir do final de 2008 houve um descolamento significante entre o resultado oficial e o resultado que exclui as operações one-off e temporárias que se manteve por todo período subsequente. É interessante notar que o resultado que exclui as operações one-off e temporárias se manteve inferior ao oficial por quase todo período posterior a 2008, com exceção do período entre 2015 e 2016, quando o resultado das pedaladas fiscais entraram de uma vez só no resultado oficial, enquanto no resultado que exclui as operações one-off e temporárias, elas foram ajustadas

${ }^{10}$ Para maiores informações sobre estas operações, ver Chicoli (2015). 
de acordo com o período que deveriam ter sido pagas. Por fim, é interessante notar a trajetória do resultado primário para o período do final de 2016 até o final de 2018. Enquanto o primário oficial teve uma considerável melhora em 2017 devido aos recursos da repatriação e depois voltou a cair no final de 2018, o resultado que exclui as operações one-off e temporárias vem em contínua melhora, mas em patamares inferiores ao oficial, apesar de ambos ainda estarem distantes de um superávit primário.

\subsubsection{Cálculo do produto potencial}

Como apresentado na seção de metodologia, optamos por utilizar duas diferentes métricas para o cálculo do produto potencial. Abaixo, apresentamos o resultado para o hiato do produto, que é uma forma melhor de apresentar a distância entre o produto efetivo e o produto potencial, para o filtro HP e a função de produção.

\section{Figura 5: Hiato do Produto pelo filtro HP e pela função de produção}

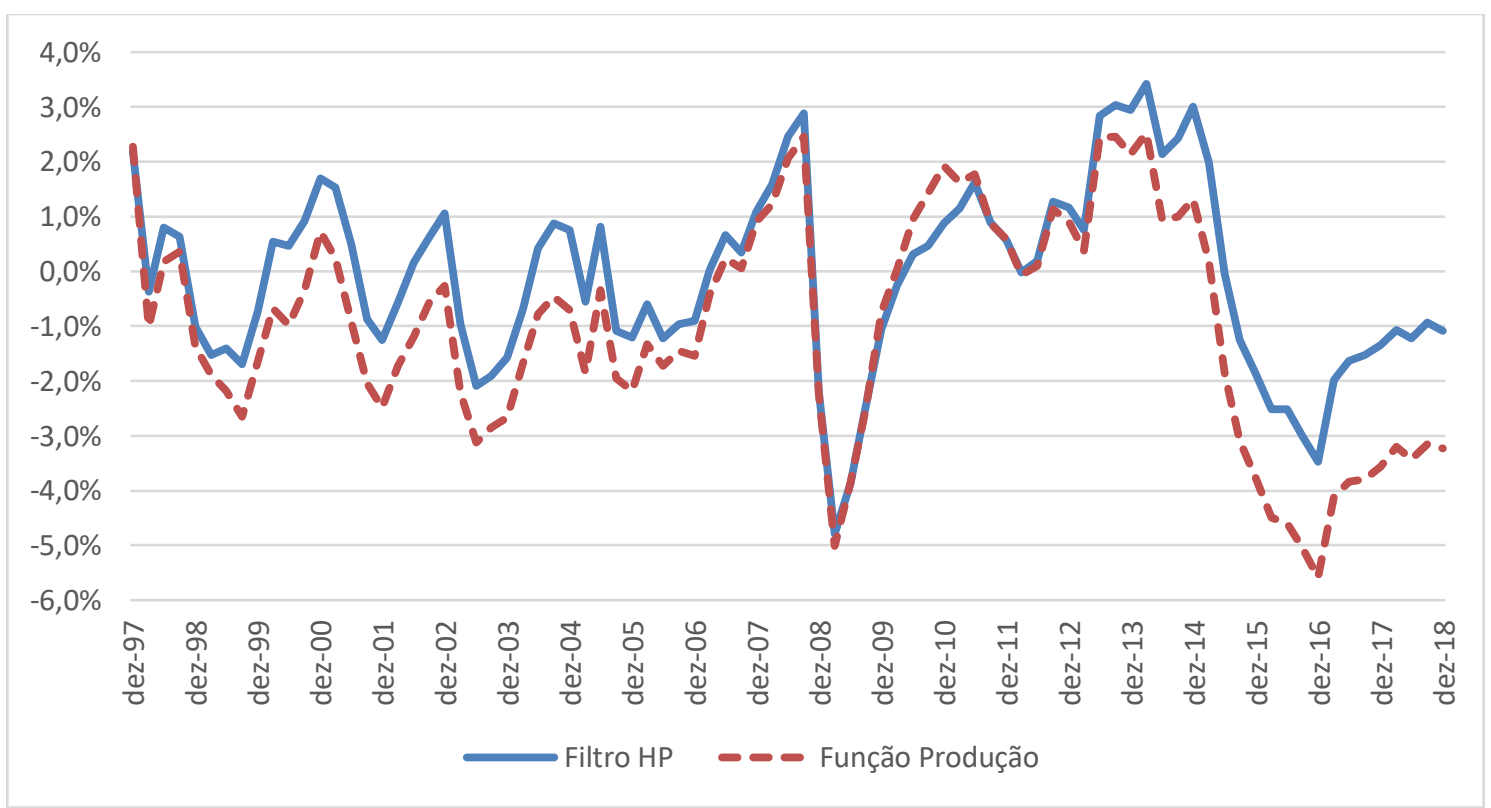

Fonte: IBGE e Banco Central do Brasil

O gráfico acima mostra que o hiato do produto pela função de produção ficou por quase todo período abaixo do Filtro HP, com destaque para o período recente em que o hiato se mostra significativamente negativo, pouco abaixo de $-3 \%$, enquanto para o Filtro HP o hiato está próximo de $-1 \%$ para a última observação de dezembro de 2018. 
Essa diferença indica que, no processo de ajuste ao ciclo, poderemos observar significativas diferenças entre os impulsos fiscais para cada métrica utilizada.

\subsubsection{Resultados da Elasticidade}

Com as metodologias que serão utilizadas neste trabalho tendo sido apresentadas anteriormente, primeiramente verificaremos se a medida de receita em questão possui raiz unitária e, posteriormente, faremos o cálculo da elasticidade.

Para a raiz unitária, realizamos o teste de Dickey e Pantula (1987) para mais de uma raiz unitária ${ }^{11}$. Rejeitamos a hipótese de duas raízes unitárias, porém não rejeitamos a hipótese uma raiz unitária para as variáveis em questão.

Após rejeitarmos a hipótese de duas ou mais raízes unitárias, realizamos os principais testes para verificar se rejeitamos ou não a hipótese de uma raiz unitária. Nestes testes cobrimos as possibilidades: do erro ser um resíduo branco (ADF); maior poder de teste caso as variáveis possuam constante e tendência (DF-GLS); eficiente para o erro heterocedástico (NG-Perron); e inversão da hipótese nula (KPSS). Em todos os testes não rejeitamos a hipótese de uma raiz unitária, portanto ambas as variáveis são integradas de ordem um.

Como todas as variáveis possuem raiz unitária, podemos fazer a estimação por meio da metodologia DOLS. Abaixo, apresentamos uma tabela com os resultados obtidos para a elasticidade da arrecadação em relação ao Produto Interno Bruto da economia:

\footnotetext{
${ }^{11}$ Testaremos para duas raízes unitárias, pois séries econômicas não apresentam um número de raízes unitárias superiores a essa.
} 
Tabela 1: Elasticidade da Arrecadação em relação ao PIB

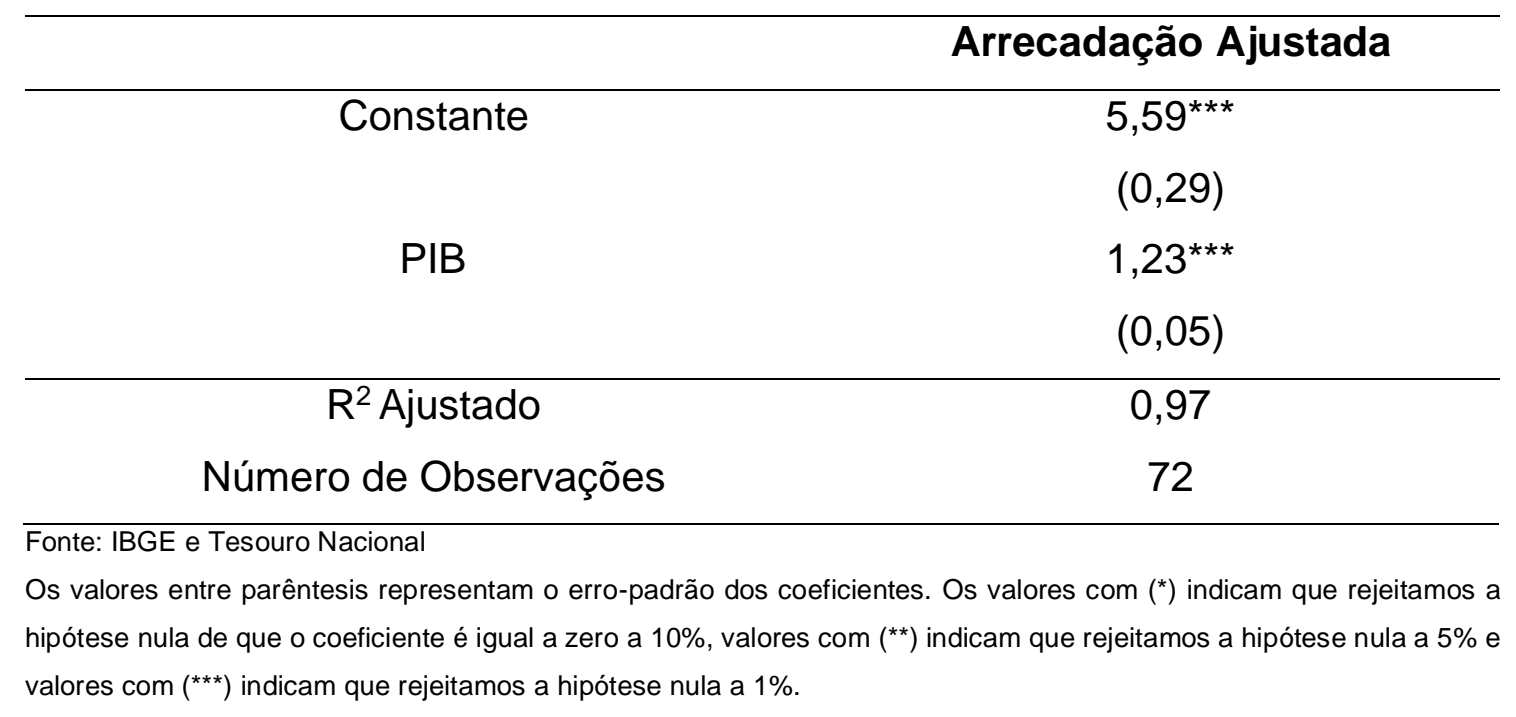

Como é possível observar acima, a elasticidade é superior a 1 para nossa amostra completa que compreende o período de 1999 a 2017. O resultado é semelhante ao obtido por Gobetti et al (2017), ainda que no trabalho não houvesse uma janela temporal semelhante. Portanto, nosso resultado difere da maioria dos trabalhos realizados para elasticidade da arrecadação no Brasil, como Schettini et al. (2011) e Oreng (2011) que encontraram elasticidade bem superior a unidade.

Desta forma, obtivemos o valor da elasticidade que nos possibilita calcular o impulso fiscal para a metodologia nova do FMI. Agora, por meio do teste de quebra estrutural de Bai e Perron (1998), verificaremos a quantidade de quebras estruturais na elasticidade e calcularemos a elasticidade para cada quebra em particular para, posteriormente, calcularmos o impulso fiscal.

Tabela 2: Quebra Estrutural

\begin{tabular}{cccc}
\hline Variável & $\begin{array}{c}\text { Número de } \\
\text { Quebras }\end{array}$ & $\begin{array}{c}\text { Período da } \\
\text { Quebra }\end{array}$ & Estatística F \\
\hline Arrecadação Ajustada & 1 & $2013 \mathrm{Q} 4$ & 11,47 \\
\hline
\end{tabular}

Fonte: IBGE e Tesouro Nacional

O resultado apresentado acima demonstra que há uma quebra estrutural na arrecadação do governo federal e essa se situa no período que divide o início 
da maior recessão já datada do país segundo o Comitê de Datação do Ciclo Econômico (Codace) da Fundação Getúlio Vargas. Com isso, faremos duas regressões para estes períodos distintos para verificar qual a elasticidade da arrecadação nos períodos pré e pós a grande recessão brasileira.

A tabela abaixo mostra os resultados das regressões:

Tabela 3: Resultado da elasticidade entre quebras estruturais

\begin{tabular}{cccc}
\hline Variável & $\begin{array}{c}\text { Período da } \\
\text { Quebra }\end{array}$ & $\begin{array}{c}\text { Coeficiente de } \\
\text { Elasticidade }\end{array}$ & $\begin{array}{c}\text { № de } \\
\text { Observações }\end{array}$ \\
\hline & $2000 \mathrm{Q} 1-$ & $1,36^{\star \star *}$ & 55 \\
Arrecadação Ajustada & $2013 \mathrm{Q} 4$ & $(0,15)$ & \\
& $2014 \mathrm{Q} 1-$ & $1,06^{\star \star \star}$ & 19 \\
& $2018 \mathrm{Q} 4$ & $(0,11)$ & \\
\hline
\end{tabular}

Fonte: IBGE e Tesouro Nacional

Os valores entre parêntesis representam o erro-padrão dos coeficientes. Os valores com $\left({ }^{*}\right)$ indicam que rejeitamos a hipótese nula de que o coeficiente é igual a zero a $10 \%$, valores com $\left(^{* *}\right)$ indicam que rejeitamos a hipótese nula a $5 \%$ e valores com $\left(^{* * *}\right)$ indicam que rejeitamos a hipótese nula a $1 \%$.

O resultado acima mostra que, no período anterior à recessão, a elasticidade era mais elevada e significativamente acima da unidade. Já para o período posterior à recessão, a elasticidade se aproximou da unidade.

Tendo estes valores de elasticidade para a quebra estrutural no nosso modelo, podemos calcular o impulso fiscal pela metodologia nova do FMI com quebras estruturais utilizando estes distintos valores de elasticidade.

Após termos calculado a elasticidade da arrecadação total que nos possibilita obter o impulso fiscal para o método do FMI novo, iremos obter a elasticidade para cada componente da receita e, com isso, calcularmos o impulso fiscal para a metodologia da OCDE novo. Antes de realizar a estimação, realizamos, também, os testes de raiz unitária para cada componente da receita em que, novamente, não rejeitamos a hipótese de uma raiz unitária, portanto todas as variáveis são integradas de ordem 1.

Com isso, podemos prosseguir para a estimação das variáveis por DOLS e verificarmos qual a elasticidade de cada grupo de imposto em relação ao Produto Interno Bruto. 
Tabela 4: Elasticidade do Grupo de Impostos e Contribuições em relação ao PIB

\begin{tabular}{|c|c|c|c|c|c|c|}
\hline & TRT & TFP & TRC & TI & TM & TGC \\
\hline \multirow[t]{2}{*}{ Constante } & $1,86^{\star \star \star}$ & $3,26^{\star \star \star}$ & $3,53^{\star \star \star}$ & $7,89^{\star \star \star}$ & $2,33^{\star \star \star}$ & $6,81^{\star \star \star}$ \\
\hline & $(0,37)$ & $(0,19)$ & $(0,92)$ & $(0,23)$ & $(0,65)$ & $(0,47)$ \\
\hline \multirow[t]{2}{*}{ PIB } & $1,64^{\star \star *}$ & $1,61^{\star \star *}$ & $1,43^{\star \star \star}$ & $0,68^{\star * *}$ & $1,41^{\star \star *}$ & $0,52^{\star \star \star}$ \\
\hline & $(0,07)$ & $(0,04)$ & $(0,19)$ & $(0,05)$ & $(0,13)$ & $(0,10)$ \\
\hline $\mathrm{R}^{2}$ Ajustado & 0,96 & 0,99 & 0,80 & 0,88 & 0,88 & 0,69 \\
\hline Número de & 62 & 70 & 59 & 69 & 71 & 68 \\
\hline Observações & & & & & & \\
\hline
\end{tabular}

Fonte: IBGE e Tesouro Nacional

Os valores entre parêntesis representam o erro-padrão dos coeficientes. Os valores com $\left({ }^{*}\right)$ indicam que rejeitamos a hipótese nula de que o coeficiente é igual a zero a $10 \%$, valores com $\left.{ }^{* *}\right)$ indicam que rejeitamos a hipótese nula a $5 \%$ e valores com $\left(^{* \star *}\right)$ indicam que rejeitamos a hipótese nula a $1 \%$.

Como é possível observar, quatro dos seis grupos de impostos e/ou contribuições arrecadadas pelo governo federal apresentam elasticidade superior à unidade ${ }^{12}$, estando de acordo com o resultado observado para a arrecadação total.

Portanto, temos os resultados da elasticidade da arrecadação como um todo, para cada quebra estrutural e para cada grupo de imposto individualmente. Com isso, é possível calcularmos o impulso fiscal para as metodologias apresentadas anteriormente.

\subsubsection{Resultado Primário Estrutural}

Tendo realizado a retirada das operações one-off e temporárias, calculado os resultados para o produto potencial e as elasticidades, utilizado as diferentes metodologias para retirar o efeito do ciclo econômico e excluído outros ciclos e fatores, no caso brasileiro, as receitas com o petróleo, conseguimos obter o resultado primário estrutural para as metodologias do FMI novo, FMI novo com quebras estruturais e OCDE novo.

\footnotetext{
${ }^{12} \mathrm{O}$ teste de Wald mostra que o valor do coeficiente é diferente de 1.
} 
Abaixo, apresentamos o primário estrutural como uma média de cada uma das metodologias acima para cada um dos métodos de produto potencial, o resultado primário oficial e o resultado primário que exclui as operações one-off e temporárias.

Figura 6: Resultados primários por diferentes métricas (em \% do PIB)

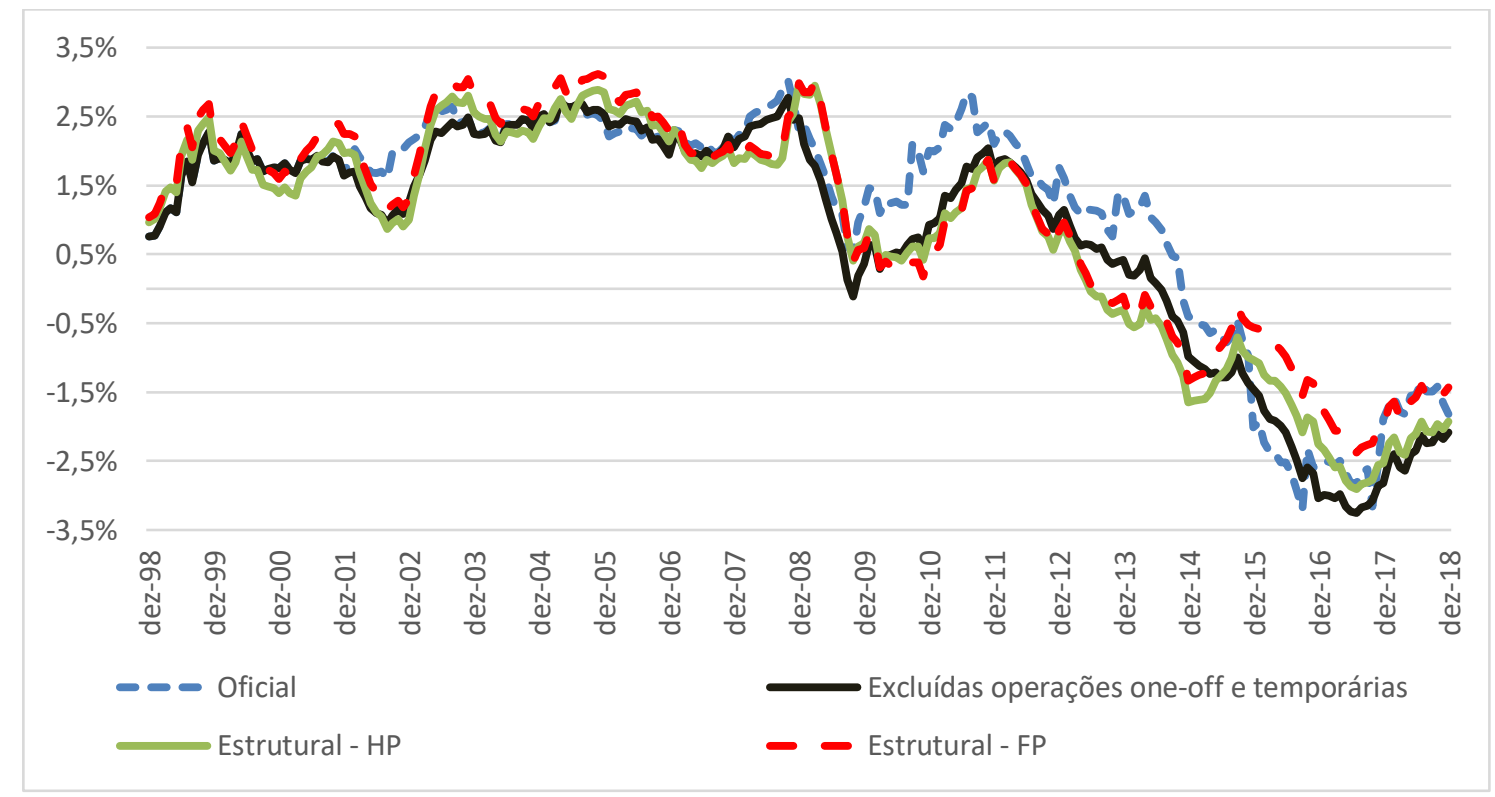

Fonte: IBGE e Tesouro Nacional

Pelo gráfico acima, é possível perceber que a exclusão das operações one-off e temporárias possui grande importância para o cálculo do resultado estrutural, pois apesar da diferença de magnitude para estas métricas, a tendência é determinada por aquela métrica, mostrando quão significante são estas operações no resultado primário oficial. Outro ponto interessante, principalmente para o período recente, é a diferença de magnitude para os resultados estruturais pelo filtro HP e para a função de produção, que reflete a diferença observada no tamanho dos hiatos para cada métrica. Por fim, é importante notar que, independente da métrica, ainda há um ajuste fiscal significativo para o país voltar a ter um resultado primário superavitário.

\subsubsection{Resultados do Impulso Fiscal}

Tendo apresentado os resultados da elasticidade necessários para 0 cálculo do resultado primário estrutural, mostramos abaixo uma tabela que resume o resultado de impulso fiscal obtido para o Governo Central para todas 
as metodologias utilizando como cálculo do produto potencial o filtro HP, além da variação do resultado primário do resultado primário oficial.

Tabela 5: Resultado de Impulso Fiscal para filtro HP (em \% do PIB)

\begin{tabular}{|c|c|c|c|c|c|c|c|c|}
\hline \multicolumn{9}{|c|}{ Metodologia HP } \\
\hline Período & $\begin{array}{c}\text { FMI } \\
\text { Antigo }\end{array}$ & Holandês & $\begin{array}{c}\text { OCDE } \\
\text { Antigo }\end{array}$ & $\begin{array}{l}\text { FMI } \\
\text { Novo }\end{array}$ & $\begin{array}{c}\text { FMI } \\
\text { Novo - } \\
\text { Com } \\
\text { Quebras }\end{array}$ & $\begin{array}{l}\text { OCDE - } \\
\text { Novo }\end{array}$ & Média & $\begin{array}{c}\text { Primário } \\
\text { Oficial }\end{array}$ \\
\hline 2002 & $0.8 \%$ & $0.8 \%$ & $0.3 \%$ & $0.8 \%$ & $0.8 \%$ & $0.7 \%$ & $0.7 \%$ & $-0.7 \%$ \\
\hline 2003 & $-1.3 \%$ & $-1.3 \%$ & $-1.2 \%$ & $-1.7 \%$ & $-1.7 \%$ & $-1.6 \%$ & $-1.5 \%$ & $-0.4 \%$ \\
\hline 2004 & $0.0 \%$ & $0.1 \%$ & $-0.6 \%$ & $-0.1 \%$ & $-0.1 \%$ & $-0.2 \%$ & $-0.1 \%$ & $-0.5 \%$ \\
\hline 2005 & $-0.4 \%$ & $-0.3 \%$ & $-0.3 \%$ & $-0.8 \%$ & $-0.8 \%$ & $-0.3 \%$ & $-0.5 \%$ & $-0.2 \%$ \\
\hline 2006 & $0.6 \%$ & $0.7 \%$ & $0.4 \%$ & $0.4 \%$ & $0.4 \%$ & $0.4 \%$ & $0.5 \%$ & $0.2 \%$ \\
\hline 2007 & $0.1 \%$ & $0.2 \%$ & $-0.4 \%$ & $0.1 \%$ & $0.1 \%$ & $0.0 \%$ & $0.0 \%$ & $-0.3 \%$ \\
\hline 2008 & $-0.3 \%$ & $-0.3 \%$ & $0.0 \%$ & $-0.8 \%$ & $-0.8 \%$ & $-0.7 \%$ & $-0.5 \%$ & $-0.9 \%$ \\
\hline 2009 & $2.1 \%$ & $2.1 \%$ & $1.8 \%$ & $2.1 \%$ & $2.1 \%$ & $2.1 \%$ & $2.1 \%$ & $1.4 \%$ \\
\hline 2010 & $-0.1 \%$ & $-0.2 \%$ & $-0.3 \%$ & $-0.1 \%$ & $-0.2 \%$ & $-0.2 \%$ & $-0.2 \%$ & $-1.0 \%$ \\
\hline 2011 & $-0.7 \%$ & $-0.8 \%$ & $-0.9 \%$ & $-0.9 \%$ & $-0.9 \%$ & $-0.9 \%$ & $-0.9 \%$ & $-0.3 \%$ \\
\hline 2012 & $0.7 \%$ & $0.7 \%$ & $0.5 \%$ & $0.6 \%$ & $0.6 \%$ & $0.6 \%$ & $0.6 \%$ & $0.4 \%$ \\
\hline 2013 & $1.0 \%$ & $1.0 \%$ & $0.6 \%$ & $1.0 \%$ & $1.0 \%$ & $1.0 \%$ & $0.9 \%$ & $0.0 \%$ \\
\hline 2014 & $1.6 \%$ & $1.4 \%$ & $1.3 \%$ & $1.4 \%$ & $1.4 \%$ & $1.4 \%$ & $1.4 \%$ & $1.7 \%$ \\
\hline 2015 & $-0.7 \%$ & $-0.9 \%$ & $0.0 \%$ & $-1.1 \%$ & $-0.8 \%$ & $-1.0 \%$ & $-0.8 \%$ & $1.6 \%$ \\
\hline 2016 & $1.4 \%$ & $1.2 \%$ & $1.8 \%$ & $1.2 \%$ & $1.4 \%$ & $1.2 \%$ & $1.4 \%$ & $0.6 \%$ \\
\hline 2017 & $-0.1 \%$ & $-0.1 \%$ & $-0.2 \%$ & $-0.1 \%$ & $-0.2 \%$ & $0.0 \%$ & $-0.1 \%$ & $-0.6 \%$ \\
\hline 2018 & $-0.4 \%$ & $-0.6 \%$ & $-0.7 \%$ & $-0.5 \%$ & $-0.6 \%$ & $-0.5 \%$ & $-0.5 \%$ & $0.0 \%$ \\
\hline
\end{tabular}

Fonte: Tesouro Nacional, Banco Central do Brasil.

Primeiro, é importante definir que resultados no impulso fiscal positivos significam que a política foi expansionista, enquanto para os casos em que o resultado do impulso fiscal é negativo, implica que a política fiscal foi contracionista.

É interessante notar, primeiramente, que apesar das metodologias apresentarem resultados levemente distintos para o tamanho do impulso fiscal, o sinal obtido é igual para quase todos os anos, com exceção de pequenas diferenças para anos que estão próximos da estabilidade. Somente a metodologia antiga da OCDE que tende a diferir mais da média que as outras. Essa homogeneidade nos resultados é uma característica importante, pois demonstra que, independente da metodologia utilizada, os resultados são muito semelhantes e a média é uma métrica robusta para o cálculo. Portanto, apesar 
das métricas mais recentes parecerem mais adequadas para o caso brasileiro, as métricas mais antigas não apresentam muita diferença em relação àquelas para o cálculo do impulso fiscal.

Outro ponto interessante, é que a utilização das diversas metodologias para o impulso fiscal é muito mais adequada do que simplesmente observar a variação do resultado primário oficial. Como fica bem claro no exemplo acima, para muitos anos, observar a variação do resultado primário levaria a conclusões errôneas sobre a direção da política fiscal e, principalmente, sobre sua magnitude.

Os resultados da tabela acima indicam alguns pontos interessantes da política fiscal da economia brasileira. Primeiro, é interessante notar que a piora nas contas públicas que se iniciou após a crise mundial com a mudança na política fiscal e se tornou mais evidente após 2011 é corroborada pelo resultado do impulso fiscal. De 2012 a 2016, com exceção de 2015, o impulso fiscal foi positivo em todas as metodologias, indicando que houve uma piora contínua nas contas públicas nestes anos mesmo quando controlamos para a recessão e o fraco crescimento observado neste período. Outro ponto relevante, é que nos anos de 2017 e 2018, após a adoção da emenda do teto de gastos, o impulso fiscal foi negativo, portanto, sua adoção pode ter auxiliado neste resultado.

Abaixo, apresentamos os resultados utilizando a metodologia da Função de Produção para obtenção dos impulsos fiscais. 
Tabela 6: Resultado de Impulso Fiscal para Função de Produção (em \% do PIB)

\begin{tabular}{|c|c|c|c|c|c|c|c|c|}
\hline \multicolumn{9}{|c|}{ Metodologia FP } \\
\hline Período & $\begin{array}{c}\text { FMI } \\
\text { Antigo }\end{array}$ & Holandês & $\begin{array}{c}\text { OCDE } \\
\text { Antigo }\end{array}$ & $\begin{array}{l}\text { FMI } \\
\text { Novo }\end{array}$ & $\begin{array}{c}\text { FMI } \\
\text { Novo - } \\
\text { Com } \\
\text { Quebras }\end{array}$ & $\begin{array}{l}\text { OCDE - } \\
\text { Novo }\end{array}$ & Média & $\begin{array}{c}\text { Primário } \\
\text { Oficial }\end{array}$ \\
\hline 2002 & $0.7 \%$ & $0.8 \%$ & $0.3 \%$ & $0.7 \%$ & $0.7 \%$ & $0.6 \%$ & $0.6 \%$ & $-0.7 \%$ \\
\hline 2003 & $-1.4 \%$ & $-1.3 \%$ & $-1.1 \%$ & $-1.7 \%$ & $-1.7 \%$ & $-1.6 \%$ & $-1.5 \%$ & $-0.4 \%$ \\
\hline 2004 & $-0.2 \%$ & $0.1 \%$ & $-0.6 \%$ & $-0.2 \%$ & $-0.2 \%$ & $-0.3 \%$ & $-0.2 \%$ & $-0.5 \%$ \\
\hline 2005 & $-0.4 \%$ & $-0.2 \%$ & $-0.3 \%$ & $-0.7 \%$ & $-0.7 \%$ & $-0.4 \%$ & $-0.4 \%$ & $-0.2 \%$ \\
\hline 2006 & $0.9 \%$ & $1.0 \%$ & $0.7 \%$ & $0.8 \%$ & $0.8 \%$ & $0.8 \%$ & $0.8 \%$ & $0.2 \%$ \\
\hline 2007 & $-0.2 \%$ & $0.0 \%$ & $-0.7 \%$ & $-0.1 \%$ & $-0.1 \%$ & $-0.2 \%$ & $-0.2 \%$ & $-0.3 \%$ \\
\hline 2008 & $-0.2 \%$ & $-0.2 \%$ & $0.1 \%$ & $-0.7 \%$ & $-0.7 \%$ & $-0.6 \%$ & $-0.4 \%$ & $-0.9 \%$ \\
\hline 2009 & $1.5 \%$ & $1.6 \%$ & $1.2 \%$ & $1.6 \%$ & $1.6 \%$ & $1.6 \%$ & $1.5 \%$ & $1.4 \%$ \\
\hline 2010 & $0.5 \%$ & $0.5 \%$ & $-0.1 \%$ & $0.5 \%$ & $0.5 \%$ & $0.5 \%$ & $0.4 \%$ & $-1.0 \%$ \\
\hline 2011 & $-0.9 \%$ & $-0.9 \%$ & $-0.9 \%$ & $-1.1 \%$ & $-1.1 \%$ & $-1.1 \%$ & $-1.0 \%$ & $-0.3 \%$ \\
\hline 2012 & $0.7 \%$ & $0.7 \%$ & $0.5 \%$ & $0.6 \%$ & $0.6 \%$ & $0.6 \%$ & $0.6 \%$ & $0.4 \%$ \\
\hline 2013 & $0.9 \%$ & $0.9 \%$ & $0.6 \%$ & $0.9 \%$ & $0.9 \%$ & $0.9 \%$ & $0.8 \%$ & $0.0 \%$ \\
\hline 2014 & $1.4 \%$ & $1.2 \%$ & $1.4 \%$ & $1.2 \%$ & $1.2 \%$ & $1.2 \%$ & $1.3 \%$ & $1.7 \%$ \\
\hline 2015 & $-0.3 \%$ & $-0.5 \%$ & $0.4 \%$ & $-0.8 \%$ & $-0.4 \%$ & $-0.7 \%$ & $-0.4 \%$ & $1.6 \%$ \\
\hline 2016 & $1.3 \%$ & $1.4 \%$ & $1.9 \%$ & $1.4 \%$ & $1.3 \%$ & $1.2 \%$ & $1.4 \%$ & $0.6 \%$ \\
\hline 2017 & $-0.2 \%$ & $-0.2 \%$ & $-0.2 \%$ & $0.0 \%$ & $-0.2 \%$ & $0.0 \%$ & $-0.1 \%$ & $-0.6 \%$ \\
\hline 2018 & $-0.5 \%$ & $-0.6 \%$ & $-0.8 \%$ & $-0.6 \%$ & $-0.7 \%$ & $-0.6 \%$ & $-0.6 \%$ & $0.0 \%$ \\
\hline
\end{tabular}

Fonte: Tesouro Nacional, Banco Central do Brasil.

Utilizando a metodologia de Função de Produção observamos que as mesmas conclusões que tiramos da metodologia do filtro HP também se aplicam, tendo, também, pequena variabilidade entre as metodologias do impulso fiscal, com exceção da metodologia antiga da OCDE. Assim como, a grande diferença em relação ao impulso que seria obtido apenas com a métrica oficial, além da deterioração observada de 2012 a 2016 e o impulso negativo para os últimos 2 anos.

Entretanto, apesar de em grande parte dos anos as diferentes formas de estimar o produto potencial apresentarem sinais semelhantes, a magnitude tende a diferir de forma significativa em alguns anos, como 2006, 2009, $2010 \mathrm{e}$ $2015^{13}$. Esse resultado é importante, pois demonstra que mais importante do que

${ }^{13}$ É importante notar que a maioria dos anos apresentados em que a diferença é maior, são aqueles em que houve crises econômicas. Portanto, nestes anos o hiato do produto via filtro HP e Função de Produção tendem a diferir de forma mais intensa, fazendo com que ocorra uma diferença significativa nos cálculos do impulso fiscal para estas métricas. 
a metodologia utilizada para o cálculo do impulso fiscal é a forma escolhida para estimar o produto potencial, podendo existir diferenças significativas em alguns anos.

Portanto, os resultados obtidos para o impulso fiscal demonstram que não há grande diferença entre as metodologias utilizadas na literatura, com exceção da metodologia antiga da OCDE. Entretanto, as maiores diferenças de magnitude estão presentes quando alteramos o método de estimação do produto potencial, sendo que o resultado desta medida difere significativamente em alguns anos. Além disso, fica clara a deterioração fiscal observada no país após a crise mundial, com impulsos fiscais positivos de 2012 a 2016, com exceção de 2015. Entretanto, nos dois últimos anos foram observados impulsos fiscais negativos indicando uma possível mudança na política fiscal. Por fim, as métricas de impulso fiscal indicam resultados muito diferentes do que se utilizássemos apenas a diferença para o resultado primário oficial.

Por fim, na tabela abaixo apresentamos uma decomposição entre os fatores que levaram a diferença entre o impulso calculado pelo primário oficial e a média das métricas utilizadas. 
Tabela 7: Decomposição da diferença entre o impulso fiscal pela métrica do primário oficial e a diferença entre a média das métricas obtidos por meio do filtro HP e Função de Produção

\begin{tabular}{|c|c|c|c|}
\hline & $\begin{array}{c}\text { Excluídas as operações } \\
\text { one-off e temporárias }\end{array}$ & $\begin{array}{c}\text { Ajuste ao ciclo e outros } \\
\text { ajustes - Filtro HP }\end{array}$ & $\begin{array}{c}\text { Ajuste ao ciclo e outros } \\
\text { ajustes - Função de } \\
\text { Produção }\end{array}$ \\
\hline 2002 & 0,8 & 0,1 & 0,4 \\
\hline 2003 & $-0,8$ & 0,3 & $-0,3$ \\
\hline 2004 & 0,1 & 0,2 & 0,3 \\
\hline 2005 & $-0,1$ & 0,0 & $-0,1$ \\
\hline 2006 & 0,1 & 0,0 & 0,5 \\
\hline 2007 & 0,1 & 0,1 & 0,1 \\
\hline 2008 & 0,1 & 1,1 & 0,3 \\
\hline 2009 & 0,6 & $-0,9$ & $-0,4$ \\
\hline 2010 & 0,3 & 0,6 & 1,0 \\
\hline 2011 & $-0,6$ & 0,1 & $-0,2$ \\
\hline 2012 & 0,1 & $-0,1$ & 0,1 \\
\hline 2013 & 0,5 & 0,2 & 0,3 \\
\hline 2014 & $-0,3$ & 0,2 & $-0,1$ \\
\hline 2015 & $-1,1$ & $-0,7$ & $-0,9$ \\
\hline 2016 & 1,1 & 0,0 & $-0,2$ \\
\hline 2017 & 0,5 & $-0,4$ & 0,0 \\
\hline 2018 & $-0,7$ & 0,0 & 0,0 \\
\hline
\end{tabular}

Fonte: Tesouro Nacional, Banco Central do Brasil.

Os resultados acima mostram que a maior parte da diferença entre os resultados do impulso fiscal calculado pelo primário oficial e da média de cada métrica de ajuste ao ciclo reside na diferença do primário recorrente. Em média, a diferença do primário recorrente corresponde a 0,7 pontos percentuais, enquanto que o ajuste ao ciclo e outros ajustes possui uma diferença de 0,5 pontos percentuais. Esse resultado corrobora a análise realizada na figura $6 \mathrm{em}$ que já havia um desvio significativo entre o primário oficial e o primário excluídas as operações one-off e temporárias.

\subsection{Conclusão}

A métrica de impulso fiscal é comumente utilizada em diversos países para analisar como a política fiscal está atuando sobre a demanda agregada da economia. Com isso, ela permite verificar ações pró-cíclicas e anticíclicas adotadas pelo governo federal. Entretanto, no caso brasileiro, diversos órgãos 
fazem uso de distintas metodologias para seu cálculo, obtendo, em alguns casos, resultados que levam a conclusões diferentes.

Neste ensaio, procuramos calcular o impulso fiscal, importante para demonstrar o comportamento da política fiscal ao longo dos anos, do Governo Central no Brasil por meio de seis metodologias distintas que foram utilizadas ao longo dos anos em diversos trabalhos empíricos, além de utilizarmos diferentes métricas de produto potencial.

Um ponto importante é que há uma série de ajustes necessários para o cálculo do impulso fiscal, sendo que o primeiro passo envolve a retirada das operações one-off e temporárias pois, como observado, no caso brasileiro estas operações são de significativa importância para o cálculo do impulso fiscal. Um passo intermediário para a obtenção do impulso fiscal para algumas metodologias envolve a estimação da elasticidade da arrecadação em relação ao PIB. Para esta métrica, fizemos uma série de ajustes que nos levaram a uma elasticidade próxima à unidade, resultado bem distinto daquele observado em estudos mais antigos sobre este tema.

Como resultado dos cálculos do impulso fiscal, observamos que para as diferentes metodologias utilizadas não se observa grande diferença entre os resultados ao longo dos anos, com exceção da metodologia antiga utilizada pela OCDE. Entretanto, a magnitude difere em alguns anos dependendo da metodologia utilizada para o cálculo do produto potencial, indicando que é importante buscar sempre a forma mais adequada de medir esta variável.

Outro ponto importante é que os resultados obtidos para o impulso fiscal diferem significativamente do resultado obtido para a variação do resultado primário oficial, indicando a importância da utilização desta métrica ajustada para a correta avaliação da política fiscal. Grande parte desta diferença está associada ao ajuste das operações one-off e temporárias, enquanto uma parte menor se deve ao ajuste ao ciclo e outros ajustes realizados para obtenção do impulso fiscal.

Por fim, os resultados apontam que de 2012 a 2016, com exceção de 2015, houve impulso fiscal positivo no país demonstrando a piora no padrão fiscal que acabaram levando a atual grave situação fiscal observada. Entretanto, 
nos últimos anos (2017 e 2018), observamos um impulso fiscal negativo, que pode indicar que está havendo uma tentativa de se reequilibrar a situação fiscal do país. 


\section{Estimação do nível máximo de endividamento para países emergentes}

\subsection{Introdução}

Como apresentado na introdução desta tese, o Brasil passou por um período de prosperidade na política fiscal, com redução contínua do nível de endividamento. Entretanto, com a mudança na postura da política fiscal, houve uma substancial piora no endividamento do país levando a atual trajetória de crescimento no endividamento.

Dívidas em trajetória ascendente e em patamares elevados, como o caso atual do Brasil, tem potencial de gerar desconfiança por parte dos credores quanto à capacidade futura de pagamento. Logo, como primeiro efeito, há uma elevação nos custos de captação e aumento no custo médio da dívida. A trajetória ascendente e o maior custo de captação aumentam ainda mais a desconfiança dos agentes causando um aumento maior no custo, e, por conseguinte, a uma probabilidade maior de default.

Este processo se repete diversas vezes até chegar um nível de endividamento em que os agentes já não mais creem que o governo está apto a arcar com as suas obrigações. Com isso, as taxas de juros exigidas no mercado alcançam um patamar que torna o financiamento da dívida impraticável, tirando a capacidade do governo de se financiar via dívida.

Essa piora na situação fiscal não foi um caso isolado do Brasil. Com a crise financeira, outros países emergentes também tiveram uma deterioração nas suas contas fiscais com pior resultado primário e maior endividamento, como apresentado na introdução desta tese.

Dentro deste contexto, este trabalho buscará estimar qual o nível máximo de endividamento e, consequentemente, o espaço fiscal que um grupo de 19 países emergentes pode suportar até que os agentes não consigam crer que o governo arcará com as suas obrigações.

Para isso, faremos uso do modelo de Ghosh et al. (2013) que estima uma função de reação fiscal para países desenvolvidos. Esta função descreve como o resultado primário responde a mudanças no endividamento e outras 
variáveis explicativas. Ela deverá apresentar a característica de fadiga fiscal, isto é, para níveis elevados de dívida a resposta do resultado primário se reduz. Assumiremos hipóteses sobre a taxa de juros para conseguirmos estabelecer 0 diferencial entre esta e crescimento econômico. Unindo-a com a função de reação fiscal alcançamos o nível máximo de endividamento que os países analisados podem atingir antes de entrarem em uma situação na qual não possam arcar com os compromissos da dívida (default). Para chegarmos a este limite, faremos uso tanto do conceito determinista quanto do conceito estocástico.

Como resultado, encontramos fortes evidências da existência de relação não linear entre o resultado primário e a defasagem do endividamento público exibindo a característica de fadiga fiscal. Assim como obtido por Ghosh et al. (2013), esta função pode ser aproximada por uma relação cúbica, em que conforme aumenta o nível do endividamento, aumenta a reação da política fiscal. Entretanto, a partir de um certo nível de endividamento, essa reação se enfraquece e, eventualmente, se reduz para níveis elevados de endividamento. Essa redução marginal se inicia a partir de níveis de endividamento em torno de $70 \%$ do PIB e se torna negativa a partir de $110 \%$ do PIB. São resultados bem diferentes do observado para países desenvolvidos em que a redução ocorre para níveis entre 90 e $100 \%$ do PIB e se torna negativa por volta de $150 \%$ do $\mathrm{PIB}$, sendo que mesmo para os limites superiores dos nossos intervalos de confiança a $95 \%$, os resultados para os países desenvolvidos são maiores. É importante ressaltar que a evidência de fadiga fiscal se mantem mesmo com o uso de diferentes técnicas de estimação, o uso de variáveis instrumentais para uma possível causalidade reversa entre resultado primário e endividamento e outras especificações.

Por fim, obtivemos níveis máximos de endividamento significativamente inferiores aos obtidos para países desenvolvidos nos casos determinista e estocástico. Para o primeiro caso, mesmo para os países que possuem os menores resultados de espaço fiscal, esses valores ainda são relativamente elevados. No segundo caso, em que tanto limite quanto o espaço são significativamente menores, observamos que, para grande parte dos países, a situação fiscal ainda é relativamente tranquila. Contudo, para Croácia e Brasil, o 
espaço fiscal é baixo, indicando a necessidade destes países realizarem ajustes em suas economias que propiciem a redução no seu nível de endividamento.

Nossa contribuição para a literatura pode ser dividida em três principais pontos: Primeiro, obtivemos um resultado que demonstra existir uma fadiga fiscal e um nível máximo de endividamento para países emergentes por meio de um modelo utilizado na literatura recente, mas que não havia sido utilizado anteriormente para países emergentes, provendo, empiricamente, importantes informações para os gestores de dívida pública dos países analisados. Segundo, nosso resultado de limite endividamento corrobora um fato esperado na prática: o nível máximo de endividamento obtido para os países emergentes é significativamente inferior ao observado para países desenvolvidos, como observado no resultado de Ghosh et al. (2013). Terceiro, replicamos, dentro do possível, a metodologia que Everaert e Jansen (2017) utilizam para criticar os resultados obtidos por Ghosh et al. (2013), além de outras técnicas de robustez, e observamos que nosso resultado se manteve mesmo para estas outras especificações.

Além disso, este trabalho busca contribuir do ponto de vista prático ao dar parâmetros aos formuladores de política pública de níveis de endividamento que poderiam colocar em risco a sustentabilidade da divida pública de seus países. Países como Polônia, Eslováquia e Armênia já adotam um limite de endividamento que, caso esse limite seja alcançado, uma série de medidas são adotadas para reduzi-la. Em especial, no Brasil é constitucionalmente previsto, mas não regulamentado um limite de endividamento e o tema é alvo de debate como uma possível regra fiscal que poderia vir a ser adotada no país, como apresentado em Brochado et al. (2019).

Este ensaio está dividido em cinco seções organizados da seguinte forma. Esta primeira seção introdutória em que apresentamos o principal objetivo deste ensaio. Na segunda seção apresentamos uma revisão de literatura com as principais metodologias utilizadas para estimação do limite de dívida e os resultados obtidos. Na terceira seção é apresentada a metodologia e a base de dados utilizada neste ensaio. Na quarta seção são apresentados os resultados e os exercícios de robustez da estimação e dos pressupostos assumidos no modelo. Por fim, na última seção há uma breve conclusão sobre os resultados obtidos. 


\subsection{Revisão de Literatura}

A estimação do nível máximo de endividamento é recente na literatura econômica e ganhou maior destaque após a crise de 2008, quando diversos países desenvolvidos alcançaram patamares elevadíssimos de endividamento e tiveram sua sustentabilidade questionada.

FMI (2003) propõe estimar o nível máximo de endividamento que um país pode alcançar estimando os valores de longo prazo para o superávit primário, a taxa de juros real e o crescimento do PIB. Estas variáveis podem ser obtidas por meio de processos de filtragem, como HP ou Kalman. Tendo estas variáveis, o nível máximo de endividamento seria aquele em que o país não consegue estabelecer um nível de superávit primário que estabilize a relação dívida/PIB.

Reinhart et al. (2003) analisam o limite de endividamento que um país emergente pode alcançar por meio do conceito de intolerância à dívida. Segundo os autores, que fazem parte da análise por meio de uma regressão em dados de painel, além dos fatores reputacionais, há o enfraquecimento das instituições devido à probabilidade de default, entrando em um ciclo vicioso em que esse enfraquecimento aumenta a probabilidade de default. Por fim, o nível máximo de endividamento varia de país para país e depende dos fatores históricos de cada um.

Garcia e Rigobon (2004) constroem um modelo estatístico que leva em consideração as relações estocásticas entre as variáveis que direta ou indiretamente influenciam a acumulação de dívida. Utilizando uma técnica de simulação que projeta a trajetória futura da razão dívida/PIB e por meio de simulações de Monte Carlo, os autores estimam o risco do endividamento superar um nível específico de dívida considerado arriscado. Com isso, os autores demonstram que a dívida no Brasil é sustentável. Entretanto, essa conclusão se altera no caso de algum choque negativo afetar a economia.

Celasun et al. (2006) propõe uma abordagem probabilística para análise da sustentabilidade da dívida por meio de modelos de fan charts. Os autores constroem um algoritmo de simulação para a dinâmica da dívida pública sob possíveis choques sobre a economia que podem combinar distúrbios das variáveis econômicas, reação da política fiscal a este distúrbio, e possíveis 
choques na política fiscal. Para isso, estimam a função de reação fiscal com base em dados em painel de países emergentes, depois estimam um VAR irrestrito com variáveis não fiscais que afetam a dinâmica da dívida pública e produzem projeções com base nos choques sobre a economia. Por fim, para cada grupo de choque é estimada uma dinâmica para o endividamento público. Unindo todo esse conjunto de choques e a reação da política fiscal, os autores criaram os fan charts para a dinâmica da dívida. Com isso, autores conseguem verificar a probabilidade do endividamento estar acima de um determinado nível.

Mendoza e Ostry (2008) observam a solvência fiscal e sustentabilidade da dívida pública em países emergentes e desenvolvidos. Os autores utilizam uma regressão em painel e encontram evidências de solvência fiscal. Entretanto, pontuam que essa evidência é mais fraca em países com endividamento elevado, não sendo possível rejeitar a hipótese de insolvência fiscal nesse grupo de países

Mendoza e Oviedo (2009) utilizam uma metodologia de equilíbrio geral que possibilita uma análise futura da razão dívida/PIB consistente com a solvência fiscal para um governo que está lidando com incertezas nas suas receitas e pode ter que lidar com um endividamento não contingente. Com isso, o governo deve respeitar um limite natural de endividamento. Esse limite natural estimado representa um comprometimento crível do país, estando ele apto a realizar o pagamento da sua dívida mesmo em períodos de crise fiscal. Caso o país ultrapasse este limite, não teria mais acesso ao mercado de crédito para rolar sua dívida. A análise é feita para Brasil, Colômbia, Costa Rica e México e a conclusão é que apesar destes países apresentarem um endividamento sustentável, o seu nível de endividamento corre risco em um contexto de baixo crescimento econômico e elevadas taxas de juros.

Medeiros (2012) utiliza um modelo de vetor autoregressivo (VAR) e um painel de função de reação fiscal para simular a razão de dívida para 15 membros da União Europeia. O resultado obtido mostra que o resultado primário apresenta "fadiga fiscal" e reversão parcial à tendência histórica.

Ghosh et al. (2013) utilizam um modelo estocástico de default soberano no qual investidores que são neutros ao risco emprestam ao governo que possui "fadiga fiscal", isto é, o esforço fiscal vai perdendo força conforme o nível de endividamento aumenta, tornando o superávit primário insuficiente para controlar 
a dívida em níveis elevados. Com isso, o governo possui um limite endógeno de endividamento sob o qual ele não consegue mais financiar sua dívida. Para chegar a este nível máximo de endividamento os autores, primeiramente, estimam a função de reação fiscal por meio de uma regressão de dados em painel para 23 países desenvolvidos no período de 1970 a 2007. Feito isso, calculam o diferencial entre taxa de juros e crescimento econômico que daria a dimensão do crescimento da razão dívida/PIB independentemente do nível de resultado primário. Unindo a função de reação fiscal com o diferencial, os autores chegam ao nível máximo de endividamento dos países e apresentam o conceito de "espaço fiscal", que seria a diferença entre o nível atual de endividamento destes países e o limite máximo que cada um poderia possuir.

Bi e Leeper (2013) buscam encontrar o limite fiscal dos países, isto é, o ponto em que por questões políticas ou econômicas impostos ou gastos não possam mais ser ajustados apara estabilizar a dívida. Por meio de um modelo de ciclos reais de negócios, os autores definem o ambiente econômico em uma distribuição para o nível máximo da razão dívida/PIB. A possibilidade de default é possível em qualquer ponto desta distribuição de limite fiscal.

Fall e Fournier (2015a) utilizam um modelo semelhante ao de Ghosh et al. (2013) para os países da OCDE. Estimam o nível máximo de endividamento destes países também por uma função de reação fiscal que apresenta a propriedade de "fadiga fiscal". Combinando esta função de reação fiscal com a taxa de juros associada ao crescimento da dívida, determinam o nível máximo de endividamento. A principal diferença em relação ao trabalho de Ghosh et al (2013) é que os autores já estabelecem os níveis de endividamento ex-ante por meio de simulação. A análise é feita para o período de 1985 a 2013 e mostra que diversos destes países podem estar com níveis elevados de endividamento graças a taxa de juros mais baixa. Além disso, mostram que, para alguns países, é necessária uma alteração no comportamento fiscal sob o risco de sua dívida ficar insustentável.

Fall e Fournier (2015b) buscam definir um nível sustentável de endividamento para países da OCDE e as regras fiscais específicas para cada um. Para atingir esse objetivo, os autores calculam um modelo macroeconômico semi-estrutural, similar à estrutura VAR e, por meio deste, obtêm as funções de reação fiscal. Os choques derivados destas estimações são utilizados para 
demonstrar a incerteza existente nas variáveis macroeconômicas. Por fim, os autores simulam o modelo até 2040 para derivarem o limite de endividamento para cada país e conseguir definir a melhor regra fiscal para cada um deles.

Bi et al. (2016) analisam o limite fiscal em países em desenvolvimento por meio de um modelo DSGE. A distribuição do limite fiscal, que mede a capacidade do governo de honrar com seus compromissos financeiros, é simulado com base na incerteza macroeconômica e a política fiscal. Os resultados mostram que as receitas futuras explicam de forma significativa os baixos limites fiscais encontrados para os países em desenvolvimento em comparação aos países desenvolvidos.

Everaert e Jansen (2017) analisam se a fadiga fiscal é uma característica robusta da função de reação fiscal em um painel para países da OCDE no período de 1970 a 2014. Para isso, na estimação em painel, os autores permitem dinâmicas, inclinações heterogêneas e reação assimétrica ao ciclo de negócios. Os resultados obtidos indicam que há uma reação heterogênea dos países e a fadiga fiscal não é uma característica geral compartilhada por todos os países no painel.

Checheria-Westphal e Zdarek (2017) analisam a função de reação fiscal para países da zona do euro. Os autores utilizam diversas técnicas de painel dinâmico e encontram que a evidência da reação do superávit primário a um nível de dívida maior aumentou no pós-crise. Esse resultado enfraquece a conclusão obtida por Ghosh et al. (2013), pois demonstra que a especificação de fadiga fiscal na função de reação fiscal é fraca.

Tran (2018) estima o limite da dívida para um grupo de 14 países emergentes durante o período de 1999-2016. Este limite seria o ponto que se excedido levaria o risco soberano para um nível insustentável. Para obter esse limite, é feita uma estimação de painel threshold. Como resultado, o autor obtém que as economias não pertencentes à América Latina são consideradas sustentáveis com seu débito abaixo do limite de 40-55\% do PIB. Para os países da América Latina, é estimado um limite em torno de $35 \%$ do PIB, demonstrando a necessidade dos países adotarem uma estrita disciplina fiscal para controlar seu endividamento, em muitos casos, superior ao limite obtido.

Portanto, há um grande interesse recente em metodologias que abordam o limite de endividamento e poucos resultados para países 
emergentes. Com isso, selecionamos uma metodologia recente, mas já bastante utilizada na literatura, para obtermos resultados para este grupo de países.

\subsection{Metodologia e Base de Dados}

Após termos apresentado uma revisão de literatura que demonstra como o tema de nível máximo de endividamento ganhou destaque recentemente, iremos, nesta seção, abordar a base de dados utilizada com os países e o período escolhido para a estimação. Além disso, apresentaremos o arcabouço teórico e a metodologia empírica para obtenção dos resultados.

\subsubsection{Base de Dados}

Para selecionarmos os países emergentes da nossa amostra partimos do Fiscal Monitor do FMI (2017) ${ }^{14}$, que seleciona 39 países classificados como emergentes e de renda média e abordam alguns indicadores fiscais destes países. Como um dos pressupostos importantes para o modelo é que os países possuem algum grau de homogeneidade ${ }^{15}$ em suas características, utilizamos os países indicados por este relatório para compormos nossa base de dados.

Destes 39 países, excluímos $5^{16}$ países da base de dados, devido a problemas nos seus dados. Posteriormente, destes 34 países restantes, excluímos 15 deles $^{17}$, pois o diferencial entre crescimento econômico e juros era

\footnotetext{
${ }^{14}$ A opção pelo estudo do FMI se deve ao fato de utilizarmos a base de dados desta instituição para obtermos a grande maioria dos indicadores utilizados na estimação da nossa função de reação fiscal. Além disso, como há uma grande dificuldade em definir quais países podem ser classificados como emergentes, preferimos seguir a recomendação desta instituição que possui amplo conhecimento na situação particular de cada país.

${ }^{15} \mathrm{~A}$ homogeneidade que estamos buscando aqui é utilizarmos países que possuam o maior número de características semelhantes, como, por exemplo, países emergentes com diferencial de juros e crescimento econômico positivo. Com isso, podemos estimá-los com menor receio de estarmos com uma amostra viesada.

${ }^{16}$ Foram excluídos os seguintes países: Venezuela, devido aos dados fiscais extremamente defasados (o último dado oficial para resultado primário é de 2013) e a baixa confiança nos dados oficiais; Líbia, pois o país não possui dados de dívida bruta; Qatar, pois não possui dados de inflação na base de dados; Bielorrússia, pois os dados de dívida só surgiram a partir de 2004, o que nos faria perder dois anos de observações; Argentina, pois não há dado de inflação nos anos de 2014, 2015 e 2016.

${ }^{17}$ Como critério para os países que farão parte da nossa amostra, manteremos os países que possuem: diferencial entre taxa de juros e crescimento econômico positivo; diferencial superior a $-3 \%$, que seria um nível próximo de reversão ou países em que esse diferencial tenha sido positivo na média dos últimos 3 anos da amostra (2013 a 2016).
} 
bastante negativo ${ }^{18}$ e, como apresentado por Carlin e Soskice (2014), quando este diferencial é negativo a dívida se estabiliza em um determinado ponto, independentemente do nível de endividamento. Com isso, nossas estimações serão realizadas para os seguintes 19 países: África do Sul, Argélia, Azerbaijão, Brasil, Colômbia, Croácia, República Dominicana, Emirados Árabes Unidos, Equador, Filipinas, Hungria, México, Marrocos, Omã, Peru, Polônia, Romênia, Turquia e Uruguai. ${ }^{19}$

Nossos dados se iniciam a partir de 2003 e vão até $2016^{20}$. Os dados são retirados do World Economic Outlook do FMl ${ }^{21}$ (2018) e do Banco Mundial (2018).

\subsubsection{Arcabouço Teórico e Metodologia Empírica}

Nesta subseção, mostraremos o arcabouço teórico da função de reação fiscal de forma resumida em relação ao apresentado por Ghosh et al. (2013).

Inicialmente, temos a restrição orçamentária do governo que demonstra a dinâmica da dívida pública:

$$
d_{t+1}-d_{t}=\left(r_{t}-g\right) d_{t}-s_{t+1}
$$

Em que $d_{t}$ é a dívida pública em porcentagem do PIB ao final do período t, $g$ é a taxa de crescimento real do produto, $s$ é o resultado primário do governo

\footnotetext{
${ }^{18}$ Este tema é abordado de maneira mais aprofundada no estudo de Escolano et al. (2011) que encontra este diferencial bem negativo para alguns países emergentes. Os autores observam, por meio de uma regressão com dados em painel, que o resultado baixo ou negativo para os países emergentes se deve a: severas distorções e repressão financeiras e ao nível de inflação estável, mas persistente. Esses fatores fazem com que estes países tenham taxas de juros anormalmente baixas. Além disso, eles apresentam crescimento econômico mais elevado que a média mundial. Portanto, esse diferencial tende a ser negativo por estes dois fatores: taxa de juros baixa e crescimento econômico elevado.

${ }^{19}$ Não é possível garantir que estes países correspondem a melhor amostra possível de países emergentes para nossa estimação e podem surgir críticas com relação à inclusão ou exclusão de algum país. Para minimizarmos estas críticas, preferimos não seguir um padrão próprio para a seleção dos países, mas, sim, a seleção realizada pelo FMI que possui um nível de conhecimento muito superior ao nosso sobre as características de cada país.

${ }^{20}$ Este é o último em que há dados oficiais para todos os países. A partir de 2017, não possuímos valores para as variáveis de controle de alguns países.

${ }^{21}$ É importante notar que utilizamos os indicadores de endividamento do FMI pelo fato de possuir um padrão único que, de certa forma, torna o endividamento comparável entre os países. Entretanto, admitimos que os números do FMI nem sempre serão os mesmos que os países consideram para sua política fiscal, como o caso do Brasil em que os valores de endividamento brasileiro são inferiores ao do FMI devido à forma distinta de contabilização dos títulos públicos em posse do Banco Central e a dívida das empresas estatais, como apresentado em Ministério da Economia (2019).
} 
como porcentagem do produto e $r_{t}$ é a taxa de juros real que impactará a dívida no período $t+1$. Para a derivação do modelo, os autores assumem que $g$ é exógeno, enquanto $r$ é assumida como endógena e maior ou igual à taxa de juros livre de risco $r^{*}$, a qual assume-se ser exógena.

A equação (1) demonstra que a variação da dívida em $t+1$ depende do resultado primário em $t+1$, do diferencial entre taxa de juros e crescimento real do PIB e do nível de endividamento.

Para seguir com a derivação do modelo, são impostas três hipóteses:

Hipótese 1: Função de reação fiscal sob fadiga fiscal

A função de reação fiscal é dada por:

$s_{t+1}=\mu+f\left(d_{t}\right)+\varepsilon_{t+1}$

Em que $\mu$ capta todas as variáveis que influenciam o resultado primário, com exceção da defasagem da dívida, $f(d)$ é a resposta do resultado primário à defasagem da dívida, a qual assume-se ser contínua e continuamente diferenciável e $\varepsilon$ é o choque do resultado primário, o qual assume-se ser independente e identicamente distribuído com a função distribuição $G(\varepsilon)$ definida sob o suporte finito $[-\bar{\varepsilon}, \bar{\varepsilon}]$, com $\bar{\varepsilon}>0$.

Para capturar a ideia da fadiga fiscal, os autores assumem que existe um nível de endividamento $d^{m}>\bar{\varepsilon}$ tal que

$$
\mu+f\left(d^{m}\right)-\bar{\varepsilon} \geq\left(r^{*}-g\right) d^{m} \text { e } f^{\prime}(d)<r^{*}-g, \forall d>d^{m}
$$

Com isto, para qualquer nível de endividamento maior que $d^{m}$ a resposta do resultado primário é inferior ao diferencial entre taxa de juros e crescimento.

Hipótese 2: A regra de default

A situação em que o governo não consegue arcar com seu compromisso de dívida (default) ocorre se e somente se a dívida excede o limite $\bar{d}$, que é definido como o nível máximo de endividamento que o governo pode arcar a um nível finito de taxa de juros.

Com isso, podemos partir para a seguinte função indicadora:

$$
D_{t+1}=\left\{\begin{array}{lr}
1 & \text { se } d_{t+1}>\bar{d} \\
0 & \text { caso contrário }
\end{array}\right.
$$

Se a função assume valor 1, então o país estará em situação de default e 0 , caso contrário. Na situação em que o país está acima de $\bar{d}$, o endividamento 
torna-se explosivo, com isso, o governo não terá mais acesso ao mercado de dívida, a taxa de juros solicitada pelos credores será infinita e o país estará em situação de default.

Hipótese 3: Credores neutros ao risco

Por fim, os autores elaboram essa última hipótese assumindo que sob ela:

i. Há uma probabilidade inferior a um que o endividamento do governo está em trajetória explosiva

ii. Há uma taxa de juros finita que compensa os emprestadores neutros ao risco pelo risco de default:

$$
1+r^{*}=\left(1-\rho_{t+1}\right)\left(1+r_{t}\right)+\rho_{t+1} \theta\left(1+r^{*}\right)
$$

Em que $\rho_{t+1}$ é a probabilidade de default no próximo período e $\theta$ é o valor recuperado em um eventual default.

iii. Se houver múltiplas taxas de juros que satisfazem a condição acima, assumimos que os credores escolherão a menor delas.

As três hipóteses apresentadas acima são suficientes para garantir a existência do limite de dívida $\bar{d}$.

Para resolver o caso determinista, em que ao atingir o nível máximo de endividamento a taxa de juros se torna infinita, temos que ele deve ser a maior raiz da seguinte equação:

$$
\mu+f(\bar{d})=\left(r^{*}-g\right) \bar{d}
$$

Enquanto ambos os lados de (6) aumentam em $d$, por (3), o lado esquerdo da equação cresce mais lentamente que o direito por $d>d^{m}$. Logo, como sob $\bar{d}$, o resultado primário nunca é suficiente para arcar com o pagamento de juros, a dívida cresce continuamente e o governo estará em situação de default.

Com isso, é apresentada a figura abaixo que apresenta a relação da função de reação fiscal do resultado primário com o diferencial entre taxa de juros e taxa de crescimento do produto. 
Figura 7: Determinação do Limite de dívida

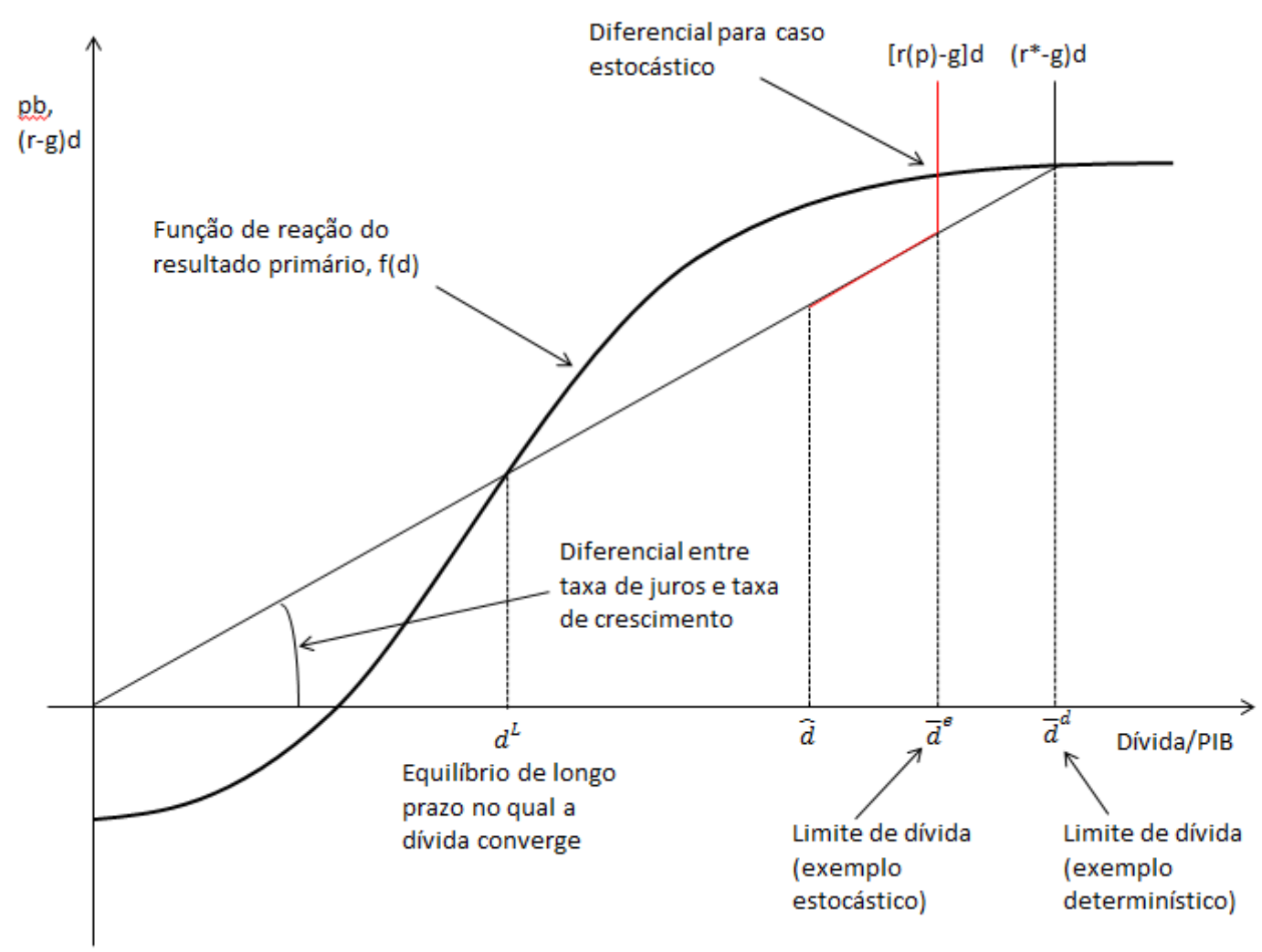

Fonte: Ghosh et al (2013). Elaboração própria.

Como é possível observar, para o caso determinista há dois pontos em que a reta de diferencial de juros e crescimento corta a função de reação fiscal. No ponto de endividamento mais baixo, que chamamos de $d^{L}$, é ponto de longo prazo da dívida que a economia converge condicionalmente ${ }^{22}$.

No segundo ponto, que chamamos de $\bar{d}^{d}$, temos o limite de dívida, que é ponto no qual, a partir dele, não há resultado primário suficiente para arcar com as despesas de juros; e, com isso, a taxa de juros exigida pelos credores é infinita e o país entra em uma situação de default.

Para o caso estocástico, que tem sua representação teórica apresentada no Anexo $A .1^{23}$, temos o nível de dívida $\hat{d}$, que é o nível em que o mercado começa a acreditar na possibilidade do governo entrar em situação de default. Portanto, conforme o nível de endividamento aumenta, o risco de default percebido pelos agentes também aumenta. Com isso, o mercado exigirá uma

\footnotetext{
${ }^{22}$ Ghosh et al. (2013) mostram que este ponto é dinamicamente estável.

${ }^{23}$ Neste anexo resumimos as derivações realizadas por Ghosh et al (2013) em seu apêndice A.
} 
taxa de juros maior e se torna menos provável que o governo consiga arcar com as despesas de juros. Logo, aumenta a probabilidade de default, que aumenta a taxa de juros, até chegarmos ao ponto $\bar{d}^{e}$ em que o país entra em situação de default.

Por fim, é importante notar que uma redução do crescimento econômico ou aumento da taxa de juros diminui o nível de endividamento máximo. Assim como um maior comprometimento no resultado primário levará a um deslocamento para cima da função de reação fiscal e, consequentemente, aumento no nível máximo de endividamento.

Para a implementação empírica deste modelo serão seguidos estes três passos:

i. Estimação da função de reação fiscal;

ii. Determinar o diferencial entre taxa de juros e taxa de crescimento;

iii. Calcular o limite de endividamento e o espaço fiscal associado, que seria a diferença entre o atual nível de endividamento e o limite de endividamento calculado.

Para o cálculo da função de reação fiscal, faremos uma regressão com dados em painel com efeito fixo para os 19 países emergentes selecionados anteriormente no período entre 2003 e 2016. Nossa regressão consiste do resultado primário dos países sendo explicado pela defasagem da dívida bruta e outras variáveis de controle como apresentado no modelo abaixo.

$$
p b_{i, t}=\alpha_{i}+\beta_{1} d_{i, t-1}+\beta_{2} d_{i, t-1}^{2}+\beta_{3} d_{i, t-1}^{3}+\gamma Z_{i, t}+\varepsilon_{i, t}
$$

Em que $p b_{i, t}$ é o resultado primário do país i no período $\mathrm{t}, d_{i, t-1}$ é o endividamento bruto do país i defasado, $Z_{i, t}$ são as outras variáveis de controle do modelo e $\alpha_{i}$ é o efeito fixo de cada país i invariante no tempo que não está nas outras variáveis de controle

Na nossa regressão, a defasagem da dívida bruta explica o resultado primário em nível, no formato quadrático e no formato cúbico. A significância estatística do formato cúbico negativo $\left(\beta_{3}<0\right)$ ou a significância estatística e valor negativo do formato quadrático $\left(\beta_{2}<0\right)$ e não significância estatística do formato cúbico $\left(\beta_{3}=0\right)$ seriam indicativos de há fadiga fiscal para níveis elevados de endividamento. 
Para as variáveis de controle utilizamos as mesmas variáveis de Ghosh et al. (2013), que se baseiam em uma extensa literatura sobre quais variáveis explicam o resultado primário. Além destes, analisamos trabalhos mais recentes como de D'Erasmo et al. (2015) e Berti et al. (2016), que corroboraram a escolha das variáveis. É utilizado o hiato do produto para controlar para os efeitos de flutuação do produto; uma variável de hiato dos gastos para controlar possíveis aumentos ou reduções temporárias de gastos ${ }^{24}$; abertura comercial; taxa média de inflação dos últimos três anos para controlar para possíveis efeitos inflacionários sobre a arrecadação; o resultado em conta corrente do país em \% do PIB, sendo esta a única adição em relação ao utilizado por Ghosh et al. (2013) e sua adição se justifica pelo fato de o desequilíbrio em conta corrente ser uma importante fonte de default em países emergentes, como apresentado por Krugman et al. (2015); log do preço de petróleo para países exportadores de petróleo ${ }^{25}$ e log do preço das commodities ex-petróleo para países que não são exportadores de petróleo; razão de dependência para controlarmos para possíveis alterações na estrutura etária dos países. Além destas, controlamos para variáveis institucionais como um índice de estabilidade política calculado pelo Worldwide Governance Indicators que calcula o indicador com base em dados que poderiam indicar possíveis riscos de estabilidade política ${ }^{26}$; uma variável dummy que assume valor igual a 1 se o país possui algum tipo de regra fiscal ${ }^{27}$ e 0 caso contrário em um determinado ano; e uma variável dummy que possui valor igual a 1 se o país obteve algum suporte financeiro do FMI e 0 caso contrário em um determinado $\mathrm{ano}^{28}$.

Abaixo, apresentamos uma tabela com as estatísticas descritivas da nossa base de dados para o conjunto de países.

\footnotetext{
${ }^{24}$ Para calcularmos o hiato, utilizamos o filtro HP tanto para o cálculo do hiato do produto quanto para o hiato dos gastos.

${ }^{25}$ A classificação dos países exportadores de petróleo é realizada por FMI (2017a).

${ }^{26}$ Este indicador varia de 0 (pior estabilidade política) até 5 (melhor estabilidade política).

${ }^{27}$ Esse indicador é calculado pelo FMl e indica se o país possui alguma regra fiscal para gastos, receita, orçamento ou dívida.

${ }^{28}$ Para todas as variáveis utilizadas foram realizados testes de raiz unitária e para todas as variáveis rejeitamos a hipótese de presença de raiz unitária em nossos dados.
} 
Tabela 8: Estatísticas Descritivas

\begin{tabular}{|c|c|c|c|c|c|c|c|c|c|c|c|c|c|}
\hline & Primário & Dívida & $\begin{array}{l}\text { Hiato do } \\
\text { produto }\end{array}$ & $\begin{array}{c}\text { Hiato } \\
\text { dos } \\
\text { Gastos }\end{array}$ & $\begin{array}{l}\text { Abertura } \\
\text { Comercial }\end{array}$ & Inflação & $\begin{array}{l}\text { Conta } \\
\text { Corrente }\end{array}$ & $\begin{array}{l}\text { Preço do } \\
\text { petróleo }\end{array}$ & $\begin{array}{l}\text { Razão de } \\
\text { dependência }\end{array}$ & $\begin{array}{l}\text { Preço das } \\
\text { commodities }\end{array}$ & $\begin{array}{c}\text { Índice de } \\
\text { Estabilidade } \\
\text { Política }\end{array}$ & $\begin{array}{c}\text { Auxílio } \\
\text { FMI }\end{array}$ & $\begin{array}{l}\text { Regra } \\
\text { Fiscal }\end{array}$ \\
\hline Média & 0.84 & 39.76 & 0.28 & 0.56 & 73.98 & 5.33 & -0.19 & 4.27 & 49.99 & 4.89 & 2.80 & 0.26 & 0.46 \\
\hline 10 Quartil & -1.50 & 22.47 & -0.99 & -3.47 & 52.53 & 2.75 & -4.41 & 3.96 & 45.59 & 4.68 & 2.17 & 0.00 & 0.00 \\
\hline Mediana & 0.55 & 38.79 & 0.41 & 0.06 & 65.46 & 4.46 & -1.51 & 4.32 & 51.47 & 4.92 & 2.79 & 0.00 & 0.00 \\
\hline 30 Quartil & 2.71 & 54.28 & 1.75 & 3.39 & 85.14 & 6.37 & 1.77 & 4.64 & 56.59 & 5.10 & 3.61 & 1.00 & 1.00 \\
\hline Desvio padrão & 4.78 & 21.49 & 3.11 & 8.27 & 33.24 & 4.69 & 8.01 & 0.44 & 10.00 & 0.25 & 0.83 & 0.44 & 0.50 \\
\hline Variância & 22.89 & 461.99 & 9.67 & 68.33 & 1104.84 & 22.02 & 64.12 & 0.19 & 100.01 & 0.06 & 0.69 & 0.19 & 0.25 \\
\hline Mínimo & -21.64 & 3.60 & -9.89 & -23.15 & 22.11 & -0.60 & -29.82 & 3.36 & 16.45 & 4.41 & 0.63 & 0.00 & 0.00 \\
\hline Máximo & 20.15 & 111.55 & 21.05 & 48.06 & 176.75 & 41.57 & 33.59 & 4.93 & 69.75 & 5.25 & 4.13 & 1.00 & 1.00 \\
\hline
\end{tabular}

Fonte: FMI e Banco Mundial

É importante notar que os valores mais extremos observados nas variáveis estão relacionados aos países exportadores de petróleo, que possuem grande parte de sua arrecadação vinculada à produção e preço desta commodity.

A opção pela estimação do método de feito fixo se deve ao fato que há variáveis explicativas do resultado primário que estão correlacionadas com o nível de endividamento defasado. Como exemplo, países que possuem efeitos fixos não observados e que influenciam positivamente o resultado primário terão, como consequência, níveis menores de endividamento.

Outro possível problema surge no fato de que há persistência no termo de erro e isso poderia levar a um problema de endogeneidade no endividamento defasado. Para resolver isto, modelamos o termo de erro $\left(\varepsilon_{i, t}\right)$ como um $\operatorname{AR}(1)$, permitindo, assim, correlação serial no termo de erro. Com isso, nosso termo de terá o seguinte formato: $\varepsilon_{i, t+1}=\rho \varepsilon_{i, t}+\vartheta_{t}$.

A partir deste formato apresentado acima, conseguimos cumprir 0 primeiro passo empírico que consiste no cálculo da função de reação fiscal e verificarmos a possível presença da fadiga fiscal. Em seguida, partimos para o segundo passo que consiste no cálculo do diferencial entre taxa de juros e crescimento econômico.

\subsubsection{Cálculo do Diferencial entre Juros e Crescimento Econômico}

Para o cálculo deste diferencial partiremos de duas metodologias distintas. Na primeira metodologia calcularemos, primeiramente, o total de juros 
pago pelos países com base na diferença entre o resultado nominal e resultado primário dos países. Com isso, chegamos ao juro líquido pago pelos países e o dividimos pelo endividamento líquido ${ }^{29}$. Para o cálculo da taxa de crescimento, fazemos a taxa de crescimento nominal do PIB dos países. Por fim, para chegarmos ao diferencial entre taxa de juros e crescimento, subtraímos da taxa de juros a taxa de crescimento do produto e fazemos a média deste resultado para os últimos 11 anos para cada país observado.

Outra forma de chegarmos ao diferencial entre juros e crescimento econômico é obtermos a taxa de juros líquido pagos dos países pelo método acima. Posteriormente, calculamos a taxa de juros estrutural por meio da metodologia apresentado em Segura-Ubiergo (2012) em que calculamos um painel pelo modelo de correção de erros da seguinte forma:

$$
\Delta R_{i, t}=\alpha+\gamma R_{i, t-1}+\beta_{k} \Delta \mathrm{X}_{\mathrm{i}, \mathrm{t}-1}+\beta_{j} X_{i, t-1}+\epsilon_{i, t}
$$

Em que $R_{i, t}$ é a variável de juros líquido, enquanto nas variáveis independentes temos o logaritmo do PIB per capita, o resultado em conta corrente em \% do PIB, poupança em \% do PIB, resultado primário em \% do PIB, a taxa de juros do governo americano, a volatilidade da inflação e uma dummy para quando o país possui regime de metas de inflação.

Para o obtermos o produto potencial, utilizamos o crescimento real dos países com as projeções calculadas pelo FMI (2018) até 2024 e utilizamos o filtro HP para obtermos o produto potencial. Com isso, tendo o resultado do juro estrutural e do produto potencial, utilizamos o resultado do último período da nossa amostra, 2016, e obtemos o valor do diferencial entre taxa de juros e crescimento econômico.

Por fim, tendo a função de reação fiscal estimada e projetada para cada país por meio dos valores médios das variáveis explicativas. Tendo calculado o diferencial entre taxa de juros e crescimento pelas duas metodologias apresentadas acima, conseguimos obter o limite máximo de endividamento para cada país e seu respectivo espaço fiscal, que corresponde à diferença entre 0 nível atual de endividamento e seu limite.

\footnotetext{
${ }^{29}$ Para esta variável, utilizamos o World Economic Outlook divulgado em outubro de 2017, pois em 2018, houve uma alteração na metodologia de apuração deste dado por parte do FMI que fez com que muitos países não tivessem seus resultados disponíveis.
} 


\subsection{Resultados}

\subsubsection{Estimação da Função de Reação Fiscal}

Após termos apresentado, na seção anterior, a metodologia tanto teórica quanto empírica na qual nosso trabalho está embasado e a base de dados utilizada, apresentaremos, nesta seção, os resultados obtidos para a função de reação fiscal, o diferencial entre juros e crescimento e, por fim, o limite de endividamento.

Na tabela abaixo são apresentamos os resultados da função de reação fiscal para o conjunto de 19 países e dados de 2003 a 2016 estimando-se por efeito fixo com estrutura $A R(1)$ no termo de erro. 
Tabela 9: Estimação da Função de Reação Fiscal

\begin{tabular}{|c|c|c|}
\hline Variáveis & Estimação I & Estimação II \\
\hline Dívida defasada & $\begin{array}{c}-0,4153347^{* *} \\
(0,1707535)\end{array}$ & $\begin{array}{c}-0,3286141^{\star *} \\
(0,133331)\end{array}$ \\
\hline Dívida defasada ao quadrado & $\begin{array}{l}0,0081495^{\star *} \\
(0,0035358)\end{array}$ & $\begin{array}{r}0,0074287^{* *} \\
(0,0027696)\end{array}$ \\
\hline Dívida defasada ao cubo & $\begin{array}{l}-0,0000425^{\star} \\
(0,0000221)\end{array}$ & $\begin{array}{c}-0,0000367^{* *} \\
(0,0000173)\end{array}$ \\
\hline Hiato do produto & $\begin{array}{l}0,2147907^{\star \star *} \\
(0,0585075)\end{array}$ & $\begin{array}{c}0,1890443^{* * *} \\
(0,0523639)\end{array}$ \\
\hline Hiato dos gastos do governo & $\begin{array}{l}-0,0116813 \\
(0,0203748)\end{array}$ & $\begin{array}{c}-0,0348892^{* *} \\
(0,0170306)\end{array}$ \\
\hline Abertura Comercial & & $\begin{array}{c}0,360213 \\
(0,0292016)\end{array}$ \\
\hline Conta Corrente & & $\begin{array}{c}0,3454835^{\star \star *} \\
(0,0548622)\end{array}$ \\
\hline Inflação & & $\begin{array}{c}0,066361 \\
(0,0707233)\end{array}$ \\
\hline Preço do petróleo & & $\begin{array}{c}4,505554^{\star * *} \\
(1,039627)\end{array}$ \\
\hline Razão de Dependência & & $\begin{array}{l}-0,724689^{* * *} \\
(0,1620734)\end{array}$ \\
\hline $\begin{array}{l}\text { Preço de Commodities ex- } \\
\text { Petróleo }\end{array}$ & & $\begin{array}{c}3,492755^{\star \star} \\
(1,54124)\end{array}$ \\
\hline Estabilidade Política & & $\begin{array}{l}-0,5127073 \\
(0,827262)\end{array}$ \\
\hline Suporte Financeiro do FMI & & $\begin{array}{l}0,0707904 \\
(0,75956)\end{array}$ \\
\hline Regra Fiscal & & $\begin{array}{l}-0,5042835 \\
(1,125135)\end{array}$ \\
\hline Constante & $\begin{array}{l}5,153874^{\star * *} \\
(0,8810565)\end{array}$ & $\begin{array}{c}-48,61157^{\star * *} \\
(4,089996)\end{array}$ \\
\hline Coeficiente AR(1) & 0,66641238 & 0,60079262 \\
\hline Número de Observações & 247 & 247 \\
\hline$R^{2}$ & 0,0892 & 0,4779 \\
\hline Teste F & 4,37 & 13,99 \\
\hline
\end{tabular}

Fonte: Elaboração própria

Nota: Os valores com $\left({ }^{*}\right)$ indicam que rejeitamos a hipótese nula a 10\%, valores com $\left(^{* \star}\right)$ indicam que rejeitamos a hipótese nula a $5 \%$, valores com $\left(^{* * *}\right)$ indicam que rejeitamos a hipótese nula a 1\%. Erro-padrão em ().

Como é possível observar para a estimação I, há evidências de fadiga fiscal para o conjunto de países emergentes selecionados, pois todos os coeficientes que medem a reação do resultado primário ao endividamento são estatisticamente diferentes de zero. Além disso, percebemos que o hiato do produto é a variável de controle estatisticamente significante explicando o resultado primário dos países. 
Para a estimação II, na qual adicionamos outras variáveis explicativas para o resultado primário, encontramos evidências de fadiga fiscal para os países emergentes selecionados, pois todos os coeficientes que medem a reação do resultado primário são estatisticamente significantes e possuem o sinal esperado. Com base nos coeficientes estimados, a resposta marginal do resultado primário começa a diminuir com níveis de endividamento em torno de $70 \%$ do PIB, tornando-se negativo para níveis de endividamento próximos a $110 \%$ do PIB. Estes resultados são interessantes, pois mostram, como esperado, que países emergentes possuem diminuição de resposta marginal e resposta negativa do resultado primário inferiores àquelas observadas nos países desenvolvidos que possuem este resultado para níveis de endividamento entre 90 e $100 \%$ do PIB e $150 \%$ do PIB para o primeiro e o segundo, respectivamente, conforme resultado obtido por Ghosh et al. (2013).

Além disso, a magnitude de $70 \%$ do PIB em que a resposta marginal do superávit primário começa a se reduzir é similar ao resultado obtido por FMI (2003) que, utilizando o modelo de Bohn (1998) para uma série de países emergentes, obteve que a resposta do superávit primário ao endividamento se enfraquece e, eventualmente, se reduz para quando o endividamento atinge $50 \%$ do PIB.

Além da evidência de fadiga fiscal, as outras variáveis explicativas possuem resultados que estão de acordo com a teoria econômica. Há um aumento do resultado primário dos países quando o hiato é positivo; aumento de gastos acima do nível tendencial diminuem o resultado primário; aumentos no resultado em conta corrente aumentam o resultado primário do país; aumento no preço do petróleo, para países exportadores de petróleo, e aumento no preço das commodities ex-petróleo, para países não exportadores de petróleo, aumentam o resultado primário dos países ${ }^{30}$; um aumento na razão de dependência reduz o resultado primário dos países, fato este que pode estar associado a maiores despesas com aposentadoria. Por fim, nenhuma das

\footnotetext{
${ }^{30}$ Esse resultado demonstra que os países emergentes podem ter parte de suas receitas indexadas às commodities e o aumento no preço das commodities exportadas possui efeito positivo sobre o crescimento econômico, conforme demonstrado por Deaton e Miller (1996), Dehn (2000), Collier e Goderis (2012) e Cavalcanti et al (2014). Isso ajuda, também, a explicar porque a significância do hiato do produto diminuiu da estimação I para a estimação II.
} 
variáveis institucionais possui efeito estatisticamente significante sobre 0 resultado primário, assim como abertura comercial e inflação ${ }^{31}$.

Com isso, observamos que, para nossa regressão principal, o resultado de fadiga fiscal é empiricamente observado e os níveis de endividamento que ela acontece são significativamente inferiores ao observado para países desenvolvidos. Na próxima subseção iremos verificar se nosso resultado é robusto a outras metodologias de estimação e se a hipótese de homogeneidade da função de reação fiscal é factível.

\subsubsection{Robustez da função de reação fiscal, da hipótese de homogeneidade e problema de causalidade reversa}

Após termos apresentado evidências da existência da fadiga fiscal para países emergentes, iremos, nesta subseção, verificar se este resultado se mantem para diferentes métodos de estimação. Além disso, realizaremos uma estimação para a mesma especificação realizada por Everaert e Jansen (2017), que a utilizam para criticar os resultados obtidos por Ghosh et al. (2013). Por fim, como a hipótese de homogeneidade é importantíssima para garantir que a função de reação fiscal obtida seja válida para todos os países, faremos análises individuais que garantam isto, além de analisarmos se, sob um possível problema de causalidade reversa, qual seria o resultado com o uso de variáveis instrumentais.

Primeiramente, estimaremos a função de reação fiscal com base na especificação II por diferentes metodologias como: (1) a metodologia mais simples de estimação em painel, MQO Agrupado; (2) uma estimação por efeito fixo, mas sem o componente autoregressivo no termo de erro; (3) estimação por efeito fixo sem o componente autoregressivo no termo de erro e com variável dummy para cada ano (efeito do tempo); (4) estimação por efeito fixo com o componente autoregressivo no termo de erro e com variável dummy para cada

\footnotetext{
${ }^{31}$ Como forma de robustez, fizemos estas mesmas regressões incluindo os países que possuem diferencial entre crescimento econômico e juros bem negativo e os resultados obtidos foram muito semelhantes aos obtidos nestas regressões, inclusive com a resposta marginal e o ponto de reversão da resposta do resultado primário estando em torno $70 \%$ e $110 \%$, respectivamente. Esse resultado afasta uma das críticas de Medeiros (2012) que indicou que os resultados obtidos para a fadiga fiscal eram dependentes da amostra selecionada.
} 
ano (efeito do tempo); (5) Correção para correlação serial e possibilidade de dependência do corte transversal no termo de erro.

Tabela 10: Testes de robustez para a estimação da função de reação fiscal

\begin{tabular}{|c|c|c|c|c|c|}
\hline Variáveis & $\begin{array}{c}\text { MQO } \\
\text { Agrupado } \\
\text { (1) }\end{array}$ & $\begin{array}{l}\text { Efeito Fixo } \\
\text { sem AR } \\
\text { (2) }\end{array}$ & $\begin{array}{l}\text { Efeito Fixo } \\
\text { sem AR } \\
\text { (3) }\end{array}$ & $\begin{array}{l}\text { Efeito } \\
\text { Fixo com } \\
\text { AR (4) }\end{array}$ & $\begin{array}{l}\text { PCSE } \\
\text { (5) }\end{array}$ \\
\hline Dívida defasada & $\begin{array}{l}-0,20215^{\star *} \\
(0,09538)\end{array}$ & $\begin{array}{c}-0,2853^{* \star *} \\
(0,0895)\end{array}$ & $\begin{array}{l}-0,1450 \\
(0,0904)\end{array}$ & $\begin{array}{l}-0,2474^{* *} \\
(0,1246)\end{array}$ & $\begin{array}{l}-0,1478^{\star \star} \\
(0,0721)\end{array}$ \\
\hline $\begin{array}{c}\text { Dívida defasada } \\
\text { ao quadrado }\end{array}$ & $\begin{array}{c}0,0043^{* *} \\
(0,002)\end{array}$ & $\begin{array}{r}0,0062^{* \star *} \\
(0,0036)\end{array}$ & $\begin{array}{l}0,0043^{*} \\
(0,0023)\end{array}$ & $\begin{array}{l}0,0053^{* *} \\
(0,0025)\end{array}$ & $\begin{array}{l}0,0033^{\star *} \\
(0,0015)\end{array}$ \\
\hline Dívida defasada & $-0,00002^{* *}$ & $-0,00004^{* *}$ & $-0,00003^{*}$ & $-0,00003^{*}$ & $-0,00002^{* *}$ \\
\hline $\begin{array}{c}\text { ao cubo } \\
\text { Hiato do produto }\end{array}$ & $\begin{array}{c}(0,00001) \\
0,32969^{\star \star \star} \\
(0,07669)\end{array}$ & $\begin{array}{l}(0,00001) \\
0,2627^{\star \star \star} \\
(0,0654)\end{array}$ & $\begin{array}{l}(0,0001) \\
0,1783^{* *} \\
(0,0847)\end{array}$ & $\begin{array}{c}(0,0002) \\
0,0784^{*} \\
(0,0556)\end{array}$ & $\begin{array}{c}(0,00001) \\
0,1937^{\star *} \\
(0,0816)\end{array}$ \\
\hline Hiato dos gastos & 0,022220 & 0,01653 & $-0,0094$ & $-0,0505^{\star * *}$ & $-0,227$ \\
\hline do governo & $(0,035884)$ & $(0,0238)$ & $(0,0199)$ & $(0,0155)$ & $(0,0276)$ \\
\hline $\begin{array}{l}\text { Abertura } \\
\text { Comercial }\end{array}$ & $\begin{array}{l}-0,02825^{\star * \star} \\
(0,006893)\end{array}$ & $\begin{array}{l}-0,03268 \\
(0,04040)\end{array}$ & $\begin{array}{l}-0,0561 \\
(0,0383)\end{array}$ & $\begin{array}{l}-0,0266 \\
(0,0288)\end{array}$ & $\begin{array}{l}-0,0338^{\star *} \\
(0,0040)\end{array}$ \\
\hline Conta Corrente & $\begin{array}{c}0,522362^{* * *} \\
(0,081808)\end{array}$ & $\begin{array}{c}0,35112^{* \star} \\
(0,1270)\end{array}$ & $\begin{array}{l}0,4344^{* * *} \\
(0,1299)\end{array}$ & $\begin{array}{l}0,4215^{\star * *} \\
(0,0513)\end{array}$ & $\begin{array}{c}0,5443^{* * *} \\
(0,0533)\end{array}$ \\
\hline Inflação & $\begin{array}{l}0,088335^{*} \\
(0,050609)\end{array}$ & $\begin{array}{l}0,05647 \\
(0,0782)\end{array}$ & $\begin{array}{c}0,0536 \\
(0,0759)\end{array}$ & $\begin{array}{c}0,0313 \\
(0,0667)\end{array}$ & $\begin{array}{c}0,0626 \\
(0,3814)\end{array}$ \\
\hline $\begin{array}{l}\text { Preço do } \\
\text { petróleo }\end{array}$ & $\begin{array}{c}1,52261^{*} \\
(0,785925)\end{array}$ & $\begin{array}{l}4,1382^{* *} \\
(1,8707)\end{array}$ & $\begin{array}{c}4,3684 \\
(3,2987)\end{array}$ & $\begin{array}{c}1,3044 \\
(1,8900)\end{array}$ & $\begin{array}{c}0,9013 \\
(1,6302)\end{array}$ \\
\hline Razão de & 0,003075 & $-0,5487^{\star \star *}$ & $-0,2793^{*}$ & $-0,4790^{\star \star \star}$ & $-0,0305$ \\
\hline Dependência & $(0,035826)$ & $(0,1314)$ & $(0,1479)$ & $(0,1961)$ & $(0,0202)$ \\
\hline $\begin{array}{c}\text { Preço de } \\
\text { Commodities ex- } \\
\text { Petróleo }\end{array}$ & $\begin{array}{c}1,30004^{*} \\
(0,682531)\end{array}$ & $\begin{array}{l}4,0570^{* *} \\
(1,6116)\end{array}$ & $\begin{array}{c}6,4198 \\
(5,7406)\end{array}$ & $\begin{array}{l}-4,1865 \\
(4,3968)\end{array}$ & $\begin{array}{l}0,7806 \\
(1,405)\end{array}$ \\
\hline $\begin{array}{c}\text { Estabilidade } \\
\text { Política }\end{array}$ & $\begin{array}{l}-0,245524 \\
(0,244858)\end{array}$ & $\begin{array}{r}-0,45215 \\
(0,7364)\end{array}$ & $\begin{array}{l}-0,2656 \\
(0,7511)\end{array}$ & $\begin{array}{l}-0,5384 \\
(0,7472)\end{array}$ & $\begin{array}{l}-0,2498 \\
(0,2475)\end{array}$ \\
\hline Suporte FMI & $\begin{array}{l}-0,211669 \\
(0,466022)\end{array}$ & $\begin{array}{l}0,21838 \\
(0,7633)\end{array}$ & $\begin{array}{l}-0,1944 \\
(0,7953)\end{array}$ & $\begin{array}{c}0,0853 \\
(1,0315)\end{array}$ & $\begin{array}{l}-0,1844 \\
(0,4240)\end{array}$ \\
\hline Regra Fiscal & $\begin{array}{c}-0,825267^{* *} \\
(0,41145)\end{array}$ & $\begin{array}{l}-2,7265^{*} \\
(1,3111)\end{array}$ & $\begin{array}{c}-2,577 \\
(1,3259)\end{array}$ & $\begin{array}{c}0,0853 \\
(1,0315)\end{array}$ & $\begin{array}{l}-0,7717^{* *} \\
(0,3641)\end{array}$ \\
\hline Constante & $\begin{array}{l}-0,30898 \\
(4,69137)\end{array}$ & $\begin{array}{c}-35,476^{* * *} \\
(10,224)\end{array}$ & $\begin{array}{l}-34,321 \\
(22,073)\end{array}$ & $\begin{array}{c}-4,847 \\
(6,4702)\end{array}$ & $\begin{array}{c}1,404 \\
(6,4764)\end{array}$ \\
\hline $\begin{array}{l}\text { Número de } \\
\text { Observações }\end{array}$ & 266 & 266 & 266 & 247 & 266 \\
\hline $\begin{array}{l}\text { Número de } \\
\text { países }\end{array}$ & 19 & 19 & 19 & 19 & 19 \\
\hline $\begin{array}{l}\text { Efeito fixo de } \\
\text { países }\end{array}$ & Não & Sim & Sim & Sim & Sim \\
\hline $\begin{array}{c}\text { Efeito fixo de } \\
\text { tempo }\end{array}$ & Não & Não & Sim & Sim & Sim \\
\hline $\begin{array}{c}R^{2} \\
\mathrm{AR}(1)\end{array}$ & 0,51 & 0,55 & 0,65 & $\begin{array}{c}0,61 \\
0,6229\end{array}$ & 0,64 \\
\hline
\end{tabular}

Fonte: Elaboração própria

Nota: Os valores com $\left(^{*}\right)$ indicam que rejeitamos a hipótese nula a $10 \%$, valores com $\left(^{* *}\right)$ indicam que rejeitamos a hipótese nula a $5 \%$, valores com ${ }^{* * *}$ indicam que rejeitamos a hipótese nula a 1\%. Erro-padrão em (). 
Como é possível observar, para todos os métodos de estimação distintos apresentados há evidências de fadiga fiscal, com os termos quadrático e cúbico sendo estatisticamente significantes em todas as regressões e apresentando os sinais esperados.

Com isso, faremos outro procedimento de robustez com base em parte na metodologia utilizada por Everaert e Jansen (2017). Neste caso, incluiremos a defasagem do resultado primário na estimação. Essa metodologia leva em consideração algum tipo de persistência no resultado primário que pode estar relacionado à dificuldade de se realizar ajustes em gastos e receitas. Entretanto, ao contrário dos autores, optaremos por realizar a estimação por meio da metodologia de Arellano e Bond (1991), que trata o problema de viés causado pela inclusão da variável explicada defasada como variável explicativa de forma eficiente ${ }^{32}$.

${ }^{32}$ Os autores justificam a não utilização da metodologia que trata este viés com o fato de como a dimensão tempo é relativamente grande, então espera-se que o viés seja bem pequeno, como demonstrado por Judson e Owen (1999). Com isso, os autores fazem a estimação por meio do estimador Pooled Mean Group (PMG) que é consistente quando a dimensão tempo tende ao infinito. Como, no nosso caso, a dimensão tempo é pequena, não podemos replicar a mesma metodologia dos autores. 
Tabela 11: Estimação da função de reação fiscal com o resultado primário defasado

\begin{tabular}{|c|c|}
\hline Variáveis & \\
\hline Primário defasado & $\begin{array}{c}0,3876^{\star \star \star} \\
(0,1025)\end{array}$ \\
\hline Dívida defasada & $\begin{array}{l}-0,2640^{*} \\
(0,1406)\end{array}$ \\
\hline Dívida defasada ao quadrado & $\begin{array}{l}0,00507^{*} \\
(0.00283)\end{array}$ \\
\hline Dívida defasada ao cubo & $\begin{array}{c}-0,00003^{*} \\
(0,00002)\end{array}$ \\
\hline Hiato do produto & $\begin{array}{c}0,2498^{* * *} \\
(0,0890)\end{array}$ \\
\hline Hiato dos gastos do governo & $\begin{array}{c}-0,05174^{* *} \\
(0,02413)\end{array}$ \\
\hline Abertura Comercial & $\begin{array}{c}0,0022 \\
(0,06031)\end{array}$ \\
\hline Conta Corrente & $\begin{array}{c}0,4075^{\star \star \star} \\
(0,0994)\end{array}$ \\
\hline Inflação & $\begin{array}{c}0,0699 \\
(00909)\end{array}$ \\
\hline Preço do petróleo & $\begin{array}{l}2,8110^{\star *} \\
(1.3651)\end{array}$ \\
\hline Razão de Dependência & $\begin{array}{c}-0,5238^{\star * *} \\
(0,1182)\end{array}$ \\
\hline Preço de Commodities ex-Petróleo & $\begin{array}{l}4,313^{\star * *} \\
(1,4722)\end{array}$ \\
\hline Estabilidade Política & $\begin{array}{l}-0,3141 \\
(0,9425)\end{array}$ \\
\hline Suporte Financeiro do FMI & $\begin{array}{c}0,3391 \\
(0,4747)\end{array}$ \\
\hline Regra Fiscal & $\begin{array}{l}-0,8819 \\
(0,9090)\end{array}$ \\
\hline Constante & $\begin{array}{c}-40,270^{* * *} \\
(10,016)\end{array}$ \\
\hline Coeficiente AR(1) & 0,5439351 \\
\hline Número de Observações & 252 \\
\hline$R^{2}$ & 0,4373 \\
\hline Teste $\mathrm{F}$ & 11,72 \\
\hline
\end{tabular}

Fonte: Elaboração própria

Nota: Os valores com $\left(^{\star}\right)$ indicam que rejeitamos a hipótese nula a $10 \%$, valores com $\left(^{\star *}\right)$ indicam que rejeitamos a hipótese nula a $5 \%$, valores com $\left(^{\star * \star}\right)$ indicam que rejeitamos a hipótese nula a 1\%. Erro-padrão em ().

Assim como nos testes de robustez realizados anteriormente, a hipótese de fadiga fiscal ainda se mantém. Além disso, observamos que o resultado primário defasado é estatisticamente significante, indicando que há persistência em seus resultados primários. Isso é um indicativo da dificuldade em serem feitos 
ajustes que levem a alterações significativas no resultado primário em um curto espaço de tempo.

Outra questão relevante que surge em estimações em painel com efeito fixo é sobre a homogeneidade do parâmetro de inclinação. No nosso caso, este problema é ainda maior, pois assumimos que a função cúbica é válida para todos os níveis de endividamento, sendo que apenas uma porção dos países da nossa amostra alcançam níveis de endividamento do patamar da fadiga fiscal. Portanto, pressupomos que todos os países terão performance semelhante, em termos de fadiga fiscal, aos países com endividamento elevado.

Amparamos este pressuposto com base no fato de termos tentado criar uma amostra mais homogênea possível, unindo países emergentes que já possuem algumas características semelhantes para se enquadrarem neste grupo, além de reduzirmos nossa amostra com base nos resultados do diferencial entre taxa de juros e crescimento econômico. Além disso, há uma limitação em termos do tamanho do resultado primário possível de ser alcançado pelos países, dado que não é possível que este seja superior ao PIB. Portanto, deve haver, em algum ponto, uma redução na reação fiscal.

Entretanto, estas são apenas formas teóricas de embasarmos nossa hipótese, mas que não corroboram, empiricamente, a homogeneidade. Como dito anteriormente, como somente alguns países alcançam níveis elevados de endividamento, não conseguimos testar por meios convencionais a hipótese de homogeneidade. Portanto, assim como Ghosh et al. (2013), iremos separar o endividamento em dois grupos: baixo-médio (10\% a $70 \%$ do PIB) e médio-alto (maior que $70 \%$ do PIB).

Para o grupo de baixo-médio, iremos verificar se os países possuem resposta similar no resultado primário a variações na dívida defasada. Para isso, faremos a seguinte regressão:

$$
p b_{i, t}=\alpha_{i}+\beta_{1} d_{i, t-1}+\beta_{2} d_{i, t-1} * d u m m y_{i}+\gamma Z_{i, t}+\varepsilon_{i, t}
$$

Em que a única diferença em relação a equação (7) é que adicionamos uma variável dummy para cada país e somente utilizamos o endividamento defasado no nível. Com isso, como para níveis baixos-médios de endividamento não há fadiga fiscal, observamos apenas o endividamento no nível e esperamos que haja uma resposta positiva do resultado primário a aumentos no endividamento, o que segundo a teoria de Bohn (1998) significaria que os países 
aumentam seus resultados primários quando há um aumento no seu nível de endividamento. 
Tabela 12: Estimação da Função de Reação Fiscal para endividamento baixo-médio

\begin{tabular}{|c|c|c|c|c|c|c|c|c|c|c|c|}
\hline$d_{i, t-1}$ & $\begin{array}{l}0,1156^{\star *} \\
(0,0521)\end{array}$ & $\begin{array}{l}0,0860^{*} \\
(0,0501)\end{array}$ & $\begin{array}{l}0,0934^{*} \\
(0,0544)\end{array}$ & $\begin{array}{l}0,1212^{\star \star} \\
(0,0532)\end{array}$ & $\begin{array}{l}0,1041^{\star \star} \\
(0,0523)\end{array}$ & $\begin{array}{l}0,1326^{\star *} \\
(0,0569)\end{array}$ & $\begin{array}{l}0,1336^{\star \star} \\
(0,0550)\end{array}$ & $\begin{array}{l}0,0995^{\star} \\
(0,0526)\end{array}$ & $\begin{array}{l}0,1160 \text { ** } \\
(0,0530)\end{array}$ & $\begin{array}{l}0,1099^{\star *} \\
(0,0518)\end{array}$ & $\begin{array}{l}0,1182^{*} \\
(0,0531)\end{array}$ \\
\hline$d_{i, t-1} * d_{\text {Argelia }}$ & & $\begin{array}{l}0,736^{\star * *} \\
(0,2834)\end{array}$ & & & & & & & & & \\
\hline$d_{i, t-1} * d_{\text {Azerbaijão }}$ & & & $\begin{array}{c}0,2314 \\
(0,1506)\end{array}$ & & & & & & & & \\
\hline$d_{i, t-1} * d_{\text {Brasil }}$ & & & & $\begin{array}{l}-0,1545 \\
(0,2774)\end{array}$ & & & & & & & \\
\hline$d_{i, t-1} * d_{\text {Colômbia }}$ & & & & & $\begin{array}{l}0,5035^{*} \\
(0,2593)\end{array}$ & & & & & & \\
\hline$d_{i, t-1} * d_{\text {Croácia }}$ & & & & & & $\begin{array}{l}-0,0968 \\
(0,1293)\end{array}$ & & & & & \\
\hline $\begin{array}{l}d_{i, t-1} \\
* d_{\text {Dominicana }}\end{array}$ & & & & & & & $\begin{array}{l}-0,1725 \\
(0,1673)\end{array}$ & & & & \\
\hline$d_{i, t-1} * d_{\text {Equador }}$ & & & & & & & & $\begin{array}{l}0,5010^{*} \\
(0,2671)\end{array}$ & & & \\
\hline$d_{i, t-1} * d_{\text {Hungria }}$ & & & & & & & & & $\begin{array}{l}-0,0123 \\
(0,3151)\end{array}$ & & \\
\hline$d_{i, t-1} * d_{M \text { éxico }}$ & & & & & & & & & & $\begin{array}{l}0,6788^{* *} \\
(0,3211)\end{array}$ & \\
\hline$d_{i, t-1} * d_{\text {Marrocos }}$ & & & & & & & & & & & $\begin{array}{l}-0,0690 \\
(0,2561)\end{array}$ \\
\hline Observações & 247 & 247 & 247 & 247 & 247 & 247 & 247 & 247 & 247 & 247 & 247 \\
\hline$R^{2}$ & 0,29 & 0,30 & 0,30 & 0,29 & 0,30 & 0,29 & 0,29 & 0,30 & 0,29 & 0,30 & 0,29 \\
\hline Coeficiente AR(1) & 0,705 & 0,640 & 0,714 & 0,706 & 0,707 & 0,704 & 0,707 & 0,705 & 0,705 & 0,705 & 0,705 \\
\hline
\end{tabular}

Nota: Os valores com $\left({ }^{*}\right)$ indicam que rejeitamos a hipótese nula a $10 \%$, valores com $\left(^{* *}\right)$ indicam que rejeitamos a hipótese nula a $5 \%$, valores com (***) indicam que rejeitamos a hipótese nula a $1 \%$. Erro-padrão em (). 


\begin{tabular}{|c|c|c|c|c|c|c|c|c|c|}
\hline$d_{i, t-1}$ & $\begin{array}{l}0,1207^{\star *} \\
(0,0528)\end{array}$ & $\begin{array}{l}0,1184^{* *} \\
(0,0528)\end{array}$ & $\begin{array}{l}0,1249^{* *} \\
(0,0530)\end{array}$ & $\begin{array}{l}0,1173^{\star *} \\
(0,0528)\end{array}$ & $\begin{array}{l}0,1182^{* *} \\
(0,0538)\end{array}$ & $\begin{array}{l}0,1153^{\star *} \\
(0,0536)\end{array}$ & $\begin{array}{l}0,1159^{\star *} \\
(0,0529)\end{array}$ & $\begin{array}{l}0,1343^{*} \\
(0,0530)\end{array}$ & $\begin{array}{c}0,1240 * \\
(0,0545)\end{array}$ \\
\hline$d_{i, t-1} * d_{O m a ̃}$ & $\begin{array}{c}-0,1789 \\
(0,2715)\end{array}$ & & & & & & & & \\
\hline$d_{i, t-1} * d_{P e r u}$ & & $\begin{array}{c}-0,0954 \\
(0,2564)\end{array}$ & & & & & & & \\
\hline$d_{i, t-1} * d_{\text {Filipinas }}$ & & & $\begin{array}{l}-0,1936 \\
(0,1976)\end{array}$ & & & & & & \\
\hline$d_{i, t-1} * d_{\text {Polônia }}$ & & & & $\begin{array}{c}-0,085 \\
(0,3708)\end{array}$ & & & & & \\
\hline$d_{i, t-1} * d_{\text {Romênia }}$ & & & & & $\begin{array}{l}-0,0355 \\
(0,1755)\end{array}$ & & & & \\
\hline$d_{i, t-1} * d_{\hat{A} \text { frica }}$ & & & & & & $\begin{array}{c}0,0061 \\
(0,2501)\end{array}$ & & & \\
\hline$d_{i, t-1} * d_{\text {Turquia }}$ & & & & & & & $\begin{array}{l}-0,0151 \\
(0,2909)\end{array}$ & & \\
\hline$d_{i, t-1} * d_{\text {Emirados }}$ & & & & & & & & $\begin{array}{c}-0,3983 \\
(0,2476)\end{array}$ & \\
\hline$d_{i, t-1} * d_{\text {Uruguai }}$ & & & & & & & & & $\begin{array}{l}-0,0907 \\
(0,1694)\end{array}$ \\
\hline Observações & 247 & 247 & 247 & 247 & 247 & 247 & 247 & 247 & 247 \\
\hline$R^{2}$ & 0,29 & 0,29 & 0,29 & 0,29 & 0,29 & 0,29 & 0,29 & 0,30 & 0,29 \\
\hline Coeficiente $\mathrm{AR}(1)$ & 0,700 & 0,704 & 0,701 & 0,705 & 0,705 & 0,705 & 0,704 & 0,689 & 0,706 \\
\hline
\end{tabular}

Fonte: Elaboração própria

Nota: Os valores com $\left(^{\star}\right)$ indicam que rejeitamos a hipótese nula a $10 \%$, valores com $\left(^{\star *}\right)$ indicam que rejeitamos a hipótese nula a $5 \%$, valores com $\left({ }^{* * \star}\right)$ indicam que rejeitamos a hipótese nula a $1 \%$. Erro-padrão em (). 
Os resultados obtidos indicam que para todos os países não é possível rejeitar a hipótese de que há uma resposta linear positiva do resultado primário a variações no endividamento defasado; sendo que, para alguns países, essa reposta é estatisticamente maior que a média. Com isso, podemos argumentar que como temos países que possuem endividamento baixo-médio em um período e médio-alto em outro e países que só possuem baixo-médio e ambos têm resposta semelhante, então podemos argumentar que estes se comportarão de forma similar para níveis médio-alto.

Outro ponto importante é verificar se todos os países de endividamento médio-alto apresentam fadiga fiscal. Se esta hipótese for válida, podemos esperar que esse comportamento seja válido para todos os outros da nossa amostra. Apenas cinco países possuem nível de endividamento superior a 70\% do $\mathrm{PIB}^{33} \mathrm{em}$ algum período. Como todos estes países já estiveram, também, em endividamentos de nível baixo-médio em algum período, isso nos possibilita verificar se a hipótese de fadiga fiscal é individualmente válida.

Para isso, estimaremos a seguinte equação:

$$
\begin{aligned}
& p b_{i, t}=\alpha_{i}+\beta_{1} d_{i, t-1}+\beta_{2} d_{i, t-1}^{2}+\beta_{3} d_{i, t-1}^{3}+\beta_{4} d_{i, t-1} * d u m m y_{i}+\beta_{5} d_{i, t-1}^{2} * \\
& \text { dummy }_{i}+\beta_{6} d_{i, t-1}^{3} * d u m m y_{i}+\gamma Z_{i, t}+\varepsilon_{i, t}
\end{aligned}
$$

Em que adicionamos uma varável dummy para cada país e testamos a significância conjunta dos coeficientes $\beta_{4}, \beta_{5}$ e $\beta_{6}$.

\footnotetext{
${ }^{33}$ Os países selecionados são: Brasil, Croácia, Hungria, Filipinas e Uruguai.
} 
Tabela 13: Estimação da Função de Reação Fiscal para endividamento médio-alto

\begin{tabular}{|c|c|c|c|c|}
\hline$d_{i, t-1}$ & $\begin{array}{c}-1,6389^{* * *} \\
(0,5659)\end{array}$ & $\begin{array}{c}-1,6471^{* \star *} \\
(06103)\end{array}$ & $-2,4934^{* * *}$ & $-1,3273^{* *}$ \\
\hline$d_{i+T_{1}}^{2}$ & $0,0215^{\star \star *}$ & $0,02207^{* *}$ & $\begin{array}{l}(0,0312) \\
0,0312^{* *}\end{array}$ & $\begin{array}{l}(0,5873) \\
0.0178^{* *}\end{array}$ \\
\hline$a_{i, t-1}$ & $(0,0079)$ & $(0,00852)$ & $(0,0118)$ & $(0,0080)$ \\
\hline$d_{i, t-1}^{3}$ & $\begin{array}{c}-0,00009^{* *} \\
(0,00004)\end{array}$ & $\begin{array}{c}-0,00009^{*} \\
(0,00004)\end{array}$ & $\begin{array}{c}-0,00012^{\star *} \\
(0,00005)\end{array}$ & $\begin{array}{l}-0,00007^{*} \\
(0,00004)\end{array}$ \\
\hline$d_{i, t-1} * d_{\text {Brasil }}$ & & $\begin{array}{l}-40,997 \\
(66,407)\end{array}$ & & \\
\hline$d_{i, t-1}^{2} * d_{B r a s i l}$ & & $\begin{array}{l}0,6506 \\
(1,007)\end{array}$ & & \\
\hline$d_{i, t-1}^{3} * d_{\text {Brasil }}$ & & $\begin{array}{l}-0,0034 \\
(0,0051)\end{array}$ & & \\
\hline$d_{i, t-1} * d_{C r o a ́ c i a}$ & & & $\begin{array}{c}1,0720 \\
(2,2972)\end{array}$ & \\
\hline$d_{i, t-1}^{2} * d_{\text {Croácia }}$ & & & $\begin{array}{l}-0,0142 \\
(0,0369)\end{array}$ & \\
\hline$d_{i, t-1}^{3} * d_{\text {Croácia }}$ & & & $\begin{array}{l}-0,00007 \\
(0,0002)\end{array}$ & \\
\hline$d_{i, t-1} * d_{\text {Hungria }}$ & & & & $\begin{array}{c}35,914 \\
(43,294)\end{array}$ \\
\hline$d_{i, t-1}^{2} * d_{\text {Hungria }}$ & & & & $\begin{array}{l}-0,4796 \\
(0,6130)\end{array}$ \\
\hline$d_{i, t-1}^{3} * d_{\text {Hungria }}$ & & & & $\begin{array}{c}0,0021 \\
(0,0029)\end{array}$ \\
\hline Observações & 65 & 65 & 65 & 65 \\
\hline$R^{2}$ & 0,54 & 0,56 & 0,61 & 0,67 \\
\hline Coeficiente AR(1) & 0,299 & 0,299 & 0,220 & 0,233 \\
\hline Teste Conjunto ( $p$-valor) & & 0,59 & 0,32 & 0,53 \\
\hline
\end{tabular}




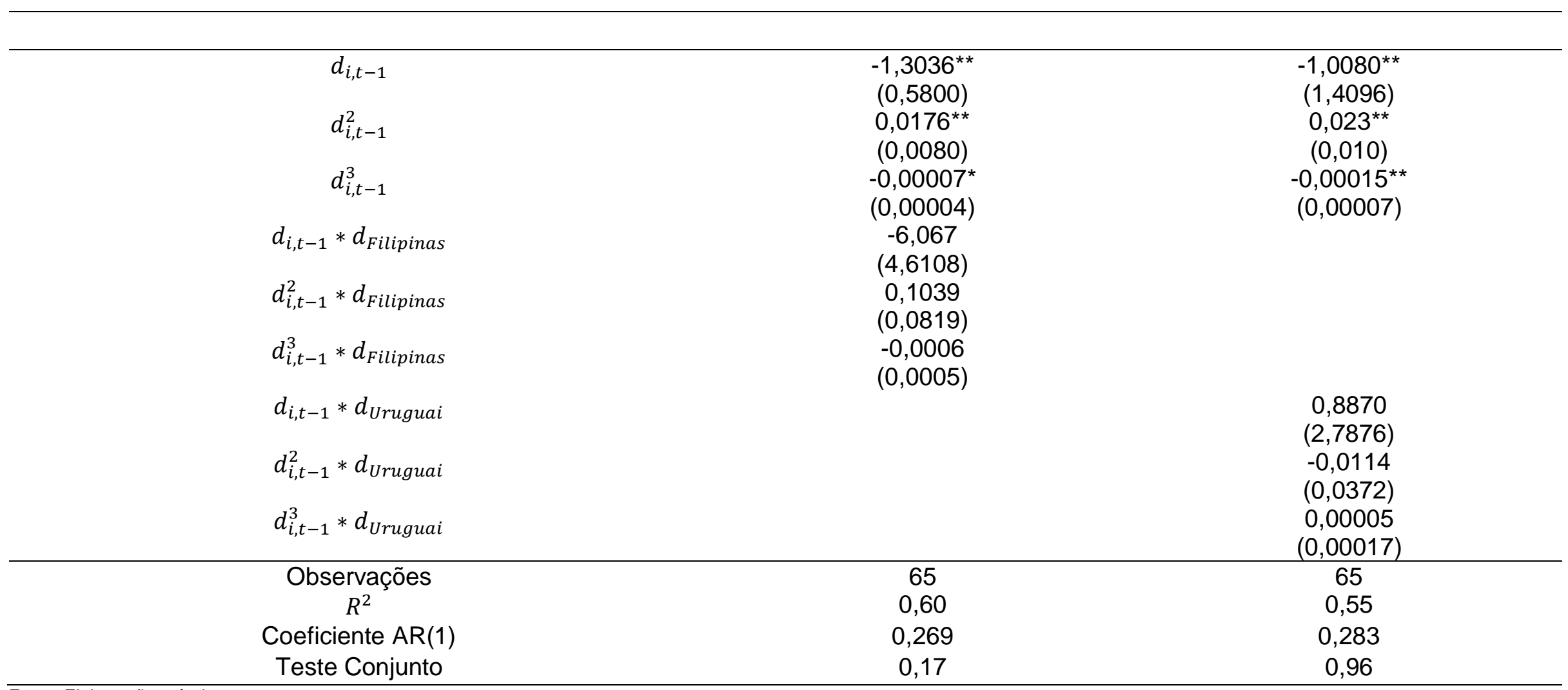

Fonte: Elaboração própria

Nota: Os valores com $\left(^{\star}\right)$ indicam que rejeitamos a hipótese nula a $10 \%$, valores com $\left(^{* *}\right)$ indicam que rejeitamos a hipótese nula a $5 \%$, valores com $\left(^{\star * \star}\right)$ indicam que rejeitamos a hipótese nula a $1 \%$. Erro-padrão em (). 
Os resultados apresentados reforçam a existência da fadiga fiscal para países com elevado endividamento. Mais importante ainda, não rejeitamos a hipótese nula de homogeneidade em todos os países analisados, demonstrando que essa hipótese é satisfeita individualmente.

Por fim, podem surgir críticas quanto a possíveis problemas de causalidade reversa existente na relação entre resultado primário e endividamento, mesmo quando utilizamos o endividamento defasado. Para lidarmos como este problema, decidimos utilizar a metodologia de variáveis instrumentais estimando por meio do Método de Momentos Generalizados (GMM) em dois estágios robusto para heterocedasticidade. Como variável instrumental, optamos pelo uso da média até a quinta defasagem do endividamento público, seguindo o método utilizado por Kumar e Woo (2010) para o efeito do endividamento sobre o crescimento econômico. Esperamos que este instrumento apresente elevada correlação com a variável instrumentada; entretanto, como há uma elevada persistência em variáveis de estoque de dívida, ele pode não ser o instrumento mais adequado. Porém, na ausência de um instrumento melhor e para fins de robustez nos nossos resultados, ele se mostra adequado ${ }^{34}$.

\footnotetext{
${ }^{34}$ Tentamos utilizar como instrumento o definido por Checherita-Westphal e Rotter (2012) que utiliza a média do endividamento dos outros países na amostra para o respectivo ano como instrumento para o país que tem o seu endividamento sendo instrumentalizado. Entretanto, as hipóteses de instrumento fraco e subidentificação não foram rejeitadas, logo este instrumento não se mostrou adequado para este modelo.
} 
Tabela 14: Estimação da função de reação fiscal por variáveis instrumentais via GMM

\begin{tabular}{|c|c|}
\hline Variáveis & Estimação II \\
\hline Dívida defasada & $\begin{array}{c}-0,287993^{\star} \\
(0,1704882)\end{array}$ \\
\hline Dívida defasada ao quadrado & $\begin{array}{l}0,0073023^{\star} \\
(0,0037793)\end{array}$ \\
\hline Dívida defasada ao cubo & $\begin{array}{l}-0,0000465^{\star} \\
(0,0000248)\end{array}$ \\
\hline Hiato do produto & $\begin{array}{c}0,2410666^{* * *} \\
(0,0777479)\end{array}$ \\
\hline Hiato dos gastos do governo & $\begin{array}{c}0,0107999 \\
(0,0317892)\end{array}$ \\
\hline Abertura Comercial & $\begin{array}{c}-0,0337877 \\
(0,0277824)\end{array}$ \\
\hline Conta Corrente & $\begin{array}{c}0,3376827^{* * *} \\
(0,0785034)\end{array}$ \\
\hline Inflação & $\begin{array}{c}0,0440182 \\
(0,0596756)\end{array}$ \\
\hline Preço do petróleo & $\begin{array}{c}4,864277^{\star \star \star} \\
(1,406214)\end{array}$ \\
\hline Razão de Dependência & $\begin{array}{c}-0,5279656^{\star * *} \\
(0,0958036)\end{array}$ \\
\hline Preço de Commodities ex-Petróleo & $\begin{array}{l}4,010603^{* * *} \\
(0,9652685)\end{array}$ \\
\hline Estabilidade Política & $\begin{array}{c}-0,202044 \\
(0,4963542)\end{array}$ \\
\hline Suporte Financeiro do FMI & $\begin{array}{c}-0,2795861 \\
(0,5475307)\end{array}$ \\
\hline Regra Fiscal & $\begin{array}{l}-2,902711^{\star * *} \\
(0,8924039)\end{array}$ \\
\hline Número de Observações & 257 \\
\hline$R^{2}$ Centrado & 0,5573 \\
\hline Teste F & 13,64 \\
\hline P-valor do Kleibergen-Paap LM estat. & 0,0004 \\
\hline Kleibergen-Paap Wald F estat. & 12,68 \\
\hline
\end{tabular}

Fonte: Elaboração própria

Nota: Os valores com $\left({ }^{*}\right)$ indicam que rejeitamos a hipótese nula a 10\%, valores com $\left(^{* *}\right)$ indicam que rejeitamos a hipótese nula a $5 \%$, valores com ${ }^{* * *}$ indicam que rejeitamos a hipótese nula a 1\%. Erro-padrão em ().

Como é possível verificar acima, levando em consideração um possível problema de causalidade reversa e utilizando variáveis instrumentais para lidar com ele, a hipótese de fadiga fiscal para países emergentes se mantem com os coeficientes de endividamento sendo estatisticamente significantes e com os mesmos sinais apresentados anteriormente. Além disso, como era esperado, os instrumentos utilizados se mostraram relevantes tanto no teste de subidentificação quanto no teste de instrumentos fracos. 
Com isso, nesta subseção demonstramos que nosso resultado de fadiga fiscal é robusto para diferentes metodologias de estimação e para uma especificação diferente desta função. Além disso, nossa hipótese de homogeneidade é comprovada. Quando o nível de endividamento é baixo, os países possuem uma resposta homogênea (positiva) do resultado primário a variações no endividamento. Para níveis altos de endividamento, a fadiga fiscal é verificada em todos os países que estão neste grupo. Por fim, mesmo admitindo um potencial problema de causalidade reversa, a regressão com variáveis instrumentais corroborou nosso resultado de fadiga fiscal.

\subsubsection{Intervalo de Confiança da redução na resposta marginal e do ponto de reversão}

Além dos métodos que envolvem as metodologias de estimação e a homogeneidade, faremos, também, o cálculo do intervalo de confiança para os pontos de redução na resposta marginal e de reversão que, como encontrado na nossa estimação de reação fiscal, se encontram em torno de $70 \%$ e $110 \%$, respectivamente.

Como nosso ponto de redução na resposta marginal e de reversão são formados pela combinação não linear dos parâmetros de três coeficientes endividamento, endividamento ao quadrado e endividamento ao cubo - a distribuição normal com intervalo de confiança a 95\% estimada para cada coeficiente não pode ser utilizada para obter o intervalo de confiança para estes pontos. Para lidarmos com este problema faremos uso do método Delta, que basicamente expande uma função de variáveis aleatórias sobre a sua média utilizando uma aproximação de Taylor e, então, obtém o resultado da variância. Como o método Delta assume que o coeficiente no modelo possui distribuição normal, ele acaba sendo influenciado pelo tamanho da amostra, como apresentado em Hole (2007). Portanto, como temos um número razoável de amostras (247 observações), esperamos que o método Delta seja adequado para o cálculo dos intervalos.

Desta forma, por meio desta metodologia, encontramos que com $95 \%$ de confiança, o ponto de redução na resposta marginal esteja entre 53,1 e 81,8\% do PIB, enquanto que para o ponto de reversão da função de reação fiscal o 
intervalo de confiança está entre $81,6 \%$ e $132,5 \%$ do PIB. É importante notar que, mesmo para o limite superior do intervalo de confiança, estes pontos são inferiores aos obtidos para os países desenvolvidos, corroborando este resultado.

\subsubsection{Limite de endividamento}

Tendo estimado a função de reação fiscal, para obtermos o limite de endividamento precisamos do resultado do diferencial entre taxa de juros e crescimento econômico. Abaixo, apresentaremos os resultados para as duas metodologias do cálculo do diferencial entre taxa de juros e crescimento econômico.

Partindo da primeira metodologia, apresentamos abaixo a média para os últimos 11 anos (2006 a 2016) do diferencial entre taxa de juros e crescimento econômico para nossa amostra.

Tabela 15: Diferencial entre taxa de juros e crescimento econômico (em $\%)$ pelo método da média

\begin{tabular}{cc}
\hline País & $\begin{array}{c}\text { Diferencial entre taxa de juros e } \\
\text { crescimento econômico }\end{array}$ \\
\hline África do Sul & $-0,697$ \\
Argélia & $-6,498$ \\
Azerbaijão & $-16,01$ \\
Brasil & 5,017 \\
Colômbia & $-1,227$ \\
Croácia & 1,334 \\
República Dominicana & $-0,116$ \\
Emirados Árabes Unidos & $-6,196$ \\
Equador & $-3,203$ \\
Filipinas & $-2,004$ \\
Hungria & 1,211 \\
México & 1,293 \\
Marrocos & $-0,910$ \\
Omã & $-5,050$ \\
Peru & 5,627 \\
Polônia & $-0,873$ \\
Romênia & $-2,563$ \\
Turquia & $-2,963$ \\
Uruguai & $-2,340$ \\
\hline
\end{tabular}


Apesar de termos excluído países em que o diferencial de juros é negativo, como apresentado anteriormente, mantivemos aqueles em que esse diferencial não seja muito negativo, pois ele pode rapidamente se tornar positivo. Por isso, mantivemos na nossa amostra países em que o diferencial é superior a $-3 \%{ }^{35}$.

Outro ponto importante é que este diferencial muda muito para alguns países ao longo dos anos. Com isso, mantivemos os países que nos últimos 3 anos (2014 a 2016) a média foi positiva, no caso Argélia, Azerbaijão, Emirados Árabes Unidos, Equador e Omã. Por fim, mantivemos na amostra os países que a média do diferencial nos últimos 11 anos foi positiva.

Antes de apresentarmos os resultados de limite de endividamento para os países da nossa amostra, exemplificamos, na prática, a função de reação e os diferenciais de juros determinista e estocástico para o caso brasileiro.

Figura 8: Função de reação fiscal e diferenciais de juros para o caso brasileiro

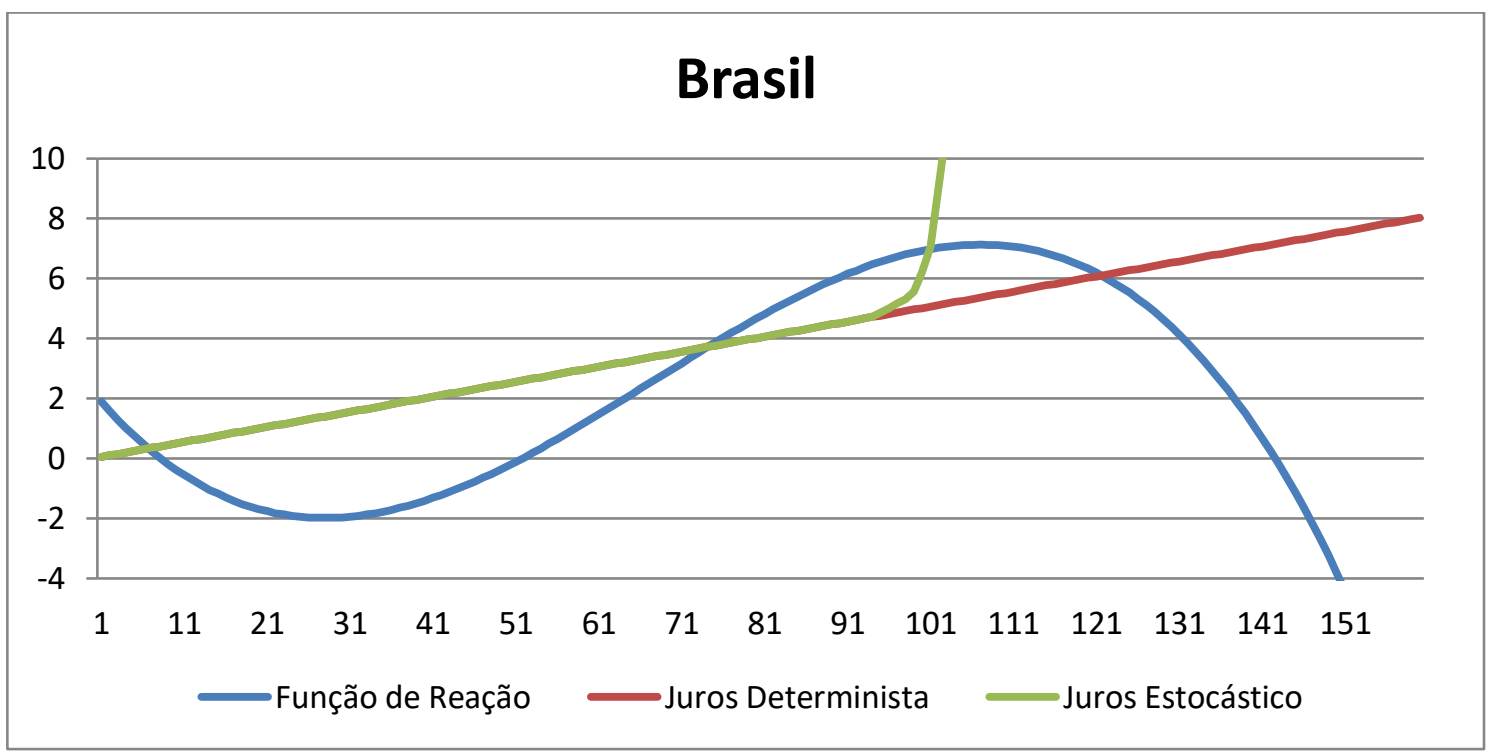

Fonte: FMI. Elaboração própria

35 Analisamos, também, o desvio padrão destes países que foram adicionados e todos apresentaram desvio padrão relativamente elevado, o que torna possível apresentarem juros positivos nos próximos anos. 
Tendo estimado a função de reação fiscal e calculado o diferencial entre taxa de juros e crescimento econômico, obtivemos o limite de endividamento e o espaço fiscal que cada país possui pelo conceito determinista.

Tabela 16: Espaço Fiscal e Limite de Endividamento para o caso determinista para o diferencial pela média (em \% do PIB)

\begin{tabular}{|c|c|c|c|c|}
\hline País & Dívida Atuala $^{\mathrm{a}}$ & Espaço Fiscal & $\begin{array}{l}\text { Limite de } \\
\text { Endividamento }\end{array}$ & $\begin{array}{c}\text { Intervalo de } \\
\text { Endividamento }\end{array}$ \\
\hline África do Sul & 51,6 & 103,1 & 154,7 & $(152,8 ; 157,1)$ \\
\hline Argélia & 20,4 & 151,8 & 172,2 & $(164,4 ; 184,0)$ \\
\hline Azerbaijão & 50,7 & 133,2 & 183,9 & $(158,8 ; 204,6)$ \\
\hline Brasil & 78,4 & 43,1 & 121,5 & $(103,1 ; 136,3)$ \\
\hline Colômbia & 49,8 & 101,3 & 151,1 & $(146,8 ; 153,2)$ \\
\hline Croácia & 82,3 & 61,5 & 143,8 & $(135,5 ; 152,6)$ \\
\hline $\begin{array}{l}\text { República } \\
\text { Dominicana }\end{array}$ & 34,6 & 126,3 & 160,9 & $(155,2 ; 164,2)$ \\
\hline $\begin{array}{l}\text { Emirados } \\
\text { Árabes Unidos }\end{array}$ & 20,2 & 119,3 & 139,5 & $(-; 170,3)$ \\
\hline Equador & 43,2 & 125,5 & 168,7 & $(160,6 ; 173,7)$ \\
\hline Filipinas & 39,0 & 129,9 & 168,9 & $(168,2 ; 172,8)$ \\
\hline Hungria & 76,0 & 67,4 & 143,4 & $(142,0 ; 147,9)$ \\
\hline México & 56,8 & 99,7 & 156,5 & $(153,3 ; 161,1)$ \\
\hline Marrocos & 64,9 & 91,0 & 155,9 & $(151,1 ; 158,9)$ \\
\hline Omã & 32,5 & 129,7 & 162,2 & $(133,9 ; 178,0)$ \\
\hline Peru & 24,5 & 115,5 & 140,0 & $(120,5 ; 155,7)$ \\
\hline Polônia & 54,2 & 82,3 & 136,5 & $(130,4 ; 142,1)$ \\
\hline Romênia & 38,8 & 109,2 & 148,0 & $(140,3 ; 150,2)$ \\
\hline Turquia & 28,3 & 129,5 & 157,8 & $(155,2 ; 164,9)$ \\
\hline Uruguai & 61,6 & 100,5 & 162,1 & $(158,9 ; 165,1)$ \\
\hline Média & 47,8 & 106,3 & 154,1 & $(146,2 ; 162,8)$ \\
\hline Mediana & 49,8 & 109,2 & 155,9 & $(152,0 ; 161,1)$ \\
\hline
\end{tabular}

Primeiramente, percebemos que o nível atual de endividamento varia bastante entre os países, mas o nível médio é próximo de $50 \%$ do PIB. Já o limite médio e mediano de endividamento para este grupo de países é de 154,1\% e $155,9 \%$ do PIB, respectivamente. Assim, como era esperado, estes valores são significativamente inferiores aos limites médios e medianos obtidos por Ghosh et al. (2013) para países desenvolvidos de $191,6 \%$ e $195,7 \%$ do PIB, respectivamente. 
Analisando individualmente, o Brasil é o país com o menor limite de endividamento e espaço fiscal entre todos os analisados, apesar de não ser aquele que possui o maior valor atual. Ao lado do Brasil, Hungria e Croácia são os países com menor espaço fiscal entre todos. É importante notar que estes são países em que o diferencial entre taxa de juros e crescimento econômico é positivo, demonstrando como esta variável é importante para a obtenção do limite e espaço fiscal.

Na parte do intervalo de endividamento, calculamos o $25^{\circ}$ e $75^{\circ}$ percentil do diferencial entre taxa de juros e crescimento econômico para os últimos 11 anos (2006 a 2016). Pelos resultados acima é possível observar que, principalmente para o caso do Brasil dentre os três países destacados acima, níveis mais elevados de diferencial fazem com que o limite de endividamento se reduza consideravelmente, como o limite para o 75ำ percentil do diferencial entre juros e crescimento que leva a um limite de endividamento de $103,1 \%$ do PIB.

Entretanto, para este conceito, é importante ponderar que apesar destes países estarem na pior situação fiscal entre os analisados, ainda há uma diferença significativa entre seu nível atual e o máximo e, caso ao longo dos próximos anos sejam realizados ajustes fiscais e reformas, deve haver uma melhora na função de reação fiscal e no diferencial, aumentando os níveis atualmente observados.

Após termos apresentado o conceito determinista para o limite de endividamento, abaixo podemos observar os resultados para conceito estocástico que, na nossa visão, se aproxima mais da realidade. 
Tabela 17: Espaço Fiscal e Limite de Endividamento para o caso estocástico para o diferencial pela média (em \% do PIB)

\begin{tabular}{|c|c|c|c|c|}
\hline País & $\begin{array}{l}\text { Dívida } \\
\text { Atual }^{\mathrm{a}}\end{array}$ & $\begin{array}{c}\text { Espaço } \\
\text { Fiscal }\end{array}$ & $\begin{array}{c}\text { Limite de } \\
\text { Endividamento }\end{array}$ & $\begin{array}{c}\text { Intervalo de } \\
\text { Endividamento }\end{array}$ \\
\hline África do Sul & 51,6 & 75,3 & 126,9 & $(124,9 ; 128,9)$ \\
\hline Argélia & 20,4 & 114,8 & 135,2 & $(128,8 ; 146,0)$ \\
\hline Azerbaiijão & 50,7 & 91,0 & 141,7 & $(112,7 ; 159,7)$ \\
\hline Brasil & 78,4 & 22,1 & 100,5 & $(-; 123,9)$ \\
\hline Colômbia & 49,8 & 65,6 & 115,4 & $(108,5 ; 118,0)$ \\
\hline Croácia & 82,3 & 27,7 & 110,0 & $(93,4 ; 121,1)$ \\
\hline $\begin{array}{c}\text { República } \\
\text { Dominicana }\end{array}$ & 34,6 & 104,5 & 139,1 & $(135,2 ; 141,5)$ \\
\hline $\begin{array}{l}\text { Emirados } \\
\text { Árabes } \\
\text { Unidos }\end{array}$ & 20,2 & - & - & $(-;-)$ \\
\hline Equador & 43,2 & 102,0 & 145,2 & $(139,6 ; 148,8)$ \\
\hline Filipinas & 39,0 & 114,5 & 153,5 & $(149,0 ; 151,2)$ \\
\hline Hungria & 76,0 & 47,9 & 123,9 & $(118,2 ; 139,4)$ \\
\hline México & 56,8 & 77,3 & 134,1 & $(131,8 ; 137,6)$ \\
\hline Marrocos & 64,9 & 63,2 & 128,1 & $(123,9 ; 130,0)$ \\
\hline Omã & 32,5 & 94,5 & 127,0 & $(-; 142,1)$ \\
\hline Peru & 24,5 & 106,7 & 131,2 & $(120,0 ; 141,0)$ \\
\hline Polônia & 54,2 & 78,2 & 132,4 & $(128,8 ; 135,7)$ \\
\hline Romênia & 38,8 & 78,2 & 117,0 & $(99,8 ; 119,9)$ \\
\hline Turquia & 28,3 & 98,9 & 127,2 & $(124,6 ; 133,7)$ \\
\hline Uruguai & 61,6 & 61,8 & 123,4 & $(115,8 ; 130,5)$ \\
\hline Média & 47,8 & 79,1 & 128,4 & $(122,2 ; 136,1)$ \\
\hline Mediana & 49,8 & 78,2 & 127,7 & $(124,3 ; 136,7)$ \\
\hline
\end{tabular}

Assim como era esperado, no caso estocástico os limites são significativamente inferiores ao caso determinista, o que faz com que o espaço fiscal também o seja.

Analisando individualmente, o Brasil é o país com o menor limite e espaço fiscal, estando próximo do nível máximo. Além dele, a Croácia possui espaço fiscal baixo, inferior a 30\%. Para o restante dos países, apesar da redução do limite o do espaço fiscal, os baixos níveis de endividamento ainda mantem suas situações confortáveis.

\footnotetext{
${ }^{36}$ Não foi possível obter o limite de endividamento para os Emirados Árabes Unidos.
} 
Logo, ao contrário do observamos no caso determinista, os países em pior situação fiscal possuem pequeno espaço fiscal, o que torna urgente alterações em sua política fiscal que propiciem uma redução no seu nível de endividamento nos próximos anos. Além disso, assim como no caso determinista, temos que os intervalos do limite de endividamento mostram que para os países que já possuíam espaço fiscal reduzido, situações piores de diferencial entre juros e crescimento econômico, tornam ajustes que levem a reduções no nível de endividamento ainda mais urgentes ${ }^{37}$, enquanto situações melhores de diferencial, ainda assim, levam a um espaço fiscal preocupante para alguns países.

Posteriormente, apresentamos abaixo os resultados para o diferencial entre taxa de juros e crescimento econômico utilizando os resultados obtidos para a estimação da taxa de juros estrutural e do produto potencial para o ano de 2016.

${ }^{37}$ É importante notar que para o caso do Brasil não foi possível obter o limite de endividamento para o diferencial no $75^{\circ}$ percentil, pois a reta do diferencial fica acima da função de reação fiscal. 
Tabela 18: Diferencial entre taxa de juros e crescimento econômico (em $\%)$ pelo método do juros estrutural e do crescimento potencial

\begin{tabular}{cc}
\hline País & $\begin{array}{c}\text { Diferencial entre taxa de juros e } \\
\text { crescimento econômico }\end{array}$ \\
\hline África do Sul & $-0,754$ \\
Argélia & $-0,291$ \\
Azerbaijão & $-0,865$ \\
Brasil & 4,012 \\
Colômbia & $-3,433$ \\
Croácia & 1,595 \\
República Dominicana & $-0,630$ \\
Emirados Árabes Unidos & $-4,031$ \\
Equador & 0,980 \\
Filipinas & $-1,510$ \\
Hungria & $-0,127$ \\
México & $-0,014$ \\
Marrocos & 1,282 \\
Omã & $-5,976$ \\
Peru & 1,680 \\
Polônia & $-2,418$ \\
Romênia & 0,264 \\
Turquia & $-3,920$ \\
Uruguai & $-1,241$ \\
\hline Fonte: FMl. Elaboracão própria &
\end{tabular}

Em comparação com a metodologia anterior, há um aumento significativo do diferencial para países como Argélia e Azerbaijão que se deve, principalmente, ao o elevado crescimento que estes países tiveram nos $2000 \mathrm{e}$ que acabaram fazendo com que sua média fosse afetada. Entretanto, para a maioria dos países, os resultados foram pouco alterados.

Abaixo, apresentamos os resultados do limite de endividamento para 0 caso determinista. 
Tabela 19: Espaço Fiscal e Limite de Endividamento para o caso determinista pelo método do juros estrutural e do crescimento potencial (em \% do PIB)

\begin{tabular}{cccc}
\hline País & Dívida Atual & Espaço Fiscal & $\begin{array}{c}\text { Limite de } \\
\text { Endividamento }\end{array}$ \\
\hline África do Sul & 51,6 & 103,2 & 154,8 \\
Argélia & 20,4 & 139,1 & 159,5 \\
Azerbaijão & 50,7 & 104,6 & 155,3 \\
Brasil & 78,4 & 48,7 & 127,1 \\
Colômbia & 49,8 & 106,8 & 156,6 \\
Croácia & 82,3 & 60,7 & 143,0 \\
República & 34,6 & 126,8 & 161,4 \\
Dominicana & & & 128,4 \\
Emirados Árabes & 20,2 & 108,2 & 158,8 \\
Unidos & 43,2 & 115,6 & 168,5 \\
Equador & 39,0 & 129,5 & 147,2 \\
Filipinas & 76,0 & 71,2 & 158,1 \\
Hungria & 56,8 & 101,3 & 149,9 \\
México & 64,9 & 85,0 & 162,6 \\
Marrocos & 32,5 & 130,1 & 150,8 \\
Omã & 24,5 & 126,3 & 141,9 \\
Peru & 54,2 & 87,7 & 139,7 \\
Polônia & 38,8 & 100,9 & 160,0 \\
Romênia & 28,3 & 131,7 & 159,0 \\
Turquia & 61,6 & 97,4 & 151,7 \\
Uruguai & 47,8 & 103,9 & 155,3 \\
Média & 49,8 & 104,6 & \\
Mediana & & &
\end{tabular}

Fonte: FMI. Elaboração própria

Observamos que, apesar da diferença entre alguns países, o resultado geral pouco se altera, sendo a média e a mediana levemente inferiores à quando o diferencial era calculado pela média dos últimos 11 anos. Além disso, Brasil, Croácia e Hungria continuam sendo os países com o menor espaço fiscal, mas, ainda assim, em situação confortável. Abaixo, apresentamos o limite para o caso estocástico 
Tabela 20: Espaço Fiscal e Limite de Endividamento para o caso estocástico pelo método do juro estrutural e do crescimento potencial (em \% do PIB)

\begin{tabular}{cccc}
\hline País & Dívida Atual & Espaço Fiscal & Limite de Endividamento \\
\hline África do Sul & 51,6 & 78,4 & 130,0 \\
Argélia & 20,4 & 103,7 & 124,1 \\
Azerbaijão & 50,7 & 56,4 & 107,1 \\
Brasil & 78,4 & 29,5 & 107,9 \\
Colômbia & 49,8 & 72,4 & 122,2 \\
Croácia & 82,3 & 26,2 & 108,5 \\
República & 34,6 & 105,0 & 139,6 \\
Dominicana & & & \\
Emirados Árabes & 20,2 & - & - \\
Unidos ${ }^{38}$ & 43,2 & 95,2 & 138,4 \\
Equador & 39,0 & 110,0 & 149,0 \\
Filipinas & 76,0 & 63,2 & 139,2 \\
Hungria & 56,8 & 78,5 & 135,3 \\
México & 64,9 & 58,9 & 123,8 \\
Marrocos & 32,5 & 94,8 & 127,3 \\
Omã & 24,5 & 113,4 & 137,9 \\
Peru & 54,2 & 81,1 & 135,3 \\
Polônia & 38,8 & 61,4 & 100,2 \\
Romênia & 28,3 & 100,9 & 129,2 \\
Turquia & 61,6 & 53,1 & 114,7 \\
Uruguai & 47,8 & 77,2 & 126,5 \\
Média & 49,8 & 78,5 & 128,5 \\
Mediana & & &
\end{tabular}

Fonte: FMI. Elaboração própria

Assim como no caso determinista, a média e a mediana pouco se alteraram. Já para os países em pior situação, o Brasil apresentou uma melhora considerável, não sendo mais o país com o pior espaço fiscal ainda que seu espaço fiscal permaneça abaixo do valor de $30 \%$ do PIB. A Croácia, devido ao aumento em seu diferencial, reduziu um pouco seu limite fiscal, se tornando agora o país com o pior espaço fiscal. Para o restante dos países, apesar das mudanças que levaram a aumentos ou reduções em seus espaços fiscais, não parece haver uma situação preocupante para nenhum deles.

\footnotetext{
${ }^{38}$ Não foi possível obter o limite de endividamento para os Emirados Árabes Unidos.
} 
Portanto, a situação fiscal, para caso determinista, em termos de limite de endividamento e espaço fiscal para os países emergentes, não é tão preocupante. Mesmo para aqueles que possuem espaço ou limite baixos, a diferença ainda é grande o suficiente para sejam adotadas medidas que permitam uma melhora nestes valores ao longo dos próximos anos. Entretanto, quando verificamos para o caso estocástico, ainda que para a maioria dos países a situação continue pouco preocupante, para Brasil e Croácia o espaço fiscal é muito baixo, tornando urgente medidas que reduzam o nível de endividamento destes países nos próximos anos ${ }^{39}$.

\subsection{Conclusão}

Em um contexto de piora no resultado fiscal de alguns países emergentes, torna-se relevante verificar qual o valor máximo de endividamento e qual a distância entre este e o valor atual que um grupo de países possui.

Com este problema em mente, este trabalho faz uso da metodologia empregada por Ghosh et al. (2013) estimando uma função de reação fiscal com dados em painel para o resultado primário dos países sendo explicado pelo nível de endividamento defasado e uma série de outras variáveis explicativas compreendendo o período de 2003 a 2016.

Para a nossa amostra, preferimos restringi-la um pouco mais na tentativa de conseguir uma estimação que tenha um grupo de países mais homogêneo possível. Essa homogeneidade, em termos do parâmetro de reação fiscal para o nível de endividamento, foi testada e confirmada tanto para países com nível de endividamento baixo-médio e médio-alto.

Verificou-se a existência da hipótese de fadiga fiscal para os países analisados. Pelos resultados obtidos, esta hipótese foi confirmada e corroborada por diversos testes de robustez que procuram alterar a metodologia de

\footnotetext{
${ }^{39}$ No Anexo A.2 refizemos os exercícios para o caso determinista e estocástico e para as metodologias de média e juros estrutural com crescimento potencial, utilizando a taxa de juros básica da economia de cada país, ou, ao menos, a taxa de juros de referência. Apesar do resultado diferir para alguns países individualmente, os resultados para a média e mediana não apresentaram grandes modificações, mostrando que os resultados obtidos são robustos a outras metodologias de estimação da taxa de juros. Dentre os casos individuais, destaca-se o caso do Brasil que, com o menor diferencial de taxa de juros e crescimento econômico, apresentou um espaço fiscal superior ao observado na análise original. Enquanto a Croácia teve uma redução significativa em seu espaço fiscal.
} 
estimação e especificação da função. A fadiga fiscal para países se inicia para níveis de endividamento em torno de $70 \%$ do PIB e a resposta marginal ao aumento do endividamento se torna negativa em torno de $110 \%$ do PIB. Estes resultados são significativamente inferiores aos observados em países desenvolvidos, mesmo quando levamos em consideração os intervalos de confiança para o início da fadiga fiscal e quando a resposta marginal se torna negativa.

Além disso, tratamos um possível problema de causalidade reversa existente entre o resultado primário e o endividamento utilizando a metodologia de variável instrumental e, tendo como instrumento, a média até a quinta defasagem do endividamento. Como resultado, observamos que nossa hipótese de fadiga fiscal se manteve mesmo neste contexto, além de ter se mantido para outras especificações e métodos de estimação.

Por fim, combinamos o resultado estimado para a função de reação fiscal e o diferencial entre taxa de juros e crescimento econômico na média de 11 anos (2006 a 2016) para encontrarmos o nível máximo de endividamento dos países. Para o caso determinista, os resultados indicaram níveis de endividamento máximos com média em torno de $154,1 \%$ do PIB, valor inferior ao obtido para países desenvolvidos e bem acima do nível médio atual de endividamento em países emergentes, de $47,8 \%$ do PIB. Mesmo individualmente, o espaço fiscal é elevado, inclusive para países que possuem o menor espaço fiscal da amostra. Entretanto, para o caso estocástico, que, em nossa opinião, reflete melhor a situação dos países, há uma redução significativa no limite de dívida e no espaço fiscal. Ainda que para a maioria dos países a situação fiscal continue pouco preocupante, para Brasil e Croácia, o espaço fiscal é baixo, indicando a necessidade destes países realizarem ajustes nos próximos anos que possibilitem a redução no seu nível de endividamento. Posteriormente, calculamos o diferencial por meio da metodologia de juros estrutural e produto potencial e os resultados poucos se alteraram, ainda que o Brasil tenha apresentado um maior espaço fiscal, enquanto a Croácia teve uma redução nesta métrica. Os resultados são corroborados para o uso de outra métrica de juros real, focada na taxa de juros básica da economia, com pequena variação para os juros médio e mediano, em relação à estimação original, e uma variação um pouco maior para alguns países isoladamente. 


\section{Efeito não linear do endividamento público sobre o crescimento econômico: Uma análise para países emergentes}

\subsection{Introdução}

O endividamento público é uma prática comum desde o início da formação das nações como um importante instrumento que tornou possível financiar suas despesas. Entretanto, como no passado seu uso esteve muito relacionado à necessidade de financiar guerras, sua maturidade era curta e sua negociação restrita a pessoas ricas (Dyson, 2014). Já nos dias de hoje é amplamente negociado no mercado financeiro, possui diversas maturidades e sua principal função é financiar déficits orçamentários (Salsman, 2017).

Como apresentado na introdução desta tese, nos últimos anos houve uma deterioração significativa nos indicadores fiscais do Brasil. Além disto, o país não foi um caso isolado dentre os emergentes, com outros países deste grupo passando por uma deterioração de suas contas públicas, principalmente após a crise financeira de 2008.

Esta deterioração acaba tendo efeitos significativos sobre o crescimento econômico destes países. O primeiro e mais claro efeito se dá via o aumento da taxa de juros real do país, devido ao aumento da sua probabilidade de default do país (Codogno et al., 2003), que acaba levando a uma menor taxa de investimento (Chouraqui et al., 1986; Tanzi e Chalk, 2000; Laubach, 2009; Checherita-Westphal e Rotter, 2012). Outro canal é via o aumento da incerteza ou criar expectativas sobre uma futura repressão financeira (Cochrane, 2011; Reinhart, 2012).

Entretanto, um problema existente na literatura sobre este tema é que assim como o endividamento pode ter efeito sobre o crescimento econômico, este também afeta o endividamento, como via uma taxa de crescimento menor ou, uma terceira variável, como crise uma crise bancária pode afetar crescimento e endividamento conjuntamente. Logo, se faz necessário tratar este problema de 
causalidade reversa para que seja possível realizar uma análise sem viés. Para resolver esta questão, se faz uso na literatura de variáveis instrumentais para capturar o efeito do endividamento sobre o crescimento econômico.

Portanto, levando em consideração a deterioração fiscal observada em alguns países emergentes e o problema de causalidade reversa que pode ser resolvido via o método desenvolvido por Checherita-Westphal e Rotter (2012), que utiliza a média do endividamento dos outros países na amostra para o respectivo ano como variável instrumental para o país que tem seu endividamento instrumentalizado, o objetivo deste ensaio é verificar se para um grupo de 36 países emergentes para o período de 1990 a 2017 se o nível de endividamento possui efeito negativo sobre o crescimento, além de verificar se este efeito é não linear. Com isso, este ensaio busca contribuir para a literatura sobre o tema em diversos aspectos: i. Levando em consideração o problema de causalidade reversa existente entre endividamento e crescimento econômico, realizar regressões via Método Generalizado de Momentos utilizando variáveis instrumentais desenvolvidas na literatura recente, ao contrário da maioria dos trabalhos sobre emergentes que não levam esta causalidade reversa em consideração; ii. Utilizarmos a dívida bruta para os países emergentes, ao contrário da maioria dos trabalhos que focam no endividamento externo ${ }^{40}$; iii. Buscarmos uma maior homogeneidade entre os países, para isso utilizaremos uma lista mais restrita de países, evitando potenciais problemas de heterogeneidade na amostra, como apontado por Checherita-Westphal e Rotter (2012), dado que a grande maioria dos artigos sobre emergentes utilizam um grupo grande de países; iv. Utilizarmos uma série de exercícios de robustez que confirmam os resultados encontrados para as nossas regressões principais tanto em termos do efeito do endividamento sobre o crescimento econômico, quanto sobre a estabilidade do ponto de reversão; v. Verificarmos como esta relação entre crescimento econômico e endividamento pode ser afetado por países que possuem níveis elevados de investimento público, logo verificar se para países

\footnotetext{
${ }^{40}$ Como forma de robustez e até para tornar comparável com os trabalhos anteriores, faremos a regressão com o endividamento externo. Além disso, como mostrado em Panizza (2008), ao longo das últimas décadas a dívida interna se tornou mais representativa para países emergentes, portanto faz mais sentido utilizar o endividamento bruto total, do que, apenas, a dívida externa.
} 
que poderiam aumentar sua dívida para ampliar o investimento público há alguma alteração na relação entre crescimento econômico e endividamento. Além de verificar se maiores níveis de democracia nos países alteram a relação entre crescimento econômico e endividamento.

Como resultado, observamos que não há relação entre taxa de crescimento econômico no ano seguinte para o efeito linear e não linear quando não levamos em consideração a existência de causalidade reversa entre estas variáveis. Entretanto, quando levamos este efeito em consideração e realizamos as regressões com variáveis instrumentais via a metodologia de Métodos Generalizados de Momento, verificamos que há uma relação negativa entre taxa de crescimento econômico e endividamento bruto, assim como esta relação apresenta uma não linearidade no formato de $U$ invertido, tanto para 0 crescimento anual, que seria o resultado de curto prazo, quanto para o crescimento de cinco anos, que seria o resultado de médio prazo. Para este ponto de máximo do efeito do endividamento sobre o crescimento econômico, as nossas diversas estimações indicam que este valor está entre 40-60\% do PIB, tanto para o curto quanto o médio prazo, significativamente inferior àquele observado para países desenvolvidos, cujos trabalhos que encontram não linearidade indicam um valor entre $70-100 \%$ do PIB.

Por fim, realizamos testes de robustez que mostram que nossos resultados são robustos mesmo para problemas de heterocedasticidade e autocorrelação; para exclusão de outliers do endividamento, tanto para os que possuem o menor quanto o maior endividamento; para a adição do crédito privado, como proxy do endividamento privado; e para o crescimento de 10 anos. Além disso, alterações do polinômio do endividamento não levou a grandes alterações no ponto de reversão, e a alteração na taxa de crescimento do PIB per capita de PPP para crescimento real em moeda nacional pouco alterou nosso resultado. Para o caso da dívida externa, pública mais privada, não encontramos evidências de não linearidade, assim como não observamos impacto na variação do endividamento interno sobre o crescimento econômico. Por fim, observamos que para países com mais democracia o ponto de reversão se encontra em um nível maior de endividamento em comparação a países com menos democracia. Já para o efeito do endividamento sobre crescimento para países com 
investimento público alto o resultado é positivo, isto é, mais endividamento leva a maior crescimento, enquanto que para aqueles que possuem investimento público baixo os resultados são semelhantes à reversão observada anteriormente. Entretanto, este resultado não é corroborado para outras especificações no método de estimação nem para outras formas de medir o investimento público.

Este ensaio está divido em seis seções. Esta seção introdutória, seguida da revisão de literatura sobre o impacto do elevado endividamento sobre crescimento. Na terceira seção é apresentada a metodologia a ser utilizada e na quarta, os resultados. Na quinta seção são apresentados os testes de robustez para os países analisados. Por fim, é apresentada uma breve conclusão.

\subsection{Revisão de Literatura}

A abordagem dos efeitos do endividamento sobre o crescimento econômico possui uma ampla literatura tratando sobre o tema. $O$ início deste tema surge com Diamond (1965) que, por meio de um modelo teórico, verifica o equilíbrio competitivo de longo prazo em um modelo de crescimento e verifica os efeitos do endividamento neste equilíbrio. Saint-Paul (1992) formula um modelo de crescimento endógeno com retornos constantes de capital em que um crescimento da dívida pública leva a uma redução da taxa de crescimento econômico e, portanto, sempre haverá uma geração futura que será afetada por este aumento do endividamento.

Em um contexto de modelos de teóricos de equilíbrio geral, Bernanke e Gertler (1990) chegam a resultados em que aumentos nominais no nível de endividamento levam a um aumento na volatilidade, na fragilidade financeira e reduzem o crescimento médio da economia.

A análise empírica sobre o tema começou a ter maior destaque com o estudo elaborado por Barro (1979) para a relação entre endividamento e impostos sobre a atividade econômica. Como resultado, o autor observou que não há efeito do movimento do endividamento sobre a atividade econômica. 
Smyth e Hsing (1995) buscam obter o nível de dívida que maximiza o crescimento econômico. Para isso, os autores analisam a economia dos Estados Unidos para o período de 1960 a 1991 e, por meio de uma análise de cointegração, verificam se há uma relação de longo prazo entre crescimento econômico, endividamento e endividamento ao quadro e uma série de outras variáveis de controle. Como resultado, observam que há uma relação de longo prazo e o nível ótimo de endividamento é de $48,9 \%$ da dívida total, que está abaixo do nível atual da dívida americana. É importante notar que este é um dos primeiros estudos a verificar a possibilidade de não linearidade entre endividamento e crescimento econômico.

Dentre os primeiros trabalhos que verificam a relação não linear entre endividamento e crescimento econômico para países em desenvolvimento, destacam-se os trabalhos para países africanos e da América Latina de Cohen (1997), e de Elbadawi et al. (1997) para países da África subsaariana. Ambos utilizam como métrica para endividamento a dívida externa dos países ${ }^{41}$ e encontram evidências dessa não linearidade.

Patillo et al (2002) analisam para 93 países em desenvolvimento para o período de 1969 a 1998 a relação entre endividamento externo e o crescimento econômico, por meio de diversas metodologias. Como conclusão, o estudo encontra evidências de uma relação não linear entre endividamento e crescimento. Níveis pequenos de endividamento auxiliam no crescimento econômico, entretanto, a partir de níveis entre 35 - 40\% do PIB de endividamento essa relação se inverte e um aumento nesta métrica leva a uma redução no crescimento econômico.

Schclarek (2004) analisa a relação entre endividamento e crescimento para 59 países em desenvolvimento e 24 países industriais para o período entre 1970 e 2002. Como metodologia, o autor utiliza o painel dinâmico desenvolvida por Arellano e Bover (1995). Para os países em desenvolvimento, o autor encontra que uma menor dívida externa implica em maior crescimento econômico, entretanto não encontra nenhuma evidência de não linearidade entre

${ }^{41}$ Cohen (1997) não chega a utilizar diretamente a dívida externa, mas utiliza uma métrica equivalente que seria a probabilidade do país ter um evento de default medido em seu endividamento externo. 
endividamento e crescimento. Para os países industriais, o autor não encontrou nenhuma evidência de relação entre as variáveis.

Reinhart e Rogoff (2010) realizaram um dos trabalhos mais famosos associando nível de endividamento dos países e taxa de crescimento. Os autores realizaram o estudo separando para países desenvolvidos e países emergentes, sendo o primeiro uma amostra de 20 países e o segundo uma amostra de 24 países. Para os países desenvolvidos, a amostra parte de dados de 1946 a 2009 e encontraram que, a partir dos níveis de endividamento acima de $90 \%$ do PIB, o nível mediano de crescimento é $1 \%$ menor que os países com baixo nível de endividamento, enquanto o nível médio chega a ser $4 \%$ menor no crescimento. Para os países emergentes, o crescimento médio e mediano fica entre 4 e 4,5\% para países com nível de dívida inferior a $90 \%$ do PIB, enquanto para países com nível de endividamento acima de $90 \%$ do PIB o crescimento mediano se reduz para 2,9\%, e o crescimento médio se reduz ainda mais, para próximo de 1\%. Além da dívida interna, os autores analisam, também, níveis de dívida externa para países emergentes e verificam que o limite é ainda menor, sendo que os efeitos negativos sobre o crescimento se iniciam em níveis próximos a $60 \%$ do PIB. Entretanto, como mostrado em Herndon et al. (2014), a base de dados utilizada por Reinhart e Rogoff (2010) continha erros, e quando estes erros foram devidamente corrigidos os efeitos do endividamento elevado sobre 0 crescimento se reduziram dramaticamente. Para os países desenvolvidos o efeito médio sobre o crescimento é de 1,5\% menor e não 4\% menor como mostrado originalmente e, com isso, quando este grupo de países possui nível de endividamento superior a $90 \%$ do PIB, os efeitos não são tão drásticos. Entretanto, ambos os estudam confirmaram que há uma relação não linear e negativa entre taxa de crescimento e nível de endividamento.

Caner et al. (2010) analisam os dados de 99 países desenvolvidos e em desenvolvimento para o período de 1980 a 2008. As estimações indicam não linearidade e os efeitos negativos se iniciam por volta do nível de 77\% do PIB, além de um aumento 1 ponto na dívida levar a uma redução de 0,017 no crescimento. Este efeito é ainda mais evidente em países emergentes, em que o nível de endividamento que começa a ter efeitos negativos sobre o crescimento 
se dá em torno de $64 \%$ do PIB e o efeito do aumento de 1 ponto na dívida leva a uma redução de 0,02 no crescimento

Entretanto, diversos trabalhos começaram a indicar a existência de causalidade reversa entre crescimento econômico e endividamento. Com isso, começaram a utilizar diferentes maneiras para conseguir lidar com este problema.

Kumar e Woo (2010) realizam a análise para países desenvolvidos e em desenvolvimento para um período de, aproximadamente, quatro décadas. Para lidar com o problema de causalidade reversa, os autores utilizam uma metodologia de estimação por GMM com instrumentos internos. Como resultado, os autores obtêm que um aumento em 10 pontos no endividamento leva a uma redução de 0,2 pontos no crescimento anual, com este impacto sendo menor em países desenvolvidos em relação a países em desenvolvimento. Por fim, os autores ainda encontram evidências de que há uma não linearidade na relação entre crescimento e endividamento para níveis elevados de dívida.

Cecchetti et al. (2011a) utilizam dados de 18 países da OCDE para 0 período de 1980 a 2010 para analisar o impacto do endividamento sobre o crescimento. Para lidar com o problema de causalidade reversa, os autores utilizam variáveis defasadas da relação dívida/PIB. Como resultado, encontram que para níveis de endividamento superiores a $85 \%$ do PIB, os efeitos do endividamento sobre o crescimento começam a ser negativos.

Checherita-Westphal e Rotter (2012) analisam o impacto do endividamento sobre o crescimento do PIB per capita em 12 países da zona do euro para o período de 1970 a 2010. Para lidar com o problema de causalidade reversa, os autores utilizam como instrumento a média da relação dívida/PIB dos outros países da amostra. Como resultado, encontram uma relação não linear entre endividamento e crescimento, sendo que o efeito negativo se inicia para valores de endividamento entre 90 e $100 \%$ do PIB. Os canais pelos quais existe essa não linearidade são a poupança privada, investimento público e produtividade total dos fatores. 
Panizza e Presbitero (2014) verificam se há uma relação entre crescimento econômico e endividamento para um grupo de 18 países da OCDE. Para lidar com o problema de causalidade reversa, os autores propõem como variável instrumental para o endividamento utilizar o efeito valorização vindo da interação entre a dívida externa em moeda estrangeira e os movimentos na taxa de câmbio. Como resultado, os autores não encontram uma relação entre endividamento e crescimento econômico. Para confirmar o resultado, são realizados diversos testes de robustez que mostram que os resultados não são afetados pelo problema de instrumentos fracos e são robustos ao se relaxar a restrição de exclusão.

Afonso e Alves (2014) analisam os efeitos do endividamento público sobre o crescimento econômico anual e a média de crescimento de 5 anos, assim como a possibilidade de existência de não linearidade entre endividamento e crescimento para 14 países europeus entre 1970 e 2012. Como resultado, os autores observam um impacto negativo de $0,01 \%$ sobre o crescimento para cada aumento de $1 \%$ no endividamento. Além disso, os autores encontraram que para este grupo de países há evidências de não linearidade, com o crescimento se reduzindo para níveis de endividamento superiores a $75 \%$ do PIB. Por fim, a zona do Euro teve um efeito de redução de 0,5\% no crescimento, enquanto, dentre as crises, a que tem pior efeito é a crise bancária.

Eberhardt e Presbitero (2015) analisam a relação entre crescimento e endividamento para 118 países entre o período de 1961 a 2012. Para modelar esta relação, os autores utilizam um estimador que leva em consideração a heterogeneidade entre países, além de adotarem uma especificação linear e não linear. Como resultado, os autores encontram uma relação negativa entre endividamento e crescimento, mas não encontram evidências de que haja uma relação não linear.

Fincke e Grainer (2015) analisam a relação entre crescimento e endividamento para oito países emergentes utilizando técnicas de efeitos fixos e efeitos aleatórios para o período de 1980 a 2012. Como resultado, os autores encontraram uma relação positiva entre endividamento e crescimento, ao contrário do resultado obtido para outros estudos. 
Camuri (2015) busca fazer uma ampla análise da relação entre endividamento público e crescimento econômico. Primeiramente, o trabalho procurou retomar, por meio de uma base de dados distinta, replicar o trabalho de Reinhart e Rogoff (2010) e Herndon et al. (2014) mostrando que as conclusões obtidas para estes trabalhos não se mostram verdadeiras para esta nova base e com as correções necessárias aos trabalhos, sendo que os limiares do efeito do endividamento sobre o PIB não se mostram corretos, além de compararem outras variáveis com relação ao nível de endividamento. Além disso, o trabalho busca, por meio de modelos econométricos, analisar a relação entre crescimento e endividamento. Por meio do método de Painel Longo, o autor realiza análises robustas a heterocedasticidade e problemas de autocorrelação, encontrando que o endividamento possui efeitos negativos no crescimento, apesar destes efeitos serem menores em países emergentes em comparação a países desenvolvidos. Entretanto, quando considera a dependência cross section e as diferentes direções de causalidades possíveis, estes resultados podem variar de país para país, sendo que para alguns o efeito do endividamento sobre o crescimento é positivo, enquanto para outros este efeito é negativo. Portanto, para alguns países, a sugestão tradicional de ajuste fiscal para levar ao crescimento econômico futuro não faria sentido, principalmente para os países emergentes.

Chudik et al. (2017) utilizam modelos de painel dinâmico heterogêneo com erros dependentes em corte transversal para 40 países no período de 1965 a 2010. Como resultado, os autores não encontraram um ponto universal de limite para crescimento econômico e endividamento. Apesar de não encontrar este ponto, os autores chegam a uma relação negativa entre endividamento e crescimento econômico.

Saeed e Islam (2018) analisa para países em desenvolvimento da Ásia para o período de 1980 a 2014 e encontram que há uma relação positiva e estatisticamente significante entre crescimento e endividamento levando em consideração a possibilidade de não linearidade, que não se mostrou significante, e o problema de endogeneidade devido à causalidade reversa. 
Portanto, a maioria dos resultados na literatura indicam que há uma relação negativa entre endividamento e crescimento econômico, apesar de resultados mais recentes indicarem uma relação positiva ou não indicarem relação alguma. Um ponto ainda mais nebuloso é que não há uma conclusão sobre se há uma não linearidade nesta relação. Além disso, a maioria dos trabalhos foca a análise para países desenvolvidos e nos trabalhos para países emergentes foca-se na dívida externa e, apenas recentemente, começou a se levar em consideração o fato de que há uma relação de causalidade reversa entre crescimento e endividamento. Logo, este ensaio buscará focar sua análise em um grupo de países emergentes, levando em consideração a questão da causalidade reversa e utilizando as técnicas mais recentes para tratá-la.

\subsection{Metodologia e Base de Dados}

Após termos apresentado uma revisão de literatura que demonstra como o tema do nível endividamento elevado reduz o crescimento dos países ganhou relevância, principalmente após a crise financeira e com o trabalho de Reinhart e Rogoff (2010), iremos, nesta seção, abordar a base de dados utilizada com os países e o período escolhido para a estimação. Além disso, apresentaremos a metodologia empírica para obtenção dos resultados.

\subsubsection{Base de Dados}

Para selecionarmos os países emergentes da nossa amostra, partimos do Fiscal Monitor do FMI $(2017)^{42}$ que seleciona 39 países classificados como emergentes e de renda média e abordam alguns indicadores fiscais destes países. A opção por uma amostra menor de países em relação aos outros trabalhos que tratam de países em desenvolvimento, se deve ao fato de

\footnotetext{
${ }^{42}$ A opção pelo estudo do FMI se deve ao fato de utilizarmos a base de dados desta instituição para obtermos a grande maioria dos indicadores utilizados na estimação da nossa função de reação fiscal. Além disso, como há uma grande dificuldade em definir quais países podem ser classificados como emergentes, preferimos seguir a recomendação desta instituição que possui amplo conhecimento na situação particular de cada país.
} 
querermos evitar a questão da heterogeneidade que pode levar a problemas nas regressões padrão de crescimento (Checherita-Westphal e Rotter, 2012).

Destes 39 países, excluímos três ${ }^{43}$ países da base de dados e fazemos nossas estimações para os seguintes 36 países: África do Sul, Argélia, Angola, Argentina, Azerbaijão, Brasil, Bielorrússia, Cazaquistão, Chile, China, Colômbia, Croácia, República Dominicana, Emirados Árabes Unidos, Equador, Egito, Filipinas, Hungria, Índia, Indonésia, Irã, Kuwait, Malásia, México, Marrocos, Omã, Paquistão, Peru, Polônia, Romênia, Rússia, Sri Lanka, Tailândia, Turquia, Ucrânia e Uruguai. ${ }^{44}$

Nossos dados se iniciam a partir de 1990 e vão até $2017^{45}$. Os dados são retirados do World Economic Outlook do FMI (2019) e do Banco Mundial (2019). Apresentamos no Anexo A as estatísticas descritivas das nossas variáveis.

\subsubsection{Metodologia}

Um dos grandes problemas nos trabalhos teóricos e, principalmente, empíricos sobre a relação entre crescimento e endividamento é que sempre se levou em consideração o fato de que há uma correlação negativa entre crescimento econômico e nível de endividamento, e se pressupôs que esta correlação seria derivada de um efeito negativo do endividamento sobre 0 crescimento.

Entretanto, correlação não implica, necessariamente, em causalidade e a ligação desta relação poderia estra relacionado ao fato que uma taxa de

\footnotetext{
${ }^{43}$ Forma excluídos os seguintes países: Venezuela, devido aos dados extremamente defasados (o último dado oficial para resultado primário é de 2013) e a baixa confiança nos dados oficiais; Líbia, pois o país não possui dados de dívida bruta e Qatar, pois não possui dados de inflação na base de dados.

${ }^{44}$ Não é possível garantir que estes países correspondem a melhor amostra possível de países emergentes para nossa estimação e podem surgir críticas com relação à inclusão ou exclusão de algum país. Para minimizarmos estas críticas, preferimos não seguir um padrão próprio para a seleção dos países, mas, sim, a seleção realizada pelo FMI que possui um nível de conhecimento muito superior ao nosso sobre as características de cada país.

${ }^{45}$ Este é o último em que há dados oficiais para todos os países. A partir de 2018, alguns países ainda possuem resultados estimados pelo FMI. A opção por 1990 se deve ao fato que quase não há dados de endividamento e resultado primário para o período anterior a este e mesmo para 0 período posterior a 1990, alguns países somente apresentarão dados posteriormente, inclusive por aqueles países da amostra que só vieram a existir posteriormente ao fim da URSS.
} 
crescimento econômico menor poderia levar a níveis mais elevados de endividamento (Reinhart et al, 2012). Empiricamente, dívida em proporção do PIB leva, automaticamente, a uma correlação negativa entre dívida e crescimento, e esta pode ser amplificada pela presença de estabilizadores automáticos ou via política fiscal discricionária anticíclica. Há, também, um terceiro fator que poderia levar a esta correlação negativa como algo que possa afetar conjuntamente as duas variáveis, como uma crise bancária que acaba afetando as duas variáveis conjuntamente (Reinhart e Rogoff, 2011) ou alterações políticas que podem alterar os rumos da política fiscal impactando tanto endividamento quanto crescimento. Com isso, temos um problema claro de causalidade reversa existente nas estimações que não levam em consideração os pontos citados acima.

Portanto, para estabelecer a ligação causal do endividamento afetando a taxa de crescimento econômico, há a necessidade do uso de variáveis instrumentais encontrando um instrumento que tenha efeito direto sobre 0 endividamento e indireto, via endividamento, sobre o crescimento.

É dentro deste contexto que surgem os trabalhos de Kumar e Woo (2010), Checherita-Westphal e Rotter (2012) e Panizza e Presbitero (2014), que fazem uso de variáveis instrumentais para verificar os efeitos do nível de endividamento sobre o crescimento econômico.

Como método de regressão em nossas estimações principais faremos uso do Método de Momentos Generalizados (GMM) que possibilita a correção de heterocedasticidade e autocorrelação na estrutura do termo de termo ao utilizar o estimador consistente. Além disso, o GMM em dois estágios apresenta ganhos de eficiência sobre o estimador de dois estágios devido ao uso da matriz de pesos ótima para modelos com restrições sobreidentificadas.

Abaixo, apresentamos a equação que será estimada que tem como base a estimação realizada por (Checherita-Westphal e Rotter, 2012):

$$
\begin{gathered}
g_{i t+k}=\beta_{0}+\beta_{1} \text { dívida }_{i t}+\beta_{2} \text { dívida }^{2}+\beta_{3} \ln (\text { PIB per capita })_{i t}+\beta_{4} \text { Inv }_{i t} \\
+\beta_{5} \text { CrescPop }_{i t}+\gamma Z_{i t}+\mu_{i}+\theta_{t}+\varepsilon_{i t}
\end{gathered}
$$


Em que $g_{i t+k}$ é a taxa de crescimento do PIB per capita em Paridade de Poder Compra (Pattillo, 2002) e $k=1$ ou 5. Para $k=1$ estamos fazendo o crescimento anual e para $k=5$ estamos fazendo a taxa de crescimento acumulada de 5 anos. Seguindo o modelo de crescimento econômico empírico baseado na equação de convergência condicional, a taxa de crescimento do PIB per capita é explicada pelo logaritmo do nível inicial de renda per capita $\ln$ (PIB per capita), seguindo os estudos de Pattillo (2002), Checherita-Westphal e Rotter (2012), Panizza e Presbitero (2014) e Fincke e Grainer (2015) ${ }^{46}$; o investimento em \% do PIB (Inv), seguindo Pattillo (2002) e Fincke e Grainer (2015); e a taxa de crescimento populacional (CrescPop), seguindo Pattillo (2002), Checherita-Westphal e Rotter (2012), Panizza e Presbitero (2014) e Fincke e Grainer (2015).

Para verificarmos o efeito da dívida sobre o crescimento, adicionamos 0 endividamento bruto do governo em \% do PIB no nível ${ }^{47}$ e, para verificar uma possível não linearidade, é adicionado o nível de endividamento bruto ao quadrado. Ao contrário da maioria dos trabalhos para países emergentes, optamos por utilizar o endividamento interno bruto, pois como apresentado em Panizza (2008) a dívida pública interna nos países emergentes vem adquirindo maior importância, passando de $20 \%$ para $30 \%$ do PIB dos anos 90 para os anos 2000 , enquanto a dívida externa se reduziu por volta de $20 \%$ para $10 \%$ para o mesmo período. Portanto, tornou-se importante ao longo dos anos levar em consideração o endividamento interno total dos países emergentes, e não somente o endividamento externo.

Para as variáveis de controle existentes no vetor $Z_{i t}$, temos o resultado primário em \% do PIB para possíveis efeitos fiscais sobre a taxa de crescimento do PIB per capita, seguindo Pattillo (2002) e Checherita-Westphal e Rotter (2012); abertura econômica (soma de exportações e importações em \% do PIB)

\footnotetext{
${ }^{46}$ Para a seleção das melhores variáveis explicativas, optamos por observar quais foram utilizadas nos dois principais trabalhos que fazem uso de variáveis instrumentais e em dois importantes trabalhos que realizam a análise para países emergentes.

${ }^{47} \mathrm{~A}$ opção pelo uso do endividamento bruto em contraponto ao endividamento líquido, se deve ao fato que o endividamento líquido depende dos descontos dos créditos e, em muitos casos, as metodologias utilizadas diferem entre os países, logo os resultados acabam não sendo comparáveis. Apesar de problemas metodológicos também afetarem a dívida bruta, estes são inferiores aos observados para a dívida líquida.
} 
para capturar possíveis ganhos de produtividade do comércio internacional, seguindo Pattillo (2002), Checherita-Westphal e Rotter (2012) e Panizza e Presbitero (2014); taxa de inflação, seguindo Reinhart e Rogoff (2010), Panizza e Presbitero (2014), Fincke e Grainer (2015) ; variável dummy igual 1 se houve crise bancária no período $\mathrm{t}+\mathrm{k}$ ou 0 caso contrário; variável dummy igual 1 se houve crise cambial no período $\mathrm{t}+\mathrm{k}$ ou 0 caso contrário e variável dummy igual 1 se houve crise soberana no período $\mathrm{t}+\mathrm{k}$ ou 0 caso contrário ${ }^{48}$; crescimento mundial em $\mathrm{t}+\mathrm{k}$ como controle para choques externos que venham afetar 0 crescimento dos países. Além disso, $\mu_{i}$ mede efeitos fixos para país, $\theta_{t}$ efeitos fixos para tempo e $\varepsilon_{i t}$ que é o termo de erro idiossincrático ${ }^{49}$.

Para instrumentarmos a variável de endividamento e endividamento ao quadrado seguiremos o método utilizado por Checherita-Westphal e Rotter (2012), que utiliza a média do endividamento dos outros países na amostra para o respectivo ano como instrumento para o país que tem o seu endividamento sendo instrumentalizado ${ }^{50}$. Conforme apresentado em Wooldridge (2016), uma variável instrumental deve apresentar como características não possuir correlação com o termo de erro e possuir correlação com a variável a qual está instrumentando. Além disso, para ser um bom instrumento, a variável instrumental deverá possuir uma correlação minimamente razoável com a variável que está instrumentando, sob o risco de possuir um elevado viés assimptótico, caso esta correlação não seja observada.

A lógica para utilizarmos este instrumento se deve ao fato de que o endividamento dos países emergentes possui um movimento similar tendo se elevado de 1996 a 2002 e reduzido de 2002 a 2008, sendo que a partir de 2009, após a crise mundial financeira, se retomou a tendência de alta no endividamento, como é possível observar na Figura 3. Esse comportamento nos leva a acreditar que exista uma boa relação entre o instrumento e a variável

\footnotetext{
${ }^{48}$ Para criarmos estas variáveis dummies utilizamos a base de dados com informações dos três tipos de crises de Laeven e Valencia (2018) com dados de 1970 a 2017.

${ }^{49}$ Para todas as variáveis utilizadas foram realizados testes de raiz unitária e para todas as variáveis rejeitamos a hipótese de presença de raiz unitária em nossos dados.

${ }^{50}$ Gostaríamos de testar o instrumento utilizado por Panizza e Presbitero (2014), entretanto devido à falta de dados disponíveis para países emergentes para a construção do instrumento, ficaremos, apenas, com este instrumento apresentado, dado que o outro instrumento utilizado na literatura, a dívida defasada, apresenta uma elevadíssima taxa de persistência, por ser uma variável de estoque e acaba não sendo um instrumento útil.
} 
instrumentalizada. Além disso, há uma elevada variação no instrumento ao longo do tempo, apesar de que conforme aumenta o número de países na amostra, há uma redução na variação do instrumento entre países, além desta variação não se mostrar elevada.

Para garantirmos que nosso instrumento não possui correlação com o termo de erro de erro e nosso problema de causalidade é resolvido, temos que:

1. Esse instrumento tem como vantagem não possuir um efeito causal direto sobre o crescimento econômico, se assumirmos que não há uma forte relação entre endividamento dos outros países emergentes e o crescimento econômico do país específico;

2. Como apresentado em Panizza e Presbitero (2014), esta não influência do endividamento dos outros países emergentes sobre o crescimento econômico do país específico pode ser problemático na presença de choques globais e transbordamentos financeiros e reais. Para mitigarmos estes problemas, colocamos como variáveis de controle no nosso modelo o crescimento global e dummies para as crises cambiais, bancárias e soberanas dos países;

3. As variáveis explicativas e os instrumentos são defasados em um período para o crescimento anual e cinco períodos para o crescimento acumulado de 5 anos, reduzindo, assim, o problema de causalidade reversa existente.

Por fim, para garantirmos que o instrumento possui relação com a variável que está sendo instrumentalizada, apresentaremos uma série de testes de subidentificação e de instrumento fraco para garantirmos que nosso instrumento é relevante.

Portanto, nesta seção, apresentamos a metodologia e a base de dados que utilizaremos neste trabalho, além de mostrarmos o problema de causalidade reversa existente entre crescimento econômico e endividamento, e como buscaremos minimizar este problema via utilização de variáveis instrumentais em nosso modelo de regressão. 


\subsection{Resultados}

Após termos apresentado a metodologia e a base de dados que utilizamos neste trabalho, nesta seção apresentaremos os resultados das regressões realizadas, focando, primeiramente, nos resultados em que $k=1$, logo a taxa de crescimento é de apenas um ano e, posteriormente, quando $k=5$, portanto quando temos o crescimento acumulado de 5 anos.

\subsubsection{Crescimento anual}

Para o resultado do crescimento anual, primeiramente, apresentaremos a regressão com painel em efeitos fixos utilizando uma estrutura $A R$ (1) no termo de erro para lidar com um possível problema de persistência no termo de erro ${ }^{51}$.

\footnotetext{
${ }^{51}$ Assim como no artigo anterior, colocamos o coeficiente AR (1) no termo de erro para lidarmos com algum problema de endogeneidade existente ao trabalharmos com as variáveis defasadas no nosso modelo. É importante notar que na regressão em que o termo não é adicionado, os resultados principais se mantiveram.
} 
Tabela 21: Estimação da taxa de crescimento para o ano seguinte por efeitos fixos

\begin{tabular}{|c|c|c|}
\hline Variáveis & Estimação I & Estimação II \\
\hline Dívida & $\begin{array}{c}-0,0121965 \\
(0,139306)\end{array}$ & $\begin{array}{c}0,0125392 \\
(0,0338864)\end{array}$ \\
\hline Dívida ao quadrado & & $\begin{array}{l}-0,0002394 \\
(0,0002988)\end{array}$ \\
\hline Ln (PIB Per Capita em PPP) & $\begin{array}{c}-6,244069^{\star \star *} \\
(1,338204)\end{array}$ & $\begin{array}{c}-6,310873^{* * *} \\
(1,339231)\end{array}$ \\
\hline Investimento & $\begin{array}{c}-0,0021341 \\
(0,0364189)\end{array}$ & $\begin{array}{l}-0,0002231 \\
(0,036359)\end{array}$ \\
\hline Crescimento Populacional & $\begin{array}{c}-0,3989204^{* * *} \\
(0,0850883)\end{array}$ & $\begin{array}{c}-0,3983735^{\star * *} \\
(0,0851081)\end{array}$ \\
\hline Resultado Primário & $\begin{array}{l}0,0883737^{\star *} \\
(0,0417295)\end{array}$ & $\begin{array}{l}0,0909842^{\star *} \\
(0,0417815)\end{array}$ \\
\hline Abertura Comercial & $\begin{array}{c}0,0104872 \\
(0,0121683)\end{array}$ & $\begin{array}{c}0,0107568 \\
(0,0121317)\end{array}$ \\
\hline Inflação & $\begin{array}{c}-0,0352411^{* *} \\
(0,0176689)\end{array}$ & $\begin{array}{l}-0,0343008^{\star} \\
(0,0176582)\end{array}$ \\
\hline Crise bancária & $\begin{array}{c}0,6165977 \\
(0,8632782)\end{array}$ & $\begin{array}{c}0,6353811 \\
(0,8659831)\end{array}$ \\
\hline Crise Cambial & $\begin{array}{c}-3,434474^{\star * *} \\
(0,7299605)\end{array}$ & $\begin{array}{c}-3,454800^{* * *} \\
(0,7311978)\end{array}$ \\
\hline Crise de Dívida Soberana & $\begin{array}{c}-4,494311^{\star * *} \\
(1,560341)\end{array}$ & $\begin{array}{c}-4,540148^{\star * *} \\
(1,563961)\end{array}$ \\
\hline Crescimento Global & $\begin{array}{c}1,023722^{\star *} \\
(0,4646455)\end{array}$ & $\begin{array}{c}1,020304^{* \star} \\
(0,4654444)\end{array}$ \\
\hline Constante & $\begin{array}{c}59,68735^{\star * *} \\
(9,67012)\end{array}$ & $\begin{array}{c}59,75696^{\star * *} \\
(9,689074)\end{array}$ \\
\hline Dummies de Ano & Sim & Sim \\
\hline Coeficiente AR(1) & 0,26381392 & 0,25995519 \\
\hline Número de Observações & 691 & 691 \\
\hline$R^{2}$ & 0,2845 & 0,2807 \\
\hline Teste F & 12,09 & 11,79 \\
\hline
\end{tabular}

Fonte: Elaboração própria

Nota: Os valores com $\left(^{*}\right)$ indicam que rejeitamos a hipótese nula a $10 \%$, valores com ${ }^{* *}$ ) indicam que rejeitamos a hipótese nula a $5 \%$, valores com $\left(^{* * *}\right)$ indicam que rejeitamos a hipótese nula a 1\%. Erro-padrão em ().

Como é possível observar pela estimação I, o coeficiente de dívida apresenta o sinal negativo, assim como outros trabalhos já tinham apontado. Entretanto, seu valor não é estatisticamente significante, logo, por este modelo, o endividamento não apresenta efeito sobre a taxa de crescimento.

$\mathrm{Na}$ estimação II, buscamos verificar se a relação apresenta uma não linearidade e, assim como em outros trabalhos, apresenta o $U$ invertido, com os sinais obtidos para a dívida no nível positiva e dívida ao quadrado negativa. 
Porém, assim como na estimação I, seus coeficientes não são estatisticamente significantes.

Portanto, utilizando a metodologia de painel de efeitos fixos, não encontramos evidências de que o endividamento bruto possui efeito sobre o nível de crescimento dos países, tanto de forma linear quanto de forma não linear.

Entretanto, como apontado anteriormente, a estimação acima apresenta o problema de causalidade reversa entre taxa de crescimento e endividamento bruto. Para lidar com este problema, faremos uso da metodologia de variáveis instrumentais, utilizando como instrumento a média do endividamento bruto dos países no período t, excluindo o país i.

Abaixo, apresentamos as estimações por meio da metodologia de variáveis instrumentais por GMM: 
Tabela 22: Estimação da taxa de crescimento para o ano seguinte por variáveis instrumentais via GMM

\begin{tabular}{|c|c|c|}
\hline Variáveis & Estimação III & Estimação IV \\
\hline Dívida & $\begin{array}{c}-0,0266104^{\star \star \star} \\
(0,0069679)\end{array}$ & $\begin{array}{l}0,1555571^{* *} \\
(0.0640455)\end{array}$ \\
\hline Dívida ao quadrado & & $\begin{array}{r}-0,001755^{\star * \star} \\
(0,0006433)\end{array}$ \\
\hline Ln (PIB Per Capita em PPP) & $\begin{array}{r}-1,820362^{* * *} \\
(0,2425176)\end{array}$ & $\begin{array}{r}-1,238707^{* * *} \\
(0,3143729)\end{array}$ \\
\hline Investimento & $\begin{array}{c}0,0816844^{* \star *} \\
(0,0193875)\end{array}$ & $\begin{array}{r}0,1043433^{* * *} \\
(0,0219917)\end{array}$ \\
\hline Crescimento Populacional & $\begin{array}{c}-0,6646625^{\star * *} \\
(0,0662731)\end{array}$ & $\begin{array}{c}-0,6058042^{* * *} \\
(0,0768022)\end{array}$ \\
\hline Resultado Primário & $\begin{array}{c}0,0555173 \\
(0,0341399)\end{array}$ & $\begin{array}{l}0,089174^{* *} \\
(0,0396265)\end{array}$ \\
\hline Abertura Comercial & $\begin{array}{r}0,0109571^{* * *} \\
(0,0036907)\end{array}$ & $\begin{array}{c}0,062113 \\
(0,0044151)\end{array}$ \\
\hline Inflação & $\begin{array}{l}-0,0038255 \\
(0,0091416)\end{array}$ & $\begin{array}{l}0,292963^{*} \\
(0,016529)\end{array}$ \\
\hline Crise bancária & $\begin{array}{l}-0,6827049 \\
(1,023379)\end{array}$ & $\begin{array}{l}-0,1553582 \\
(1,155467)\end{array}$ \\
\hline Crise Cambial & $\begin{array}{l}-5,15097^{\star * *} \\
(0,7873031)\end{array}$ & $\begin{array}{c}-5,305477^{* * *} \\
(0,882852)\end{array}$ \\
\hline Crise de Dívida Soberana & $\begin{array}{c}-4,388653^{* * *} \\
(1,395605)\end{array}$ & $\begin{array}{c}-4,864754^{\star \star *} \\
(1,571717)\end{array}$ \\
\hline Crescimento Global & $\begin{array}{l}27,89647^{\star *} \\
(12,12844)\end{array}$ & $\begin{array}{l}33,22165^{\star \star} \\
(13,72091)\end{array}$ \\
\hline Constante & $\begin{array}{c}-137,3202^{* *} \\
(69,44209) \\
\end{array}$ & $\begin{array}{l}-177,541^{* *} \\
(79,0595)\end{array}$ \\
\hline Dummies de Ano & $\operatorname{Sim}$ & $\operatorname{Sim}$ \\
\hline Número de Observações & 727 & 727 \\
\hline$R^{2}$ Centrado & 0,4769 & 0,3463 \\
\hline Teste F & 17,10 & 13,35 \\
\hline P-valor do Anderson LM estat. & 0,0000 & 0,0000 \\
\hline $\begin{array}{c}\text { P-valor Sanderson-Windmeijer F } \\
\text { teste }\end{array}$ & 0,0000 & 0,0000 \\
\hline Cragg-Donald F estat. & 2370,7 & 30,58 \\
\hline
\end{tabular}

Fonte: Elaboração própria

Nota: Os valores com $\left({ }^{*}\right)$ indicam que rejeitamos a hipótese nula a 10\%, valores com $\left(^{* *}\right)$ indicam que rejeitamos a hipótese nula a $5 \%$, valores com $\left(^{* * *}\right)$ indicam que rejeitamos a hipótese nula a 1\%. Erro-padrão em ().

A estimação III, assim como a estimação I, aponta que há um efeito negativo do endividamento sobre o crescimento econômico. Entretanto, ao contrário da estimação anterior, este efeito é estatisticamente significante. Portanto, este resultado corrobora os resultados encontrados na literatura para países emergentes, ainda que estes resultados utilizassem a dívida externa ao invés da dívida interna bruta, como fazemos neste trabalho. 
Para testarmos a qualidade do nosso instrumento, realizamos uma série de testes de subidentificação e de instrumentos fracos. O p-valor da estatística LM de Anderson ${ }^{52}$ e o $\mathrm{p}$-valor do teste $\mathrm{F}$ de Sanderson-Windmeijer ${ }^{53}$ do primeiro estágio nos levam a rejeitar a hipótese nula de subidentificação do instrumento. Entretanto, o teste de subidentificação não é suficiente para dizer se um instrumento é ou não fracamente exógeno. Para isso, utilizamos o teste de Cragg-Donald para instrumento fraco, e este nos leva a rejeitar a hipótese de que o estimador é fracamente identificado, indicando, portanto, a ausência de problemas de instrumento fraco. O valor do $\mathrm{F}$ do teste é significativamente superior ao dos valores críticos desenvolvidos por Stock e Yogo (2005) de 16,38 para um viés máximo de $10 \%$.

Para a estimação IV, verificamos que a hipótese de não linearidade é estatisticamente significante, isto é, tanto a dívida linear quanto a quadrática são estatisticamente significantes. Além disso, esta não linearidade entre taxa de crescimento e endividamento bruto apresenta o formato de um $U$ invertido, em que o nível máximo de endividamento que estimularia o crescimento seria em torno de $44 \%$ do PIB, sendo significativamente inferior aos resultados obtidos para países desenvolvidos que se encontram em valores entre 70-100\% do PIB em diversos estudos que observaram a não-linearidade. Outro ponto interessante é que nossas variáveis de controle apresentaram os sinais esperados pela teoria econômica, com logaritmo do PIB per capita, crescimento populacional e crises cambiais e soberanas tendo efeitos negativos sobre crescimento, enquanto crescimento, resultado primário, inflação e crescimento global tendo efeito negativo, abertura comercial e crise bancária não tiveram efeito estatisticamente significantes.

Assim como no caso anterior, observamos que os testes para a validade dos instrumentos utilizados indicam que rejeitamos a hipótese nula de subidentificação dos instrumentos, e encontramos evidências da ausência de problemas de instrumento fraco dado o elevado valor do teste F de Cragg-

\footnotetext{
${ }^{52}$ Este é o teste canônico de correlação de Anderson (1951).

${ }^{53}$ Este teste foi desenvolvido por Sanderson e Windmeijer (2016) que é um aperfeiçoamento do teste desenvolvido por Angrist e Pischke (2008) para testar a subidentificação do modelo.
} 
Donald, acima do valor crítico de 7,03 para um viés máximo de $10 \%$ segundo Stock e Yogo (2005).

Para adicionarmos maior robustez aos resultados obtidos, abaixo faremos as estimações que levam em consideração problemas de heterocedasticidade e autocorrelação, além da estimação por meio de variáveis instrumentais em um painel de efeitos fixos que também controlam para heterocedasticidade e autocorrelação: 
Tabela 23: Estimação da taxa de crescimento para o ano seguinte por variáveis instrumentais via GMM

\begin{tabular}{|c|c|c|}
\hline Variáveis & Estimação V & Estimação VI \\
\hline Dívida & $\begin{array}{l}0,1555571^{*} \\
(0,0865074)\end{array}$ & $\begin{array}{c}0,140094^{*} \\
(0,0769827)\end{array}$ \\
\hline Dívida ao quadrado & $\begin{array}{l}-0,001755^{\star *} \\
(0,0008855)\end{array}$ & $\begin{array}{r}-0,0012406^{*} \\
(0,000744)\end{array}$ \\
\hline Ln (PIB Per Capita em PPP) & $\begin{array}{l}-1,238707^{\star * *} \\
(0,4268679)\end{array}$ & $\begin{array}{c}-3,956933^{\star * *} \\
(1,132314)\end{array}$ \\
\hline Investimento & $\begin{array}{c}0,1043433^{* * *} \\
(0,0312081)\end{array}$ & $\begin{array}{l}0,0975538^{*} \\
(0,0505008)\end{array}$ \\
\hline Crescimento Populacional & $\begin{array}{c}-0,6058042^{\star \star \star} \\
(0,1395217)\end{array}$ & $\begin{array}{l}-0,5228682^{\star *} \\
(0,2103691)\end{array}$ \\
\hline Resultado Primário & $\begin{array}{l}0,089174^{* *} \\
(0,0437131)\end{array}$ & $\begin{array}{c}0,0575788 \\
(0,0449686)\end{array}$ \\
\hline Abertura Comercial & $\begin{array}{c}0,062113 \\
(0,0054874)\end{array}$ & $\begin{array}{l}0,265144^{\star *} \\
(0,0111967)\end{array}$ \\
\hline Inflação & $\begin{array}{c}0,292963 \\
(0,0210484)\end{array}$ & $\begin{array}{l}-0,0001443 \\
(0,0214266)\end{array}$ \\
\hline Crise bancária & $\begin{array}{c}-0,1553582 \\
(0,96849)\end{array}$ & $\begin{array}{c}-0,3626048 \\
(1,011778)\end{array}$ \\
\hline Crise Cambial & $\begin{array}{c}-5,305477^{* * *} \\
(1,297863)\end{array}$ & $\begin{array}{c}-5,081817^{* \star *} \\
(1,20845)\end{array}$ \\
\hline Crise de Dívida Soberana & $\begin{array}{c}-4,864754^{\star *} \\
(2,35523)\end{array}$ & $\begin{array}{l}-4,748286^{\star} \\
(2,526982)\end{array}$ \\
\hline Crescimento Global & $\begin{array}{r}33,22165^{\star \star \star} \\
(10,07618)\end{array}$ & $\begin{array}{c}13,67373 \\
(10,84711)\end{array}$ \\
\hline Constante & $\begin{array}{l}-177,541^{* * *} \\
(59,50683)\end{array}$ & \\
\hline Dummies de Ano & Sim & Sim \\
\hline Número de Observações & 727 & 727 \\
\hline$R^{2}$ Centrado & 0,3463 & 0,4157 \\
\hline Teste F & 7,39 & 12,80 \\
\hline $\begin{array}{c}\text { P-valor do Kleibergen-Paap LM } \\
\text { estat. }\end{array}$ & 0,0000 & 0,0000 \\
\hline $\begin{array}{c}\text { P-valor Sanderson-Windmeijer F } \\
\text { teste }\end{array}$ & 0,0000 & 0,0000 \\
\hline Kleibergen-Paap Wald F estat. & 7,21 & 12,89 \\
\hline
\end{tabular}

Fonte: Elaboração própria

Nota: Os valores com $\left({ }^{*}\right)$ indicam que rejeitamos a hipótese nula a 10\%, valores com $\left(^{* *}\right)$ indicam que rejeitamos a hipótese nula a $5 \%$, valores com $\left.{ }^{* \star *}\right)$ indicam que rejeitamos a hipótese nula a 1\%. Erro-padrão em ().

$\mathrm{Na}$ estimação $\mathrm{V}$ tratamos para possíveis problemas de heterocedasiticidade, utilizando a metodologia robusta, e de autocorrelação, utilizando o bandwidth igual a 3, dado que a regra de bolso é que seu tamanho deve ser equivalente a $T^{\frac{1}{3}}$. Apesar da significância ter se reduzido ao tratarmos 
para estes problemas, o resultado ainda se mantém, apontando a não linearidade entre crescimento econômico e endividamento bruto.

Para verificarmos a qualidade do nosso instrumento, continuamos utilizando testes de subindetificação e de instrumentos fracos. Para os testes de subidentificação, continuamos rejeitando a hipótese nula, e a diferença é que como nosso modelo leva em consideração heterocedasticidade e autocorrelação, a estatística adequada para tratar este problema é o teste LM de Kleibergen-Paap ${ }^{54}$. No teste que verifica se o instrumento é fraco, devido a levarmos em consideração a heterocedasticidade e a autocorrelação, o teste adequado é o de Kleibergen-Paap Wald $F$ teste que possui um valor de 7,21, que é abaixo do valor definido como mais adequado por Staiger e Stock (1997) que indica que teria que ser acima de 10. Entretanto, quando observamos os valores críticos de Stock e Yogo (2005), para um viés máximo de 10\%, o valor crítico indicado é de 7,03. Portanto, podemos rejeitar a hipótese que nosso instrumento é fraco.

Na estimação VI, levamos em consideração os problemas anteriores de heterocedasticidade e autocorrelação, além de fazer a regressão por meio da metodologia de painel de efeitos fixos com variáveis instrumentais via GMM. Como esta é a metodologia mais robusta utilizada neste trabalho, consideramos ser este o principal resultado obtido. Por este método, corroboramos os resultados anteriores encontrando uma não linearidade entre taxa de crescimento econômico e endividamento bruto, sendo que o ponto de máximo do efeito da dívida sobre o crescimento se dá em torno de um endividamento de $56 \%$ do $\mathrm{PIB}^{55}$. Para as variáveis de controle, continuamos observando resultados de acordo com o esperado pela teoria econômica.

Com relação à validade dos instrumentos utilizados, observamos que rejeitamos os testes de subidentificação dos instrumentos e para o teste de

\footnotetext{
${ }^{54}$ Este teste foi desenvolvido por Kleibergen e Paap (2006).

55 Para darmos maior robustez aos resultados obtidos, fizemos as mesmas estimações anteriores, mas alterando a taxa de crescimento do país para o crescimento do PIB per capita real em moeda nacional. Os resultados, que não foram apresentados neste ensaio, mostram que a hipótese de não linearidade continua sendo satisfeita e o ponto máximo continua em torno de $40-60 \%$ do PIB para o endividamento.
} 
instrumento fraco, a estatística de Kleibergen-Paap Wald $\mathrm{F}$ teste possui valor de 12,9, acima de 10, definido como mais adequado por Staiger e Stock (1997) e acima do valor crítico de viés máximo de $10 \%$ de Stock e Yogo (2005), que é de 7,03. Portanto, rejeitamos a hipótese que nosso instrumento é fraco.

Apesar de não reportamos os resultados neste trabalho, a regressão realizada no primeiro estágio mostrou que os instrumentos se mostraram muito significantes tanto para a variável endividamento quanto para a variável endividamento ao quadrado para todas as regressões por meio de variáveis instrumentais para o crescimento de um ano.

No Anexo B.2 fizemos estes mesmos procedimentos para o endividamento externo, soma do público com o privado, e observamos que os resultados não são estatisticamente significantes.

\subsubsection{Crescimento de cinco anos}

Tendo apresentado os resultados para o crescimento anual, repetiremos os procedimentos para o crescimento de 5 anos para verificarmos se é válida, também, a hipótese de não linearidade entre crescimento econômico e endividamento bruto.

Primeiramente, apresentaremos a regressão com painel em efeitos fixos utilizando uma estrutura AR (1) no termo de erro: 
Tabela 24: Estimação da taxa de crescimento para cinco anos por efeitos fixos

\begin{tabular}{|c|c|c|}
\hline Variáveis & Estimação VI & Estimação VIII \\
\hline Dívida & $\begin{array}{c}-0,0632267^{\star \star *} \\
(0,0228849)\end{array}$ & $\begin{array}{c}0,0598751 \\
(0,0636367)\end{array}$ \\
\hline Dívida ao quadrado & & $\begin{array}{r}-0,0007374^{* *} \\
(0,0003559)\end{array}$ \\
\hline Ln (PIB Per Capita em PPP) & $\begin{array}{c}-40,56699^{* * *} \\
(5,395949)\end{array}$ & $\begin{array}{c}-38,76265^{\star * *} \\
(5,444504)\end{array}$ \\
\hline Investimento & $\begin{array}{c}0,1480078^{* * *} \\
(0,0555063)\end{array}$ & $\begin{array}{l}0,1377047^{\star *} \\
(0,0555301)\end{array}$ \\
\hline Crescimento Populacional & $\begin{array}{c}-0,4410689^{\star * *} \\
(0,098161)\end{array}$ & $\begin{array}{c}-0,4286633^{\star \star *} \\
(0,0979897)\end{array}$ \\
\hline Resultado Primário & $\begin{array}{l}0,1317079^{\star *} \\
(0,0566374)\end{array}$ & $\begin{array}{l}0,1452283^{\star *} \\
(0,0568077)\end{array}$ \\
\hline Abertura Comercial & $\begin{array}{c}0,0022413 \\
(0,0254995)\end{array}$ & $\begin{array}{c}-0,0015144 \\
(0,0254693)\end{array}$ \\
\hline Inflação & $\begin{array}{l}-0,0167431 \\
(0,0167808)\end{array}$ & $\begin{array}{c}-0,017628 \\
(0,0167283)\end{array}$ \\
\hline Crise bancária & $\begin{array}{l}-2,006606^{\star * *} \\
(0,8226095)\end{array}$ & $\begin{array}{l}-2,051768^{\star *} \\
(0,8199368)\end{array}$ \\
\hline Crise Cambial & $\begin{array}{l}-2,38065^{\star \star \star} \\
(0,7700891)\end{array}$ & $\begin{array}{l}-2,179552^{\star \star *} \\
(0,7734924)\end{array}$ \\
\hline Crise de Dívida Soberana & $\begin{array}{l}-2,4524^{\star \star \star} \\
(1,214847)\end{array}$ & $\begin{array}{c}-2,924594^{\star *} \\
(1,231794)\end{array}$ \\
\hline Crescimento Global & $\begin{array}{c}1,437448^{*} \\
(0,8133397)\end{array}$ & $\begin{array}{c}1,348299^{*} \\
(0,8133751)\end{array}$ \\
\hline Constante & $\begin{array}{c}378,3021^{* * *} \\
(4,253951)\end{array}$ & $\begin{array}{c}360,0643^{\star * *} \\
(4,312722)\end{array}$ \\
\hline Dummies de Ano & Sim & Sim \\
\hline Coeficiente $A R(1)$ & 0,91838102 & 0,91803331 \\
\hline Número de Observações & 548 & 548 \\
\hline$R^{2}$ & 0,2206 & 0,2366 \\
\hline Teste F & 16,06 & 15,80 \\
\hline
\end{tabular}

Fonte: Elaboração própria

Nota: Os valores com $\left(^{*}\right)$ indicam que rejeitamos a hipótese nula a 10\%, valores com $\left(^{* *}\right)$ indicam que rejeitamos a hipótese nula a $5 \%$, valores com $\left(^{* * *}\right)$ indicam que rejeitamos a hipótese nula a 1\%. Erro-padrão em ().

Ao contrário do que observamos no crescimento anual, para o caso linear encontramos uma relação negativa e estatisticamente significante entre crescimento e endividamento. Já para a verificação de não linearidade, ainda que os coeficientes em nível e quadrático apresentem os sinais de acordo com a relação de máximo, apenas a variável ao quadrado se mostra estatisticamente significante. 
Portanto, apesar de apresentar resultados melhores que o do crescimento anual com o efeito negativo do endividamento sobre o crescimento, para a estimação sem variáveis instrumentais não encontramos a relação de não linearidade. Abaixo, apresentamos as regressões com variável instrumental para o efeito linear e não linear do endividamento sobre o crescimento:

Tabela 25: Estimação da taxa de crescimento para cinco anos por variáveis instrumentais via GMM

\begin{tabular}{|c|c|c|}
\hline Variáveis & Estimação IX & Estimação X \\
\hline Dívida & $\begin{array}{c}-0,2410503^{\star \star \star} \\
(0,0326893)\end{array}$ & $\begin{array}{l}1,026128^{\star * *} \\
(0,3317331)\end{array}$ \\
\hline Dívida ao quadrado & & $\begin{array}{r}-0,0120846^{\star \star \star} \\
(0,0033085)\end{array}$ \\
\hline Ln (PIB Per Capita em PPP) & $\begin{array}{l}-11,30015^{\star \star *} \\
(1,083746)\end{array}$ & $\begin{array}{c}-7,555005^{\star * *} \\
(1,562767)\end{array}$ \\
\hline Investimento & $\begin{array}{c}0,6887524^{\star \star *} \\
(0,0928289)\end{array}$ & $\begin{array}{l}0,8452509^{* * *} \\
(0,119275)\end{array}$ \\
\hline Crescimento Populacional & $\begin{array}{l}-2,92151^{\star * *} \\
(0,2962959)\end{array}$ & $\begin{array}{l}-2,608604^{\star * *} \\
(0,3856037)\end{array}$ \\
\hline Resultado Primário & $\begin{array}{c}0,2174872 \\
(0,1590267)\end{array}$ & $\begin{array}{l}0,5156223^{\star \star} \\
(0,2163143)\end{array}$ \\
\hline Abertura Comercial & $\begin{array}{c}0,046541^{* \star \star} \\
(0,017325)\end{array}$ & $\begin{array}{l}0,0091517 \\
(0,240282)\end{array}$ \\
\hline Inflação & $\begin{array}{l}0,0589116 \\
(0,0404737)\end{array}$ & $\begin{array}{c}0,2821226^{\star \star *} \\
(0,0842899)\end{array}$ \\
\hline Crise bancária & $\begin{array}{c}-4,899533^{\star *} \\
(2,279292)\end{array}$ & $\begin{array}{l}-2,979264 \\
(2,914168)\end{array}$ \\
\hline Crise Cambial & $\begin{array}{l}-9,439273^{* * *} \\
(2,181016)\end{array}$ & $\begin{array}{c}-7,056863^{* \star *} \\
(2,835866)\end{array}$ \\
\hline Crise de Dívida Soberana & $\begin{array}{l}-4,117534^{\star \star \star} \\
(3,429202)\end{array}$ & $\begin{array}{c}-7,451674^{\star \star \star} \\
(4,467272)\end{array}$ \\
\hline Crescimento Global & $\begin{array}{c}0,4121725 \\
(0,5223193)\end{array}$ & $\begin{array}{c}0,667238 \\
(0,6694596)\end{array}$ \\
\hline Constante & $\begin{array}{c}112,6586^{\star * *} \\
(20,25923)\end{array}$ & $\begin{array}{c}40,39338 \\
(30,69463) \\
\end{array}$ \\
\hline Dummies de Ano & Sim & $\operatorname{Sim}$ \\
\hline Número de Observações & 584 & 584 \\
\hline$R^{2}$ Centrado & 0,5114 & 0,2115 \\
\hline Teste F & 17,91 & 10,79 \\
\hline P-valor do Anderson LM estat. & 0,0000 & 0,0000 \\
\hline $\begin{array}{c}\text { P-valor Sanderson-Windmeijer F } \\
\text { teste }\end{array}$ & 0,0000 & 0,0000 \\
\hline Cragg-Donald F estat. & 1681,9 & 22,62 \\
\hline
\end{tabular}


Nas estimações com variáveis instrumentais, corroboramos o resultado sem variáveis instrumentais em que o endividamento possui um efeito negativo e estatisticamente significante sobre o crescimento.

$\mathrm{Na}$ estimação $X$ verificamos que, assim como no caso do crescimento anual, encontramos evidências de não linearidade, sendo que o ponto de máximo se encontra em um endividamento de $42,5 \%$ do PIB, muito similar ao observado para o crescimento anual; além disso a maioria das variáveis de controle apresentaram significância e o sinal esperado pela teoria.

Por fim, todos as estatísticas mostram que os instrumentos utilizados não sofrem com os problemas de subidentificação ou de instrumento fraco.

Assim como no crescimento anual, adicionamos mais robustez aos nossos resultados de crescimento de 5 anos aos fazermos a regressão robusta para heterocedasticidade e autocorrelação, além da regressão com dados em painel com efeitos fixos utilizando variáveis instrumentais, controlando para heterocedasticidade e autocorrelação. 
Tabela 26: Estimação da taxa de crescimento para cinco anos por variáveis instrumentais via GMM

\begin{tabular}{|c|c|c|}
\hline Variáveis & Estimação XI & Estimação XII \\
\hline Dívida & $\begin{array}{l}1,026128^{\star \star} \\
(0,4568891)\end{array}$ & $\begin{array}{l}0,886259^{\star * \star} \\
(0,2728415)\end{array}$ \\
\hline Dívida ao quadrado & $\begin{array}{c}-0,0120846^{\star \star \star} \\
(0,0046075)\end{array}$ & $\begin{array}{r}-0,0084224^{* * *} \\
(0,0025711)\end{array}$ \\
\hline Ln (PIB Per Capita em PPP) & $\begin{array}{c}-7,555005^{\star * \star} \\
(2,383202)\end{array}$ & $\begin{array}{l}-7,591564 \\
(9,812066)\end{array}$ \\
\hline Investimento & $\begin{array}{c}0,8452509^{* * *} \\
(0,2547918)\end{array}$ & $\begin{array}{c}0,8466605^{\star \star *} \\
(0,2734465)\end{array}$ \\
\hline Crescimento Populacional & $\begin{array}{l}-2,608604^{\star * *} \\
(0,5230965)\end{array}$ & $\begin{array}{c}-1,230586^{\star * *} \\
(0,3602593)\end{array}$ \\
\hline Resultado Primário & $\begin{array}{c}0,5456223 \\
(0,3608005)\end{array}$ & $\begin{array}{c}0,100682 \\
(0,2998299)\end{array}$ \\
\hline Abertura Comercial & $\begin{array}{c}0,0091517 \\
(0,0326927)\end{array}$ & $\begin{array}{c}0,0364737 \\
(0,0639501)\end{array}$ \\
\hline Inflação & $\begin{array}{c}0,2821226^{\star * *} \\
(0,0976137)\end{array}$ & $\begin{array}{l}0,1389091^{* *} \\
(0,0699391)\end{array}$ \\
\hline Crise bancária & $\begin{array}{l}-2,979264 \\
(3,866891)\end{array}$ & $\begin{array}{c}-5,604341^{* *} \\
(2,278300)\end{array}$ \\
\hline Crise Cambial & $\begin{array}{l}-7,056863 \\
(4,61606)\end{array}$ & $\begin{array}{c}-9,962435^{* * *} \\
(2,479475)\end{array}$ \\
\hline Crise de Dívida Soberana & $\begin{array}{l}-7,451674 \\
(4,699835)\end{array}$ & $\begin{array}{l}-9,057912^{*} \\
(5,020694)\end{array}$ \\
\hline Crescimento Global & $\begin{array}{c}0,667238 \\
(0,6757814)\end{array}$ & $\begin{array}{c}0,5324041 \\
(0,8171964)\end{array}$ \\
\hline Constante & $\begin{array}{c}40,39338 \\
(37,32697) \\
\end{array}$ & \\
\hline Dummies de Ano & Sim & Sim \\
\hline Número de Observações & 584 & 584 \\
\hline$R^{2}$ Centrado & 0,2115 & 0,4128 \\
\hline Teste $\mathrm{F}$ & 5,61 & 8,79 \\
\hline $\begin{array}{c}\text { P-valor do Kleibergen-Paap LM } \\
\text { estat. }\end{array}$ & 0,0000 & 0,0000 \\
\hline $\begin{array}{l}\text { P-valor Sanderson-Windmeijer F } \\
\text { teste }\end{array}$ & 0,0000 & 0,0000 \\
\hline Kleibergen-Paap Wald F estat. & 7,00 & 10,25 \\
\hline
\end{tabular}

Fonte: Elaboração própria

Nota: Os valores com $\left({ }^{*}\right)$ indicam que rejeitamos a hipótese nula a 10\%, valores com $\left(^{* *}\right)$ indicam que rejeitamos a hipótese nula a $5 \%$, valores com $\left(^{* * *}\right)$ indicam que rejeitamos a hipótese nula a 1\%. Erro-padrão em ().

Para a regressão $\mathrm{XI}$, robusta para a heterocedasticidade $\mathrm{e}$ autocorrelação, observamos que a hipótese de não linearidade entre crescimento e endividamento se mantem, com resultados ainda mais estatisticamente significantes para a variável linear e ao quadrado. Além disso, apesar do valor do teste K-P Wald F estar abaixo de 10, ele está em linha com 
o valor crítico de viés máximo de $10 \%$ de Stock e Yogo (2005) que é de 7,03, nos levando a rejeitar a hipótese que nosso instrumento é fraco.

Por fim, para a regressão XII com painel em efeitos fixos com variáveis instrumentais, a hipótese de não linearidade é confirmada, sendo que o valor máximo do endividamento sobre o crescimento fica em torno $53 \%$ do PIB $^{56}$. Já os testes para a validade dos instrumentos, todos os testes apontam que nosso instrumento não está subidentificado e rejeitamos a hipótese de que nosso instrumento é fraco.

Assim como fizemos para o crescimento de um ano, as regressões no primeiro estágio mostraram que as variáveis instrumentais foram bem significantes para explicar as variáveis endividamento e endividamento ao quadrado.

\subsubsection{Possíveis variáveis relevantes omitidas}

Outra variável que, potencialmente, pode afetar o efeito do endividamento público sobre o crescimento econômico é a democracia. Sua utilização se deve ao trabalho de Kourtellos et al. (2013), que verificou que o endividamento possui um efeito negativo em países com baixos níveis de democracia, mas não possui efeito em países democráticos. Como variável de democracia utilizamos o índice do Polity IV57 e não encontramos significância nesta variável para o crescimento anual, mas encontramos para o crescimento de cinco anos. Entretanto, em nenhum dos casos ela alterou nossas conclusões sobre 0 efeito do endividamento sobre o crescimento econômico.

Posteriormente, além de adicionarmos a variável democracia como controle, fizemos uma interação dela com a variável de endividamento.

\footnotetext{
${ }^{56}$ Assim como no caso do crescimento anual, também fizemos as regressões utilizando como variável dependente o crescimento anual em moeda nacional e os resultados pouco se alteram, tanto em termos de significância quanto no ponto de máximo do endividamento sobre 0 crescimento.

${ }^{57}$ Esta variável mede a democracia por meio de três elementos essenciais: presença de instituições e procedimentos pelos quais os cidadãos conseguem expressar suas opções políticas e de líderes; existência de instituições que limitem o poder do líder do executivo; garantia de liberdades civis a todos os cidadãos e em atos políticos. Esse índice vai de 0 , que seria o país sem democracia alguma a 10, com total democracia.
} 
Tabela 27: Estimação com democracia

\begin{tabular}{|c|c|c|}
\hline Variáveis & Estimação 1y & Estimação $5 y$ \\
\hline Dívida & $\begin{array}{l}0,599468^{*} \\
(0,3608302)\end{array}$ & $\begin{array}{l}2,061371^{* \star *} \\
(0,7664967)\end{array}$ \\
\hline Dívida ao quadrado & $\begin{array}{c}-0,0063293^{*} \\
(0,0037998)\end{array}$ & $\begin{array}{c}-0,0201473^{* * *} \\
(0,0076983)\end{array}$ \\
\hline Dívida*Dummy Democracia & $\begin{array}{l}-0,0780792 \\
(0,0771985)\end{array}$ & $\begin{array}{l}-0,2482893^{*} \\
(0,1395856)\end{array}$ \\
\hline Dívida ao quadrado*Dummy & 0,000895 & $0,0023361^{*}$ \\
\hline Democracia & $(0,0007567)$ & $(0,0013500)$ \\
\hline Ln (PIB Per Capita em PPP) & $\begin{array}{l}-2,578491^{*} \\
(1,514831)\end{array}$ & $\begin{array}{l}-5,087477 \\
(8,588063)\end{array}$ \\
\hline Investimento & $\begin{array}{l}0,1157216^{* *} \\
(0,0569262)\end{array}$ & $\begin{array}{l}0,8815642^{* * *} \\
(0,2067714)\end{array}$ \\
\hline Crescimento Populacional & $\begin{array}{c}-0,4598019^{\star *} \\
(0,2201169)\end{array}$ & $\begin{array}{l}-1,003506^{* \star *} \\
(0,3660202)\end{array}$ \\
\hline Resultado Primário & $\begin{array}{l}0,0681507 \\
(0,062063)\end{array}$ & $\begin{array}{c}0,1272562 \\
(0,2575741)\end{array}$ \\
\hline Abertura Comercial & $\begin{array}{c}0,011576 \\
(0,0167101)\end{array}$ & $\begin{array}{c}0,0064492 \\
(0,0569797)\end{array}$ \\
\hline Inflação & $\begin{array}{c}0,0671866 \\
(0,0690556)\end{array}$ & $\begin{array}{l}0,3086038^{*} \\
(0,1602693)\end{array}$ \\
\hline Democracia & $\begin{array}{l}1,137471 \\
(1,677246)\end{array}$ & $\begin{array}{c}4,283106 \\
(3,060533)\end{array}$ \\
\hline Crise bancária & $\begin{array}{r}-0,268682 \\
(1,05886)\end{array}$ & $\begin{array}{l}-6,430145^{\star \star *} \\
(1,853215)\end{array}$ \\
\hline Crise Cambial & $\begin{array}{c}-4,858366^{\star \star \star} \\
(1,33462)\end{array}$ & $\begin{array}{c}-12,98369^{\star *} \\
(2,714193)\end{array}$ \\
\hline Crise de Dívida Soberana & $\begin{array}{l}-2,784237 \\
(2,892318)\end{array}$ & $\begin{array}{c}-3,96042 \\
(4,285991)\end{array}$ \\
\hline Crescimento Global & $\begin{array}{c}27,20859 \\
(14,13908)\end{array}$ & $\begin{array}{l}0,6762119 \\
(0,718102)\end{array}$ \\
\hline Dummies de Ano & $\operatorname{Sim}$ & $\operatorname{Sim}$ \\
\hline Número de Observações & 727 & 584 \\
\hline$R^{2}$ Centrado & 0,1263 & 0,2995 \\
\hline Teste F & 11,72 & 12,51 \\
\hline $\begin{array}{l}\text { P-valor do Kleibergen-Paap LM } \\
\text { estat. }\end{array}$ & 0,0229 & 0,0024 \\
\hline $\begin{array}{c}\text { P-valor Sanderson-Windmeijer F } \\
\text { teste }\end{array}$ & 0,0134 & 0,0000 \\
\hline Kleibergen-Paap Wald F estat. & 1,58 & 2,98 \\
\hline
\end{tabular}

Fonte: Elaboração própria

Nota: Os valores com $\left({ }^{*}\right)$ indicam que rejeitamos a hipótese nula a $10 \%$, valores com $\left({ }^{* *}\right)$ indicam que rejeitamos a hipótese nula a $5 \%$, valores com $\left(^{* * *}\right)$ indicam que rejeitamos a hipótese nula a 1\%. Erro-padrão em ().

Para o crescimento de um ano, assim como no caso anterior, não observamos significância da variável democracia e não houve alteração nos resultados apara a variável endividamento. Para o crescimento de cinco anos observamos que a democracia possui efeito na interação com o endividamento, ainda que tanto para baixos quanto altos níveis de democracia continue existindo 
um ponto de reversão, sendo esse divergente: para países com mais alto nível de democracia este ponto de reversão se situa em torno de $66 \%$ do PIB, enquanto que para países com o mais baixo nível de democracia esse ponto se situa em torno de $51 \%$ do PIB. Portanto, o nível de democracia possui algum impacto sobre a relação entre endividamento e crescimento, sendo que para níveis maiores de democracia o ponto de reversão ocorre para níveis maiores de endividamento ${ }^{58}$.

Um ponto problemático nesta regressão é o fato de que apesar de rejeitarmos a hipótese de instrumento fraco, o valor do teste de Kleibergen-Paap Wald $\mathrm{F}$ é baixo, apesar de não termos um valor crítico para comparar na tabela de Stock e Yogo (2005) para quatro variáveis instrumentadas e quatro instrumentos.

Outra variável que pode afetar o endividamento público é o endividamento privado. Em países que o endividamento privado é elevado, o efeito do endividamento público pode ser ainda maior. Entretanto, não há uma variável de endividamento privado disponível para nosso conjunto de países emergentes. Como proxy, iremos utilizar o crédito doméstico ao setor privado em \% do PIB disponível na base de dados do Banco Mundial (2019).

Abaixo, apresentamos o resultado da nossa regressão com painel de efeitos fixos via GMM com variáveis instrumentais para crescimento anual e o crescimento de cinco anos

${ }^{58}$ Este resultado está de acordo com a teoria de North e Weingast (1989) que mostram como avanços nas instituições levaram a melhorias no mercado de capitais e crescimento econômico. 
Tabela 28: Estimação com crédito privado como variável de controle

\begin{tabular}{|c|c|c|}
\hline Variáveis & Estimação 1y & Estimação 5y \\
\hline Dívida & $\begin{array}{l}0,1052409^{*} \\
(0,0595787)\end{array}$ & $\begin{array}{c}0,7882198^{* * *} \\
(0,2334851)\end{array}$ \\
\hline Dívida ao quadrado & $\begin{array}{l}-0,0008859^{*} \\
(0,0005287)\end{array}$ & $\begin{array}{r}-0,0072782^{\star \star \star *} \\
(0,0021755)\end{array}$ \\
\hline Ln (PIB Per Capita em PPP) & $\begin{array}{l}-2,928982^{\star * *} \\
(0,9224542)\end{array}$ & $\begin{array}{r}-5,307191 \\
(7,26363)\end{array}$ \\
\hline Investimento & $\begin{array}{c}0,1171857^{\star \star \star} \\
(0,0297949)\end{array}$ & $\begin{array}{c}0,9155381^{\star * \star} \\
(0,2007786)\end{array}$ \\
\hline Crescimento Populacional & $\begin{array}{c}-0,5186938^{* \star *} \\
(0,0852885)\end{array}$ & $\begin{array}{c}-1,174658^{* \star *} \\
(0,323426)\end{array}$ \\
\hline Resultado Primário & $\begin{array}{c}0,0365799 \\
(0,0378221)\end{array}$ & $\begin{array}{c}0,044815 \\
(0,2304005)\end{array}$ \\
\hline Abertura Comercial & $\begin{array}{c}0,0396555^{\star * *} \\
(0,0108656)\end{array}$ & $\begin{array}{l}0,0900471^{*} \\
(0,0526221)\end{array}$ \\
\hline Inflação & $\begin{array}{l}-0,0104433 \\
(0,0144701)\end{array}$ & $\begin{array}{c}0,0915468 \\
(0,0641539)\end{array}$ \\
\hline Crédito Privado & $\begin{array}{c}-0,0527196^{\star \star \star} \\
(0,0119853)\end{array}$ & $\begin{array}{c}-0,1862478^{* * *} \\
(0,515951)\end{array}$ \\
\hline Crise bancária & $\begin{array}{l}-0,0527196 \\
(1,056391)\end{array}$ & $\begin{array}{c}-4,679856^{\star *} \\
(1,951226)\end{array}$ \\
\hline Crise Cambial & $\begin{array}{l}-4,976686^{\star * *} \\
(0,7960783)\end{array}$ & $\begin{array}{c}-7,659197^{* * *} \\
(2,448206)\end{array}$ \\
\hline Crise de Dívida Soberana & $\begin{array}{c}-4,363043^{\star * \star} \\
(1,39945)\end{array}$ & $\begin{array}{c}-8,427426^{* *} \\
(3,6483)\end{array}$ \\
\hline Crescimento Global & $\begin{array}{c}7,284451 \\
(11,06411)\end{array}$ & $\begin{array}{c}0,284641 \\
(0,5989865)\end{array}$ \\
\hline Dummies de Ano & $\operatorname{Sim}$ & Sim \\
\hline Número de Observações & 712 & 570 \\
\hline$R^{2}$ Centrado & 0,4443 & 0,4448 \\
\hline Teste F & 12,05 & 13,82 \\
\hline $\begin{array}{c}\text { P-valor do Kleibergen-Paap LM } \\
\text { estat. }\end{array}$ & 0,0000 & 0,0000 \\
\hline $\begin{array}{c}\text { P-valor Sanderson-Windmeijer F } \\
\text { teste }\end{array}$ & 0,0000 & 0,0000 \\
\hline Kleibergen-Paap Wald F estat. & 12,57 & 12,71 \\
\hline
\end{tabular}

Fonte: Elaboração própria

Nota: Os valores com $\left({ }^{\star}\right)$ indicam que rejeitamos a hipótese nula a 10\%, valores com $\left(^{* \star}\right)$ indicam que rejeitamos a hipótese nula a $5 \%$, valores com $\left(^{* * *}\right)$ indicam que rejeitamos a hipótese nula a 1\%. Erro-padrão em ().

O crédito privado se mostrou uma variável estatisticamente significante que possui um efeito negativo sobre a taxa de crescimento econômico, mas não alterou a não linearidade do efeito do endividamento público sobre a taxa de crescimento econômico, nem a taxa de reversão que ficou em torno de $59 \%$ do PIB para o crescimento anual e de $54 \%$ para o crescimento de cinco anos. 
Por fim, outra variável que seria relevante analisarmos são os passivos contingentes dos países emergentes, pois estes podem ter efeitos significativos sobre o endividamento público que não tenham nenhuma relação com outras variáveis. Entretanto, não possuímos uma base de dados com estas variáveis para adicionarmos à nossa regressão.

\subsubsection{Endividamento e investimento público}

Como apontado em Fincke e Grainer (2015), para países emergentes existe um "caminho de transição", onde a enorme demanda por investimentos em infraestrutura acaba por resultar em uma correlação positiva entre endividamento e crescimento.

Neste sentido, temos regras fiscais que buscam preservar o investimento público. Um exemplo é a regra de ouro existente no Brasil que proíbe que o Estado emita dívida para financiar gasto corrente. Na sua forma de cálculo, o investimento público facilita a o cumprimento da regra de ouro. Portanto, como apresentado em Ministério da Economia (2020), a regra de ouro privilegia o investimento público, visando privilegiar as gerações futuras, para que estas não tenham que arcar com os custos impostos pela geração atual.

Para testarmos esta hipótese, primeiro obtivemos os dados de investimentos públicos por meio de FMI (2017b) que é uma base de dados que busca compilar os dados de investimento e estoque de capital do governo geral seguindo as metodologias Gupta et al. (2014) e Kamps (2006). Os valores que colocaremos em nossos modelos são os do investimento público em \% do $\mathrm{PIB}^{59}$. Tendo estes valores, primeiramente fizemos a regressão para o crescimento de um ano e de cinco anos inserindo o investimento público no lugar do investimento total e outras duas regressões inserindo o investimento público conjuntamente ao investimento total. Como resultado, o investimento público não se mostrou estatisticamente significante em nenhum dos casos, enquanto as variáveis de

\footnotetext{
${ }^{59}$ É importante destacar que esta base de dados possui valores para o investimento público até 2015, portanto perdemos dois anos de nossa amostra ao inserimos suas variáveis em nossos modelos.
} 
endividamento continuaram com o mesmos sinais e ponto de reversão praticamente igual.

Posteriormente, criamos uma variável dummy que assume valor igual a 1 caso o investimento público de um país em um ano específico estivesse acima da média dos países emergentes, que é de aproximadamente $4,8 \%$ do PIB, para todo nosso período de amostra. Com isso, a função a ser estimada pelo Método Generalizado de Momentos com o uso de variáveis instrumentais por um painel de efeitos fixos é dada por:

$$
\begin{aligned}
g_{i t+k}=\beta_{0}+ & \beta_{1} \text { dívida }_{i t}+\beta_{2} \text { dívida }_{i, t}^{2} \\
& +\beta_{3} \text { dívida }_{i, t} * \text { DummyInvPub } \\
& +\beta_{3, t} \ln \left(\beta_{4} \text { dívida }_{i, t}^{2} * \text { DummyInvPub }_{i, t}\right. \\
& +\varepsilon_{i t}
\end{aligned}
$$

Em comparação ao nosso modelo de estimação original, a diferença é que temos uma interação entre a dummy de investimento público alto e as variáveis de endividamento linear e de endividamento ao quadrado. Abaixo, apresentamos o resultado da nossa regressão para o crescimento de um e cinco anos à frente. 
Tabela 29: Estimação com interação de dummy de investimentos

\begin{tabular}{|c|c|c|}
\hline Variáveis & Estimação 1y & Estimação 5y \\
\hline Dívida & $\begin{array}{l}0,1473467^{*} \\
(0,0821002)\end{array}$ & $\begin{array}{c}0,8387636^{\star * *} \\
(0,2357746)\end{array}$ \\
\hline Dívida ao quadrado & $\begin{array}{l}-0,0015156^{*} \\
(0,0008369)\end{array}$ & $\begin{array}{c}-0,0087973^{* * *} \\
(0,002382)\end{array}$ \\
\hline Dívida*Dummy & $\begin{array}{l}-0,1678424^{*} \\
(0,0903712)\end{array}$ & $\begin{array}{l}-0,5140884^{\star *} \\
(0,2523175)\end{array}$ \\
\hline Dívida ao quadrado*Dummy & $\begin{array}{l}0,0034727^{\star *} \\
(0,0016554)\end{array}$ & $\begin{array}{l}0,0116967^{\star \star} \\
(0,0048798)\end{array}$ \\
\hline Ln (PIB Per Capita em PPP) & $\begin{array}{c}-3,606715^{\star \star \star} \\
(1,330555)\end{array}$ & $\begin{array}{l}-6,496073 \\
(7,553322)\end{array}$ \\
\hline Investimento & $\begin{array}{c}0,0784044 \\
(0,0535661)\end{array}$ & $\begin{array}{c}0,7234608^{\star \star *} \\
(0,213176)\end{array}$ \\
\hline Crescimento Populacional & $\begin{array}{l}-0,5161796^{\star *} \\
(0,2156331)\end{array}$ & $\begin{array}{l}-1,24966^{* * *} \\
(0,3178129)\end{array}$ \\
\hline Resultado Primário & $\begin{array}{c}0,0179649 \\
(0,0516678)\end{array}$ & $\begin{array}{c}0,1581621 \\
(0,2407854)\end{array}$ \\
\hline Abertura Comercial & $\begin{array}{l}0,0347235^{\star *} \\
(0,0141297)\end{array}$ & $\begin{array}{c}0,0909154 \\
(0,0599765)\end{array}$ \\
\hline Inflação & $\begin{array}{l}-0,0948393^{\star *} \\
(0,0465304)\end{array}$ & $\begin{array}{l}-0,2371609 \\
(0,1632674)\end{array}$ \\
\hline Crise bancária & $\begin{array}{l}-0,6384176 \\
(0,9696391)\end{array}$ & $\begin{array}{l}-6,176421^{\star * \star} \\
(2,075909)\end{array}$ \\
\hline Crise Cambial & $\begin{array}{l}-5,28149^{\star \star \star} \\
(1,217016)\end{array}$ & $\begin{array}{l}-6,977323^{\star *} \\
(3,005617)\end{array}$ \\
\hline Crise de Dívida Soberana & $\begin{array}{l}-4,817962^{* *} \\
(2,377691)\end{array}$ & $\begin{array}{c}-12,39994^{* * *} \\
(4,807015)\end{array}$ \\
\hline Crescimento Global & $\begin{array}{l}2,339415 \\
(1,662833)\end{array}$ & $\begin{array}{c}0,4914045 \\
(0,5447153)\end{array}$ \\
\hline Dummies de Ano & Sim & Sim \\
\hline Número de Observações & 692 & 584 \\
\hline$R^{2}$ Centrado & 0,3424 & 0,3116 \\
\hline Teste F & 9,84 & 15,28 \\
\hline $\begin{array}{c}\text { P-valor do Kleibergen-Paap LM } \\
\text { estat. }\end{array}$ & 0,0000 & 0,0001 \\
\hline $\begin{array}{c}\text { P-valor Sanderson-Windmeijer F } \\
\text { teste }\end{array}$ & 0,0000 & 0,0000 \\
\hline Kleibergen-Paap Wald F estat. & 5,10 & 4,43 \\
\hline
\end{tabular}

Fonte: Elaboração própria

Nota: Os valores com $\left(^{*}\right)$ indicam que rejeitamos a hipótese nula a 10\%, valores com $\left(^{* *}\right)$ indicam que rejeitamos a hipótese nula a $5 \%$, valores com ${ }^{* * *}$ indicam que rejeitamos a hipótese nula a 1\%. Erro-padrão em ().

O resultado acima mostra que, para os casos de investimento público baixo, os resultados de não linearidade se mantêm para os crescimentos um ano e cinco anos à frente, sendo que o ponto de reversão se encontra em torno de $48,6 \%$ e $47,7 \%$ do PIB, respectivamente, próximos aos valores encontrados anteriormente. Entretanto, quando analisamos para o caso dos países com 
investimento público elevado, os resultados para o endividamento são estatisticamente diferentes em comparação ao dos países de investimento público baixo, sendo que o efeito final para o caso do investimento público elevado é que mais endividamento leva a maior crescimento, tanto para o crescimento de um ano quanto de cinco anos à frente.

Um ponto de preocupação nestes resultados é o fato de que apesar de rejeitarmos a hipótese de instrumento fraco, o valor do teste de Kleibergen-Paap Wald $\mathrm{F}$ é baixo, apesar de não termos um valor crítico para comparar na tabela de Stock e Yogo (2005) para quatro variáveis instrumentadas e quatro instrumentos. Outro ponto é que, na seleção da nossa dummy, alguns países se destacam por terem investimento público elevado em todos os períodos, como Angola, China, Índia e Malásia, portanto o resultado pode estar sendo causado pelos países específicos e não pelo efeito do investimento público em si, pois como observado anteriormente o investimento público não teve efeito sobre 0 crescimento econômico ${ }^{60}$.

Por fim, realizando esta mesma estimação, mas alterando a variável dummy de investimento público elevado para variação do estoque de capital público elevado ${ }^{61}$, os resultados mostraram que a interação da dívida com a variável dummy não é estatisticamente relevante.

\subsection{Robustez}

Para verificarmos a robustez dos nossos resultados, iremos adotar uma série de exercícios de robustez na tentativa de garantir que os resultados obtidos, tanto de não linearidade quanto do ponto de reversão, se mantêm.

\subsubsection{Remoção de outliers da amostra}

Como temos um conjunto restrito de países sendo analisados, pode acontecer que a exclusão de algum destes países leve a alterações significativas

\footnotetext{
${ }^{60}$ Também colocamos o investimento público em \% do PIB como variável de interação no modelo e não obtivemos um resultado estatisticamente significante.

${ }^{61}$ A utilização da variação do estoque de capital público é uma forma de tentar obter o investimento líquido, isto é, o investimento público descontado da depreciação do capital.
} 
nos resultados obtidos. Para verificarmos quão robustos são nossos resultados com relação a heterogeneidade dos países que possuímos, iremos verificar como a exclusão de alguns outliers, isto é, países com maior ou menor média de endividamento pode alterar os resultados obtidos. Abaixo, apresentamos 0 resultado: 
Tabela 30: Estimação excluindo os outliers para crescimento anual

\begin{tabular}{|c|c|c|c|c|c|c|}
\hline Variáveis & Egito & EAU & Egito e EAU & $\begin{array}{l}\text { Egito e Sri } \\
\text { Lanka }\end{array}$ & $\begin{array}{c}\text { EAU e } \\
\text { Azerbaijão }\end{array}$ & $\begin{array}{c}\text { Egito, Sri } \\
\text { Lanka, EAU e } \\
\text { Azerbaijão }\end{array}$ \\
\hline Dívida & $\begin{array}{l}0,135675^{\star *} \\
(0,05921)\end{array}$ & $\begin{array}{l}0,1228859^{\star *} \\
(0,0546893)\end{array}$ & $\begin{array}{l}0,1191202^{\star *} \\
(0,0555385)\end{array}$ & $\begin{array}{l}0,0917758 \\
(0,0594666)\end{array}$ & $\begin{array}{c}0,1932787^{\star \star \star} \\
(0,0572465)\end{array}$ & $\begin{array}{l}0,140334^{\star \star} \\
(0,0551609)\end{array}$ \\
\hline Dívida ao quadrado & $\begin{array}{r}-0,0012021^{* *} \\
(0,0005517)\end{array}$ & $\begin{array}{r}-0,0010933^{\star *} \\
(0,0005066)\end{array}$ & $\begin{array}{l}-0,0010604^{* *} \\
(0,0005169)\end{array}$ & $\begin{array}{l}-0,0008014 \\
(0,0005499)\end{array}$ & $\begin{array}{c}-0,0018058^{* * *} \\
(0,0005279)\end{array}$ & $\begin{array}{l}-0,00133^{* * *} \\
(0,0005065)\end{array}$ \\
\hline Dummies de Ano & Sim & Sim & Sim & Sim & Sim & Sim \\
\hline Número de Observações & 709 & 711 & 693 & 682 & 689 & 644 \\
\hline$R^{2}$ Centrado & 0,4246 & 0,4299 & 0,4381 & 0,4517 & 0,3936 & 0,4482 \\
\hline Teste F & 13,65 & 13,77 & 13,77 & 13,86 & 13,34 & 13,95 \\
\hline $\begin{array}{c}\text { P-valor do Kleibergen-Paap } \\
\text { LM estat. }\end{array}$ & 0,000 & 0,000 & 0,000 & 0,000 & 0,000 & 0,000 \\
\hline $\begin{array}{l}\text { P-valor Sanderson-Windmeijer } \\
\text { F teste }\end{array}$ & 0,000 & 0,000 & 0,000 & 0,000 & 0,000 & 0,000 \\
\hline Kleibergen-Paap Wald F estat. & 12,29 & 12,46 & 11,89 & 11,24 & 10,99 & 9,96 \\
\hline Ponto de Reversão & 56,4 & 58,9 & 56,2 & 57,2 & 53,5 & 52,8 \\
\hline
\end{tabular}

Nota: Os valores com $\left(^{*}\right)$ indicam que rejeitamos a hipótese nula a 10\%, valores com $\left(^{\star *}\right)$ indicam que rejeitamos a hipótese nula a $5 \%$, valores com $\left(^{* \star *}\right)$ indicam que rejeitamos a hipótese nula a $1 \%$. Erro-padrão em (). 
Fazendo a média de endividamento dos países, chegamos que os que possuíam o maior endividamento eram Egito e Sri Lanka, com médias de 82,3\% e $79,1 \%$ do PIB, respectivamente. Enquanto aqueles que possuíam as menores médias eram Emirados Árabes Unidos (EAU) e Azerbaijão, com médias de $12,0 \%$ e $13,3 \%$ do PIB, respectivamente.

Os resultados das regressões nos mostram que, com exceção do resultado que exclui os dois países com maior endividamento, todos os outros ${ }^{62}$ se mostraram estatisticamente significantes, além de apresentarem resultados mais significantes do que aqueles observados na amostra completa. Outro ponto interessante é que o ponto de máximo do endividamento sobre o crescimento econômico se mostrou bem estável, ficando dentro do intervalo de $50-60 \%$ do PIB.

Por fim, assim como observamos no resultado para a amostra completa, a exclusão de alguns países não alterou a validade observada nos instrumentos utilizados.

Abaixo, apresentamos os resultados com a exclusão dos mesmos outliers para o crescimento acumulado de cinco anos:

\footnotetext{
${ }^{62}$ Pela ordem, fizemos a exclusão daquele com maior endividamento, depois daquele com menor endividamento, posteriormente o com maior e menor endividamentos, os dois de maior endividamento, os dois de menor endividamento e, por fim, a exclusão dos dois maiores e os dois menores endividamentos.
} 
Tabela 31: Estimação excluindo os outliers para crescimento de cinco anos

\begin{tabular}{|c|c|c|c|c|c|c|}
\hline Variáveis & Egito & EAU & Egito e EAU & $\begin{array}{l}\text { Egito e Sri } \\
\text { Lanka }\end{array}$ & $\begin{array}{c}\text { EAU e } \\
\text { Azerbaijão }\end{array}$ & $\begin{array}{c}\text { Egito, Sri } \\
\text { Lanka, EAU e } \\
\text { Azerbaijão }\end{array}$ \\
\hline Dívida & $\begin{array}{c}0,8828459^{\star * *} \\
(0,2728804)\end{array}$ & $\begin{array}{c}0,8455413^{\star \star \star} \\
(0,2629272)\end{array}$ & $\begin{array}{c}0,8437071^{\star * *} \\
(0,26373)\end{array}$ & $\begin{array}{c}0,8232339^{* \star \star} \\
(0,2920857)\end{array}$ & $\begin{array}{c}0,9829577^{\star \star \star} \\
(0,2577334)\end{array}$ & $\begin{array}{c}0,8912272^{* * *} \\
(0,2637922)\end{array}$ \\
\hline Dívida ao quadrado & $\begin{array}{c}-0,0084282^{* * *} \\
(0,0026047)\end{array}$ & $\begin{array}{c}-0,0080462^{* * *} \\
(0,0024693)\end{array}$ & $\begin{array}{c}-0,0080586^{* * *} \\
(0,0025062)\end{array}$ & $\begin{array}{c}-0,0079064^{* * *} \\
(0,0027177)\end{array}$ & $\begin{array}{c}-0,0095254^{* * *} \\
(0,0025044)\end{array}$ & $\begin{array}{c}-0,0087608^{* * *} \\
(0,0025337)\end{array}$ \\
\hline Dummies de Ano & Sim & Sim & Sim & Sim & Sim & Sim \\
\hline Número de Observações & 570 & 572 & 558 & 547 & 555 & 518 \\
\hline$R^{2}$ Centrado & 0,4126 & 0,4336 & 0,4332 & 0,4305 & 0,3600 & 0,4072 \\
\hline Teste F & 8,66 & 8,74 & 8,60 & 8,73 & 10,29 & 10,42 \\
\hline $\begin{array}{c}\text { P-valor do Kleibergen-Paap } \\
\text { LM estat. }\end{array}$ & 0,000 & 0,000 & 0,000 & 0,000 & 0,000 & 0,000 \\
\hline $\begin{array}{c}\text { P-valor Sanderson-Windmeijer } \\
\text { F teste }\end{array}$ & 0,000 & 0,000 & 0,000 & 0,000 & 0,000 & 0,000 \\
\hline Kleibergen-Paap Wald F estat. & 9,748 & 9,65 & 9,21 & 8,79 & 9,02 & 8,11 \\
\hline Ponto de Reversão & 52,4 & 52,5 & 52,3 & 52,1 & 51,6 & 50,9 \\
\hline
\end{tabular}

Nota: Os valores com $\left({ }^{\star}\right)$ indicam que rejeitamos a hipótese nula a $10 \%$, valores com $\left.{ }^{* *}\right)$ indicam que rejeitamos a hipótese nula a $5 \%$, valores com $\left(^{\star * \star}\right)$ indicam que rejeitamos a hipótese nula a $1 \%$. Erro-padrão em (). 
Assim como aconteceu para o crescimento anual, no caso do crescimento para cinco anos a exclusão dos outliers não alterou nosso resultado final, tanto em termos de significância dos coeficientes, que se mostraram mais significantes em todos os casos (inclusive no de maiores endividamentos, quando não foram significantes), quanto em termos de do ponto de reversão do efeito do endividamento, que continua se situando em torno de $50-60 \%$ do PIB.

\subsubsection{Forma polinomial da função de endividamento}

Em adição a utilização da forma quadrática do endividamento, testamos para outras possíveis funções polinomiais. No lugar da função quadrática, fizemos a regressão com polinômios a partir de 1,2, crescendo 0,2 em cada regressão até o polinômio de grau 3. Como resultado, observamos que o coeficiente do endividamento linear e 0 do endividamento polinomial continuaram estatisticamente significantes e com os sinais adequados, além do endividamento máximo oscilar entre $50-63 \%$ do PIB para o crescimento anual e entre $45-60 \%$ do PIB para o crescimento de cinco anos, dependendo da forma polinomial utilizada, sendo que quanto menor o polinômio, menor o nível máximo de endividamento.

Adicionamos o formato cúbico, em adição ao formato linear e quadrático para verificarmos se esta relação poderia assumir o formato cúbico. Como resultado, verificamos que os coeficientes não se mostraram estatisticamente significantes para o crescimento anual e o crescimento de cinco anos.

Por fim, construímos intervalos de confiança para o ponto de reversão na estimação por efeito fixo que possui um ponto de reversão de 56\% do PIB para o crescimento anual e de $53 \%$ do PIB para o crescimento de cinco anos. Como nosso ponto de reversão é formado por uma combinação não linear, a distribuição normal com intervalo de confiança a 95\% estimada para cada coeficiente não pode ser utilizada para obter o intervalo de confiança para estes pontos. Para resolvermos este problema, calculamos o ponto de reversão por meio do método Delta e obtivemos como resultado que a $95 \%$ de confiança o ponto de reversão se situa entre $43 \%$ e $70 \%$ do PIB para o crescimento de um ano e entre $43 \%$ e $62 \%$ do PIB para o crescimento de cinco anos. Portanto, este 
intervalo continua sendo inferior ao ponto de reversão encontrado para países desenvolvidos.

\subsubsection{Crescimento de 10 anos e crescimento de 5 anos sem sobreposição}

Um dos fatores que podem influenciar os resultados é o tamanho do período de crescimento utilizado. Conforme observamos, para o crescimento anual (curto prazo) e de cinco anos (médio prazo) os resultados se mantêm, sendo que para o crescimento de cinco anos os resultados são ainda mais robustos. Para verificarmos uma métrica que pode indicar o crescimento de longo prazo, utilizaremos o crescimento de 10 anos.

Os resultados apontam que o endividamento apresentou um nível de significância sobre o crescimento econômico ainda maior que aquele observado para o crescimento de cinco anos, com o ponto de reversão em torno de $61 \%$ do PIB.

Para o crescimento de cinco anos, utilizamos na nossa estimação principal o crescimento com sobreposição, isto é, o crescimento do período seguinte carregaria informação dos quatro anos anteriores. Para lidarmos com isso, corrigimos para os problemas de autocorrelação que teríamos no termo de erro.

Para garantirmos que nossos resultados são robustos, fizemos a regressão para o crescimento de cinco anos sem o problema de sobreposição. Entretanto, ao fazermos isso, temos o problema de eficiência, pois perdemos em torno de 4/5 das observações. Como resultado, observamos que nossos resultados se mantem sobre o efeito do endividamento sobre o crescimento econômico com ponto de reversão em torno de 50\% do PIB.

\subsubsection{Persistência do crescimento e variação da dívida}

Outro fator que pode alterar o nosso resultado principal é a possível persistência na taxa de crescimento do produto, isto é, que o crescimento do ano anterior possua algum tipo de influência sobre o crescimento do ano corrente. 
Como mostrando em BCE (2010), este fenômeno conhecido como carry-over effect tem bastante importância na taxa de crescimento anual dos países.

Levando este fenômeno em consideração, fizemos abaixo a regressão para o crescimento anual e o crescimento de cinco anos ${ }^{63}$ para o painel com efeitos fixos pelo GMM com variáveis instrumentais, controlando para heterocedasticidade e autocorrelação.

63 Para o caso do crescimento de cinco anos, não é possível acreditar que uma possível persistência tenha relação com o carry-over effect, pois verificaremos como o crescimento de cinco anos atrás teria efeito sobre o acumulado de cinco anos à frente, de forma que não haja sobreposição entre os intervalos, logo esta herança estatística se dissiparia ao longo do período. 
Tabela 32: Estimação com persistência no crescimento

\begin{tabular}{|c|c|c|}
\hline Variáveis & Estimação 1y & Estimação 5y \\
\hline Dívida & $\begin{array}{l}0,1242909^{*} \\
(0,0715851)\end{array}$ & $\begin{array}{l}0,4224364^{* *} \\
(0,1990275)\end{array}$ \\
\hline Dívida ao quadrado & $\begin{aligned}-0,0010277^{*} \\
(0,000606)\end{aligned}$ & $\begin{array}{c}-0,0045785^{\star \star *} \\
(0,0016847)\end{array}$ \\
\hline Taxa de Crescimento Passada & $\begin{array}{l}0,2956446^{\star \star *} \\
(0,0801358)\end{array}$ & $\begin{array}{l}-0,1831576^{\star \star} \\
(0,0781227)\end{array}$ \\
\hline Ln (PIB Per Capita em PPP) & $\begin{array}{l}-4,537100^{* \star *} \\
(1,125389)\end{array}$ & $\begin{array}{l}-16,10194^{\star *} \\
(6,861427)\end{array}$ \\
\hline Investimento & $\begin{array}{c}0,0526244 \\
(0,0455037)\end{array}$ & $\begin{array}{l}0,8722103^{* * *} \\
(0,1775291)\end{array}$ \\
\hline Crescimento Populacional & $\begin{array}{l}-0,2733293 \\
(0,1730061)\end{array}$ & $\begin{array}{l}-1,012626^{\star * \star} \\
(0,3593122)\end{array}$ \\
\hline Resultado Primário & $\begin{array}{l}0,0386622 \\
(0,047662)\end{array}$ & $\begin{array}{l}-0,308553 \\
(0,264982)\end{array}$ \\
\hline Abertura Comercial & $\begin{array}{l}0,0198786^{*} \\
(0,0112176)\end{array}$ & $\begin{array}{c}-0,048146 \\
(0,0504925)\end{array}$ \\
\hline Inflação & $\begin{array}{l}-0,0074449 \\
(0,0164171)\end{array}$ & $\begin{array}{c}0,0606805 \\
(0,0466582)\end{array}$ \\
\hline Crise bancária & $\begin{array}{l}-0,2257497 \\
(0,9818043)\end{array}$ & $\begin{array}{l}-6,357718^{* * *} \\
(1,928089)\end{array}$ \\
\hline Crise Cambial & $\begin{array}{l}-4,535649^{\star * \star} \\
(1,202615)\end{array}$ & $\begin{array}{l}-10,45484^{\star \star \star} \\
(2,524746)\end{array}$ \\
\hline Crise de Dívida Soberana & $\begin{array}{c}-3,729760^{* * *} \\
(2,553123)\end{array}$ & $\begin{array}{l}-1,314825 \\
(3,392094)\end{array}$ \\
\hline Crescimento Global & $\begin{array}{l}0,8655019^{*} \\
(0,4977065)\end{array}$ & $\begin{array}{r}-1,314825 \\
(3,39094) \\
\end{array}$ \\
\hline Dummies de Ano & Sim & Sim \\
\hline Número de Observações & 724 & 532 \\
\hline$R^{2}$ Centrado & 0,4757 & 0,6249 \\
\hline Teste $\mathrm{F}$ & 12,47 & 13,80 \\
\hline $\begin{array}{l}\text { P-valor do Kleibergen-Paap LM } \\
\text { estat. }\end{array}$ & 0,0000 & 0,0000 \\
\hline $\begin{array}{c}\text { P-valor Sanderson-Windmeijer F } \\
\text { teste }\end{array}$ & 0,0000 & 0,0000 \\
\hline Kleibergen-Paap Wald F estat. & 9,87 & 12,67 \\
\hline
\end{tabular}

Fonte: Elaboração própria

Nota: Os valores com $\left({ }^{*}\right)$ indicam que rejeitamos a hipótese nula a $10 \%$, valores com $\left({ }^{* *}\right)$ indicam que rejeitamos a hipótese nula a $5 \%$, valores com $\left.{ }^{* * *}\right)$ indicam que rejeitamos a hipótese nula a 1\%. Erro-padrão em ().

Os resultados acima mostram que a hipótese de persistência é válida, isto é, o crescimento passado possui uma relação sobre o crescimento futuro, ainda que para o caso do crescimento um ano à frente este efeito seja positivo, enquanto para o crescimento cinco anos à frente o efeito seja negativo, indicando que há uma reversão à média para este período de crescimento. Além disso, a adição desta variável não alterou os resultados para a relação não linear do endividamento para casos do crescimento anual e o crescimento em cinco anos, 
sendo que o ponto de reversão se situa em torno de $60 \%$ do PIB e $63 \%$ do PIB, respectivamente.

Como observado em todas as estimações anteriores, o nível do endividamento possui efeito sobre o crescimento econômico para diferentes períodos de crescimento. Uma importante alteração seria verificar se além do nível, a variação no endividamento explicaria o crescimento econômico. Portanto, alteramos a variável explicativa do nível do endividamento para a variação do endividamento e, como consequência, alteramos o instrumento, passando-o de nível para a variação. Como resultado, não encontramos efeito estatisticamente significante da variação do endividamento sobre o crescimento econômico nem para o crescimento de um ano quanto para o crescimento de cinco anos à frente ${ }^{64}$. Portanto, apenas o nível do endividamento possui efeito sobre o crescimento e não sua variação, dado que esta teria a mesma interpretação para diferentes níveis de endividamento, portanto teria diferentes efeitos dependendo do nível de endividamento que o país está.

\subsection{Conclusão}

O endividamento público é a principal forma que os países possuem de financiar seus déficits orçamentários e, após a crise financeira, o Brasil e outros países emergentes tiveram uma deterioração significativa em seus níveis de endividamento.

O endividamento pode apresentar diversos efeitos sobre importantes variáveis macroeconômicas, como taxa de juros e investimento, tendo, como consequência, efeitos sobre a taxa de crescimento econômico do país. Portanto, dada a possibilidade deste efeito sobre o crescimento, este ensaio buscou investigar se, para um grupo de países emergentes, este efeito é estatisticamente significante e se ele é não linear, como encontrado em alguns artigos da literatura, mas não corroborado em outros. Entretanto, um problema nesta abordagem é que, assim como o endividamento pode ter efeito sobre o crescimento, este também afeta o endividamento, ou ainda, uma terceira variável

\footnotetext{
${ }^{64}$ Esta não significância estatística se repete quando fazemos a regressão por meio de um painel de efeitos fixos sem a utilização de variáveis instrumentais.
} 
pode afetar ambos. Para lidar com este problema e conseguir estimar o efeito do endividamento sobre o crescimento, fizemos uso do método de variáveis instrumentais.

Como metodologia, utilizamos a estimação via Métodos Generalizados de Momentos com variáveis instrumentais, sendo que o instrumento utilizado foi a média do endividamento de outros países, seguindo o instrumento proposto por Checherita-Westphal e Rotter (2012). Neste caso, nosso trabalho se diferenciou dos outros para países emergentes por levarmos em consideração o problema de endogenidade e utilizarmos variáveis instrumentais para tratá-lo, além de utilizarmos o endividamento interno, enquanto a maioria dos trabalhos focou no endividamento externo.

Como resultado, encontramos evidências de não linearidade entre crescimento e endividamento no formato de $U$ invertido, sendo que este ponto fica entre $40-60 \%$ do PIB. Quando fazemos os intervalos de confiança a 95\% pelo método Delta, o ponto de reversão se situa entre $40-70 \%$ do PIB. Tanto para as diferentes metodologias quanto para o intervalo de confiança, o ponto de reversão é significativamente inferior ao encontrado para países desenvolvidos, que se situa entre $70-100 \%$ do PIB. Estes resultados são válidos tanto para o crescimento anual, que seria o crescimento de curto prazo, quanto para o crescimento de cinco anos, que seria o crescimento de médio prazo. Além disso, os testes apontaram que os instrumentos utilizados não sofrem com os problemas de subidentificação ou de instrumento fraco.

Os resultados se mostraram robustos à heterocedasticidade e autocorrelação; à exclusão dos países de maior e menor endividamento; à adição do crédito privado como proxy para o endividamento privado e da variável de democracia; para a persistência do crescimento (crescimento defasado) como variável de controle; à mudanças do polinômio do endividamento que entra em conjunto com o endividamento linear; e a um período de crescimento de 10 anos. Já para a dívida externa, soma da dívida externa pública e privada, não encontramos evidências desta não linearidade, assim como não encontramos significância no efeito da variação do endividamento sobre o crescimento econômico. 
Por fim, realizamos uma novo exercício de estimação que teve como resultado que países com maior nível de democracia possuem ponto de reversão em níveis superiores de endividamento em comparação com países com menor nível de democracia. Em outro exercício que busca diferenciar o efeito do endividamento sobre o crescimento econômico para investimento público alto e baixo, encontramos para os casos em que o investimento público é baixo, que os resultados de não linearidade e do ponto de reversão se mantiveram, mas para os casos em que o investimento público é alto, encontramos que maior endividamento leva a maior crescimento. Entretanto, é importante ponderar que o resultado pode estar relacionado aos países que historicamente possuem investimento público alto e acabam sendo maioria nas dummies e não ao fato do investimento público levar a maior crescimento, pois quando utilizada no controle ela não teve efeito sobre crescimento. Além disso, para outra métrica de investimento público, a variação do estoque de capital, o resultado não foi corroborado. 


\section{Conclusão}

Como apresentado na introdução desta tese, houve deterioração nas finanças públicas nos países emergentes após a crise de 2009, em especial, uma significativa piora nos resultados primários do Brasil. Devido a isso, buscamos ao longo dos três ensaios que compõe esta tese verificar como os resultados de impulso fiscal para o Brasil se alteram conforme utilizamos distintas metodologias e diferentes formas de medir o produto potencial; verificar a existência de fadiga fiscal e estimar o nível máximo de endividamento para um grupo de países emergentes seguindo a metodologia proposta por Ghosh et al. (2013); estimar o efeito do endividamento público sobre o crescimento econômico e se este efeito é não linear, utilizando um painel com variáveis instrumentais para um conjunto de países emergentes.

Para o ensaio em que medimos o impulso fiscal por diferentes metodologias, encontramos que estas diferentes metodologias apresentam resultados pouco diferentes, com exceção da metodologia antiga utilizada pela OCDE. Entretanto, quando alteramos a forma de medir o produto potencial, há uma diferença significativa para alguns anos. Além disso, mostramos como os resultados de impulso fiscal diferem significativamente da simples diferença do resultado primário, indicando importância da utilização desta métrica ajustada para a correta avaliação da política fiscal. Por fim, observamos que a deterioração recente das contas públicas brasileira está associada a uma política fiscal expansionista, sendo que nos últimos dois anos de análise (2017 e 2018) houve uma mudança com impulsos fiscais contracionistas.

Para o ensaio sobre fadiga fiscal e limite de endividamento, encontramos que a hipótese de fadiga fiscal foi confirmada e corroborada por diversos testes de robustez. Ela se inicia para níveis de endividamento em torno de $70 \%$ do PIB, enquanto a resposta marginal ao aumento do endividamento se torna negativa em torno de $110 \%$ do PIB. Estes resultados são significativamente inferiores aos observados em países desenvolvidos, mesmo quando levamos em consideração os intervalos de confiança. Para obtermos o limite de endividamento, combinamos o resultado estimado para a função de reação fiscal e o diferencial entre taxa de juros e crescimento econômico na média de 11 anos 
(2006 a 2016). Para o caso determinista, os resultados indicaram níveis de endividamento máximo inferiores aos observados para países desenvolvidos, e com média em torno de $154,1 \%$ do PIB, bem acima do nível médio atual de $47,8 \%$ do PIB. Mesmo individualmente, o espaço fiscal é elevado, inclusive para países que possuem o menor espaço fiscal da amostra. Entretanto, para o caso estocástico, há uma redução significativa no limite de dívida e no espaço fiscal. Ainda que para a maioria dos países a situação fiscal continue pouco preocupante, para Brasil e Croácia em especial o espaço fiscal é baixo, indicando a necessidade destes países realizarem ajustes nos próximos anos que possibilitem a redução no seu nível de endividamento. Estes resultados são corroborados para outras métricas de cálculo de juros e crescimento econômico.

Por fim, para o ensaio que procura medir o efeito do endividamento público sobre o crescimento econômico, temos que há evidências de não linearidade entre crescimento e endividamento no formato de $U$ invertido, sendo que este ponto fica entre $40-60 \%$ do PIB. Quando fazemos os intervalos de confiança a $95 \%$ pelo método Delta, o ponto de reversão se situa entre $40-70 \%$ do PIB. Tanto para as diferentes metodologias quanto para o intervalo de confiança, o ponto de reversão é significativamente inferior ao encontrado para países desenvolvidos, que se situa entre $70-100 \%$ do PIB, sendo estes resultados válidos para os crescimentos de um e cinco anos à frente. Os resultados se mostraram robustos a uma série de testes de robustez realizados. Por fim, realizamos uma análise que teve como resultado que países com maior nível de democracia possuem ponto de reversão em níveis superiores de endividamento em comparação com países com menor nível de democracia. Em outro exercício que busca diferenciar o efeito do endividamento sobre 0 crescimento econômico para investimento público alto e baixo, encontramos para os casos em que o investimento público é baixo, que os resultados de não linearidade e do ponto de reversão se mantiveram, mas para os casos em que o investimento público é alto, encontramos que maior endividamento leva a maior crescimento. 


\section{Bibliografia}

AFONSO, A.; ALVES, J. The role of government debt in economic growth. ISEGUTL Economics Department Working Paper, n. 16, 2014.

ANDERSON, T. Estimating linear restrictions on regression coefficients for multivariate normal distributions. The Annals of Mathematical Statistics, v. 22, n. 3, p. 327-351, 1951.

ANGRIST, J.; PISCHKE, J. Mostly harmless econometrics: An empiricist's companion. Princeton university press, 2008.

ARELLANO, M.; BOND, S. Some tests of specification for panel data: Monte Carlo evidence and an application to employment equations. The review of economic studies. v. 58, n. 2, p. 277-297, 1991.

ARELLANO, M.; BOVER, O. Another look at the instrumental variable estimation of error-components models. Journal of econometrics, v. 68, n. 1, p. 29-51, 1995.

BAI, J.; PERRON, P. Estimating and testing linear models with multiple structural changes. Econometrica. p. 47-78, 1998.

BANCO CENTRAL DO BRASIL. Impulso Fiscal. Relatório de Inflação 2011 (Junho). v. 13, n. 2, p. $37-40,2011$.

BANCO CENTRAL DO BRASIL. Política Fiscal. Notas econômico-financeiras para a imprensa. Brasília, Dezembro de 2016.

BANCO CENTRAL EUROPEU. The carry-over effect on annual average real GDP growth. ECB Monthly Bulletin. Março de 2010.

BANCO MUNDIAL. World Bank Open Data. Washington, 2018.

BANCO MUNDIAL. World Bank Open Data. Washington, 2019. 
BANERJEE, A; DOLADO,J.; GALBRAITH, J.; HENDRY, D. Co-integration, Error Correction, and Econometric Analysis of Non-Stacionary Data. OUP Catalogue. 1993

BARRO, R. On the determination of the public debt. Journal of political Economy, v. 87, n. 5, Part 1, p. 940-971, 1979.

BAUM, A; CHECHERITA - WESTPHAL, C.; ROTHER, P. Debt and Growth: New Evidence for the Euro Area. Journal of International Money and Finance. V. 32, p. $809-821,2013$.

BERNANKE, Ben; GERTLER, Mark. Financial fragility and economic performance. The Quarterly Journal of Economics, v. 105, n. 1, p. 87-114, 1990.

BERTI, K.; COLESNIC E.; DESPONTS, C.; PAMIES, S.; SAIL, E. Fiscal Reaction Functions for European Countries. European Comission Discussion Paper. $\mathrm{n}^{\circ}$ $28,2016$.

BEVILAQUA, A.; WERNECK, R. Fiscal impulse in the Brazilian economy, 19891996. Texto para discussão - PUC-Rio, 1997.

BI, H.; LEEPER, E. Analyzing fiscal sustainability. Bank of Canada Working Paper, 2013.

BI, H.; SHEN, W.; YANG, S.. Fiscal limits in developing countries: A DSGE Approach. Journal of Macroeconomics, v. 49, p. 119-130, 2016.

BLANCHARD, O. Suggestions for a New Set of Fiscal Indicators. OECD Working Paper. N. 79, Paris, 1990.

BOHN, H. The behavior of US public debt and deficits. The Quarterly Journal of economics. V. 113, n. 3, p. 949-963, 1998.

BORNHORST, F.; DOBRESCU, G.; FEDELINO, A.; GOTTSCHALK, J.; NAKATA, T. When and how to adjust beyond the business cycle? A guide to structural fiscal balances. IMF Technical Notes and Manuals, v. 11, n. 02, 2011. 
BROCHADO, A.; BARBOSA, F.; LEISTER, M.; MARCOS, R.; MOTA, T.; SBARDELOTTO, T; ARAÚJO, V. Regras fiscais: uma proposta de arcabouço sistêmico para o caso brasileiro. Textos para discussão do Tesouro Nacional. 2019.

CAMURI, P. Endividamento público e crescimento econômico: evidências teóricas e empíricas para economias desenvolvidas e emergentes. 2015. Tese de Doutorado. Universidade Federal de Minas Gerais - CEDEPLAR, Minas Gerais, 2015.

CANER, M.; GRENNES, T.; KOEHLER-GEIB, F. Finding the tipping point: when sovereign debt turns bad. Sovereign Debt and Financial Crisis, p. 64-75, 2010.

CARLIN, W.; SOSKICE, D. Macroeconomics: Institutions, instability, and the financial system. Oxford University Press, USA, 2014.

CARVALHO, L.; MEDEIROS, O.; SILVA, A. Dívida Pública: a experiência brasileira. Banco Mundial, 2009.

CAVALCANTI, T.; MOHADDES, K.; RAISSI, M. Commodity Price Volatility and the Sources of Growth. Journal of Applied Econometrics. 2014

CECCHETTI, S.; MOHANTY, M.; ZAMPOLLI, F. Achieving growth amid fiscal imbalances: the real effects of debt. In: Economic Symposium Conference Proceedings. Federal Reserve Bank of Kansas City, p. 145-196, $2011 \mathrm{a}$.

CECCHETTI, S.; MOHANTY, M.; ZAMPOLLI, F. The Real Effects of Debt. BIS Working Papers. No. 352, $2011 \mathrm{~b}$.

CELASUN, O.; OSTRY, J.; DEBRUN, X. Primary surplus behavior and risks to fiscal sustainability in emerging market countries: A "Fan-chart" approach. IMF Staff Papers. v. 53, n. 3, p. 401-425, 2006.

CHAND, S. Summary measures of fiscal influence. Staff Papers, v. 24, n. 2, p. 405-449, 1977.

CHAND, S. Fiscal impulse measures and their fiscal impact. How to Measure the Fiscal Deficit: Analytical and Methodological Issues, p. 55-99, 1993. 
CHECHERITA-WESTPHAL, C.; ROTHER, P. The impact of high government debt on economic growth and its channels: An empirical investigation for the euro area. European economic review, v. 56, n. 7, p. 1392-1405, 2012.

CHECHERITA-WESTPHAL, C.; ŽĎÁREK, V. Fiscal reaction function and fiscal fatigue: evidence for the euro area. ECB Working Paper, 2017.

CHICOLI, R. Sustentabilidade da dívida pública brasileira: Uma análise sob diversos conceitos de superávit primário e endividamento. 87 p. Dissertação de Mestrado. Universidade de São Paulo, São Paulo, 2015.

CHOURAQUI, J; JONES, B.; MONTADOR, R. Public debt in a medium-term context and its implications for fiscal policy. OECD Publishing, 1986.

CHUDIK, A.; MOHADDES, K; PESARAN, M; RAISSI, M. Is there a debtthreshold effect on output growth? Review of Economics and Statistics, v. 99, n. 1, p. 135-150, 2017.

COCHRANE, J. Understanding policy in the great recession: Some unpleasant fiscal arithmetic. European Economic Review, v. 55, n. 1, p. 2-30, 2011.

CODOGNO, L.; FAVERO, C.; MISSALE, A. Yield spreads on EMU government bonds. Economic Policy, v. 18, n. 37, p. 503-532, 2003.

COHEN, D. Growth and external debt: A new perspective on the African and Latin American tragedies. London: Centre for Economic Policy Research, 1997.

COLLIER, P.; GODERIS, B. Commodity Prices and Growth: An Empirical Investigation. European Economic Review. vol. 56, p. 1241-1260, 2012.

COSTANTINI, O. The cyclically adjusted budget: history and exegesis of a fateful estimate. Institute for New Economic Thinking Working Paper. n. 24, 2015.

DAUDE, C.; MELGUIZO, A.; NEUT, A. Fiscal policy in Latin America: countercyclical and sustainable at last? Economics: The Open-Access, OpenAssessment E-Journal, v. 5, n. 2011-14, p. 1-29, 2011. 
DEATON, A.; MILLER, R. International Commodity Prices, Macroeconomic Performance and Politics in Sub-Saharan Africa. Journal of African Economies. v. 5, n. 3, p. 99-191, 1996.

DE LEEUW, F. e HOLLOWAY, T. The high-employment budget: revised estimates and automatic inflation effects. Survey of Current Business. n. 62, 1982.

D'ERASMO, P., MENDOZA, E., ZHANG, J. "What is a sustainable debt?" NBER Working Paper. no 21574, 2015.

DEHN, J. The Effects on Growth of Commodity Price Uncertainty and Shocks. World Bank Policy Research Working Paper. n. 2455, 2000.

DERNBURG, Thomas F. Fiscal analysis in the Federal Republic of Germany: the cyclically neutral budget. Staff Papers, v. 22, n. 3, p. 825-857, 1975.

DIAMOND, P. National debt in a neoclassical growth model. The American Economic Review, v. 55, n. 5, p. 1126-1150, 1965.

DICKEY, D.; PANTULA, S. Determining the order of differencing in autoregressive processes. Journal of Business \& Economic Statistics, v. 5, n. 4, p. 455-461, 1987.

DYSON, K. States, Debt, and Power: 'saints' and 'sinners' in European History and Integration. OUP Oxford, 2014.

EBERHARDT, M.; PRESBITERO, A. Public debt and growth: Heterogeneity and non-linearity. Journal of International Economics, v. 97, n. 1, p. 45-58, 2015.

ELBADAWI, I.; NDULU, B.; NDUNG'U, N. Debt overhang and economic growth in Sub-Saharan Africa. External finance for low-income countries, p. 49-76, 1997.

ESCOLANO, F. A practical guide to public debt dynamics, fiscal sustainability, and cyclical adjustment of budgetary aggregates. Washington: Fiscal Affairs Department. 28 p., 2010. 
ESCOLANO, J.; SHABUnINA, A ; WOO, J.The Puzzle of Persistently Negative Interest Rate-Growth Differentials: Financial Repression or Income Catch-Up? International Monetary Fund, 2011.

EVERAERT, G.; JANSEN, S. On the Estimation of Panel Fiscal Reaction Functions: Heterogeneity or Fiscal Fatigue? Economic Modeling. p. 1-10, 2017.

FALL, F; FOURNIER, J. Limits to government debt sustainability. OECD Economics Department Working Papers. N. 1229, $2015 a$.

FALL, F.; FOURNIER, J. Macroeconomic uncertainties, prudent debt targets and fiscal rules. OECD Economics Department Working Papers. N. 1230, 2015b.

FEDELINO, A, IVANOVA, A, HORTON, M. Computing cyclically adjusted balances and automatic stabilizers. Washington: Fiscal Affairs Department. 15 p., 2009

FERNANDES, C. Ensaios sobre política fiscal: perspectivas histórica, teórica e empírica. 2015. Tese (Doutorado em Economia das Instituições e do Desenvolvimento) - Faculdade de Economia, Administração e Contabilidade, Universidade de São Paulo, São Paulo, 2015.

FINCKE, B.; GREINER, A. Public debt and economic growth in emerging market economies. South African Journal of Economics, v. 83, n. 3, p. 357-370, 2015.

FUNDO MONETÁRIO INTERNACIONAL. World Economic Outlook. Washington, 2003.

FUNDO MONETÁRIO INTERNACIONAL. Tackling Inequality. Fiscal Monitor. Washington, 2017a.

FUNDO MONETÁRIO INTERNACIONAL. IMF Investment and Capital Stock Dataset. Washington, 2017b.

FUNDO MONETÁRIO INTERNACIONAL. World Economic Outlook. Washington, 2018.

FUNDO MONETÁRIO INTERNACIONAL. World Economic Outlook. Washington, 2019. 
GARCIA, M.; RIGOBON, R. A risk management approach to emerging market's sovereign debt sustainability with an application to Brazilian data. NBER. Working Paper n. 10336, 2004.

GHOSH, A.; KIM, J.; MENDOZA, E.; OSTRY, J.; QURESHI, M. Fiscal fatigue, fiscal space and debt sustainability in advanced economies. The Economic Journal, v. 123, n. 566, 2013.

GOBETTI, S.; GOUVEAA, R.; SCHETTINI, B. Resultado fiscal estrutural: um passo para a institucionalização de políticas anticíclicas no Brasil. Texto para Discussão, Instituto de Pesquisa Econômica Aplicada. n. 1515, 2010.

GOBETTI, S.; ORAIR, R.; DUTRA, F. Resultado Estrutural, Ciclos Econômicos, e os Desafios para Avaliar o Desempenho Fiscal. Prêmio Tesouro Nacional. Brasília, 2017.

GUPTA, S.; KANGUR, A.; PAPAGEORGIOU, C.; WANE, A. Efficiency-adjusted public capital and growth. World Development, v. 57, p. 164-178, 2014.

HELLER, P., HASS, R., MANSUR, A. A Review of the Fiscal Impulse Measure. Occasional Paper. International Monetary Fund. n.44, 1986.

HERNDON, T.; ASH, M.; POLLIN, R. Does high public debt consistently stifle economic growth? A critique of Reinhart and Rogoff. Cambridge Journal of Economics, v. 38, n. 2, p. 257-279, 2014.

HOLE, A. A comparison of approaches to estimating confidence intervals for willingness to pay measures. Health Economics, v. 16, n. 8, p. 827-840, 2007.

INSTITUTO FISCAL INDEPENDENTE (IFI). Resultado Estrutural. Relatório de Acompanhamento Fiscal 2017 (Março). n. 2, 2017.

JOUMARD, I.; MINEGISHI, M.; ANDRÉ, C.; NICQ, C. PRICE, R. Accounting for one-off operations when assessing underlying fiscal positions. 2008.

JUDSON, R.; OWEN, A. Estimating dynamic panel data models: a guide for macroeconomists. Economics letters. v. 65, n. 1, p. 9-15, 1999.

KAMPS, C. New estimates of government net capital stocks for 22 OECD countries, 1960-2001. IMF staff papers, v. 53, n. 1, p. 120-150, 2006. 
KLEIBERGEN, F.; PAAP, R. Generalized reduced rank tests using the singular value decomposition. Journal of econometrics, v. 133, n. 1, p. 97-126, 2006.

KOURTELLOS, A.; STENGOS, T.; TAN, C. The effect of public debt on growth in multiple regimes. Journal of Macroeconomics, v. 38, p. 35-43, 2013.

KRUGMAN, P. R.; OBSTFELD, M.; MELITZ, M. International economics: Trade and policy. 2015.

KUMAR, M.; WOO, J. Public Debt and Growth. IMF Working Paper. No. 10/174, 2010.

LAEVEN, L.; VALENCIA, F. Systemic banking crises revisited. International Monetary Fund, 2018.

LAUBACH, T. New evidence on the interest rate effects of budget deficits and debt. Journal of the European Economic Association, v. 7, n. 4, p. 858-885, 2009.

MACIEL, P. Proposta à regra fiscal brasileira: orientação pelos ciclos econômicos. Brasília: ESAF, 2006. 32p. Monografia premiada em $2^{\circ}$ lugar no XI PrêmioTesouro Nacional - 2006, Qualidade do Gasto Público, Brasília (DF).

MEDEIROS, J.2012. Stochastic debt simulation using VAR models and a panel fiscal reaction function - results for a selected number of countries. European Economy - Economic Papers 2008 - 2015. Directorate General Economic and Financial Affairs (DG ECFIN), European Commission, n. 459, 2012.

MENDOZA, E.; OSTRY, J. International evidence on fiscal solvency: Is fiscal policy "responsible"?. Journal of Monetary Economics. v. 55, n. 6, p. 10811093, 2008.

MENDOZA, E. G.; OVIEDO, P. M. Public Debt, Fiscal Solvency and Macroeconomic Uncertainty in Latin America. Economía mexicana nueva época, v.18, n.2, 2009.

MINISTÉRIO DA ECONOMIA. Secretaria do Tesouro Nacional. Relatório Quadrimestral de Projeções da Dívida Pública. Brasília, 2019. 
MINISTÉRIO DA ECONOMIA. Secretaria do Tesouro Nacional. De onde vem o desequilíbrio da regra de ouro. Brasília, 2020.

NORTH, D.; WEINGAST, B. Constitutions and commitment: the evolution of institutions governing public choice in seventeenth-century England. The journal of economic history, v. 49, n. 4, p. 803-832, 1989.

ORENG, M. Superávit fiscal estrutural brasileiro. Texto para Discussão, n. 6 , São Paulo: Itaú, 2011.

ORGANIZAÇÃO PARA A COOPERAÇÃO E DESENVOLVIMENTO ECONÔMICO (OCDE). Economic Outlook, 1983.

PANIZZA, U. Domestic and external public debt in developing countries. In: United Nations Conference on Trade and Development Discussion Paper. 2008.

PANIZZA, U.; PRESBITERO, A. Public debt and economic growth: is there a causal effect? Journal of Macroeconomics, v. 41, p. 21-41, 2014.

PATILLO, C.; POIRSON, Helene; RICCI, Luca Antonio. External debt and growth. International Monetary Fund, 2002.

PEREIRA, R. $\mathrm{O}$ ajuste cíclico dos gastos públicos federais brasileiros. Texto para Discussão, Instituto de Pesquisa Econômica Aplicada. n. 632, 27p., 1999.

PHILIP, R.; JANSSEN, J. Indicators of fiscal impulse for New Zealand. New Zealand Treasury, Treasury Working Paper Series, v. 2, p. 30, 2002.

REINHART, C.; ROGOFF, K.; SAVASTANO, M. Debt intolerance. Brookings Papers on Economic Activity, v. 1, p. 1-74, 2003.

REINHART, C.; ROGOFF, K. Growth in a Time of Debt. American Economic Review. V. 100, n. 2, p. 573-78, 2010.

REINHART, C.; ROGOFF, K. From financial crash to debt crisis. American Economic Review, v. 101, n. 5, p. 1676-1706, 2011.

REINHART, Carmen. The Return of Financial Repression. CEPR Discussion Papers, 2012. 
RIBEIRO, L. Sobre arrecadação e atividade econômica. Nota Técnica - Ibre. 2016.

SAEED, S.; ISLAM, T. Public Debt and Economic Growth Nexus: Evidence from South Asia. Prepints. 2018.

SAINT-PAUL, G. Fiscal policy in an endogenous growth model. The Quarterly Journal of Economics, v. 107, n. 4, p. 1243-1259, 1992.

SALSMAN, R. The political economy of public debt: three centuries of theory and evidence. Edward Elgar Publishing, 2017.

SANDERSON, Eleanor; WINDMEIJER, Frank. A weak instrument F-test in linear IV models with multiple endogenous variables. Journal of Econometrics, v. 190, n. 2, p. 212-221, 2016.

SARGENT, T.; WALLACE, N. Some unpleasant monetarist arithmetic. Federal Reserv Bank of Minneapolis. Quarterly Review. v. 5, n. 3, p. 1-17, 1981.

SCHCLAREK, A. Debt and economic growth in developing and industrial countries. Lund University Department of Economics Working Paper, v. 2005, p. 34, 2004.

SCHETTINI, B., GOBETTI, S., GOUVÊA, R., ORAIR, R. Resultado estrutural e impulso fiscal: Uma aplicaçãopara as administrações públicas no Brasil, 1997-2010. Texto para Discussão, Instituto de Pesquisa Econômica Aplicada. n. 1650, 2011.

SCHINASI, G. J.; LUTZ, M. S. Fiscal impulses. IMF Working Paper, Washington, WP/91/91, 1991

SIDAOUI, J. Implications of Fiscal Issues for Central Banks: Mexico's Experience. BIS Papers. n. 20, 2003.

SECRETARIA DE POLÍTICA ECONÔMICA (SPE). Nota Metodológica Resultado Fiscal Estrutural. Ministério da Fazenda, Brasília, 2018.

SEGURA-UBIERGO, A. The puzzle of Brazil's high interest rates. International Monetary Fund, 2012. 
SMYTH, D.; HSING, Y. In search of an optimal debt ratio for economic growth. Contemporary Economic Policy, v. 13, n. 4, p. 51-59, 1995.

SOUZA-JÚNIOR, J. R. C.; CAETANO, S. M. Produto potencial como ferramenta de análise da política monetária e da capacidade de crescimento da economia brasileira. Revista EconomiA. v. 14, n. 1C, p. 671-702, 2013.

SOUZA-JÚNIOR, J. R. C. Impacto da nova metodologia do sistema de contas nacionais sobre as estimativas de produtividade e do produto potencial. Carta de Conjuntura do Ipea. v. 27, p. 125-134, 2015.

STAIGER, D., STOCK, J. Instrumental Variables Regression with Weak Instruments. Econometrica. 65(3), 557-586, 1997.

STOCK, J.; WATSON, M. A Simple Estimator of Cointegration Vectors in High Order Integrated Systems. Econometrica. v. 61, p. 783-820, 1993.

STOCK, J.; YOGO, M. Testing for Weak Instruments in Linear IV Regression. In: Andrews DWK Identification and Inference for Econometric Models. New York: Cambridge University Press, pp. 80-108, 2005.

TESOURO NACIONAL. Relatório Fiscal do Tesouro Nacional de 2017. Brasília, 2018

TANZI, V.; CHALK, N. Impact of large public debt on growth in the EU: A discussion of potential channels. European Economy, v. 2, n. 2000, p. 23-43, 2000.

TRAN, N. Debt Threshold for Fscal Sustainability Assessment in Emerging Economies. Journal of Policy Modeling. 2018

VDOVYCHENKO, A. Estimating the Fiscal Impulse in Ukraine. Visnyk of the National Bank of Ukraine, n. 245, p. 45-63, 2018.

WOOLDRIDGE, Jeffrey M. Introductory econometrics: A modern approach. Nelson Education, 2016. 
ANEXO 


\section{A.1. Derivação do Limite de dívida para o caso estocástico}

\section{A.1.1. Probabilidade de default dado o limite de dívida}

Em qualquer período, a probabilidade de default do governo no período seguinte é dada por:

$$
\begin{aligned}
& p_{t+1}=\operatorname{pr}\left(d_{t+1}>\bar{d}\right)=\operatorname{pr}\left(\varepsilon_{t+1}<H_{t}\right)=G\left(H_{t}\right) \\
& \text { Em que } H_{t}=\left(r_{t}-g\right) d_{t}-\mu-f\left(d_{t}\right)-\left(\bar{d}-d_{t}\right) \text {. A condição de }
\end{aligned}
$$
arbitragem (5) pode ser reescrita como:

$$
1+r_{t}=\left(1+r^{*}\right)\left(\frac{1-\theta p_{t+1}}{1-p_{t+1}}\right)
$$

Combinando (A.1) e (A.2) para obter a probabilidade de default (para um dado $\bar{d}$ ) como a solução do problema de ponto fixo:

$$
p=z(p ; d, \bar{d})
$$

Em que

$$
\begin{gathered}
z(p ; d, \bar{d})=\left\{\begin{array}{lr}
0 & \text { se } H(p ; d, \bar{d}) \leq-\bar{\varepsilon} \\
1 & \text { se } H(p ; d, \bar{d})>\bar{\varepsilon} \\
G[H(p ; d, \bar{d})] & \text { caso contrário }
\end{array}\right. \\
H(p ; d, \bar{d})=\left[\left(r^{*}-g\right) d-\mu-f(d)\right]-(\bar{d}-d)+(1-\theta)\left(1+r^{*}\right) d\left[\frac{p}{1-p}\right]
\end{gathered}
$$

Há, ao menos, uma solução de canto para (A.3) dada por $p=1$. Podem existir múltiplas soluções interiores, mas pela Hipótese III, garantimos que há um único equilíbrio dado pela menor solução interior.

\section{A.1.2. Fronteiras no limite de dívida}

Vamos apresentar os limites inferiores e superiores. O limite superior, $\bar{d}_{2}$, é dado implicitamente pela maior raiz de:

$$
\mu+f\left(\bar{d}_{2}\right)+\bar{\varepsilon}=\left(r^{*}-g\right) \bar{d}_{2}
$$


O lado esquerdo de (A.4) é o maior superávit primário possível de se obter para o limite $\bar{d}_{2}$ na realização do choque. O lado direito é o mínimo pagamento de juros para $\bar{d}_{2}$. Além de $\bar{d}_{2}$, mesmo com o choque estocástico, não é possível controlar o crescimento do endividamento.

Para o limite inferior, dado implicitamente pela maior raiz de:

$$
\mu+f\left(\bar{d}_{1}\right)+\bar{\varepsilon}=\left(r^{*}-g\right) \bar{d}_{1}
$$

O lado esquerdo de (A.5) é o menor superávit primário possível de se obter para o limite $\bar{d}_{1}$ na realização do choque, e este superávit é suficiente para arcar com o pagamento de juros quando os credores mudam a taxa de juros livre de risco. Como a dívida é não crescente pata todas as realizações do choque, não há risco de default.

\section{A.1.3. Limite de dívida}

Para determinar $\bar{d}$, com as fronteiras estabelecidas acima, há um nível $\hat{d}<\bar{d}$ que corresponde ao máximo de endividamento que garante a solução de canto para $p=0 \mathrm{em}$ (A.3). Portanto, $\hat{d}$ garante que o governo estará apto a pagar no próximo período, e o intervalo de endividamento $(\hat{d}, \bar{d})$ é onde há negociação de dívida com risco de default.

Quando a dívida fica acima de $\hat{d}$, o mercado embute um prêmio de risco e a solução interior de (A.3) determina a probabilidade de equilíbrio de default e a taxa de juros. A solução interior é dada por $p^{*}=p^{*}(d, \bar{d}) \epsilon(0,1)$. Além disso, o limite de dívida deve ser superior a $\hat{d}$ se $p^{*}$ existe. Assumindo que ele exista, ele deve apresentar as seguintes propriedades:

$$
\frac{\partial p^{*}}{\partial d}>0 e \frac{\partial p^{*}}{\partial \bar{d}}<0
$$

Estes resultados indicam que a probabilidade aumenta quando aumenta o nível atual de endividamento, mas diminui quando o limite de dívida aumenta.

O limite de dívida deve satisfazer estas duas condições de equilíbrio simultaneamente: 
(i) $p^{*}$ deve existir para $d \in(\hat{d}, d)$

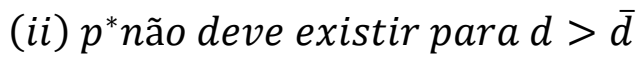

A primeira condição implica que sempre que a dívida permanecer abaixo ou no limite, sempre haverá emprestadores neutros ao risco dispostos a financiá-la por um prêmio de risco finito. A segunda condição implica que $p=1$ deve ser a única solução se a dívida ultrapassar seu limite. Neste caso, não há prêmio de risco elevado suficiente que compense o risco de default. Com isso, a taxa de juros exigida pelos emprestadores é infinita, a dívida entra em trajetória explosiva e o governo decreta o default.

Denotando a solução interior de equilíbrio como $d=\bar{d}$ por $\bar{p}^{*}=$ $p^{*}(\bar{d}, \bar{d})$, condição (ii) em (A.7) conjuntamente com o primeiro resultado em (A.6), implica que $\bar{p}^{*}$ deve ser a máxima solução interior.

Formalmente, se requer:

(i) $\bar{p}^{*}=\bar{z}\left(\bar{p}^{*}\right)$

(ii) $\partial \bar{z}(p) /\left.\partial p\right|_{p^{*}}=1$

Em que $\bar{z}(p)=z(p ; \bar{d}, \bar{d})$ por conveniência. 


\section{A.2. Limite de endividamento com juros de mercado}

Pelo modelo utilizado neste trabalho, a taxa de juros é uma variável crucial para a determinação do endividamento máximo dos países, dado que a combinação entre diferencial de crescimento e taxa de juros com a função de reação fiscal é o que impõe o limite de endividamento para os países.

Dada a importância desta métrica, é essencial garantirmos que os resultados obtidos sejam estáveis para diferentes métricas de taxa de juros, dado que há diversas formas de obter esta variável. Neste anexo, optamos por utilizar a taxa básica de juros dos países e calculamos qual seria o limite de endividamento de cada um deles utilizando tanto a metodologia de média quanto a do juro estrutural e produto potencial.

Abaixo, colocamos o diferencial entre taxa de juros e crescimento econômico para os países da nossa amostra completa para o período de 11 anos $(2006 \text { a } 2016)^{65}$ :

${ }^{65}$ Para Angola, conseguimos obter, apenas os dados de 2011 a 2016; Cazaquistão e Paquistão, só temos os dados de 2015 e 2016, logo optamos por não apresentar o valor; República Dominicana, Emirados Árabes Unidos, Equador e México, temos dados de 2008 a 2016; Indonésia só temos o dado de 2016; Omã de 2007 a 2016; Para Rússia, temos apenas de 2013 a 2016, logo decidimos não apresentar o resultado; Turquia temos, apenas, os dados de 2010 a 2016. 
Tabela 33: Diferencial entre taxa de juros básica e crescimento econômico pelo método da média (em \%)

\begin{tabular}{cc}
\hline País & $\begin{array}{c}\text { Diferencial entre taxa de jurus e } \\
\text { crescimento econômico }\end{array}$ \\
\hline África do Sul & $-2,216$ \\
Argélia & $-4,306$ \\
Azerbaijão & $-13,13$ \\
Brasil & 1,352 \\
Colômbia & $-3,219$ \\
Croácia & 4,368 \\
República Dominicana & $-3,675$ \\
Emirados Árabes Unidos & $-3,165$ \\
Equador & $-7,382$ \\
Filipinas & $-4,304$ \\
Hungria & 1,234 \\
México & $-1,634$ \\
Marrocos & $-2,689$ \\
Omã & $-5,301$ \\
Peru & $-5,391$ \\
Polônia & $-2,428$ \\
Romênia & $-3,569$ \\
Turquia & $-7,926$ \\
Uruguai & $-4,662$ \\
\hline
\end{tabular}

Fonte: FMI e Bloomberg. Elaboração própria

Assim como em nossa análise original, diversos países apresentam diferencial negativo, mostrando que este resultado independe da métrica de juros utilizada.

Abaixo, apresentamos os resultados para o limite máximo de endividamento para o caso determinístico: 
Tabela 34: Espaço Fiscal e Limite de Endividamento para o caso determinista pelo método da média (em \% do PIB)

\begin{tabular}{ccccc}
\hline País & Dívida Atual $^{\mathrm{a}}$ & Espaço Fiscal & $\begin{array}{c}\text { Limite de } \\
\text { Endividamento }\end{array}$ & $\begin{array}{c}\text { Intervalo de } \\
\text { Endividamento }\end{array}$ \\
\hline África do Sul & 51,6 & 106,5 & 158,1 & $(154,5 ; 162,2)$ \\
Argélia & 20,4 & 147,1 & 167,5 & $(156,8 ; 179,5)$ \\
Azerbaijão & 50,7 & 124,1 & 174,8 & $(151,6 ; 189,9)$ \\
Brasil & 78,4 & 59,7 & 138,1 & $(129,9 ; 147,5)$ \\
Colômbia & 49,8 & 106,2 & 156,0 & $(151,3 ; 158,6)$ \\
Croácia & 82,3 & 51,7 & 134,0 & $(119,4 ; 146,1)$ \\
República & 34,6 & 132,7 & 167,3 & $(165,0 ; 169,2)$ \\
Dominicana & & & & \\
Emirados & 20,2 & 106,2 & 126,4 & $(-; 159,9)$ \\
Árabes Unidos & 43,2 & 131,2 & 174,4 & $(162,8 ; 180,7)$ \\
Equador & 39,0 & 134,5 & 173,5 & $(171,4 ; 175,8)$ \\
Filipinas & 76,0 & 67,2 & 143,2 & $(138,7 ; 150,8)$ \\
Hungria & 56,8 & 104,7 & 161,5 & $(157,1 ; 166,0)$ \\
México & 64,9 & 94,3 & 159,2 & $(155,1 ; 162,1)$ \\
Marrocos & 32,5 & 130,5 & 163,0 & $(133,2 ; 176,0)$ \\
Omã & 24,5 & 141,7 & 166,2 & $(161,5 ; 169,0)$ \\
Peru & 54,2 & 87,7 & 141,9 & $(138,3 ; 145,5)$ \\
Polônia & 38,8 & 112,3 & 151,1 & $(140,2 ; 162,2)$ \\
Romênia & 28,3 & 139,9 & 168,2 & $(163,1 ; 171,9)$ \\
Turquia & 61,6 & 104,4 & 166,0 & $(163,9 ; 170,1)$ \\
Uruguai & 47,8 & 109,6 & 157,4 & $(150,8 ; 165,4)$ \\
Média & 49,8 & 111,7 & 161,5 & $(154,8 ; 166,0)$ \\
Mediana & & & &
\end{tabular}

Fonte: FMI. Elaboração própria

a: Dívida bruta observado no ano de 2016

Como é possível observar acima, tanto os valores da média quanto da mediana apresentaram valores muito semelhantes ao observado para nossa métrica original de cálculo de diferencial entre taxa de juros e crescimento econômico, assim como para os intervalos de endividamento que levam em consideração o $25^{\circ}$ e $75^{\circ}$ percentil para o diferencial entre endividamento e crescimento econômico.

Abaixo, observamos os valores para o caso estocástico: 
Tabela 35: Espaço Fiscal e Limite de Endividamento para o caso estocástico pelo método da média (em \% do PIB)

\begin{tabular}{|c|c|c|c|c|}
\hline País & Dívida Atuala $^{a}$ & Espaço Fiscal & $\begin{array}{c}\text { Limite de } \\
\text { Endividamento }\end{array}$ & $\begin{array}{c}\text { Intervalo de } \\
\text { Endividamento }\end{array}$ \\
\hline África do Sul & 51,6 & 78,2 & 129,8 & $(126,2 ; 133,4)$ \\
\hline Argélia & 20,4 & 111,0 & 131,4 & $(121,6 ; 142,2)$ \\
\hline Azerbaijão & 50,7 & 81,4 & 132,2 & $(117,3 ; 145,9)$ \\
\hline Brasil & 78,4 & 39,9 & 118,3 & $(109,1 ; 132,2)$ \\
\hline Colômbia & 49,8 & 71,9 & 121,7 & $(115,2 ; 124,2)$ \\
\hline Croácia & 82,3 & 16,6 & 98,9 & $(90,5 ; 113,0)$ \\
\hline $\begin{array}{l}\text { República } \\
\text { Dominicana }\end{array}$ & 34,6 & 109,2 & 143,8 & $(142,0 ; 145,0)$ \\
\hline $\begin{array}{c}\text { Emirados } \\
\text { Árabes } \\
\text { Unidos }\end{array}$ & 20,2 & - & - & $(-;-)$ \\
\hline Equador & 43,2 & 106,3 & 149,5 & $(141,3 ; 153,7)$ \\
\hline Filipinas & 39,0 & 115,2 & 154,2 & $(150,9 ; 153,8)$ \\
\hline Hungria & 76,0 & 40,8 & 116,8 & $(124,2 ; 141,4)$ \\
\hline México & 56,8 & 81,1 & 137,9 & $(134,7 ; 141,1)$ \\
\hline Marrocos & 64,9 & 66,2 & 131,1 & $(127,4 ; 133,6)$ \\
\hline Omã & 32,5 & 97,1 & 129,6 & $(-; 140,3)$ \\
\hline Peru & 24,5 & 123,5 & 148,0 & $(144,8 ; 149,8)$ \\
\hline Polônia & 54,2 & 81,1 & 135,3 & $(133,1 ; 137,7)$ \\
\hline Romênia & 38,8 & 82,3 & 121,1 & $(129,5 ; 132,4)$ \\
\hline Turquia & 28,3 & 108,2 & 136,5 & $(132,1 ; 139,7)$ \\
\hline Uruguai & 61,6 & 64,7 & 126,3 & $(139,0 ; 132,0)$ \\
\hline Média & 47,8 & 81,6 & 130,9 & $(128,2 ; 138,4)$ \\
\hline Mediana & 49,8 & 81,3 & 131,3 & $(129,5 ; 140,0)$ \\
\hline
\end{tabular}

Fonte: FMI. Elaboração própria

a: Dívida bruta observado no ano de 2016

Assim como no caso determinístico, o caso estocástico não apresentou muita alteração em relação aos valores de média e mediana. O que se destaca é que se observou uma melhora para o caso do Brasil, enquanto para a Croácia houve uma redução significativa em seu espaço fiscal. Além destes, a Hungria teve uma piora ficando com espaço fiscal inferior a 50\% de dívida/PIB. Quando analisamos os intervalos de endividamento, percebemos que para 0 caso da Croácia a situação se torna muito preocupante em um contexto em que

\footnotetext{
${ }^{66}$ Assim como no caso estocástico anterior, não foi possível obter o limite de dívida para os Emirados Árabes Unidos.
} 
o diferencial se torne muito elevado, podendo ser causado por uma redução na taxa de crescimento ou aumento na taxa de juros.

Abaixo, apresentamos o diferencial entre juros e crescimento pela metodologia de juros estrutural e crescimento potencial.

Tabela 36: Diferencial entre taxa de juros básica e crescimento econômico pelo método de juros estrutural e crescimento potencial (em \%)

\begin{tabular}{cc}
\hline País & $\begin{array}{c}\text { Diferencial entre taxa de jurus e } \\
\text { crescimento econômico }\end{array}$ \\
\hline África do Sul & $-2,216$ \\
Argélia & $-4,306$ \\
Azerbaijão & $-13,13$ \\
Brasil & 1,352 \\
Colômbia & $-3,219$ \\
Croácia & 4,368 \\
República Dominicana & $-3,675$ \\
Emirados Árabes Unidos & $-3,165$ \\
Equador & $-7,382$ \\
Filipinas & $-4,304$ \\
Hungria & 1,234 \\
México & $-1,634$ \\
Marrocos & $-2,689$ \\
Omã & $-5,301$ \\
Peru & $-5,391$ \\
Polônia & $-2,428$ \\
Romênia & $-3,569$ \\
Turquia & $-7,926$ \\
Uruguai & $-4,662$ \\
\hline
\end{tabular}

Fonte: FMI e Bloomberg. Elaboração própria

É possível observar que para a maioria dos países há um aumento no diferencial em comparação à metodologia da média calculada anteriormente. Abaixo, apresentamos os resultados para o caso determinista. 
Tabela 37: Espaço Fiscal e Limite de Endividamento para o caso determinista pelo método de juros estrutural e crescimento potencial (em $\%$ do PIB)

\begin{tabular}{cccc}
\hline País & Dívida Atual & Espaço Fiscal & $\begin{array}{c}\text { Limite de } \\
\text { Endividamento }\end{array}$ \\
\hline África do Sul & 51,6 & 103,2 & 154,8 \\
Argélia & 20,4 & 147,5 & 167,9 \\
Azerbaijão & 50,7 & 117,3 & 168,0 \\
Brasil & 78,4 & 53,6 & 132,0 \\
Colômbia & 49,8 & 99,5 & 149,3 \\
Croácia & 82,3 & 59,8 & 142,1 \\
República & 34,6 & 127,9 & 162,5 \\
Dominicana & & 114,7 & 134,9 \\
Emirados Árabes & 20,2 & & 167,2 \\
Unidos & 43,2 & 124,0 & 168,7 \\
Equador & 39,0 & 129,7 & 140,0 \\
Filipinas & 76,0 & 64,0 & 159,6 \\
Hungria & 56,8 & 102,8 & 162,8 \\
México & 64,9 & 97,9 & 164,0 \\
Marrocos & 32,5 & 131,5 & 157,5 \\
Omã & 24,5 & 133,0 & 136,5 \\
Peru & 54,2 & 82,3 & 145,4 \\
Polônia & 38,8 & 106,6 & 159,9 \\
Romênia & 28,3 & 131,6 & 160,0 \\
Turquia & 61,6 & 98,4 & 154,4 \\
Uruguai & 47,8 & 106,6 & 159,6 \\
Média & 49,8 & 109,8 &
\end{tabular}

Fonte: FMI. Elaboração própria

Como esperado, há uma redução na média e mediana do limite de endividamento, devido à maioria dos países ter apresentado um aumento no diferencial entre juros e crescimento, mas não há mudanças grandes entre os países. Abaixo, apresentamos o resultado para o caso estocástico. 
Tabela 38: Espaço Fiscal e Limite de Endividamento para o caso estocástico pelo método de juros estrutural e crescimento potencial (em $\%$ do PIB)

\begin{tabular}{ccccc}
\hline País & Dívida Atual & Espaço Fiscal & $\begin{array}{c}\text { Limite de } \\
\text { Endividamento }\end{array}$ & $\begin{array}{c}\text { Intervalo de } \\
\text { Endividamento }\end{array}$ \\
\hline África do Sul & 51,6 & 75,3 & 126,9 & $(126,2 ; 133,4)$ \\
Argélia & 20,4 & 111,6 & 132,0 & $(121,6 ; 142,2)$ \\
Azerbaijão & 50,7 & 74,3 & 125,0 & $(117,3 ; 145,9)$ \\
Brasil & 78,4 & 38,3 & 116,7 & $(109,1 ; 132,2)$ \\
Colômbia & 49,8 & 62,8 & 112,6 & $(115,2 ; 124,2)$ \\
Croácia & 82,3 & 24,2 & 106,5 & $(90,5 ; 113,0)$ \\
República & 34,6 & 105,6 & 140,2 & $(142,0 ; 145,0)$ \\
Dominicana & & & & $(-;-)$ \\
Emirados & 20,2 & - & & \\
Árabes & & & & $(141,3 ; 153,7)$ \\
Unidos ${ }^{67}$ & 43,2 & 101,1 & 144,3 & $(150,9 ; 153,8)$ \\
Equador & 39,0 & 110,2 & 149,2 & $(124,2 ; 141,4)$ \\
Filipinas & 76,0 & 36,9 & 112,9 & $(134,7 ; 141,1)$ \\
Hungria & 56,8 & 79,6 & 136,4 & $(-; 140,3)$ \\
México & 64,9 & 69,1 & 134,0 & $(127,4 ; 133,6)$ \\
Marrocos & 32,5 & 98,4 & 130,9 & $(144,8 ; 149,8)$ \\
Omã & 24,5 & 117,6 & 142,1 & $(133,1 ; 137,7)$ \\
Peru & 54,2 & 78,0 & 132,2 & $(129,5 ; 132,4)$ \\
Polônia & 38,8 & 74,2 & 113,0 & $(132,1 ; 139,7)$ \\
Romênia & 28,3 & 100,7 & 129,0 & $(139,0 ; 132,0)$ \\
Turquia & 61,6 & 61,1 & 122,7 & $(128,2 ; 138,4)$ \\
Uruguai & 47,8 & 78,8 & 128,1 & $(129,5 ; 140,0)$ \\
Média & 49,8 & 76,7 & 130,0 &
\end{tabular}

Fonte: FMI. Elaboração própria

Em relação ao caso da média de 11 anos, as médias e medianas se reduziram, como esperado pelo diferencial ser maior para a maioria dos países. Analisando individualmente, há uma melhora para o caso da Croácia, que estava muito próxima do seu limite, mas uma piora para países como Brasil e Hungria, ainda que seus espaços fiscais continuem acima de $30 \%$ do PIB.

\footnotetext{
${ }^{67}$ Assim como no caso estocástico anterior, não foi possível obter o limite de dívida para os Emirados Árabes Unidos.
} 


\section{B.1. Estatísticas Descritivas}

\begin{tabular}{ccccccc}
\hline Variável & Média & Mediana & DP & Mínimo & Máximo & $\begin{array}{c}\text { Observa } \\
\text { ções }\end{array}$ \\
\hline $\begin{array}{c}\text { Crescimento PIB } \\
\text { per capita }\end{array}$ & 4,66 & 4,96 & 5,26 & $-24,45$ & 36,82 & 962 \\
Ln (PIB per capita) & 9,15 & 9,16 & 0,76 & 6,89 & 11,43 & 968 \\
Dívida & 43,93 & 41,14 & 24,59 & 2,69 & 152,25 & 758 \\
Investimento & 24,40 & 23,68 & 8,39 & $-1,5$ & 79,14 & 969 \\
Crescimento & 1,29 & 1,26 & 1,93 & $-9,43$ & 29,83 & 965 \\
Populacional & & & & & & \\
Resultado Primário & 0,41 & $-0,06$ & 4,08 & $-21,64$ & 22,02 & 823 \\
Abertura & 68,67 & 59,10 & 36,65 & 13,75 & 220,41 & 946 \\
Inflação & 62,31 & 6,53 & 473,11 & $-7,59$ & 10154,97 & 949 \\
Crise bancária & 0,03 & 0 & 0,17 & 0 & 1 & 980 \\
Crise cambial & 0,04 & 0 & 0,20 & 0 & 1 & 980 \\
Crise soberana & 0,01 & 0 & 0,11 & 0 & 1 & 980 \\
Crescimento Global & 5,97 & 5,67 & 2,44 & 0,36 & 13,88 & 980 \\
\hline
\end{tabular}




\section{B.2. Regressão para o endividamento externo}

Nossa estimativa para a dívida externa não é totalmente comparável com aquela para dívida interna pois, dos 39 países iniciais, tivemos que excluir $15^{68}$ países por não possuírem dados de endividamento ou os dados não serem confiáveis ${ }^{69}$.

Abaixo, apresentamos os resultados para a regressão do crescimento anual utilizando a dívida externa. Como é possível observar pelos resultados, a hipótese da não linearidade se confirma para a regressão por painel de efeitos fixos (1); para a regressão por variáveis instrumentais utilizando o método de GMM robusto para heterocedasticidade e autocorrelação (2); e para a regressão de painel de efeitos fixos por método de GMM para variáveis instrumentais (3).

${ }^{68}$ Excluímos os seguintes países: Argentina, Cazaquistão, Chile, Croácia, Hungria, Kuwait, Líbia, Malásia, Omã, Polônia, Qatar, Emirados Árabes Unidos, Ucrânia, Uruguai e Venezuela.

${ }^{69}$ Os dados de endividamento externo foram obtidos do Banco Mundial (2019). 
Tabela 39: Estimação da taxa de crescimento anual para o endividamento externo

\begin{tabular}{|c|c|c|c|}
\hline Variáveis & Estimação 1 & Estimação 2 & Estimação 3 \\
\hline Dívida & $\begin{array}{c}-0,021894 \\
(0,0347137)\end{array}$ & $\begin{array}{l}-0,0424808 \\
(0,0610327)\end{array}$ & $\begin{array}{c}-0,929267 \\
(0,0573796)\end{array}$ \\
\hline Dívida ao quadrado & $\begin{array}{l}0,0001294 \\
(0,0002787)\end{array}$ & $\begin{array}{l}0,0001688 \\
(0,0006283)\end{array}$ & $\begin{array}{c}0,0008082 \\
(0,0005919)\end{array}$ \\
\hline $\begin{array}{c}\text { Ln (PIB Per Capita em } \\
\text { PPP) }\end{array}$ & $\begin{array}{c}-7,027637^{* * *} \\
(1,440083)\end{array}$ & $\begin{array}{c}-2,495318^{\star * \star} \\
(0,387923)\end{array}$ & $\begin{array}{c}-3,808677^{\star * *} \\
(1,018127)\end{array}$ \\
\hline Investimento & $\begin{array}{c}-0,012864 \\
(0,0462648)\end{array}$ & $\begin{array}{c}0,0906586^{\star * *} \\
(0,0339693)\end{array}$ & $\begin{array}{c}0,0564348 \\
(0,0617618)\end{array}$ \\
\hline Crescimento & 0,136448 & $-1,39044^{* * *}$ & $-0,0033847$ \\
\hline Populacional & $(0,4793238)$ & $(0,2497468)$ & $(0,3671342)$ \\
\hline Resultado Primário & $\begin{array}{c}0,0846131 \\
(0,0576601)\end{array}$ & $\begin{array}{l}0,0998344^{* *} \\
(0,0504758)\end{array}$ & $\begin{array}{l}0,0851255 \\
(0,057423)\end{array}$ \\
\hline Abertura Comercial & $\begin{array}{l}0,067853^{\star \star \star} \\
(0,0217084)\end{array}$ & $\begin{array}{l}0,0172051^{\star} \\
(0,0093895)\end{array}$ & $\begin{array}{c}0,0504906^{\star \star *} \\
(0,0185214)\end{array}$ \\
\hline Inflação & $\begin{array}{c}0,0017977 \\
(0,0050959)\end{array}$ & $\begin{array}{c}-0,0100409^{\star * *} \\
(0,0018893)\end{array}$ & $\begin{array}{c}-0,0127172^{\star \star *} \\
(0,0019119)\end{array}$ \\
\hline Crise bancária & $\begin{array}{c}1,660545 \\
(0,9992218)\end{array}$ & $\begin{array}{c}0,3448319 \\
(0,9026563)\end{array}$ & $\begin{array}{c}0,1871208 \\
(0,9702123)\end{array}$ \\
\hline Crise Cambial & $\begin{array}{l}-2,703501^{* * *} \\
(0,7706831)\end{array}$ & $\begin{array}{c}-4,539484^{\star * *} \\
(1,089832)\end{array}$ & $\begin{array}{l}-4,12845^{\star * *} \\
(1,096674)\end{array}$ \\
\hline $\begin{array}{l}\text { Crise de Dívida } \\
\text { Soberana }\end{array}$ & $\begin{array}{l}-1,424072 \\
(1,714535)\end{array}$ & $\begin{array}{l}-1,375698 \\
(2,346998)\end{array}$ & $\begin{array}{l}-3,891906 \\
(2,965086)\end{array}$ \\
\hline Crescimento Global & $\begin{array}{c}1,071578^{*} \\
(0,5815899)\end{array}$ & $\begin{array}{l}-5,980344 \\
(10,21521)\end{array}$ & $\begin{array}{l}-18,57769 \\
(11,24775)\end{array}$ \\
\hline Constante & $\begin{array}{c}61,93071^{* \star *} \\
(8,942702)\end{array}$ & $\begin{array}{c}26,61257^{\star \star *} \\
(3,891113)\end{array}$ & \\
\hline Dummies de Ano & Sim & Sim & Sim \\
\hline $\begin{array}{l}\text { Número de } \\
\text { Observações }\end{array}$ & 505 & 529 & 529 \\
\hline$R^{2}$ & 0,2289 & 0,4782 & 0,4578 \\
\hline Teste F & 8,26 & 12,93 & 10,36 \\
\hline Coeficiente $\mathrm{AR}(1)$ & 0,353679 & & \\
\hline $\begin{array}{l}\text { P-valor do Kleibergen- } \\
\text { Paap LM estat. }\end{array}$ & & 0,0008 & 0,0000 \\
\hline $\begin{array}{l}\text { P-valor Sanderson- } \\
\text { Windmeijer F teste }\end{array}$ & & 0,0000 & 0,0000 \\
\hline $\begin{array}{c}\text { Kleibergen-Paap Wald } \\
\text { F estat. }\end{array}$ & & 7,78 & 12,97 \\
\hline
\end{tabular}

Fonte: Elaboração própria

Nota: Os valores com $\left({ }^{\star}\right)$ indicam que rejeitamos a hipótese nula a 10\%, valores com $\left(^{* *}\right)$ indicam que rejeitamos a hipótese nula a $5 \%$, valores com $\left(^{* * *}\right)$ indicam que rejeitamos a hipótese nula a 1\%. Erro-padrão em ().

Assim como aconteceu para o crescimento anual, o crescimento para cinco anos também não apresentou coeficientes significantes para os três tipos de regressões anteriores. 
Tabela 40: Estimação da taxa de crescimento de cinco anos para o endividamento externo

\begin{tabular}{|c|c|c|c|}
\hline Variáveis & Estimação 4 & Estimação 5 & Estimação 6 \\
\hline Dívida & $\begin{array}{c}-0,2109981^{* *} \\
(0,0814019)\end{array}$ & $\begin{array}{l}-0,1700191 \\
(0,3043921)\end{array}$ & $\begin{array}{l}-0,2187954 \\
(0,1748828)\end{array}$ \\
\hline Dívida ao quadrado & $\begin{array}{c}0,000586 \\
(0,0004187)\end{array}$ & $\begin{array}{l}-0,0002883 \\
(0,0029546)\end{array}$ & $\begin{array}{l}0,0018873 \\
(0,0016495)\end{array}$ \\
\hline $\begin{array}{c}\text { Ln (PIB Per Capita em } \\
\text { PPP) }\end{array}$ & $\begin{array}{c}-60,39544^{\star * \star} \\
(7,081932)\end{array}$ & $\begin{array}{c}-14,96541^{\star \star \star} \\
(2,345663)\end{array}$ & $\begin{array}{l}-8,841477 \\
(6,296056)\end{array}$ \\
\hline Investimento & $\begin{array}{c}0,396765^{\star \star \star} \\
(0,07339)\end{array}$ & $\begin{array}{c}0,8189655^{\star * *} \\
(0,2432238)\end{array}$ & $\begin{array}{c}0,8015753^{\star \star \star} \\
(0,2806247)\end{array}$ \\
\hline Crescimento & $-0,5115968$ & $-8,023815^{\star \star *}$ & $-0,6760138$ \\
\hline Populacional & $(0,5152481)$ & $(1,313749)$ & $(1,389376)$ \\
\hline Resultado Primário & $\begin{array}{c}0,0359073 \\
(0,0754981)\end{array}$ & $\begin{array}{l}0,7166228^{* *} \\
(0,3628422)\end{array}$ & $\begin{array}{c}0,1833502 \\
(0,31133409)\end{array}$ \\
\hline Abertura Comercial & $\begin{array}{c}0,0771282 \\
(0,0424966)\end{array}$ & $\begin{array}{l}0,119902^{\star *} \\
(0,0576024)\end{array}$ & $\begin{array}{l}0,1254296^{*} \\
(0,0756263)\end{array}$ \\
\hline Inflação & $\begin{array}{l}-0,0198958^{*} \\
(0,0118588)\end{array}$ & $\begin{array}{l}-0,0754379 \\
(0,0512818)\end{array}$ & $\begin{array}{c}-0,0906073^{\star \star \star} \\
(0,0281529)\end{array}$ \\
\hline Crise bancária & $\begin{array}{l}-2,288118^{*} \\
(1,174667)\end{array}$ & $\begin{array}{l}0,2574337 \\
(3,026992)\end{array}$ & $\begin{array}{l}-1,309539 \\
(1,720887)\end{array}$ \\
\hline Crise Cambial & $\begin{array}{l}-2,507801^{* \star *} \\
(0,9526269)\end{array}$ & $\begin{array}{l}-5,326359^{*} \\
(2,782456)\end{array}$ & $\begin{array}{c}-6,434935^{\star \star *} \\
(1,842998)\end{array}$ \\
\hline $\begin{array}{l}\text { Crise de Dívida } \\
\text { Soberana }\end{array}$ & $\begin{array}{l}-0,9325823 \\
(1,665894)\end{array}$ & $\begin{array}{l}0,4020518 \\
(3,917726)\end{array}$ & $\begin{array}{l}-2,070643 \\
(2,589676)\end{array}$ \\
\hline Crescimento Global & $\begin{array}{c}1,943109 \\
(1,269261)\end{array}$ & $\begin{array}{l}-0,1331055 \\
(0,4282493)\end{array}$ & $\begin{array}{c}0,2268291 \\
(0,4771957)\end{array}$ \\
\hline Constante & $\begin{array}{c}540,0428^{* * *} \\
(5,514744)\end{array}$ & $\begin{array}{c}154,015^{\star * \star} \\
(30,5501) \\
\end{array}$ & \\
\hline Dummies de Ano & Sim & Sim & Sim \\
\hline $\begin{array}{l}\text { Número de } \\
\text { Observações }\end{array}$ & 431 & 431 & 431 \\
\hline$R^{2}$ & 0,0945 & 0,5594 & 0,4933 \\
\hline Teste $\mathrm{F}$ & 13,44 & 13,53 & 11,35 \\
\hline $\begin{array}{l}\text { P-valor do Kleibergen- } \\
\text { Paap LM estat. }\end{array}$ & & 0,0029 & 0,0000 \\
\hline $\begin{array}{l}\text { P-valor Sanderson- } \\
\text { Windmeijer F teste }\end{array}$ & & 0,0000 & 0,0000 \\
\hline $\begin{array}{c}\text { Kleibergen-Paap Wald } \\
\text { F estat. }\end{array}$ & & 5,84 & 9,97 \\
\hline
\end{tabular}

Fonte: Elaboração própria

Nota: Os valores com $\left({ }^{*}\right)$ indicam que rejeitamos a hipótese nula a $10 \%$, valores com $\left(^{* *}\right)$ indicam que rejeitamos a hipótese nula a $5 \%$, valores com $\left({ }^{\star \star \star}\right)$ indicam que rejeitamos a hipótese nula a 1\%. Erro-padrão em (). 